
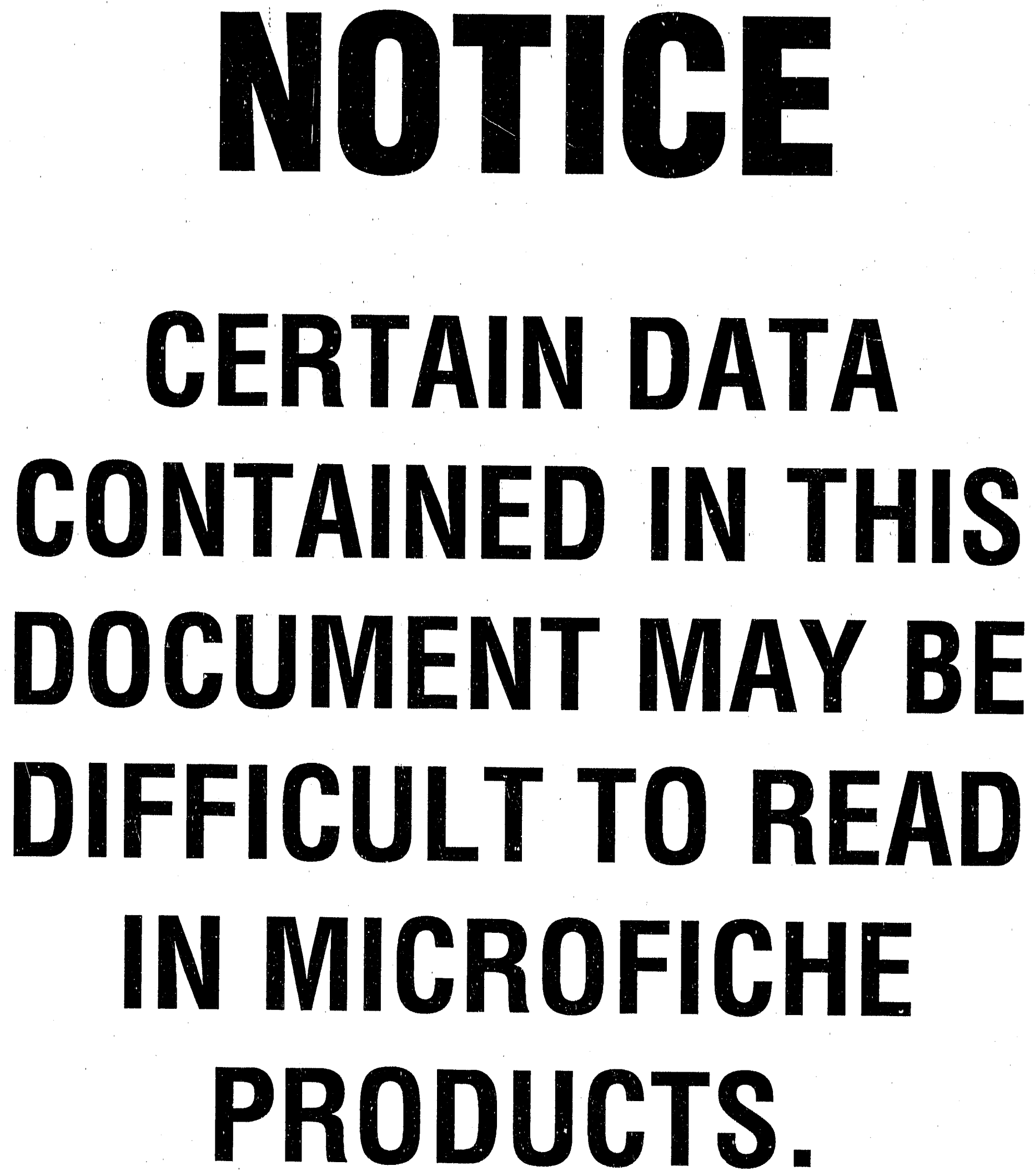


\title{
Hanford Waste Vitrification Plant Applied Technology Plan
}

\author{
O. L. Kruger
}

Date Published

September 1990

Prepared for the U.S. Department of Energy Office of Environmental Restoration and Waste Management

\footnotetext{
(2) Westinghouse P.O. Box 1970 


\section{HANFORD WASTE VITRIFICATION PLANT \\ APPLIED TECHNOLOGY PLAN}

WESTINGHOUSE HANFORD COMPANY APPROVALS:

$$
\text { EXelen }
$$

E. T. Weber, Manager

HWVP Technology

$\frac{9 / 26 / 90}{\text { Date }}$

W. C. Miller, Manager

$$
\text { W C Mille }
$$

HWVP Project Engineering

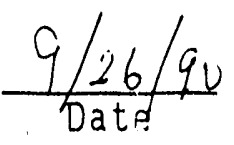

J. F. Erben, Manager

HWVP Business Management

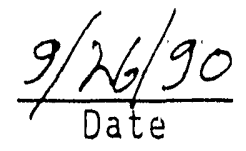

M. J. Rackley, Manager

HWVP Startup and Testing

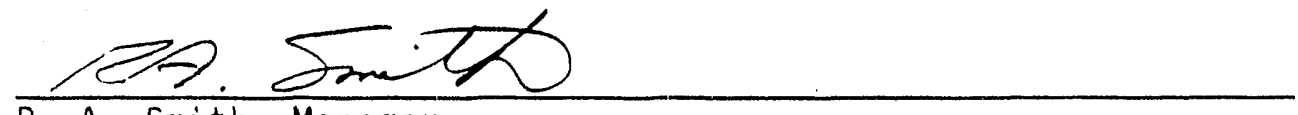

R. A. Smith, Manager

HWVP Project

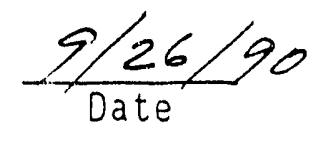

PACIFIC NORTHWEST LABQRATGRY CONCURRENCE:

C. R. Allen, Manager

HWVP Project
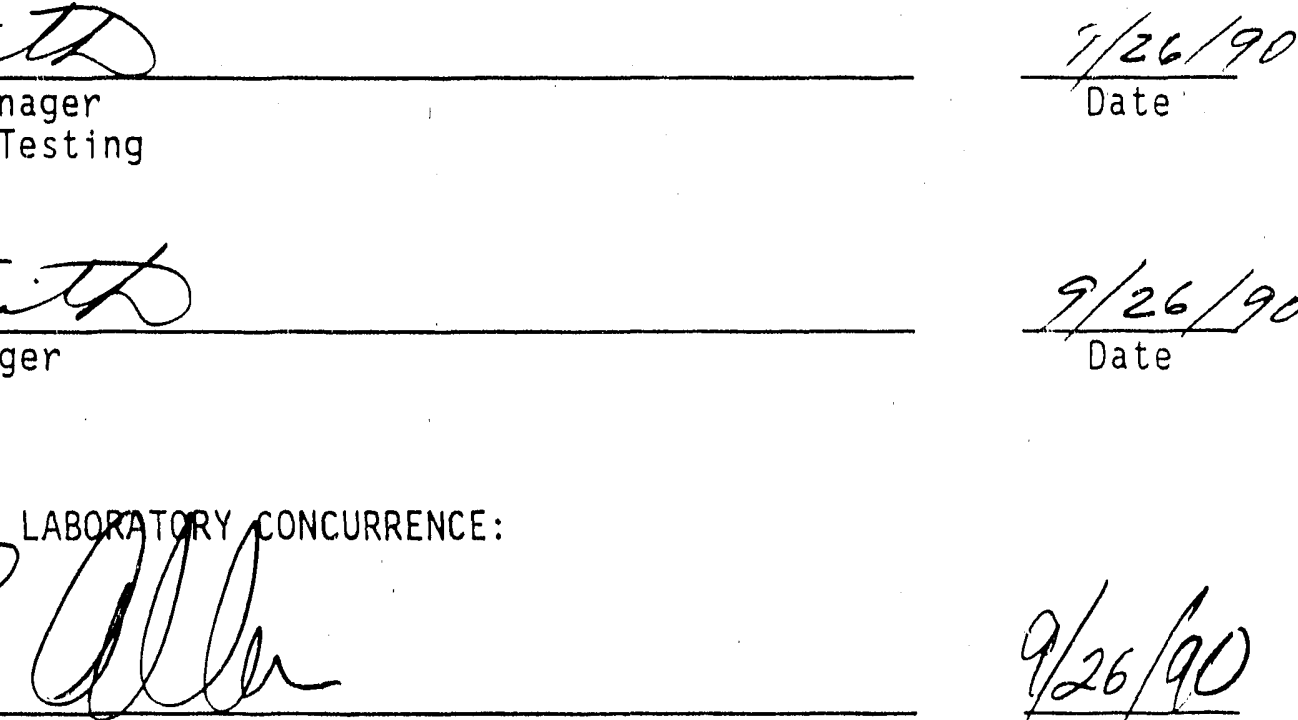

U.S. DEPARTMENT OF ENERGY-RICHLAND OPERATIONS OFFICE APPROVAL:

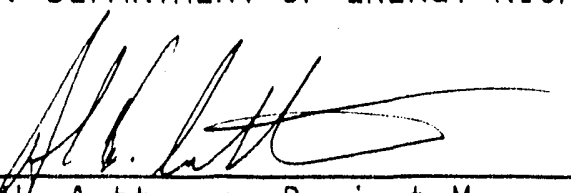

J. At. Anttonen, Project Manager

Vitrification Project Office

$$
\frac{9 / 2 z / 9 u}{\text { Date }}
$$


WHC -EP-0350

\title{
HANFORD WASTE VITRIFICATION PLANT \\ APPLIED TECHNOLOGY PLAN
}

\author{
0. L. Kruger
}

\section{ABSTRACT}

This Applied Technology Plan describes the process development, verification testing, equipment adaptation, and waste form qualification technical issues and plans for resolution to support the design, permitting, and operation of the Hanford Waste Vitrification Plant. The scope of this Plan includes work to be performed by the research and development contractor, Pacific Northwest Laboratory, * other organizations within Westinghouse Hanford Company, universities and companies with glass technology expertise, and other U.S. Department of Energy sites. All work described in this Plan is funded by the Hanford Waste Vitrification plant Project and the relationship of this Plan to other waste management documents and issues is provided for background information.

Work to be performed under this $P 7$ an is divided into major areas that establish a reference process, develop an acceptable glass composition envelope, and demonstrate feed processing and glass production for the range of Hanford Waste Vitrification Plant feeds. Included in this work is the evaluation and verification testing of equipment and technology obtained from the Defense Waste Processing Facility, the West Valley Demonstration Project, foreign countries, and the Hanford Site. Development and Energy.

*Operated by Battelle Memorial Institute for the U.S. Department of 
verification of product and process models and other data needed for waste form qualification documentation are also included in this plan.

Applied technology work has been planned in detail to support the scheduled design, permitting, and startup activities for the Hanford Waste Vitrification Plant Project. Summary level milestone schedules are provided for information and reference.

The total estimated cost (in escalated dollars) for applied technology work from fiscal year 1991 through fiscal year 1999 is $\$ 136,840,000$ expense plus $\$ 15,490,000$ capital equipment not related to construction. A cost breakdown is given by task and year of expenditure. The above figures are based on "required case" planning to support planned milestones and other activities leading to the December 999 hot startup of the Hanford Waste Vitrification Plant. 
WHC-EP-0350

\section{EXECUTIVE SUMMARY}

\section{BACKGROUND}

The need for a Hanford Site vitrification facllity, development of sitespecific vitrification technology, and, hence, this Applied Technology Plan (herein referred to as Plan), was formally defined through the Environmental Impact Statement (EIS) process, which began in the early 1980's. Disposal alternatives for Hanford defense waste (HDW) were evaluated in DOE/EIS-0113, Final Environmental Impact Statement: Disposal of Hanford Defense High-Level, Transuranic, and Tank Wastes, Hanford Site, Richland, Washington. 1 As a result of this EIS process, a disposal plan was chosen in the EIS Record of Decision. ${ }^{2}$ This reference Hanford Site plan calls for disposal of doubleshell tank (DST) stored defense high-level and transuranic wastes via immobilization in glass by the vitrification process with temporary onsite storage of glass-filled canisters until final disposal in a geologic repository.

Implementation of the disposal plan for Hanford Site defense wastes is described in DOE/RL-89-32, Hanford Site Waste Management Plan ${ }^{3}$ (HSWMP) and the Hanford Site-specific plan, DOE-RL 89-10, Environmental Restoration and Waste Management Site-Specific Plan for the Richland Operations office: Detailed Information (HSERWMP). " For DST wastes, disposal plans are further described in WHC-EP-0229, Double-Shel7 Tank Waste Disposal Integration Plan. ${ }^{5}$

A description of the technology required to meet the reference waste management plan is provided in WHC-EP-0212-1, Hanford Site Environmental Restoration and Waste Management Technology Plan (HSERWMTP).6 
WHC - EP - 0.350

One of the issues in the HSERWMTP is DST-6, Immobilization (GIass). The intent of the HSERWMTP is to include all expense funding required to complete the Hanford Waste Vitrification Plant (HWVP) Project, prepare the plant for hot startup, and submit waste form qualification (WFQ) reports for the different wastes to be processed. A preliminary HWVP Technology Plan was prepared in 1985 as a supporting document to the HSERWMTP (formally called Hanford Waste Management Technology Plan) to provide a more detailed description of the technology needed to construct and operate a vitrification facility. This Plan has been updated annually through 19897 and is limited in scope to technology that requires development or confirmation testing. Other HWVP technology- and design-related expense-funded activities are not included.

This Plan contains a description of HWV technical issues requiring resolution before hot startup. The term "issue" is used in this Plan to denote a specific area of technical concern, while it is used in the HWMTP to denote all vitrification expense-funded work collectively. The major purpose of this Plan is to document planning of technology activities to support Project design, process development, verification testing, and WFQ technical support needs. This Plan includes fiscal year (FY) 1991 to FY 1999 applied technology funding requirements for Project budgeting and establishes the basis for statement of work instructions to the performing organizations. Annual document revisions will be prepared until all HWVP technical issues are closed. These annual updates will be completed to meet the timing required for updating the HSERWMTP and the HWMP.

The HWVP approach to technology planning is based on adapting existing U.S. Department of Energy (DOE)-developed vitrification technology to 
WHC-EP-0350

accommodate unique Hanford Site waste feeds, address site-specific regulatory requirements, and evaluate potential areas of significant cost savings. Vitrification has a technology base centered in the glass and ceramics industry. Application of this technology to nuclear waste immobilization has been developed in federally sponsored programs throughout the past 15 to 20 years. Two U.S. vitrification facilities are scheduled to be operational before the HWVP construction is completed: (1) the West Valley Demonstration Project (WVDP) in West Valley, New York, and (2) the Defense Waste Processing Facility (DWPF) at the Savannah River site in Aiken, South Carolina. Technology and design technical exchanges are held frequently with DWPF and WVDP. There are also evaluations of information available from technical exchanges and meetings between the HWVP and other high-level waste vitrification projects around the world.

Waste form acceptance requirements are being defined through negotiation with the Office of Civilian Radioactive Waste Management and specifically, the Yucca Mountain Project. These requirements will ensure that the vitrified Hanford Site defense high-level wastes will meet the candidate geologic repository requirements for nuclear waste acceptarice. Although specific requirements for the vitrified Hanford Site waste are currently being defined, they are expected to be similar to those preliminary requirements defined for the waste to be vitrified at the DWPF. The technical approach to WFQ for the HWVP Project is based on the following concepts:

- Defining WFQ requirements

- Designing the process to comply with requirements 
WHC - EP -0350

- Analyzing and testing the process and product to show compliance with requirements

- Operating the facility within the verffied process limitiations.

These activities are covered under the overall technology planning for the HWVP.

\section{PLAN ORGANIZATION AND COST}

This Plan is organized according to the work breakdown structure (WBS) for the HWVP Project and the task management structure of the research and development contractor, Pacific Northwest Laboratory (operated by Battelle Memortal Institute for the DOE), that performs the major portion of the applied technology-related work. The work has been divided into the following categories:

\section{Pacific Northwest Laboratory}

- Applied technology management

- Quality assurance

- Process development and verification testing

- Equipment adaptation

- Waste form qualification

\section{Westinghouse Hanford}

- Plant equipment development

- Process testing

- Waste form qualification testing. 
An issue description, scope, status, remaining tasks, assoctated scheduling, and estimated costs are described for work to be performed from fiscal year (FY) 1991 to FY 1999. The schedules have been integrated to define relationships between issue resolution and requirements for Definitive Design, WFQ, HWVP startup, and other Project-related activities. This P1an reflects integration of the applied technology with Definitive Design and other HWVP planned activities and schedules. Technology funding constraints have required scheduling the completion of some technology work after the start of the Definitive Design phase.

Estimated cost and schedule data in this document are for planning purposes only. Cost and schedule baselines are documented elsewhere. However, the total technology costs in this Plan are consistent for the HWVP Project. Technology activities for FY 1991 and FY 1992 are also consistent with the key activity summary and priority list included in the FY 1992 budget submittal. The work addressed by this Plan for FY 1991 through FY 1999 has a total cost estimate of $\$ 136,840,000$ expense and $\$ 15,490,000$ capital equipment not related to construction (CENRTC). All cost estimates are escalated to year of expenditure. Costs for applied technology, including those from previous years, are as follows: 
$W H C-E P-0350$

\begin{tabular}{|c|c|c|}
\hline $\begin{array}{l}\text { Through } \\
\text { fiscal year } \\
\end{array}$ & Expense & CENRTC \\
\hline 1988 & $12,144,000$ & $\ldots$ \\
\hline 1989 & $3,822,000$ & $\ldots$ \\
\hline 1990 & $6,952,000$ & $\ldots$ \\
\hline 1991 & $12,475,000$ & $3,000,000$ \\
\hline 1992 & $21,010,000$ & $10,290,000$ \\
\hline 1993 & $22,140,000$ & $2,200,000$ \\
\hline 1994 & $20,565,000$ & $\cdots$ \\
\hline 1995 & $16,800,000$ & - \\
\hline 1996 & $13,960,000$ & $\cdots$ \\
\hline 1997 & $10,605,000$ & - \\
\hline 1993 & $10,520,000$ & $\cdots$ \\
\hline 1999 & $8,765,000$ & $\cdots$ \\
\hline Total & $159,758,000$ & $15,490,000$ \\
\hline
\end{tabular}

These estimated costs are required to close issues identified for process development and verffication testing, equipment adaptation, operations support, and WFQ. The applied technology work described in this Plan will provide needed input for design, WFQ, and permitting leading to hot startup.

This Plan describes the methodology that will be used to develop and characterize an acceptable glass composition envelope for processing the various Hanford Site wastes. Current activities also involve the lise of a full-scale feed preparation system for melter-integrated testing to verify equipment performance, evaluate operating parameters, and provide data for WFQ. Vitrification testing involves performance assessment of the HWVP 
melter design for processing Hanford Site wastes that contain high concentrations of sludge-forming components, including ztrconium and noble metals. Processing of radioactive wastes into glass for WFQ testing is also included in this Plan. Specific issues related to Hanford Stte wastes and the HWVP design are addressed.

DOE/EIS-0113, Final Environmental Impact Statement: Disposal of Hanford Defense High-Level, Transuranic, and Tank Wastes, Hanford Site, Richland, Washington, U.S. Department of Energy, Washington, D.C., 1987.

2Disposal of Hanford Defense High-Level, Transuranic, and Tank Wastes, Hanford Site, Richland, Washington; Record of Decision, U.S. Department of Energy, Washington, D.C., 1988.

3 DOE/RL-89-32, Hanford Site Waste Management Plan, U.S. Department of Energy, Richland, Washington, 1989.

4 DOE-RL 89-10, Environmental Restoration and Waste Management SiteSpecific Plan for the Richland Operations Office: Detailed Information, U.S. Department of Energy-Richland Operations Office, Richland, Washington, 1989.

${ }^{5}$ WHC-EP-0229, Revision 1, Double-Shell Tank Waste Disposal Integration Plan, C. A. Augustine, Westinghouse Hanford Company, Richland, Washington, 1990.

6WHC-EP-0212-1, Hanford Site Environmental Restoration and Waste Management Technology Plan, R. P. Anantatmula, Westinghouse Hanford Company, Richland, Washington, 1990.

7 WHC-EP-0224, Hanford Waste Vitrification Plant Applied Technology Plan, 0. L. Kruger, Westinghouse Hanford Company, Richland, Washington, 1989. 


\section{CONTENTS}

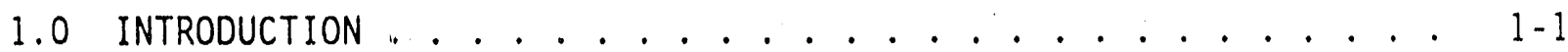

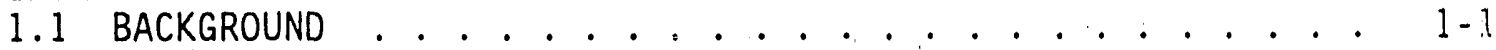

1.2 OBJECTIVE . . . . . . . . . . . . . . . . 1 . . .

1.3 APPLIED TECHNOLOGY PLAN SCOPE ............ 1-. 1 . .

1.4 APPLIED TECHNOLOGY PLAN APPROACH ......... $1-2$

1.5 IECHNOLOGY INTEGRATION WITH HANFORD WASTE VITRIFICATION
PLANT DETAILED DESIGN. . 1.4

1.6 TECHNOLOGY INTEGRATION WITH OTHER HANFORD SITE WASTE

MANAGEMENT ACTIVITIES ................ 1-13

1.7 APPLIED TECHNOLOGY PLAN ORGANIZATION ....... $1-16$

1.8 SUM?IARY OF MAJOR CHANGES IN THE FISCAL YEAR 1990 APPLIED

TECHNDLOGY PLAN ................. $1-19$

1.9 AUTHORSHIP . . . . . . . . . . . . . . . . 1-20

2.0 APPLIED TECHNOLOGY MANAGEMENT - PACIFIC NORTHWEST LABORATORY . . . 2-1

3.0 QUALITY ASSURANCE - PACIFIC NORTHWEST LABORATORY . . . . . . 3-1

4.0 PROCESS DEVELOPMENT AND VERIFICATION TESTING - PACIFIC NORTHWEST LABORATORY . . . . . . . . . . . 4-1

4.1 WASTE FORM DEVELOPMENT . . . . . . . . . . . 4-2

4.1.1 Glass Composition Envelope Definition . . . 4 4-2

4.2 FEED PROCESSING . . . . . . . . . 4-4

4.2.1 Redox/Rheology Control ............ 4-6

4.2.2 Slurry-Integrated Performance Testing . . . . . . 4-10

4.3 VITRIFICATION .................... 4- . . . . . . .

4.3.1 Statement of Issue . . . . . . . . . . 4-17

4.3.2 Scope ............... . 4-17

4.3.3 Status . . . . . . . . . . . . 4-18

4.3.4 Remaining Tasks .............. . 4-19

4.3.5 Schedule Requirements . . . . . . . . . . 4-22

4.3 .6 Costs ............. . . 4-22

4.4 MELTER OFFGAS SYSTEM . . . . . . . . . . . . . . 4-22

4.4.1 Melter Offgas System Performance Evaluation . . . . 4-22

4.5 WASTE TREATMENT . . . . . . . . . . . . . . . . 4-27

4.5.1 Statement of Issue . . . . . . . . . . . 4-27

4.5 .2 Scope ............... . . 4-28

4.5.3 Status .............. . . 4-28

4.5.4 Remaining Tasks ............... 4- 4-30

4.5.5 Schedule Requirements . . . . . . . . . . 4-30

4.5.6 Costs . . . . . . . . . . . . 4-30

4.6 HANFORD WASTE VITRIFICATION PLANT APPLIED TECHNOLOGY

4.6.1 Statement of Issue ............. 4-31

4.6.2 Scope ................. 4-32

4.6.3 Status ............... . 4-32

4.6.4 Remaining Tasks .............. . 4-32

4.6.5 Schedule Requirements . . . . . . . . . . 4-32

4.6 .6 Costs ............. 4-32 
CONTENTS (cont)

5.0 EQUIPMENT ADAPTATION - PACIFIC NORTHWEST LABORATORY . . . . . 5-1

5.1 MELTER/TURNTABLE SYSTEM . ............... 5-1

5.1.1 Melter Performance Assessment . . . . . . . . . . . 5-1

5.1.2 Plant Prototypic Glass Melter ... . . . . . . . 5-4

5.1.3 Melter Decommissioning . . . . . . . . . . . . . . 5-8

5.2 CANISTER CLOSURE, LEAK TIGHTNESS VERIFICATION, AND

DECONTAMINATION .................. . . 5-9

5.2.1 Canister Ciosure and Weld Verification... . . 5-10

5.2.2 Canister Leak Check ............ . 5-12

5.2.3 Canister Decontamination ... . . . . . . . . . 5-14

5.2.4 Canister Rework/Qualification. . . . . . . . . 5-16

5.2.5 Glass Removal from Canister ........... 5-18

5.3 MATERIALS EVALUATION ............... . 5-20

5.3.1 Statement of Issue ............. 5-20

5.3.2 Scope ................ 5-. . . . 21

5.3.3 Status.................. . . 5-21

5.3.4 Remaining Tasks ............... 5-22

5.3.5 Schedule Requirements .......... . . 5-22

5.3.6 Costs ................. 5-23

5.4 OFFGAS LINE PLUGGING ............... . 5-23

5.4.1 Statement of Issue ............. 5-23

5.4.2 Scope .................. . . 5-23

5.4 .3 Status.................. $5-23$

5.4.4 Remaining Tasks ........ . . . . . . . 5-24

5.4.5 Schedule Requirements ........... $5-24$

5.4 .6 Costs ................. . 5-25

5.5 ANALYTICAL METHODS ................ . 5-25

5.5.1 Statement of Issue.............. 5-25

5.5.2 Scope ................... 5-25

5.5 .3 Status................... $5-26$

5.5.4 Remaining Tasks ............... . 5-26

5.5.5 Schedule Requirements .......... . . 5-26

5.5 .6 Costs .................. . 5-27

6.0 WASTE FORM QUALIFICATION - PACIFIC NORTHWEST LABORATORY . . . . $6-1$

6.1 PRODUCTION CON IROL AND PRODUCT QUALIFICATION . . . . . . . 6-2

6.1.1 Product Models ............... . $6-4$

6.1.2 Process Models .................. . 6-6

6.2 PRODUCT AND PROCESS TESTING . . . . . . . . . . . . . . . . . $6-9$

6.2.1 Glass Properties and Phase Behavior . . . . . 6-9

6.2.2 Canistered Product Qualification........ 6-12

6.2.3 Canister Drop Testing . . . . . . . . . . . . . 6-14

6.2.4 Radioactive Process/Product Laboratory Tests . . . . 6-16

6.2.5 Radioactive Bench-Scale Tests . . . . . . . . 6-18 


\section{CONTENTS (cont)}

7.0 PLANT EQUIPMENT DEVELOPMENT - WESTINGHOUSE HANFORD . . . . . . . 7-1

7.1 ANALYTICAL LABORATORY SAMPLE TRACKING SYSTEM . . . . . . . 7-1

7.1.1 Statement of Issue . . . . . . . . . . . . . 7-1

7.1 .2 Scope ................. $7-1$

7.1.3 Status.................. . 7-2

7.1.4 Remaining Tasks ............ . 7-2

7.1.5 Schedule Requirements .. . . . . . . . . 7-2

7.1 .6 Costs .................. $7-2$

8.0 PROCESS TESTING - WESTINGHOUSE HANFORD . . . . . . . . . . 8-1

8.1 RADIOACTIVE WASTE SHIPMENT SUPPORT . . . . . . . . . . . . 8-1

8.1.1 Statement of Issue . . . . . . . . . . . . 8-1

8.1.2 Scope .................... $8-1$

8.1.3 Status................ 8-2

8.1.4 Remaining Tasks ............... 8-2

8.1.5 Schedule Requirements ............. 8-2

8.1.6 Costs . . . . . . . . . . . . . . . 8-2

8.2 FRIT VENDOR QUALIFICATION . . . . . . . . . . 8-2

8.2.1 Statement of Issue . . . . . . . . . . . 8-2

8.2.2 Scope .................... $8-4$

8.2.3 Status................. $8-4$

8.2.4 Remaining Tasks . . . . . . . . . . . 8-4

8.2.5 Schedule Requirements . . . . . . . . . . . 8-4

8.2.6 Costs . . . . . . . . . . . . . . . 8-4

8.3 PROCESS TESTING IN THE INTEGRATED DEFENSE WASTE PROCESSING
FACILITY MELTER SYSTEM ..................... $8-5$

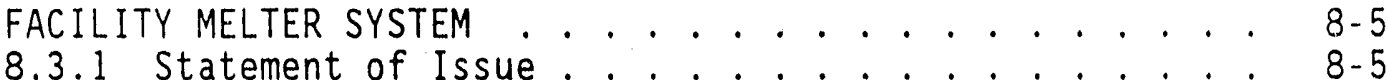

8.3.2 Scope .............. 8-6

8.3.3 Status.................. 8-6

8.3.4 Remaining Task . . . . . . . . . . . . . . 8-6

8.3.5 Schedule Requirements . . . . . . . . . . 8-6

8.3.6 Costs................. . . . $8-6$

9.0 WASTE FORM QUALIFICATION TESTING - WESTINGHOUSE HANFORD . . . $9-1$

9.1 ANALYTICAL STANDARDS AND METHODS ADAPTATION . . . . . . . . $9-1$

9.1.1 Statement of Issue............... . . 9-1

9.1.2 Scope ..................... . 9-1

9.1.3 Status . . . . . . . . . . . . . . . . . . 9-1

9.1.4 Remaining Tasks . . . . . . . . . . . . . 9-1

9.1.5 Schedule Requirements ............. . 9-2

9.1 .6 Costs ................. $9-2$

10.0 COST ESTIMATE SUMMARY ........................ $10-1$

11.0 SCHEDULE............................ . . . $11-1$

12.0 REFERENCES........................ 12-1

13.0 GLOSSARY ....................... $13-1$ 
WHC -EP- 0350

\section{LIST OF FIGURES}

1-1 Hanford Waste Vitrification Plant Schedule Comparison with Defense Waste Processing Facility and West Valley Demonstration Project Major Construction and Operation Phases...................... 1-3

1-2 Hanford Waste Vitrification Plant Applied Technology Log ic Diagram . . . . . . . . . . . . . . . . 1-5

1-3 Relationship of Hanford Waste Vitrification Plant Applied Technology Plan to Waste Management Documents . . . . . . . 1-14

11-1 Hanford Waste Vitrification Plant Technology Summary Schedule....................... 11-2 
WHC-EP- 0350

\section{LIST OF TABLES}

1-1 Applied Technology Plan Issues Related to Hanford Waste Vitrification Plant Detailed Design .......... 1-6

1-2 Changes to List of Fiscal Year 1989 Technology Plan Issues.. . 1-21

4-1 Glass Composition Envelope Definition Milestone List. . . . . 4-5

4-2 Redox/Rheology Control Milestone List . . . . . . . . . . 4-9

4-3 Slurry-Integrated Performance Testing Milestone List. . . . . . 4-15

4-4 Vitrification Milestone List... . . . . . . . . . . . 4-23

4-5 Melter Offgas System Performance Evaluation Milestone List . . 4-26

4-6 Waste Treatment Milestone List. . . . . . . . . . . . . . 4-31

4-7 Hanford Waste Vitrification Plant Applied Technology Handbook 4-33

5-1 Melter Performance Assessment Milestone List . . . . . . . . . 5-5

5-2 Plant Prototypic Glass Melter Milestone List . . . . . . . 5-7

5-3 Melter Decommissioning Milestone List . . . . . . . . 5-9

5-4 Canister Closure and Weld Verification Milestone List . . . . 5-12

5-5 Canister Leak Check Milestone List . . . . . . . . . . . . 5-14

5-6 Canister Decontamination Milestone List. . . . . . . . . . 5-17

5-7 Canister Rework Milestone List.............. . 5-18

5-8 Glass Removal from Canister Milestone List. . . . . . . . . . 5-20

5-9 Materials Evaluation Milestone List . . . . . . . . . . 5-22

5-10 Offgas Line Plugging Milestone List . . . . . . . . . . 5-24

5-11 Analytical Methods Milestone List . . . . . . . . . . . 5-27

6.1 Product Models Milestone List . . . . . . . . . . . . . . 6-7

6-2 Process Models Milestone List . . . . . . . . . . . . . . 6-10

6-3 Glass Properties and Phase Behavior Milestone List...... . 6-12

6-4 Canistered Product Qualification Milestone List . . . . . . . 6-14

6-5 Canister Drop Testing Milestone List . . . . . . . . . . . . . 6-16 
WHC-EP- 0350

\section{LIST OF TABLES (cont)}

6-6 Radioactive Process/Product Laboratory Tests Milestone List . , 6-18

6-7 Radioactive Bench-Scale Tests Milestone List . . . . . . . 6-21

7-1 Analytical Laboratory Sample Tracking System Milestone List . 7-3

8-1 Radioactive Waste Shipment Support Milestone List . . . . . 8-3

8-2 Frit Vendor Qualification Milestone List . . . . . . . . 8-5

8-3 Process Testing in the Integrated Defense Waste Processing

Facility Melter System Milestone List . . . . . . . . . 8-7

9-1 Analytical Standards Milestone List . . . . . . . . . 9-3

10-1 Cost Estimate Summary ............... 10-2 


\section{HANFORD WASTE VITRIFICATION PLANT APPLIED TECHNOLOGY PLAN}

\subsection{INTRODUCTION}

\subsection{BACKGROUND}

The Hanford Waste Vitrification Plant (HWVP) will convert pretreated Hanford site defense high-level waste (HLW) and transuranic (TRU) waste in underground storage tanks into a solid, vitrified (glass) form suitable for final disposal in a geologic repository.

Vitrification technology based on liquid-fed ceramic melters (LFCM) has been under development since 1974 at the Pacific Northwest Laboratory (PNL), operated for the U.S. Department of Energy (DOE) by Battelle Memorial Institute. This technology is being further developed and applied (1) at the Defense Waste Processing Facility (DWPF), which is in the final stage of construction turnover to plant operations at the Savannah River Site (SRS), Aiken, South Carolina; and (2) at the West Valley Demonstration Project (WVDP) under construction at West Valley, New York. Programs to vitrify HLW also have been established in a number of foreign countries.

The HWVP Project is applying existing vitrification technology to Hanford site waste feeds. The wastes to be processed in HWVP are pretreated neutralized current acid waste (NCAW), pretreated neutralized cladding removal waste (NCRW), and pretreated complexant concentrate (CC) and Plutonium Finishing Plant (PFP) wastes. These wastes may contain high concentrations of chromium, zirconium, and noble metals that are known to require special precautions to avoid sludge formation in glass melters. Also, the plan to pretreat all waste types other than NCAW (1.e., CC, NCRW, and PFP) by the transuranic extraction (TRUEX) process is unique for HWVP feeds. The unusual characteristics of these waste streams and HWVP requirements for waste treat. ment will lead to some modifications of designs used at other vitrification facilities.

Requirements for waste form qualification (WFQ) are being defined. Evaluation shows that equipment testing and verification, and the establishment of data and experience bases, will be needed to support WFQrelated design and reporting requirements and ol rations.

\subsection{OBJECTIVE}

The objectives of this Applied Technology Plan (herein referrud to as Plan) are as follows.

- Define the open technical issues that require resolution to support. HWVP design, operation, permitting, and WFQ activities.

- Identify the planned method of resolving issues, including testing, engineering studies, and mathellatics modeling. 
WHC - EP- 0350

- Provide the schedule and estimated costs required for resolution of the technical issues.

\subsection{APPLIED TECHNOLOGY PLAN SCOPE}

This P1an addresses only those Project technology work breakdown structure (WBS) elements involving process development and verffication testiny, equipment adaptation, and WFQ development with the majority of the work to be done by the PNL in its role as the HWVP Project research and development contractor. Excluded from the Plan are management of technology efforts by Westinghouse Hanford Company (Westinghouse Hanford) and designrelated engineering studies conducted by either the onsite or offsite architect engineer. Also, the costs and work associated with the system Evaluation and Test Factlity (SETF) are not addressed in this Plan. The need and scope of the SETF is under evaluation; however, the concept originally included full-scale feed preparation, melter and offgas system, and waste treatment equipment.

A number of studies, tests, and activities conducted as part of the overall technology effort will provide data for waste form and canister qualification. The PNL and Westinghouse Hanford specific applied technology activities needed to support WFQ are described in this PIan. The Hanford Waste Vitrification Plant Waste Form Qualification Plan - FY 1988 Update (WHC-EP-0045) (Nelson 1988) describes the total scope of planned WFQ activities. An update of this document is planned for fiscal year (FY) 1991.

\subsection{APPLIED TECHNOLOGY PLAN APPROACH}

As implied in Section 1.1, the HWVP relies heavily on existing vitriftcation technology and design experience avallable from other U.S. DOE vitrification projects, principaliy DWPF and WVDP. The major design and construction phases for all three projects presented in Figure 1-1 indicate that technology development, design, construction, startup, WFQ, and operations experience will be available to HWVP in a timely manner.

The HWVP Project is performing the following functions to maximize the use of existing technology for vitrifying Hanford Site defense HLWs and TRU wastes:

- Review existing technology bases, including design, testing, and operating experience, of DWPF, WVDP, PNL, and foreign countries

- Identify appropriate technology and experience for transfer to HWVP

- Participate in ongoing technology exchanges with DWPF and WVDP to optimize HWVP basic technology development, equipment and process adaptations, and pllot-scale testing

- Collaborate with the Federal Republic of Germany Kernsforschungszentrum Karlsruhe (KfK) staff on melter performarice and noble metals behavior. 
Figure 1-1. Hanford Waste Vitrification Plant Schedule Compartson with Defense Waste Processing Facillty and West Valley Demonstration Project Major Construction and Operation Phases.

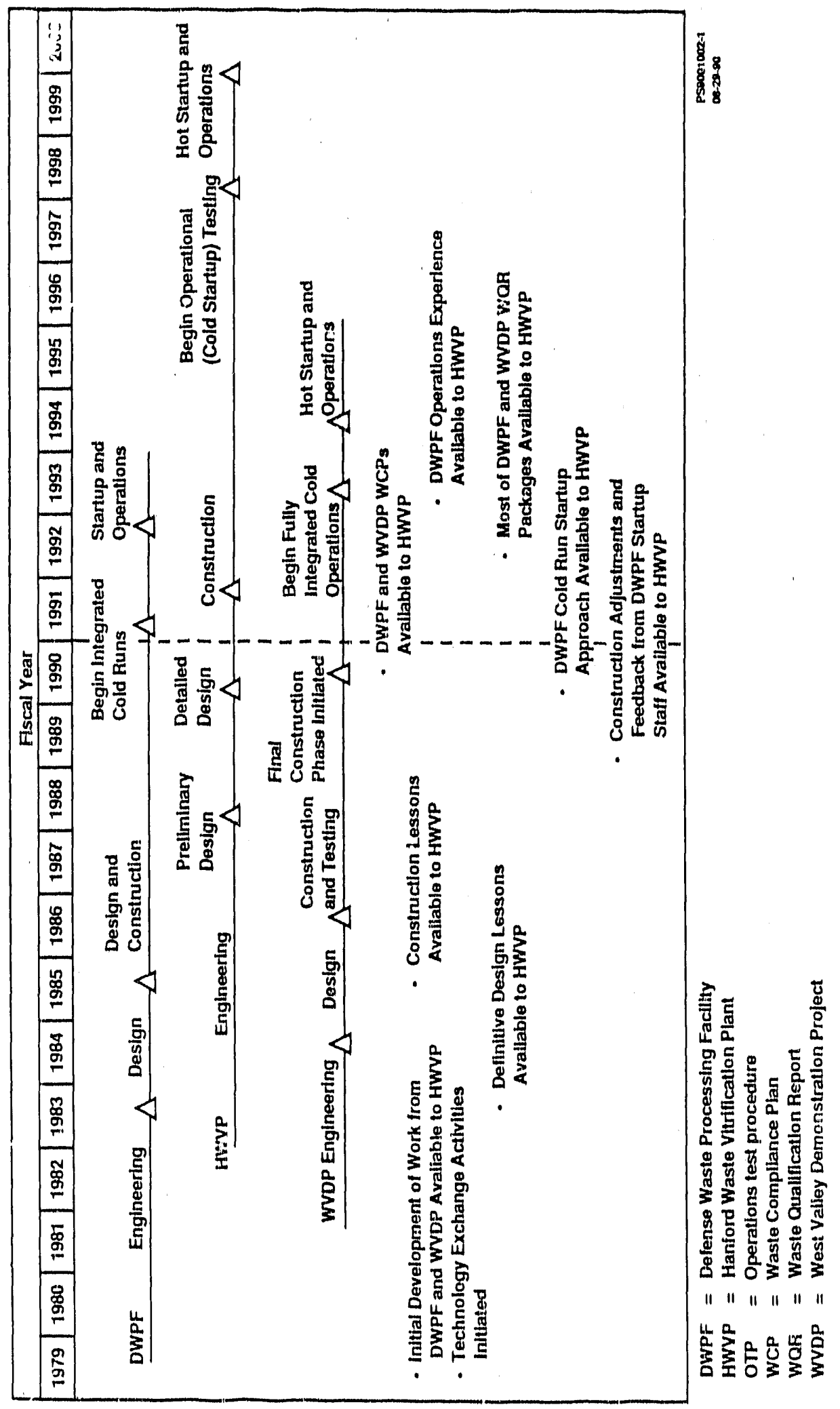


The definition of teclinology issues and planning for resolution of issues, including development and vertfication testing, has b en an tterattve process involving input from many different sources. Information exchanges with DWPF and WVDP are planned at the beginning of each fiscal year and meetings to transfer plant design and technology are held approximately once per month. Foreign information exchanges occur at different waste producer' sites several times each year and Westinghouse Hanfort. PNL, and U.S. Department of Energy-Richland Operations Office (DOE-RL) staff partictpate as appropriate. There is also participation in national and international techntcal conferences by various HWVP representatives. Any one of these sources could lead to identification of a technical issue that may require resolution. Another source of input comes from the enginaers responsible for the HWVP design at the architect engineering firm, Fluor Daniel, Inc. (Fluor). In addition, reviews of the HWVP design are held periodically to ensure compliance with safety analysis, operations, and other engineering criteria. As design activities progress, new issues may surface that must be resolved on a timely basts for design to proceed.

Documents describing the compliance strategy for WFQ and specific descriptions of the methods that will be used to meet Waste Acceptance Preliminary Specifications (WAPS) requirements are being submitted to Technical Review Groups (TRG) for formal comment by DWPF and WVDP. Comment resolution occurs through scheduled TRG meetings that include representation from HWVP. Issues related to HWVP design or technology verffication strategy may be identified or resolved through this process as the other waste producer sites provide detalls of plant operation for WFQ compliance.

The HWVP design is based on existing technology and/or technology being developed at DWPF and WVDP. However, the technology and HWVP equipment design must be adapted to process the unique Hanford Stte waste compositions in accordance with the waste treatment requirements at this site. Figure 1-2 presents the logic that is applied in review of each issue to determine if there is a noed for further analys is and/or verification testing or development and/or performance testing. Data obtained from issue resolution are incorporated into the design, regulatory permitting, plant startup, and WFQ activities via technical baseline document revistons.

\subsection{TECHNOLOGY INTEGRATION WITH HANFORD WASTE VITRIFICATION PLANT DETAILED DESIGN}

During FY 1990, the HWVP Technology organization initiated a review of applied technology activities with Fluor to identify specific issues that are important to completion of Detalled Design. As a result of this review, a 1 ist of Detailed Design requirements that need further resolution was generated and is presented in Table 1-1. The first half of this table gives a brief description of each design requirement and places it into one of the following three categories: (1) required for design, (2) to confirm design, or (3) like to have. A need date consistent with the design schedule is a) so provided. The other half of Table 1-I shows the Technology Plan issue with task number, scheduled completion date, and pertinent remarks. Some of the Detailed Design requirements have been identifled as hold points or assessment points. A hold point requires that the specific data be available 
Figure 1-2. Hanford Waste Vitrification Plant Applited Technology Logic Diagram.

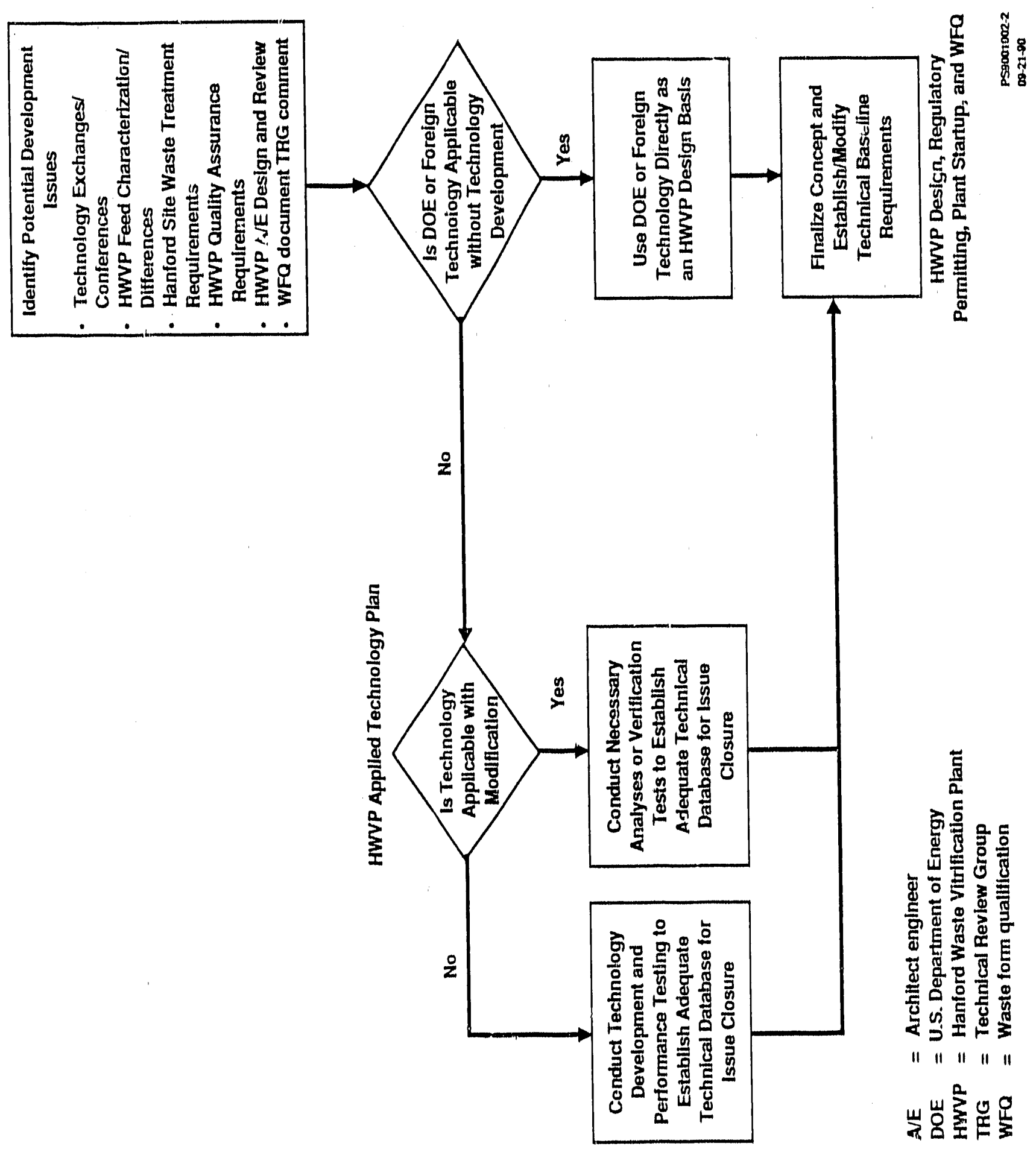


$W H C-E P-0350$

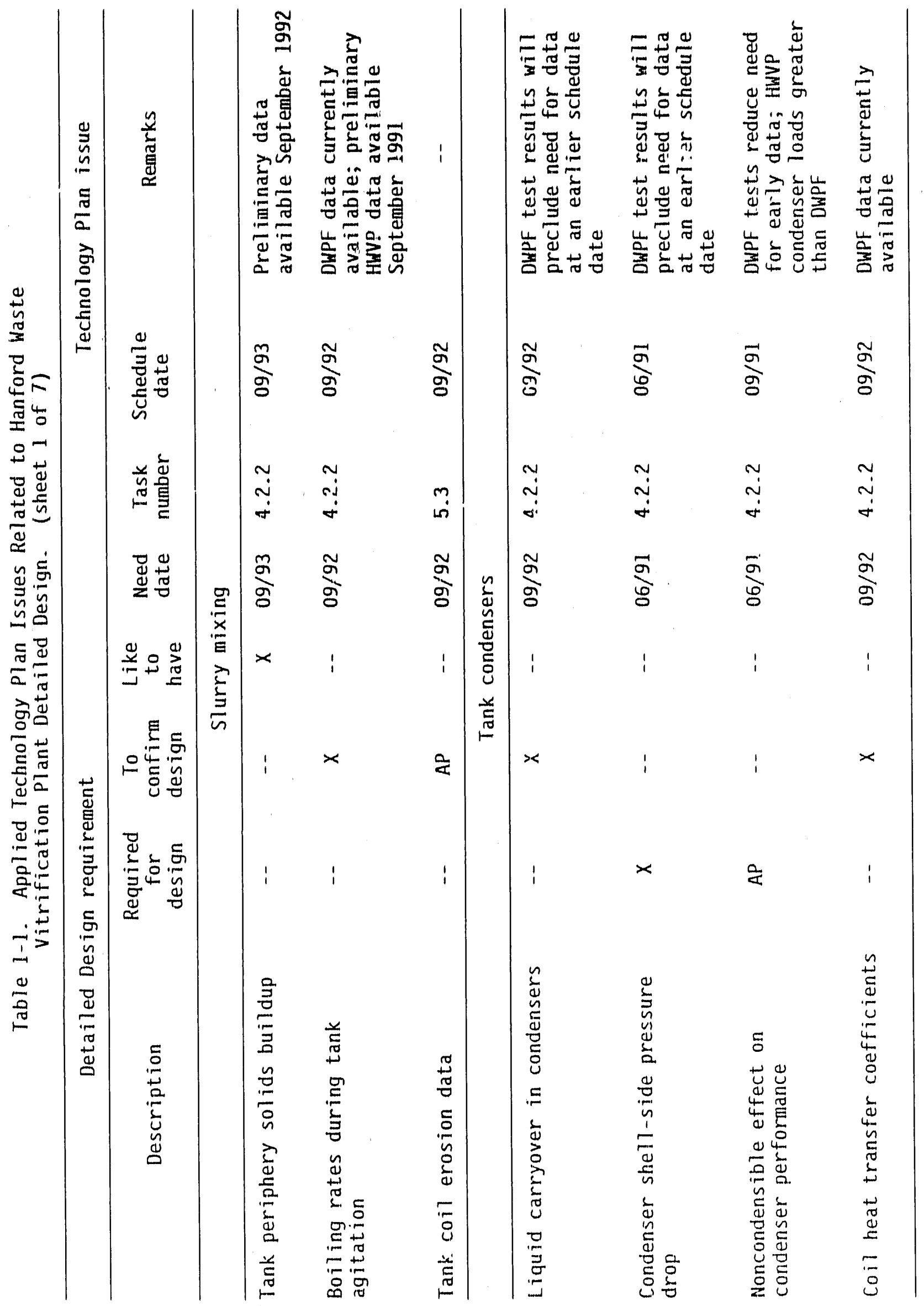


WHC-EP-0350

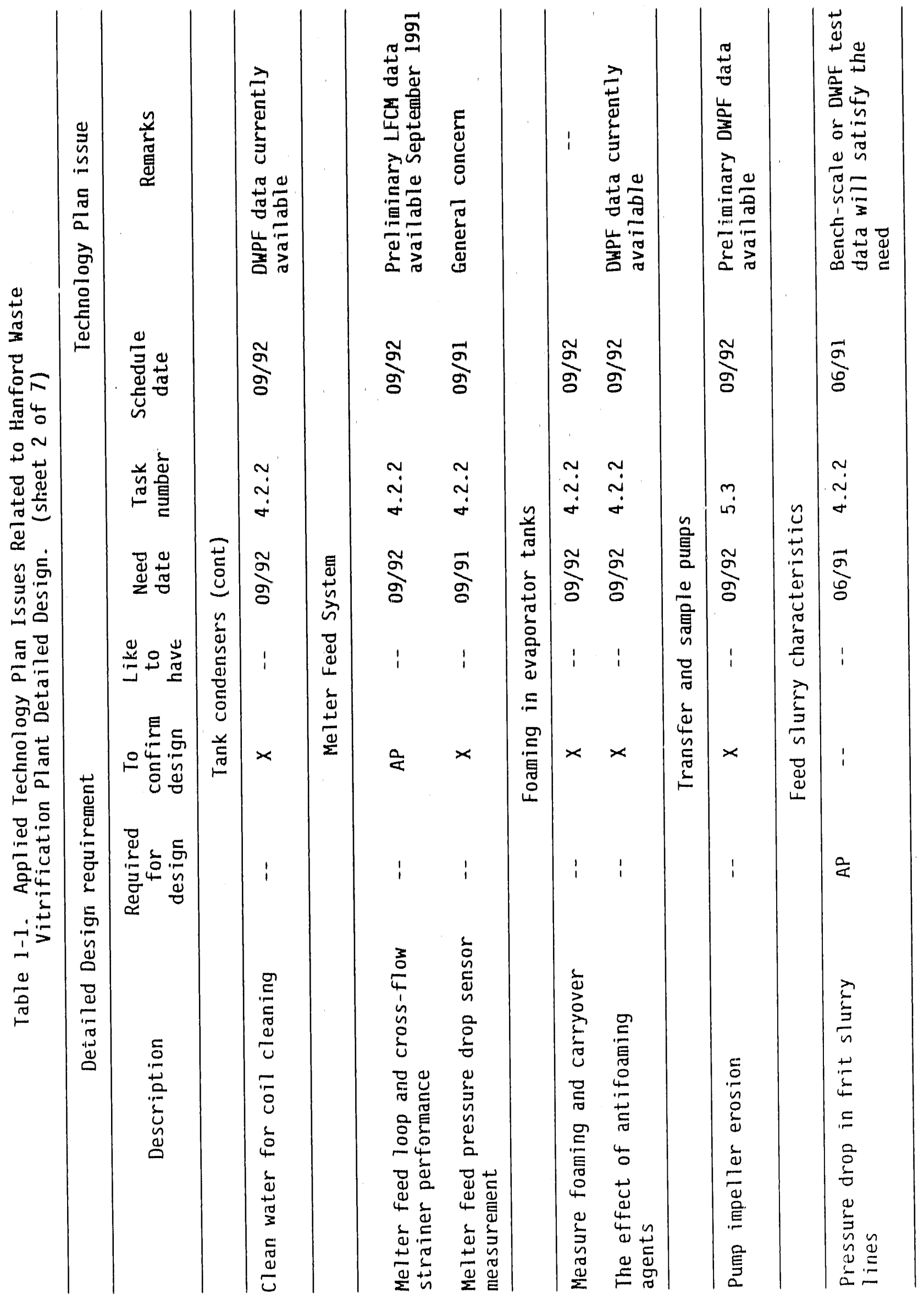


WHC - EP- 0350

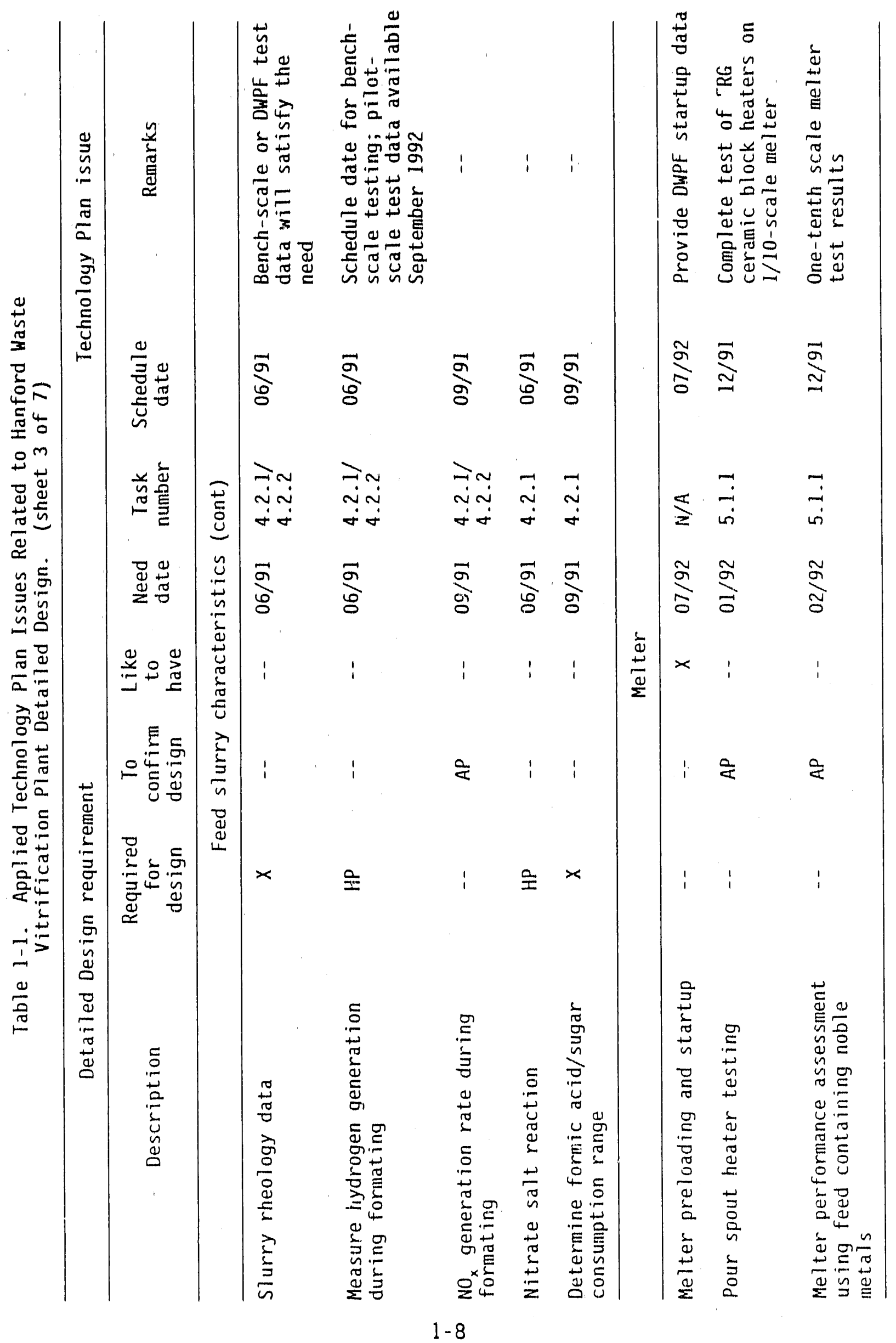


WHC-EP-0350

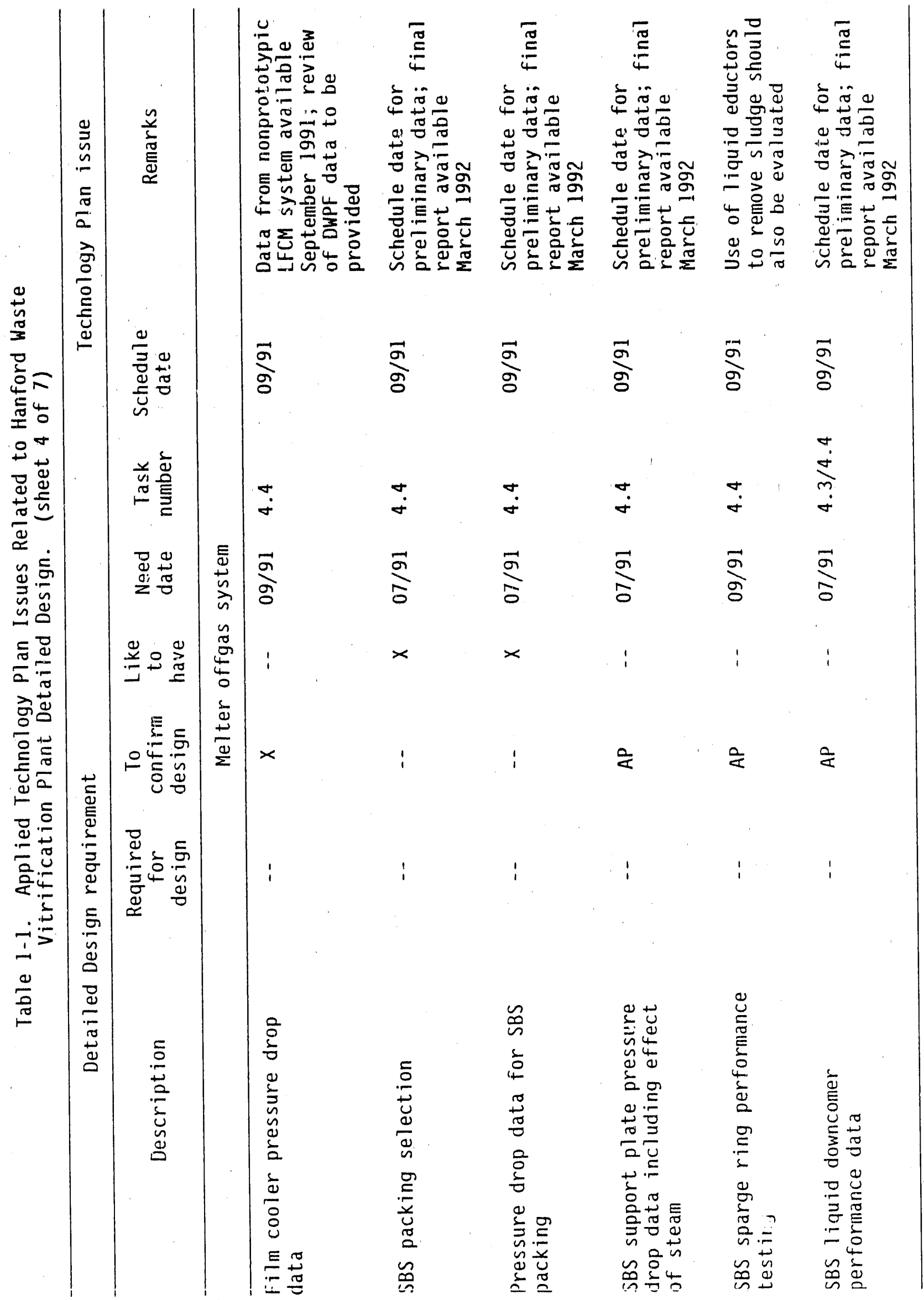


WHC-EP-0350

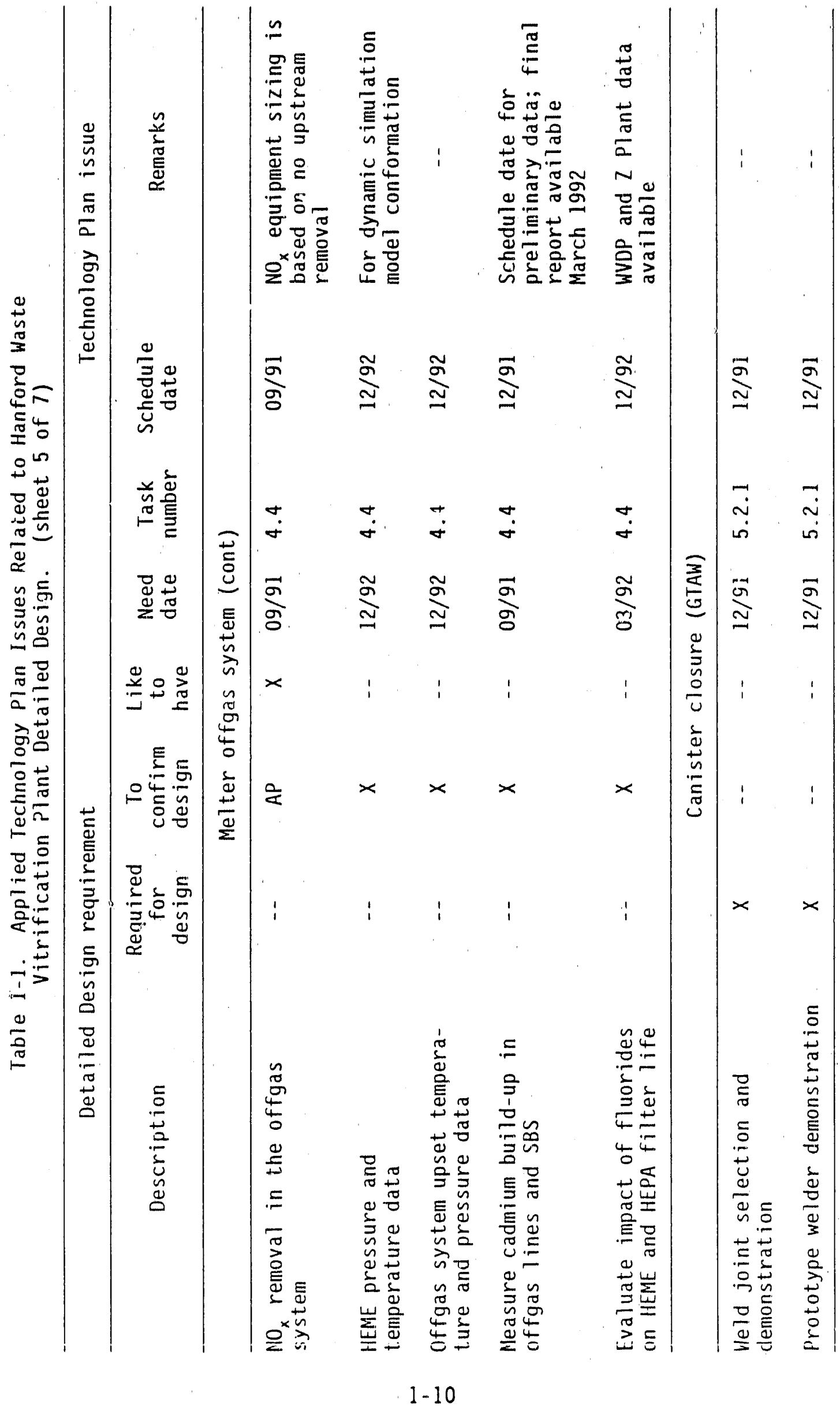


$W H C-E P-0350$

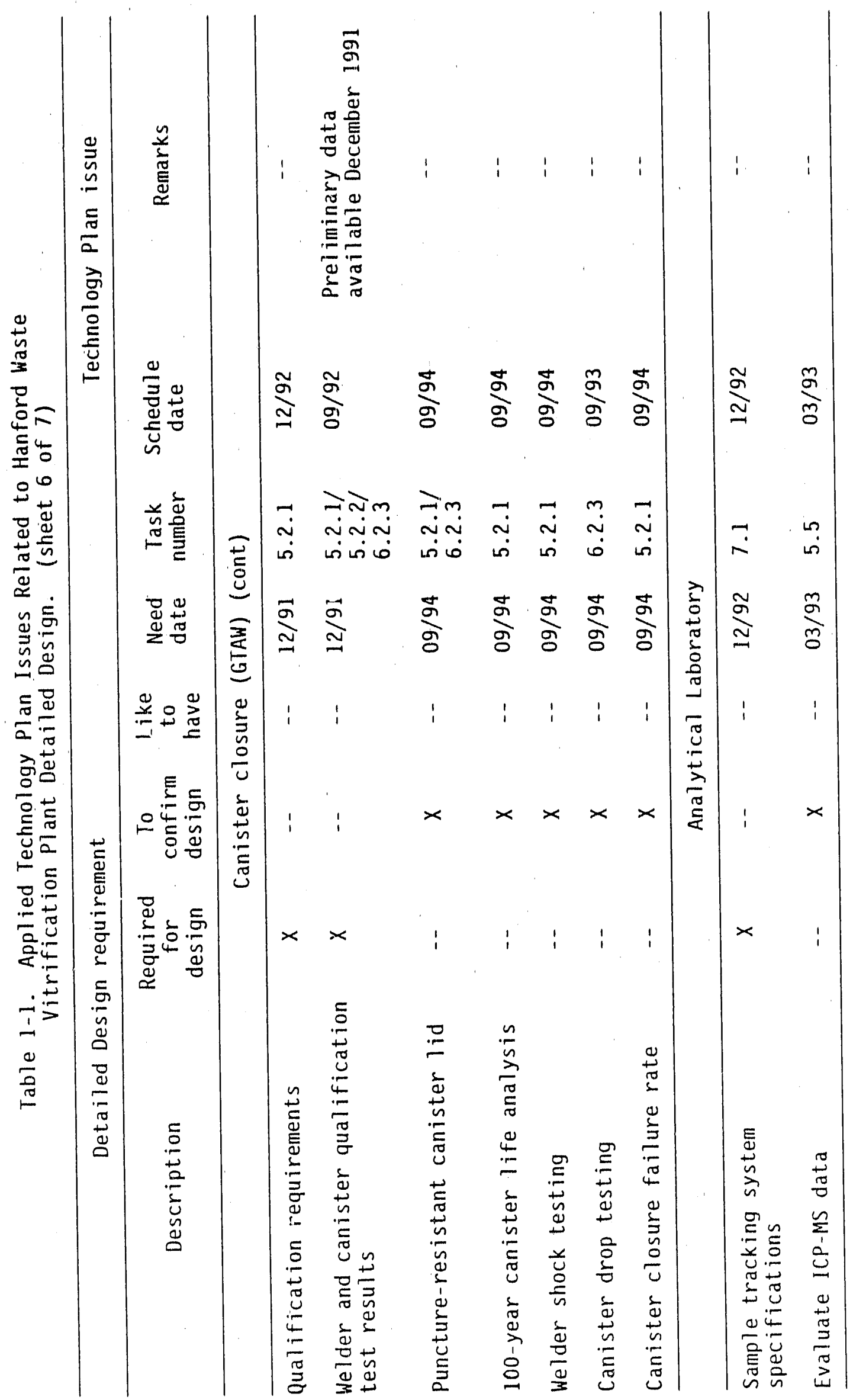




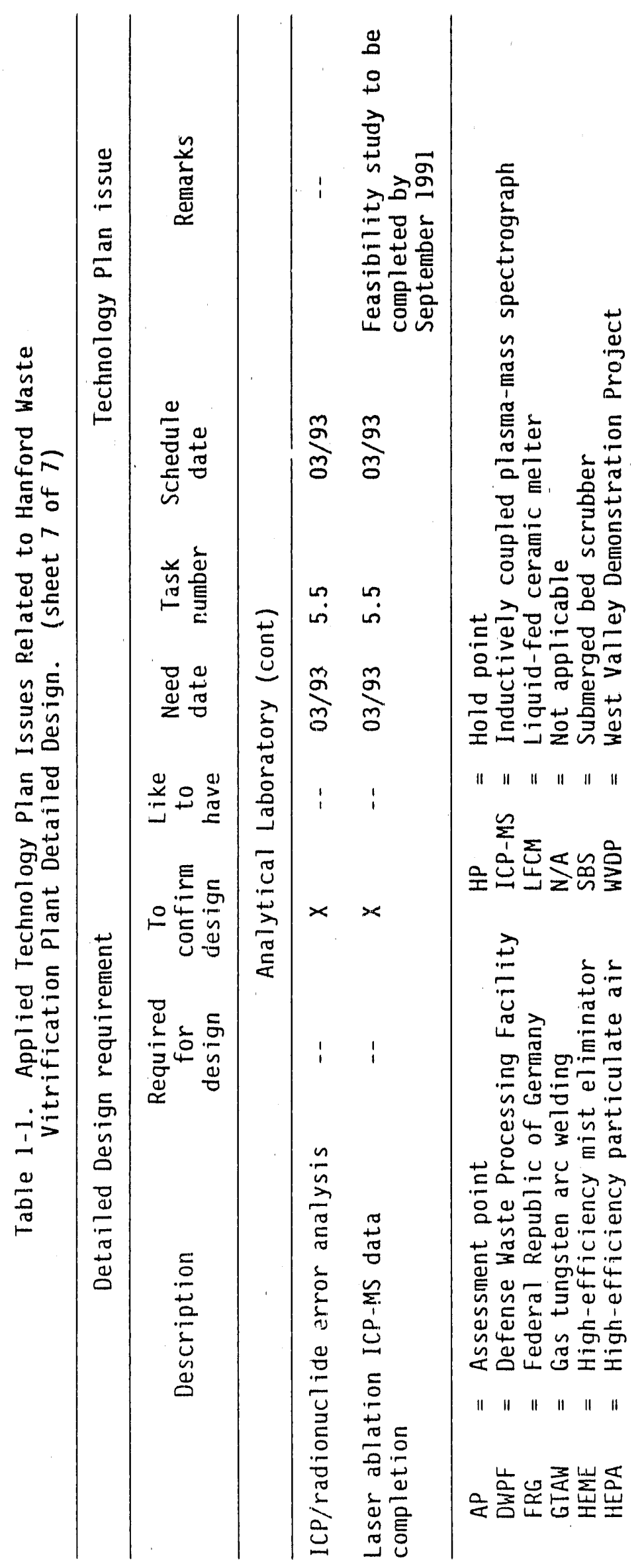


WHC - EP- 0350

before design proceeds, whereas an assessment point may raqutre a meeting of knowledgeable organization representatives to determine if sufficient technical basts information is avaflable to continue desigll. In this case, the risk of proceeding with design may be reduced sufficlently by avallability of information from preliminary work or other sources and a group assessment would be made as to a course of action to be followed.

As can be seen by compartson of the need and schedule dates in Table 1-1, Applied Technology planning is, in most cases, consistent with Detalled Design requirements. Additional assessment points could be necessary as time progresses if the Applied Technology work is delayed due to budget restrictions or inadvertent difficulties. It is important to emphasize that testing will continue beyond the HWVP Detalled Design phase to provide data for WFQ, permitting, HWVP startup operating parameters and cold run testing, and operational readiness review.

\subsection{TECHNOLOGY INTEGRATION WITH OTHER HANFORD SITE WASTE MANAGEMENT ACTIVITIES}

The need for a Hanford Site vitrification facllity, development of sitespecific vitrirication technology, and, hence, this Plan, was formally defined through the Environmental Impact Statement (EIS) process, which began in the early 1980's. Disposal alternatives for Hanford defense waste (HDW) were evaluated in DOE/EIS-0113, Final Environmental Impact Statement: Disposal of Hanford Defense High-Leve7, Transuranic, and Tank Wastes, Hanford Site, Richland, Washington (DOE 1987). As a result of this EIS process, a disposal plan was chosen as given in the EIS Record of Decision (DOE 1988). This reference Hanford site plan calls for disposal of double-shell tank (DST) stored defense high-level and TRU wastes via immobilization in glass by the vitrification process with temporary onsite storage of glass-filled cantsters until final disposal in a geologic repository.

Implementation of this disposal plan for all Hanford Site defense wastes is described in DOE/RL-89-32, Hanford Site Waste Management Plan (HSWMP) (DOE-RL 1989a) and the Hanford Site-specific plan, DOE-RL 89-10, Environmental Restoration and Waste Management Site-Specific Plan for the Richland Operations office: Detailed Information (DOE-RL 1989b). For DST wastes, disposal plans are further implemented in WHC-EP-0229, Double-Shell Tank Waste Disposal Integration Plan (Augustine 1990).

A description of the technology that must be developed to meet the reference waste management plan is provided in WHC-EP-0212-1, Hanford site Environmental Restoration and Waste Management Technology Plan (HSERWMTP) (Anantatmula 1990). One of the issues in the HSERWMTP is DST-6, Immobilization (Glass). The intent of the HSERWMTP is to eventually include al1 expense funding required to complete the HWVP Project, prepare the plant for hot startup, and submit WFQ reports for the different wastes to be processed. A preliminary : HWVP Technology Plan was prepared in 1985 as a supporting document to WHC-EP-0212, Hanford Waste Management Technology Plan (Powers 1989) (title revised to HSERWMTP for the FY 1990 version) to provide a more detailed description of the technology needed to construct and operate 
a vitrification factlity. This plan has been updated annually through 1989 [Hanford Waste Vitrification Plant Applied Technology P7an, WHC-EP-0224 (Kruger 1989)]. The title "Hanford Waste Vitrification Plant Applied Technology Plan" is used to avoid confusion with references to a broader scope of technology planning that encompasses all of the HWVP Technology activities. Figure 1-3 shows the relationship of this Plan to DOE/DP-0015, Defense Waste Management Plan (DOE 1983); the HSERWMTP (Anantatmula 1990); DOE/EIS-0013, Final Environmental Impact Statement: Disposal of hanford Defense High-Level, Transuranic, and Tank Wastes, Hanford Site, Richland, Washington (DOE 1987); and DOE-RL 89-10, Environmental Restoration and Waste Management Site-Specific Plan for the Richland Operations Office: Detailed Information (DOE-RL 1989b).

The HWVP Project, including the work described in this Plan, is dependent on other Hanfoid Site waste management activities that are not iricluded in this Plan and are outside the activities of the HWVP Project. Waste management decisions and activities particularly significant to the HWV Include the following:

- Hanford Defense Waste-EIS--The HWVP is being designed to accommodate the HDW-EIS reference alternative for disposal of DST waste. The HWVP mission can, however, be extended to handle pretreated singleshel1 tank waste, if required. A Record of Decision on the HDW-EIS was made in 1988 (DOE 1988).

Figure 1-3. Relationship of Hanford Waste Vitrification Plant Applied Technology Plan to Waste Management Documents.

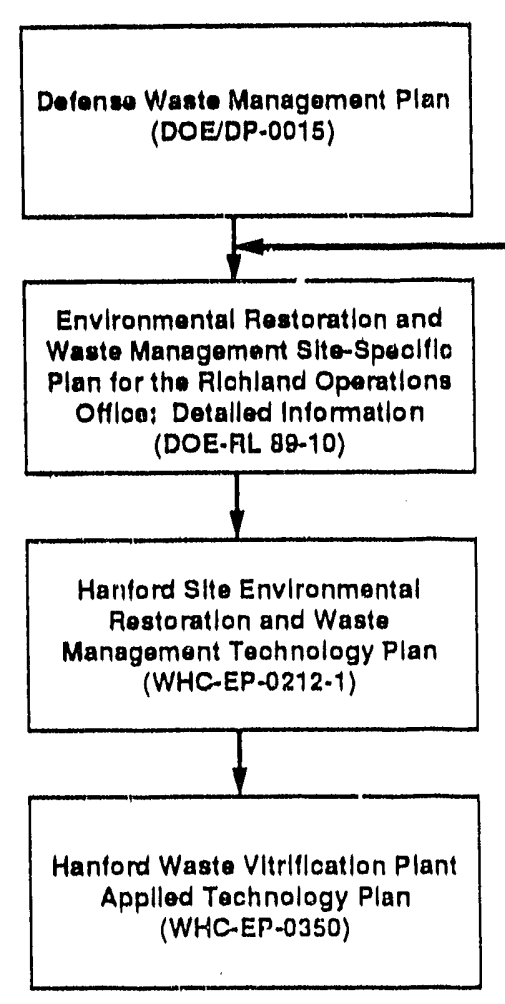

Flnal Environmental Impaot Statement: Dlsposal of Hanford Defense HIgh-Lovel, Transuranic, and Tink Wastes, Hanford $\mathbf{s} \mid t e$, Ali hland, Washington DOE/EIS-0013) 
- Characterization--The sampling and analysis of wastes to be vitrifled is requited for HWVP plant design, regulatory permitting, process development, and WFQ activities (Anantatmula 1990). This work is descrlbed under the HSERWMTP, Techntcal Is sue DST-3. Work being conducted in other HLW programs includes sampling and characterization of aging waste in tanks $101-A Z$ and $102-A Z$, which contain Plutonlum/Uranium Extraction (PUREX) Plant-generated NCAW to be pretraated at the B P1ant/AR vault. Further HWVP NCAW feed characterization will result from the $B$ Plant NCAW demonstration run scheduled for FY 1995. Characterlzation of NCRW, CC, and PFP feeds to HWVP is largely dependent on a definltive pretreatment process selection for these wastes. The posslbility exists for blending other wastes with these feed streams.

- Retrteva1--Tectinology development for DST waste retrieval is being conducted as described in Technical Issue DST-4 of the HSERWMTP. Resuspension and sluicing of accumulated sludge layers in aging waste tanks is essential so the solids can be transferred to the pretreatment facility and subsequent7y to HWVP. These are the primary activity areas for retrieval technology development work.

- Feed pretreatment--The purpose of pretreatment is to separate the waste into TRU wastes which may contain strontfum and cesium and low-level waste (LLW) fractions such that the LI.W fraction can be disposed more economically as grout. Plans are to pretreat NCAW to be vitrifled in HWVP in the AR vault in conjunction with B Plant. For the other wastes to be vitrified in HWVP, a major portion of the solids will be dissolved and processed through TRUEX treatment to enable disposal of a major portion of this waste in grout. This work is discussed in Technical Is sue DST-5 of the HSERWMTP. Pretreatment process parameters that will affect the composition of HWVP feed are pending further pretreatment flowsheet development and testing.

- Cestum and strontium capsule disposal--A study is in progress to evaluate vartous options for capsule disposal. One alternative is to remove the cesium chloride and strontlum fluoride from the capsules, dissolve this material, and pump the solutions to the tanks being used for storage of HWVP feed. If a decision is made to proceed in this direction, cestum and strontium capsule disposal would be included in the HWVP mission.

In the case of NCAW, process testing performed at B Plant during FY 1986 determined that settle/decant wi1l be the primary pretreatment process for separation of the insoluble HLW fraction (sludge) from the soluble LLW fraction. To ensure meeting the requirements of the LLW feed stream to the Transportable Grout Faclitty, subsequent ion exchange and pneumatic hydropulse fil:ition steps will further separate cestum and insoluble TRU solids from the viriW supernate and solids wash solution. Flocculating agents may be needed to shorten settle/decant time cycles, while the pneumatic hydropulse filtration step requires diatomaceous earth addition as a filter precoat and body feed. f both additives are used, they will be present in the HWVP 
feed stream along with the organtc resin used for cestum. ion exchange. Therefore, thelr concentrations and effects on feed rheology and chemlstry requitre evaluation as a part of pretreatment technology development efforts.

For the other waste types, the TRUEX pretreatment process w 111 be used to effect a reduction in the waste volume and quantity of inert waste oxides requiring vitrification. As a first step in the TRUEX process, the waste will be acldifled for dissolution of waste solids. Not all the sulids are expected to dissolve, however, and these residual soltds could constitute the bulk of the vitriflcation feed. The levels of nitrate/nitrite anions, phosphates, organics, and sodium that could impact feed redox adjustment and glass formulation chemtstry have not been determined. The concentrated TRU stream from the TRUEX solvent extraction process may also introduce high levels of organic compounds (typically oxylates) to the HWVP feed. If this situation occurs, organic concentration effects on feed rheology and chemistry may need to be evaluated in technology development tasks.

\subsection{APPLIED I'ECHNOLOGY PLAN ORGANIZATION}

This Plan is organized according to the WBS for the HWVP Project and the task management structure of the research and development contractor, PNL, which performs the major portion of the technology-related work. The WBS element 1.2.2, entitled "Vitrification System Technology Definition," has been assigned to PNL as one of several elements under the overall Westinghouse Hanford Technology WBS element 1.2. The PNL WBS element 1.2.2 has been further subdivided into five WBS sub-elements that encompass the major activities performed by PNL for the HWVP. Westinghouse Hanford Applied Technology tasks have been placed into three categorles of activities for continuity that in some cases involve more than one WBS element and are unrelated to the PNL WBS. A brief description of each of the PNL and Westinghouse Hanford Applied Technology activities is given below.

\section{Pactfic Northwest Laboratory}

- Applited technology management (WBS: 1.2.2.01)

- Perform numerous administrative activities necessary for HWVP Project validation and execution of PNL technical work

- Conduct overall PNL task management, planning, scheduling, cost control, and reporting consistent with letter of instruction (LOI) direction by Westinghouse Hanford

- Quality assurance (QA) (WBS: 1.2.2.02.)

- Implement a documented QA program speciftc to HWVP requirements including archiving of data, materials, and report records

- Provide for staff training to QA procedures, survetllance, and audit responses 
- Process development and vertfitcation testing (WBS: 1,2,2.03)

- Develop an acceptable glass composttion envelope that wlll encompass the composttion ranges of the four pretreated HWVP feed types: NCAW, NCRW, CC, and PFP

- Evaluate reactions of simulant feed with formic actd and quantify reductant requirements, combust tble offgas, and redox/ rheology characteristics

- Conduct simulant slurry feed preparation performance testing using full-scale equipment to obtain requitred destgn data and determine optlmum operating parameters for homogenelty to meet WFQ requitrements

- Conduct melter runs integrated with the full-scale slurry feed preparation system to evaluate melter and offgas system performance, provide data for design, verify melter operation within the established acceptable glass composition envelope, and provide data for WFQ to be used for process model verification and pre-validation

- Conduct a melter run in the Savannah River Site (SRS) Integrated DWPF Melter system (IDMS) to resolve destgn issues

- Obtain data for the melter offgas (MOG) system design and effictency calculations to be used for HWVP permitting

- Evaluate perforinance of the zeolite/filtration waste treatment system for recycle of TRU elements, cesfum, and strontium to melter feed

- Document technology information in an Applted Technology Handbook for engtneering reference and staff training

- Equipment adaptation (WBS: 1.2.2.04)

- Evaluate the adaptablltty of selected DWPF, WVDP, forelgn, and Hanford Site equipment and/or design features to the HWV for the full range of HWVP feeds

- Design, procure, and install pllot-scale melter(s) and waste treatment equipment for process development testing

- Conduct specific melter testing and supporting technical evaluations to assers performance of the HWVP melter using simulant NCAW feed containing noble metais including cletermining impact of minor design enhancements and predicting melter life

- Provide materials testing data necessary for design 
- Conduct studies to support equipment design and qualification of gas tungsten arc welding (GTAW) if this method of cantster closure is selected for HWVP

"Refurbtsh and modtfy ancillary equipment for process development testing

- Conduct necessary equipment feature or functlorial testing to resolve spectfic design issues

- Test the laser ablation inductively coupled plasma-mass spectrograph (ICP-MS) to determine if this analytical instrument is acceptable for direct analys is of radloact tve slurry and glass without the need for dissolution and dilution

- WFQ (WBS: 1.2 .2 .05 )

- Develop a product model that predicts glass propertles within established $11 \mathrm{~m}+\mathrm{ts}$ consistent with the strategy to be described in the Waste Compliance Plan (WCP) and Waste Qualification Report (WQR)

- Develop mass balance and product composition control system (PCCS) inodels for Implementation in the HWVP computer Management Information System (MIS)

- Verify and valtdate models through process and product testing

- Conduct radioactive bench-scale melter testing to verlfy expected slurry behavior and obtain radloactive glass for durablitty correlation with the established glass composition envelope

- Prepare radioactive glass from DST core samples, samples from pretreated pllot plant tests, and pretreated waste tank samples; evaluate durability and other properties

\section{Westinghouse Hanford Company}

- Plant equipment development (WBS: $1,2,3,01$ )

- Adapt existing technology for bar code recognttion to provide a system for tracking analytical sample vials in a shtelded cell environment

- Process testing (WBS: $1.2 .3 .01 / 1.2 .3 .03 / 1,2.5 .03$ )

- Evaluate radioactive waste shipment issues and obtafn casks for shipping radtoactive waste from the 200 Area to the 324 Butlding for radtoactive bench-scale testing

- Prequalify frit vendors and upgrade the Analytical Laboratory as approprtate to provide overcheck analys ts of frit to be recetved for HWVP operation 
- Conduct feed/melter testing using avallable equipment and faclltites at the SRS

- WFQ testing (WBS: 1.2.5.03)

- Verify compltance of HWVP Analytical Laboratory equipment With WFQ requitreliants and develop approprlate standards for analytical data compartson.

Each of these areas is addressed in a section of this document. Techntcal issues are discussed in the following format:

- Statement of issue--Spectfies the issue and indtcates th ortgin and importance

- Scope--Defines the $71 \mathrm{~m}$ ts of the issue to be addressed by the HWVP applied technology development and testing

- Status--Summartzes the current state of knowledge of vartous facets of the issue, including significant detatls of any prevtous or ongoing laboratory tests and engtneerting studies

- Remalning tasks--Lists spectfic engineering and laboratory studtes, tests, and demonstrations required to close the issue

- Schedule requtrements--Identifies issue schedule requitrements and constratnts, and key mtlestones

- Costs--Provides a summary of the est/mated cost and basts with breakdown by year to accomplish the milestones; costs are escalated to year of work performance.

Work to be accomplished by the research and development contractor, PNL, is described by an LOI tssued at the beginning of each fiscal year. A work plan, based on the LOI work description and prepared by PNL, identifies activittes, schedules, and key staff required to complete the work. Major testing activities require preparation of a test plan that discusses the tests to be performed and methods to be used for data evaluation.

Some of the milestones shown in this Plan address preparation of test plans. In some cases, the test plans will descrtbe a genertc approach to a large number of simllar experiments or have spectfic emphasts that can be used for subsequent testing over an extended pertod of time.

\subsection{SUMMARY OF MAJOR CHANGES IN THE FISCAL YEAR 1990 APPLIED TECHNOLOGY PLAN}

During early FY 1990, a melter development action plan was prepared to assess the performance of the HWVP melter for processing NCAW containing a high concentration of noble metals. Work assoctated with this assessment and subsequent evaluations has been incorporated into this update of the Plan. Also, radtoactive NCAW process testing in support of WFQ has been 
rescheduled to begin 1 year later than in the prevlous plan duo to nunavallablltty of FY 1991 funding to support development work for shtpment of radtoactlve materlal for testing. Major replanning of all applted technology work was undertaken in Fy 1990 and is reflected in this document. Table 1-2 descrtbes the changes to the list of applted technology issues.

\subsection{AUTHORSHIP}

This document has been complled from contributions made by Westinghouse Hanford a Id PNL staff working on the HWVP Project. The contribution of

D. E. Larson (PNL) in coordinating PNL input to this document is apprectated and hereby acknowledged. The cost estlmates were jolntiy produced by the Westinghoust Hanford and PNL contributors. 
Table 1-2. Changes to List of Fiscal Yean 199 Technology Plan Issues. (sheet 1 of 2)

\begin{tabular}{|c|c|}
\hline Added & Reason \\
\hline PNL. Management & $\begin{array}{l}\text { Funding support moved from Project } \\
\text { Management to Technology }\end{array}$ \\
\hline Qualtty Assurance & $\begin{array}{l}\text { Funding support moved from Project } \\
\text { Management to Technology }\end{array}$ \\
\hline Melter Performance Assessment & $\begin{array}{l}\text { Vertfy HWVP melter } 1 \mathrm{ffe} \text { for processing } \\
\text { NCAW }\end{array}$ \\
\hline Analytical Methods & $\begin{array}{l}\text { To support HWVP Analytical Laboratory } \\
\text { detafled design }\end{array}$ \\
\hline Canistered Product Qualffication & $\begin{array}{l}\text { Supports product and process model } \\
\text { validation }\end{array}$ \\
\hline Canister Drop Testing & Supports cantster procurement and welding \\
\hline $\begin{array}{l}\text { Radtoact tve Waste Shtpment } \\
\text { Support }\end{array}$ & Requtred for radtoacttve bench-scale tests \\
\hline Frtt Vendor Qualiffcation & $\begin{array}{l}\text { Support slurry-integrated performance } \\
\text { and vitriftcation testing }\end{array}$ \\
\hline
\end{tabular}

Noble Metals Analytical Methods Development

Glass Sampling Method

Noble Metals/Sludge Compatibllity Features Development

Effictency of Preliminary Decontamination

Canister Grapple Design Vertfication

Submerged Bed Scrubber Performance

Offgas Sampling Techntque Laboratory-Scale Nonradioactive Process Tests
Work being funded by Waste Management Diviston and melter performance assessment

Sampler fabrication completed in FY 1990 and subsequent evaluation to be conducted under vitrification

HWVP Project deciston to adapt. DWPF melter to accommodate noble metals

No longer design issue

Fluor responstbility

Equipment fabricated in FY 1990 and further testing incorporated into vitrification and melter offgas system tasks

Work completed in FY 1989 Incorporated into glass composition envelope definttion tasks 
Table 1-2. Changes to List of Fiscal Year 1989 Technology Plan Issues. (sheet 2 of 2)

\begin{tabular}{|c|c|}
\hline \multicolumn{2}{|c|}{ Name changes for clarity or combination of issues } \\
\hline From & To \\
\hline Glass Product Formulation & $\begin{array}{l}\text { Glass Properties and Phase Behavtor under } \\
\text { PNL WFQ }\end{array}$ \\
\hline Composttion Vartability Studies & Glass Envelope Definttion \\
\hline Melter Testing & Vitrification \\
\hline $\begin{array}{l}\text { Feed Preparation system } \\
\text { Adaptation }\end{array}$ & slurry-Integrated Performance Testing \\
\hline Melter Feed System & slurry-Integrated Performance Testing \\
\hline Slurry Sampling & Slurry-Integrated Performance Testing \\
\hline Frit Evaluation & Canister Decontamination \\
\hline Product Model Development & Product Models \\
\hline Process Model Development & Process Models \\
\hline Nonradloactive Product Tests & Glass Properties and Phase Behavior \\
\hline Radloactive Product Tests & $\begin{array}{l}\text { Radioactive Process/Product Laboratory } \\
\text { Tests }\end{array}$ \\
\hline $\begin{array}{l}\text { Bench-Scale Nonradioactive } \\
\text { Process Tests }\end{array}$ & Radioactive Bench-Scale Tests \\
\hline $\begin{array}{l}\text { Laboratory-Scale Radioactive } \\
\text { Process Tests }\end{array}$ & $\begin{array}{l}\text { Radioactive process/Product Laboratory } \\
\text { Tests }\end{array}$ \\
\hline $\begin{array}{l}\text { Bench-Scale Radioactive Process } \\
\text { Tests }\end{array}$ & Radtoactive Bench-Scale Tests \\
\hline $\begin{array}{l}\text { Ful1-Scale Nonradioactive Process } \\
\text { Tests }\end{array}$ & Slurry-Integrated Performance Testing \\
\hline WFQ Testing & $\begin{array}{l}\text { Analytical Standards and Methods } \\
\text { Adaptation }\end{array}$ \\
\hline $\begin{array}{l}\text { FY }=\text { Fiscal year } \\
\text { NCAW }=\text { Neutralized current ac } \\
\text { PNL }=\text { Paciftc Northwest Labo } \\
\text { WFQ }=\text { Waste form qual ificatt }\end{array}$ & $\begin{array}{l}\text { id waste } \\
\text { ratory } \\
\text { nn }\end{array}$ \\
\hline
\end{tabular}




\subsection{APPLIED TECHNOLOGY MANAGEMENT - PACIFIC NORTHWEST LABORATORY (WBS: 1.2.2.01)}

The program management task provides administrative, schedule, cost, and technical control of the PNL HWVP program. The following activities are performed as part of this task.

- Update PNL HWVP Project Management Plan (PMP).

- Prepare documentation and schedules for support of HWV validation.

- Prepare the PNL Work P1an.

- Estadiish and maintain the necessary procedures and organization to support identified business management requirements in an HWVP PMP and in HWVP integrating procedures. The planning and baseline management process provides for the development of technical planning and the establishment of cost, schedule, and technical baselines.

- Provide semi-annual and annual fiscal year planning input as requested by Westinghouse Hanford.

- Maintain a contractor WBS.

- Prepare, implement, and maintain a schedule in sufficient detail to plan and control discrete work as well as provide Westinghouse Hanford with a means of monitoring progress.

- Status weekly those issues identified by Westinghouse Hanford as critical to the successful completion of the Project.

- Submit monthly cost, schedule, and technical performance reports.

- Hold periodic meetings with DOE-RL and Westinghouse Hanford staff to review work progress.

- Conduct coordination meetings, as required, to discuss proposals or problems that require attention.

- Perform all aspects of administrative control and technical program management.

- Participate in Project-related technical exchanges.

- Provide response to customer-related requests for information or presentations related to HWVP Project activities.

- Issue selected technical reports for open literature publication. 
The following funding was allocated for PNL management activities (expense dollars in thousands):

\begin{tabular}{|c|c|c|c|}
\hline $\begin{array}{r}91 \\
1,160\end{array}$ & $\begin{array}{r}92 \\
1.040\end{array}$ & 93 & 94 \\
\hline
\end{tabular}

The management costs in FY 1991 include staff time needed to accomplish all activities for PNL validation as determined from a detailed cost breakdown. These costs were determined from actual costs for equivalent work in previous years with some additional staff time for maintenance of the management system that will be developed for HWVP Project validation. 


\subsection{QUALITY ASSURANCE - PACIFIC NORTHWEST LABORATORY \\ (WBS: 1.2 .2 .02 )}

The QA task supports QA program development and ensures that work performed by PNL for the HWVP Project conforms to quality standards established for the Project by DOE-RL, Westinghouse Hanford, and PNL. The QA requirements for the HWVP Project will be implemented through PNL-MA-70, Quality Assurance Manual (PNL 1989), and other applicable HWVP controlling documents. The following efforts have been established in this task to ensure efficient implementation of the PNL's HWVP Program QA responsibilities.

- QA program--Provides the planning, procedures, and documented QA program for HWVP-related activities. The PNL shall develop and implement a QA program for control of Project activities that complies with DOE Order 5700.6B, Quality Assurance (DOE 1986); DOE-RL Order 5700.1A, Quality Assurance (DOE-RL 1983); DOE/RW-0214, Quality Assurance Requirements Document for the Civilian Radioactive Waste Management Program (DOE-OCRWM 1990); and specific HWVP QA requirements.

- DOE/RW-0214 implementation--Provides for the planning, procedure development, and training for implementation of DOE/RW-0214 requirements as necessary for those activities determined to affect the waste acceptance process. The program shall be implemented to ensure that the development of data and models for use in waste acceptance process activities are verifiable.

- Audit, surveillance, and training--Provides the audit support and training associated with the implementation of QA for all tasks.

- Graded QA levels--Ensures that all work performed by HWVP conforms to the quality category criteria of DOE-RL Order 4700.1 , Project Management System (DOE-RL 1989C); and Selective Application (graded $\mathrm{QA)}$ requirements of $\mathrm{DOE} / \mathrm{RW}-0214$.

- Data archive/audit records--Ensures a copy of all data generated to prepare milestone technical reports under the LOI and/or used for calculations, analyses, or evaluations pertinent to the work sha11 be maintained in a PNL records file and available for audit or surveillance.

The following funding was allocated for PNL QA activities (expense dollars in thousands):

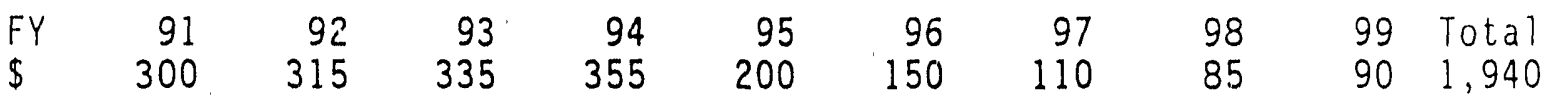

Estimated costs were determined from actual costs for equivalent work in previous years.

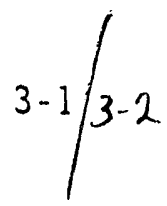




\subsection{PROCESS DEVELOPMENT AND VERIFICATION TESTING - PACIFIC NORTHWEST LABORATORY (WBS: 1.2.2.03)}

These activities provide data required for design, HWVP operation and WFO model development. Laboratory studies are performed to obtain physical and chemical property data on HWVP glass and HWVP melter feed slurries and to determine processing requirements. Pflot-scale tests are required to accomplish the following goals: verify correlation with laboratory data; establish process operating parameters and efficiencies; verify WFQ mass balance and PCCS models; determine feed preparation, melter, and offgas equipment performance; and evaluate the impact of variations in the plant feed composition, including changing to a different feed type, on process equipment operation and glass quality.

Testing of actual radioactive pretreated HWVP feed and comparison of the properties of radioactive feed with simulant pretreated feeds used in process development is part of the WFQ work described in Section 6.0 .

Flowsheets for NCRW and CC anu PFP waste pretreatment are being developed. Projected compositions for these HWVP feeds will be incorporated into the process development activities at the earliest opportunity.

Process development is divided into the following six areas:

- Waste form development

- GTass envelope definition (WBS: 1.2.2.03.01)

- Feed processing

- Redox/rheology control (WBS: 1.2.2.03.02)

- Slurry-integrated performance testing (WBS: 1.2.2.03.03)

- Vitrification (WBS: 1.2.2.03.04)

- MOG system (WBS: 1.2 .2 .03 .05 )

- Waste treatment (WBS: 1.2.2.03.06)

- HWVP Applied Technology Handbook (WBS: 1.2.2.03.07).

Funding requirements for each issue are presented with specific issue descriptions. The following funding was allocated for PNL technical planning and coordination of a 11 process development and verification testing activities (expense dollars in thousands):

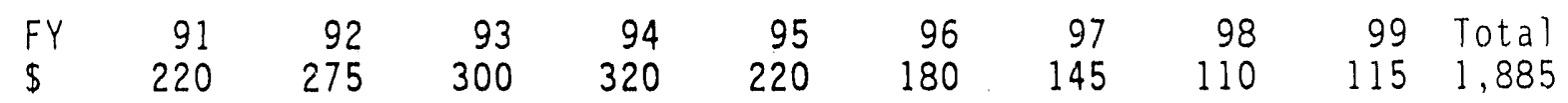

The above costs are based on actual costs for equivalent work in previous years adjusted to the overall scope of work under process development and verification testing. 
WHC-EP-0350

\subsection{WASTE FORM DEVELOPMENT'}

A glass composition envelope must be established to include the HWVP pretreated feeds (NCAW, NCRW, CC, and PFP). The envelope must meet melter processing and waste acceptance specification (WAS) requirements. The reference glasses are the nominal target compositions for glasses expected to be produced in HWVP for each waste feed type. The acceptable composition range for the combined reference glasses is determined by glass composition envelope definttion studies of specific elements in the waste that can cause the physical and chemical properties of the glass or glass melt and/or crystalline phase precipitation to change beyond established 1 imits or criteria for WFQ or glass processibility.

The glass composition envelope definttion work will provide the qualified composition region (QCR) with defined boundaries that is acceptable for glass processing. These data will be used to develop the HWVP WFQ compliance strategy, write the WQR, verify the PCCS, conduct HWVP flowsheet calculations, and establish process frit compositions and additives. Also, suitable analytical techniques need to be made available to ensure that all product composition and related property requirements can be met. Work under waste form development is performed with simulated waste slurries and glasses made from nonradioactive materials.

\subsubsection{Glass Composition Envelope Definition (WBS: 1.2.2.03.01)}

4.1.1.1 Statement of Issue. An acceptable QCR that takes into account expected variations in the HWVP feed composition with storage tank delivery and the waste source must be defined. In the glass composition envelope definition studies, the key glass components in the different. HWV feeds are combined with the frit components to develop a glass product QCR that establishes the glass composition boundaries that must be maintained to produce a product meeting the WAS and melter processing requirements. This QCR is used to determine the frit composition that will be used to process a specific waste type in HWVP and maintain sufficient flexibility to handle feed composition variations. Further development is needed to confirm preliminary established glass composition boundaries through a statistical evaluation of key glass former components.

Computer modeling to reliably predict and assess how changes in the waste composition may affect feed processibility and glass properties is an integral part of this task. The computer model will utilize glass envelope definition data to define the QCR that encompasses all HWVP feeds.

It is assumed that some of the effort required to define accepiable composition limits for glass produced from the currently known composition of the different feed types will need to be repeated as more information becomes available on the composition of samples of the CC and PFP wastes, and the NCRW. Evaluation of glass durability as a function of cooling rate may also be required.

4.1.1.2 Scope. A statistical study is being conducted un the key glass and frit components to accurately determine glass viscosity, electrical conductivity, durability, liquidus temperature, transition temperature, and 
crystallinity as a function of composition. The composition range vartations used in the statistical investigation cover the maximum and minimum concentrations expected for the key components in the HWVP melter feed and frit. This study will determine acceptable limtts for a QCR that takes into account feed compostion vartabllity.

Ten components were examined in inftial studies, and data were fitted to equations assuming linear dependency. The current investigation focuses on a non-linear (second-order) dependency evaluation of the initial 10 components with a more detalled invesitigation of the acceptable region and the envelope boundaries. Composition limits for critical components that cannot be exceeded without being detrimental to the glass were established in earlier work before initiation of the first-order statistical study.

Data from this statistical evaluation will be used to develop a computer model that predicts changes in the glass properties with composition variations of the key components. The computer model is required for WFQ and should account for analytical error and results from reference glass development on phase precipitation. This model will be used for development of a product composition control system (PCCS) that will link melter glass product to slurry feed makeup compositions. Included in this activity is the initial development of user-friendly computer visual displays of the acceptable composition envelope for use in the PCCS for plant operations.

4.1.1.3 Status. Composition vartability scoping studies were conducted on several reference glass compositions over a period of about 4 years. The following waste component oxides were investigated: zircontum, chromium, mixed alkali (1ithium, sodium, potassium), iron, aluminum, silicon, uranium, and rare earths (lanthanum and neodymium). Waste loading in the glass also was investigated as a part of these studies.

In Fy 1987, studies were initiated to evaluate waste loading and the following oxide components: barium, manganese, molybdenum, nickel, iron, calcium, fluorine, and cadmium. For this work, the viscosity was maintained within the range of 2 to $10 \mathrm{~Pa} \bullet \mathrm{s}$, and components were increased to the ir maximum limits. The test plan for detailed statistical studies prepared in FY 1987 was modified for initiation of work in FY 1989. This modification was required because of the change in approach to investigate key waste and frit components as a first-order study and to select components for second-order evaluation.

Glass studies were conducted in FYs 1989 through 1990 using the following component variables: $\mathrm{ZrO}_{2}, \mathrm{Fe}_{2} \mathrm{O}_{3}, \mathrm{Na}_{2} \mathrm{O}, \mathrm{Li}_{2} \mathrm{O}, \mathrm{MgO}, \mathrm{Al}_{2} \mathrm{O}_{3}, \mathrm{SiO}_{2}, \mathrm{CaO}, \mathrm{B}_{2} \mathrm{O}_{3}$, and Others. The Others component includes a large number of fission product oxides that have low concentrations in the waste and are not separated out as individual test variable components. The relative proportions of the components in the Others mix will be the same as in the nominal NCAW glass composition, regardless of the amount of Others to be added. Physical properties and glass characteristics being measured as a function of composition (addition or reduction of a selected component) include viscosity, liquidus temperature, electrical conductivity, phase formation (precipitation), transition temperature, and leaching rate. The test results of the first-order investigation provided the bases to develop the test matrix for the more definitive second-order study. 
Approximately 23 glasses were evaluated in FY 1989 to defitne a regton of acceptabllity and to determine if the experimental approach was viable. In FY 1990, an additional 18 glasses within the inner shell were charactertzed and planning provides for an additional 62 glasses to be evaluated in FY 1991.

4.1.1.4 Remaining Tasks. Completion of the following tasks wt11 close this issue.

- Conduct QCR laboratory studies to establish the acceptable feed component composition range for production of glass in the HWVP, document these results, and provide input for the HWVP feed processiblltty assessment.

- Expand the range of the composition envelope definttion studies to include new composition information for NCRW, CC, PFP, and other potential HWVP feeds as they become avatlable. Provide input to the statistical study database and establish acceptable processing limits for all HWVP feeds.

- Develop a computer simulation of the acceptabie glass envelope including database storage and graphic displays. Transfer this simulation to the WFQ expert PCCS model with assoctated database.

4.1.1.5 Schedule Requirements. The work that slipports the feed spectfication and flowsheet development under this issue will be completed by the end of FY 1992. The milestones 1isted in Table 4-1 were established for closure of this issue (see Summary Schedule, Figure 11-1, in Section 11.0).

4.1.1.6 Costs. The following cost breakdown was established for this issue (dollars in thousands):

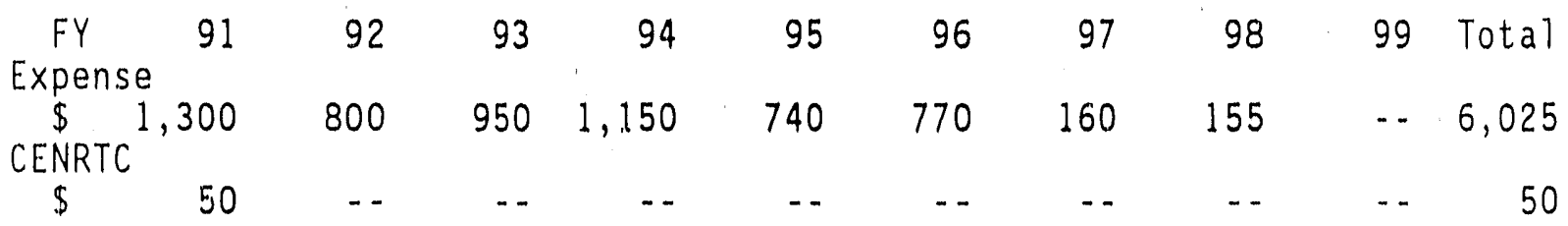

The costs for FYs 1991 to 1992 are based on detalled estimate planning completed in FY 1990. Later-year costs are estimated from the work being conducted in FY 1990 to 1992 and include characterization of an additional 100 to $150 \mathrm{glasses}$ plus computer modeling to provide modifications to the QCR from new waste composition data in out-years. Computer modeling costs are included for each fiscal year.

\subsection{FEED PROCESSING}

The HWVP feed wi11 require characterization to verify compliance with limits for the physical and chemical properties given in the Hanford Sitespecific technical data package. Incoming feed will be adjusted to ensure processibility in the feed preparation system equipment and to produce an acceptable glass product. The primary adjustments to the feed are concentration, addition of formic acid and possibly sugar (to reduce apparent viscosity and yield stress and to cuntrol the glass redox state), possible 
Table 4-1. Glass Composition Envelope Definttion Mllestone List.

\begin{tabular}{|c|c|c|}
\hline Milestone & $\begin{array}{l}\text { Completion } \\
\text { date } \\
\text { (quarter/FY) }\end{array}$ & Mllestone description \\
\hline 1 & $2 / 1991$ & $\begin{array}{l}\text { Issue glass envelope computer modeling users } \\
\text { development based on first.order study }\end{array}$ \\
\hline 2 & $4 / 1991$ & $\begin{array}{l}\text { Complete base case QCR definition and provide } \\
\text { data for preliminary feed processibllity } \\
\text { assessment }\end{array}$ \\
\hline 3 & $4 / 1991$ & $\begin{array}{l}\text { Provide preliminary computer simulation of } \\
\text { the glass QCR using avatlable data }\end{array}$ \\
\hline 4 & $4 / 1992$ & $\begin{array}{l}\text { Provide definttion of the QCR for HWVP feed } \\
\text { spectfication and feed processing evaluation }\end{array}$ \\
\hline 5 & $4 / 1993$ & $\begin{array}{l}\text { Complete computer simulation of glas QCR } \\
\text { based on the glass composition envelope } \\
\text { definttion database }\end{array}$ \\
\hline 6 & $4 / 1995$ & $\begin{array}{l}\text { Provide update of the glass QCR for all HWVP } \\
\text { feed types to be used for feed spectfication } \\
\text { and PCCS }\end{array}$ \\
\hline 7 & $4 / 1996$ & $\begin{array}{l}\text { Complete all the glass envelope definition } \\
\text { studies }\end{array}$ \\
\hline 8 & $4 / 1996$ & $\begin{array}{l}\text { Complete development of computer program and } \\
\text { graphic displays for waste form evaluation } \\
\text { and control }\end{array}$ \\
\hline 9 & $4 / 1998$ & $\begin{array}{l}\text { Complete transfer of glass envelope } \\
\text { definition computer software to HWVP MIS }\end{array}$ \\
\hline
\end{tabular}

PCCS = Product composition control system

QCR = Qualified composition region

MIS = Management Information system

addition of a foaming inhibitor to the slurry, and digestion. Proper redox control of the slurry feed is essential for successful HWVP melter operation to prevent the melt from foaming and to prevent sludge formation in the melter. If the redox state of the feed is oxidizing, the melter glass could release gases that would form a foam and reduce the melter feed processing rate. If the redox state of the feed is too reducing, melallic or secondary phases could form, thus possibly distorting electrical current paths in the melter glass, compromising product quality, and eventually leading to melter fallure. The redox state of the melter feed is affected by the incoming waste composition and by adjustments made during feed processing. 
Melter feed makeup processing includes addition of fresh frit slurry, canister decontamination frit, and recycle waste, followed by additional concentration. Laboratory studies have been conducted to study feed processing and composittonal vartations and to measure physical, chemical, and rheological properties during concentration and reaction with formic acid. The amnunt of reductant (formic acld/sugar) needs to be determined as a function of chemicals (nitrate, nitrlte, organtc, and to a inter exterit, sulfate, phosphate, and some metal cations) in the feed that can affect glass redox. Also, offgas generation during forinating needs to be charactertzed to evaluate possible safety hazards and control of effiuent concentrations.

Sugar provides more reductant per unit volume addition than formlc actd and may be required for processing feeds that are near the $11 \mathrm{~m}$ tts of the nitrite/nitrate spectfication. For these feeds, the formic acid consumption may exceed the design basts. Sugar addition offers processing flextbiltty for plant operation.

Full-scale feed system equipment will be installed in FY 1990-91 to conduct slurry-integrated performance testing (Section 4.2.2). This equipment also will be used to support melter runs (Section 4.3). The results of work conducted in FY 1991 will be used to evaluate the sultabllity of the DWPF slurry feed system equipment for processing Hanford Site wastes. The equipinent will be used to evaluate WFQ requirements, develop control logtc for plant operation, and investigate the behavior of the simulant NCAW, NCRW, CC, PFP, and other feeds.

The following subsections descrlbe issues that must be resolved to determine allowable limits for additions of formlc actd and sugar to control glass redox and operational requirements for full-scale feed preparation, equipment.

\subsubsection{Redox/Rheology Control (WBS: 1.2.2.03.02)}

4.2.1.1 Statement of Issue. Studies are requtred to close several issues that may impact the HWVP design and operation. Specific design issues are as follows: generation rates for hydrogen, reactions related to formation of nitrogen oxides and other gases during formating, and potentlal for nitrate salts exothermic reaction in feed-processing tanks. A brtef description of the issues is provided below.

- Reducing agent requitrements--Recent laboratory testing information shows that the amount of nitrate in the feed w111 have a major impact on the formic actd addition needed to control melter glass redox. Nitrite in the feed will also have a simtlar influence. The full range of HWVP feed components needs to be evaluated to determine reductant consumption requitements, confirm the HWVP formtc acid tank capactty, and develop a redox control reducing agent procedure for HWVP operation. Although some increase in formic acid requitrements can be acconmodated in the current HWVP design, there are 1 imitations. Key ttems that need to be addressed are as follows: (1) a firm design basis nominal and maximum reducing agent requirement (formic actd and/or sugar) that takes 
Into account the upper 1lmit to which sugar can be used as a substitute for formic actd without causing reducition in the meilter glass production rate, and (2) a technical bases for formlc acid addition that covers the fuil range of the HWVP feed speciftcation including volatile anton content.

- Gas generation rates-..previous laboratory-scale testing indicates that gas generation rates during formating are a strong function of the quantlty and rate of formic actd addition. Key issues that remath are as follows: (1) effect of feed composittion (noble metals, ittrate/nitrite, others) on gas generation rates: (2) effect of formic actd consumption (quantity and addition rate) on total gas generated and generation rates; and (3) gas generation rate peak(s) and pertod during formating cycle at which peak(s) occur.

- Effect on noble metals-iNoble metals are belleved to be a catalyst for some formating reactions. Investigation of the effects of noble metals on feed preparation chemistry at laboratory-scale is, therefore, particularly important. Because most of the full-scale tests wlll be made without noble metals, data are required to predict how the lack of noble metal feed constituents may blas full-scale performance results.

- Nitrate salts exothermic reaction- - A relatively large quantity of organic-reducing agents are added during feed preparation. An accident has been postulated in a preliminary safety analysis report whereby reducing agents, in combination with nitrate/nitrite salts, dry out, form an exothermic mixture, and subsequently selfignite due to radfolytic heat. To ascertain whether the accident is credible, the following information is required: (1) behavtor of nitrate/nitrite and/or reducing agents durtng the feed preparation cycle (1t is posstble that the bulk of these spectes could be consumed by liquid phase reactions before the solids could dry out); (2) reaction rates for decomposition of formate and sugar as a function of $\mathrm{pH}$, composition, and temperature (espectally at a neutral to alkaline $\mathrm{pH}$ ); (3) degree to which organic nitrates form as a function of $\mathrm{pH}$; and (4) if soltds do dry out, is detonation possible.

- Melter redox control--Testing at SRS and WVDP in FYs 1989 and 1990 has shown that control of melter glass redox w 111 be more difficult than previously thought. Correlation of feed sample redox measurements with the redox state of melter glass will require further development. Redox measurement methods must be suttable for application in the HWVP Analytical laboratory hot cells and development studies must cemonstrate correlation of data in conjunction with melter verffication testing.

4.2.1.2 Scope. The amount and type of reductants requitred for feeds with different compositions to achieve acceptable redox must be determined through laboratory- and pllot.scale testing. Formic witd and sugar addittons are made to vartous feed compositions, including noble metals additions, and the redox potential is evaluated by making glass from the feed and deternitning 
the $\mathrm{Fe}^{+2} / \mathrm{Fe}^{+3}$ or $\mathrm{Fe}^{+2} / \mathrm{Fe}$ ratto. The rationale of when to use sugar to supplement the use of formlc acld also must be established and these results wlll be used to verify the capacitiy of the HWVP formic acld storage vessel.

Studles to evaluate nitrate salt exothermic reactlons will probably use differential thermal analysis laboratory apparatus for determining the reaction temperature and rate of energy release.

4.2.1.3 status. Work is in progress at DWPF and WVDP to develop methods for control of the redox state of glass in the melter by testing the formated foed slurry samples and to obtain a better understanding of vartous factors that affect a correlation test. The PNL has completed laboratory studies using the reference NCAW composition feed simulant to determine the feed redox state as well as the rheological and physical properties of the feed after each processing step. The melter feed $\mathrm{Fe}^{+2} / \mathrm{Fe}^{+3} \mathrm{ratto} \mathrm{pH}$, and calculated percent of stotchiometric addition of formlc acid were evaluated. Results indicated that the $\mathrm{Fe}^{+2} / \mathrm{Fe}^{+3}$ ratio was the most conventent approach to assess glass redox state. The results also indicated that formlc actd addition can be used to matntain an acceptable redox range and signiffcantly improve the feed rheology for the reference NCAW feed.

Laboratory studies conducted in FYs 1989-90 denionstrated that carboriate content in the feed did not affect glass redox. The nitrate content in the feed substantially affected redox reactions and addition of 3 to 4 mols of formlc acid per mol of nitrate was necessary to achleve an acceptable redox state in the glass. This work also showed that hydrogen and ammonta are generated during feed formating and the potentlal for an explosive mixture of these gases must be considered for the HWVP process vessel verit system design.

\subsubsection{Remaining Tasks. Completion of the following tasks will close this} is sue.

- Determine the offgas composition and generation rate as a function of formic actd/sugar addition rate and amount with and without noble metals in the NCAW feed.

- Conduct studies to determine the affects of nitrite, organics, and to a lesser extent, sulfate and phosphate, in HWVP feeds on glass redox, and determine the amount of formic actd and/or sugar addition necessary to achieve acceptable glass redox, considering al? important redox-sensitive components.

- Correlate data obtained from laboratory testing of melter feed with actual redox of glass in the melter.

- Determine behavtor of nitrate/nttrtte and reducing agents cluring feed preparation and decomposition reaction rates of formate, sugar. and organic nitrates as a function of $\mathrm{pH}$, composition, and temperature.

- Compare redox state and rheological properties of the radioactive waste with those of simulated waste. 
- Conduct studtes to assess rhoological and redox properties of CC, PFP, and NCRW feeds and to define the relationship between the reductants in the feed and the glass redox state.

- Develop process giddel thes on when to use sugar addition to sipplement formlc actd addition for melter glass redox control.

4.2.1.5 Schedule Requirements. This issue supports slurry-integrated performance testing, vitriftcation, and MOG system tasks that are important for preparation of HWVP feed spectfications and feed pretreatment requtrements. Scoping information for NCAW feed was obtained in FYs 1987 through 1990. The milestones 1isted in Table 4-2 were establtshed for closure of this issue (see Summary Schedule, Figure 11-1, in Section 11.0).

4.2.1.6 Costs. The following cost breakdown was established for this issue (expense dollars in thousands):

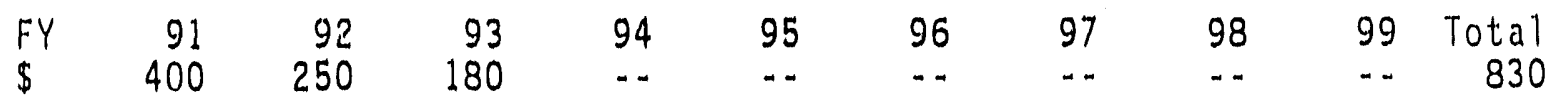

The above estlmated costs are based on actual costs for simflar work and the estimated staff time reeded to close this issue.

Table 4-2, Redox/Rheology Control Milestone List.

\begin{tabular}{|c|c|c|}
\hline Milestone & $\begin{array}{l}\text { Completion } \\
\text { date } \\
\text { (quarter/FY) }\end{array}$ & Milestone description \\
\hline 1 & $1 / 1991$ & $\begin{array}{l}\text { Issue test } p l a n \text { for reductant requilrements } \\
\text { and exothermic reaction studies }\end{array}$ \\
\hline 2 & $3 / 1991$ & $\begin{array}{l}\text { Complete laboratory studies to determine } \\
\text { reductant requirements, gas generation rates, } \\
\text { and exothermic reaction impacts }\end{array}$ \\
\hline 3 & $2 / 1992$ & $\begin{array}{l}\text { Issue test } p l a n \text { redox/rheology studies of } \\
\text { NCRW, CC, and PFP feeds }\end{array}$ \\
\hline 4 & $4 / 1992$ & $\begin{array}{l}\text { Complete NCRW, CC, and PFP feed redox/ } \\
\text { rheology scoping studtes }\end{array}$ \\
\hline 5 & $4 / 1993$ & $\begin{array}{l}\text { Provide correlation of slurry vitrification } \\
\text { testing with melter glass redox for HWVP } \\
\text { operation }\end{array}$ \\
\hline
\end{tabular}

CC $=$ Complexant concentrate
NCRW $=$ Neutralized Cladding removal waste
PFP $=$ Plutontum Fintshing Plant




\subsubsection{Slurry-Integrated Performance T'esting (WBS: 1.2.2.03.03)}

4.2.2.1 statement of Issue. The expected ranges of all foed propertles are needed for HWVP equipment design and operation spectfications. Slurry properties wlll vary as dflute feed is recelved and concentrated in the slurry recelpt and adjustment tank (SRAT) and formic actd is added to adjust redox. The addition of frit in the slurry mix evaporator (SME) will cause further changes in the slurry charactertstics. Properties of most concern are weight percent solids and oxides, slurry density, apparent viscostty as a function of shear rate, yield stress, settled solids shear strength, and settling rate. The range of vartation of these properties with changes in feed composition must be determined to ensure the feed property spectfications being used for design of the HWVP equipment are sufflctent for processing al1 required feed types. Pressure drop data for different diameter 1 ines transporting frit slurry are needed at an early date for HWVP design.

For design verffication, the propertles of radjoactive feeds taken from waste tanks need to be compared to the properties of simulant feeds used for testing. Correlation of these data will be accomplished under WFQ radtoactive testing tasks to provide the technical link to the extenstve full-scale tests being coriducted on simulant waste compositions.

Current HWVP design is based on adaptation of the DWPF melter foed preparation system to the HWVP. Testing of melter feed preparation system major full-scale components has been completed for the DWPF. Use of this system in the HWVP requires an evaluation of DWPF technology for applicability to HWVP performance requirements and cunditions. Selected HWVP testing is requitred to verify component performance where engineering analyses are not adequate to verffy that the equipment will meet HWVP performance requirements.

Prototyplc full-scale melter feed preparation system equipment will be tested in conjunction with the LFCM and a plant prototypic glass melter. Data obtained from integrated testing using this feed preparation system and plant prototypic melter starting in FY 1994 are needed to provide information for design verification, WFQ process model pre-validation prior to programming the HWVP computer systems, and planning for HWVP cold-run testing.

The reference DWPF pump system for slurry transfer from the melter feed tank (MFT) to the melter uses a vertical cantilevered-shaft centrifugal (VCC) pump and circulating loop. Melter feed is drawn off at a rate controlled by the loop pressure. This system was adapted by HWVP after testing by DWPF, but the design was modified to reduce plugging potential by decreasing the distance from the crossflow filter to the melter. The design modification has not been demonstrated and may have different operating characteristics from the DWPF design. Demonstration of the reference system for HWVP is needed to support design. Periodic feed pump trips and melter feed line plugging are a concern for HWVP because resultant line flushing would dilute the melter feed. Feed pump impeller wear also is a concern because operating 1 tfe may not be much longer than 6 months.

Representative HWVP tank slurry samples must be taken to characterize HWVP process streams for process control, accountablitty, and WFQ. Work is continuing at DWPF to verify sampling system rellablitty and error for slurry and slurry/frit samples. The ability to obtain representative HWVP slurry 
and slurry/frtt samples is affected by pretreated and concentrated sludge rheological properties and the varlations of tire frit composttion within the acceptable envelope. Thus, the operablltty and performance of the sampling system should be vertfted, in support of destgn, for HWVP feeds and frit slurrtes that may have different sampling charactertstics than DWPF slurrtes.

Performance behavtor of interest tncludes the following characteristics:

- Pressure drop in lines transporting slurry frit as a function of line diameter (destgn-spectfic data)

- slurry mixing homogenelty as a function of agttator. speed and agttator power requirements (dependent on slurry and frtt particle properties)

- Slurry mixing homogenetty for a partially filled feed preparation vessel

- Melter feeding including cross-flow fllter strainer performance and feed loop pressure

- Heat transfer coefficlents, bol1-off rate, and impact of tank and component surface fouling (slurry-spectfic data)

- Soltds behavior (lump formation and caking), cleaning, and resuspenston including tank pertphery solids buildup and use of water and water/nitrtc actd (dilute concentration) for coll cleaning

- Foaming in the SRAT as a function of agttation rate and formic actd addition rate (slurry-specific data) including evaluation of antifoam agents, if needed

- Scale-up verffication from laboratory tests of gas generation during and after formic acid and sugar addition including measurements of $\mathrm{H}_{2}, \mathrm{NH}_{3}, \mathrm{~N}_{2} \mathrm{O}, \mathrm{NO}, \mathrm{NO}_{2}, \mathrm{CO}_{2}, \mathrm{CO}$, and $\mathrm{N}_{2}$ at a mintmum for safety and permitting see Section 4.2.1 for a laboratory parametric study description)

- Slurry sampling characterization

- Condenser heat transfer coeffictent, fouling potential, and decontamination factors (DF) as a function of slurry height in the SRAT/SME vessel including noricondensible effects on condenser performance

- Slurry transfer and dilution

- Melter feed pump impeller, tank, tank coll, and agitator erosion (Section 5.4)

- Three-way feed line flush valve rellabllity

- Tank heels after slurry transfer as a function of agttator revolutions per minute 
- Slurry-level detection accuracy, precision, and reliability.

4.2.2.2 Scope. The HWVP process siurry (after each processing step) physical, chemical, and rheological data necessary for evaluation and performance verification of the feed preparation system equipment will be provided. A prototype full-scale SRAT/SME/MFT will be operated to validate feed preparation equipment performance and processing time. The scope of this task includes the following activities.

- Evaluate DWPF data and obtain additional data by testing to evaluate feed preparation system performance and resolve design issues.

- Determine operating characteristics of the melter feed system using HWVP simulant feeds.

- Conduct engineering evaluations of the full-scale feed preparation system as required for design verification.

- Define testing required for verifying performance of the HWVP melter feed preparation system.

Testing of the following equipment systems is included in this issue:

- SRAT, SME, and MFT

- Melter feed pump and delivery loop, including cross-flow filter, flow restrictor, melter feed nozzle, and three-way flush valve

- Feed vessel tank condenser

- Slurry-level detector

- Slurry sampler.

Nonradioactive simulated waste must be characterized by measuring the physical and rheological properties for each processing step in the feed preparation flowsheet. Data obtained from measurements of the rheological properties of the radioactive feed also will be compared to data obtained on simulant feeds to verify HWV feed preparation equipment processing capabilities.

Initial feed processing studies will be conducted on simulant NCAW. This work will be extended to NCRW and the CC and PFP wastes to be processed in HWVP to ensure efficient and reliable equipment operation. Support of the melter runs, including sampling and analysis of the slurries, is included in the scope of work under this task.

4.2.2.3 Status. Studies conducted for the DWPF showed that formic acid, when added to SRS waste as part of the mercury separation process, reduces the apparent viscosity and yield stress of the feed and eliminates the problem of glass foaming in the melter. Therefore, addition of formic acid in the range of 70 to 120 percent of the calculated amount necessary for complete reaction with components in the waste slurry has been included as part of the DWPF process. 
Studies of the rheological and physical properties of simulant HWVP feeds were conducted using laboratory- and pilot-scale systems from FYs 1985 to 1988. These feeds were prepared by blending the hydroxides of the various feed components or by precipitation of major components from nitrate solutions and addition of minor component hydroxides. Resulting waste slurries and melter feeds were found to exhibit an increasing yield-pseudoplastic behavior during concentration. The apparent viscosity and yield stress of HWVP feeds were found to be reduced by the addition of formic acid.

During FYs 1986 and 1987, multivariable feed processing tests were completed. The rheological and physical properties of simulated HWVP reference feed were examined during processing, while varying the following process variables:

- Amount of formic acid addition

- Concentration level before formating

- Degree of agitation

- Degree of aging.

The first three variables were found to significantly affect the feed rheological properties. Aging unagitated melter feed samples for 14 days did not significantly change rheological properties.

In FY 1988, the reference NCAW simulant feed was prepared by precipitation from nitrate solutions by a commercial vendor according to a feed preparation specification established for all subsequent HWVP work. Processing characteristics of this feed were evaluated during the pilot-scale ceramic melter (PSCM)-23 run. Studies indicate the rheological and physical properties of the feed will stay within the ranges specified in the technical data package for the HWVP.

Feed characterization work in support of the LFCM and plant prototypic melter runs is a major part of slurry-integrated performance testing. Information obtained from this support work will add to the database of feed properties established from previous work.

Significant pump and melter feed loop development has been performed and reference equipment/systems have been selected for the DWPF. A long-term (6-month running time) pump test was performed to demonstrate adequate performance of the VCC pump for DWPF operations. Work is continuing at DWPF to evaluate pump and melter feed loop operating characteristics and reliability.

The DWPF feed preparation system has been designed, and the equiprnent has been installed in trie plant. Preparations are being made to test the DWPF equipment. Major elements of the DWPF melter feed preparation system requiring testing (including dry frit handling/storage, frit slurry makeup/ transfer, SRAT, SME, condensers and melter feed pump loop) have been, or are being, tested full-scale by DWPF staff. A series of technology exchanges have transpired and transfers of data and experience to the HWVP staff are continuing. 
A full-scale SRAT/SME is being installed for testing in the 324 Building High Bay. Equipment procurement was initiated in FY 1989 and scheduling indicates the testing capability witl be available about mid-FY 1991.

The design approach for the frit handling and process systems for HWVP will not be the same as for DWPF; however, no issues have been identified that require evaluation of this equipment for HWVP.

Because of the importance of sampling to process control and WFQ, a decision was made in FY 1989 to obtain a prototypic DWPF sampling system for testing in conjunction with the full-scale feed preparation system. The sampling system was procured in FY 1989 and installed in FY 1990.

\subsubsection{Remaining Tasks. Completion of the following tasks will close this} issue.

- Prepare NCAW, NCRW, CC, and PFP simulant slurry feeds and perform tests to determine physical and rheological properties at various processing stages using the full-scale feed preparation equipment in conjunction with, and in support of, melter runs (the full-scale SRAT/SME/MFT test vessel will be available for this purpose in FY 1991).

- Perform full-scale feed preparation system testing to resolve the issues discussed in Section 4.2.2.1.

- Continue to support melter runs through FY 1999.

- Conduct a technical evaluation of the HWVP prototypic feed pump installed in the full-scale feed preparation system. Evaluate operating performance and assess methods to reduce tank dilution from line flushing.

- Evaluate available data pertinent to the DWPF slurry feed preparation system performance, in context with HWVP development data and equipment design criteria, to determine DWPF equipment applicability to HWVP.

- Conduct operational testing of a melter feed preparation system consisting of a full-scalle prototypic SRAT/SME/MFT process tank, condenser, agitator, transfer pump, sample system, melter feed system, heat transfer coils, and associated instrumentation including prototypic level and temperature detection together with supporting tankage.

- Evaluate operation of the feed preparation equipment using a Micon DCS.

- Complete testing of the HWVP prototypic sampler in conjunction with the homogeneity evaluation of the SRAT/SME/MFT vessel. The lines from the full-scale feed vessel to the sampler should be equivalent to the placement of the SRAT and SME in the HWVP.

- Maintain, refurbish, and provide spare parts for a full-scale feed preparation system. 
Testing performed in FY 1991 and later years will be in support of process development and WFQ activities.

4.2.2.5 Schedule Requirements. The NCAW run must be complete by the end of FY 1991 to support process equipment definitive design. The milestones listed in Table 4-3 were established for closure of this issue (see summary Schedule, Figure 11-1, in Section 11.0).

Table 4-3. Slurry-Iritegrated Performance Testing Milestone List.

\begin{tabular}{|c|c|c|}
\hline Milestone & $\begin{array}{l}\text { Completion } \\
\text { date } \\
\text { (quarter/FY) }\end{array}$ & Milestone description \\
\hline 1 & $2 / 1991$ & $\begin{array}{l}\text { Issue test plan for feed preparation system } \\
\text { evaluation }\end{array}$ \\
\hline 2 & $3 / 1991$ & $\begin{array}{l}\text { Complete feed preparation equipment } \\
\text { installation and acceptance testing }\end{array}$ \\
\hline 3 & $4 / 1991$ & $\begin{array}{l}\text { Complete testing to resolve Definitive } \\
\text { Design and feed processing issues }\end{array}$ \\
\hline 4 & $4 / 1992$ & $\begin{array}{l}\text { Complete evaluation of feed processing and } \\
\text { equipment performance issues related to HWVP } \\
\text { Definitive Design }\end{array}$ \\
\hline 5 & $4 / 1992$ & $\begin{array}{l}\text { Complete studies of SRAT/SME/MFT mixing } \\
\text { characteristics (vessel homogeneity and } \\
\text { sampler error) as a function of operating } \\
\text { variables for the WQR }\end{array}$ \\
\hline 6 & $1 / 1993$ & $\begin{array}{l}\text { Issue test plan for use of feed preparation } \\
\text { system to support melter runs }\end{array}$ \\
\hline 7 & $4 / 1993$ & $\begin{array}{l}\text { Verify feed preparation system operating } \\
\text { characteristics and reliability for HWVP } \\
\text { readiness review and qualification runs }\end{array}$ \\
\hline 8 & $3 / 1994$ & $\begin{array}{l}\text { Replace feed preparation system components } \\
\text { (agitator, coils, etc.) as necessary in } \\
\text { support of plant prototypic melter runs }\end{array}$ \\
\hline 9 & $4 / 1996$ & $\begin{array}{l}\text { Complete evaluation of NCAW, NCRW, and CC } \\
\text { and PFP waste (feed envelope range) } \\
\text { processing for WFQ process modeling } \\
\text { development, validation, and implementation } \\
\text { in the HWVP MIS }\end{array}$ \\
\hline
\end{tabular}

MFT = Melter feed tank

SME = Slurry mix evaporator

SRAT = Slurry receipt and adjustment tank

WFQ = Waste form qualification 
WHC-EP-0350

4.2.2.6 Costs. The following cost breakdown was established for this issue (expense dollars in thousands):

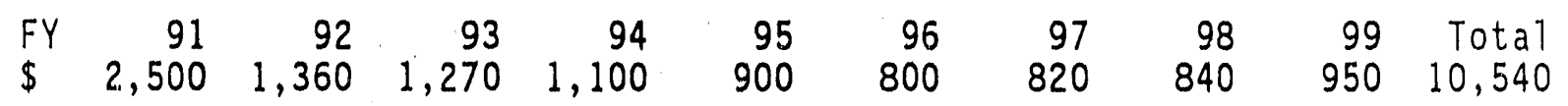

The FY 1991 to 1999 costs include estimated staff time required to accomplish the scope of work for each year and provide analytical support. The FY 1991 cost is higher than for other years because completion of system installation, system startup, and extensive sampling and analysis are planned. The latter effort is needed to evaluate mixing characteristics of the ful1scale feed preparation system.

\subsection{VITRIFICATION (WBS: 1.2 .2 .03 .04 )}

Melter testing is supported by work being conducted under the process development, equipment adaptation and testing, and WFQ tasks. Estimated costs identified for melter runs include only those activities associated with feed procurement, melter operation, and limited sampling of the feed, glass, and offgas system waste to operate the melter and provide a mass balance to demonstrate that acceptable processing conditions and WFQ test requirements are being met. Additional efforts needed to support the melter runs are as follows:

- STurry-integrated performance testing (Section 4.2.2)

- MOG system (Section 4.4)

- Waste treatment (Section 4.5)

- Process model development (Section 6.1.2)

- Canistered product qualification (Section 6.2.2).

To provide the information described in this section, a full-scale feed preparation system must be available for operation in FY 1991, and a plant prototypic glass melter must be ready for operation in FY 1994. Also, a 1/10-scale melter is being fabricated and will be available for operation in FY 1991.

The HWVP is scheduled to vitrify pretreated feed streams of NCAW, NCRW, and CC and PFP wastes. Vitrification development work on the NCAW has been underway since 1984. Characterization efforts on the NCRW, and CC and PFP wastes began in FY 1990, and vitrification studies will continue through FY 1999.

Each feed type will have a different chemical and oxide composition and require pilot-scale testing. Vitrification testing will provide mass balance data, demonstrate integrated performance with the feed preparation and offgas systems, establish acceptable solids loading limits, determine nominal and maximum melter processing rates, and provide offgas treatment system effictency data. Planned runs will provide data for the WFQ mass balance model (MBM), canisters for product modeling, composition evaluation, and PCCS 
verification, and operating parameters for HWVP startup, readiness review, and qualification runs. It is anticipated that plant operating procedures will be prepared and used for the plant prototypic glass melter testing runs and that Westinghouse Hanford staff will participate in equipment operation.

\subsubsection{Statement of Issue}

In 1989, the reference melter was changed from the modified WVDP melter to the DWPF melter; and the reference plant capacity was increased from $45 \mathrm{~kg} / \mathrm{h}(100 \mathrm{lb} / \mathrm{h})$ to $100 \mathrm{~kg} / \mathrm{h}(220 \mathrm{lb} / \mathrm{h})$ of glass. Testing is necessary to verify that the design capacity can be achieved with all HWVP feed types in a DWPF melter.

Variables that must be evaluated include the following: (1) the effect of plenum ( $1 i d$ ) heaters on offgas composition and associated offgas treatment equipment performance; (2) the effects of feed rate, plenum temperature, me1t temperature, and glass composition on melter performance including differential pressure pouring, potential bridging, offgas composition, and offgas decontamination factors; and (3) the effects of glass redox state on crystalline and metallic second-phase formation/accumulation. Melter through-put rate must be verified with variations of the waste oxide components within the range established for the QCR. The amount of total organic carbon (TOC) in the feed that can be processed in the melter without exceeding the established limit for glass redox must be determined to provide limits in the feed specification.

Melter operating characteristics must also be verified for processing feed containing HWVP recycle components (zeolite and diatomaceous earth). Sampling of the feed, in conjunction with the output glass, is needed to verify the WFQ process models.

The glass sampling requirements in support of WFQ were defined in FY 1988 to be one sample for every MFT batch. A sampler developed for DWPF is located in the canister throat protector and operated by a manipulator. Testing is required of the DWPF manual operation glass sampler during melter runs to verify the design. Currently, proposed requirements for glass sampling in HWVP are significantly greater than the number of samples per year proposed by DWPF and further assessment is needed to provide a strategy for HWVP consistent with glass sampling and analysis capabilities planned for HWVP.

\subsubsection{Scope}

This issue includes nonradioactive melter testing required to verify melter design, feed vitrification, and the glass QCR boundaries. Melter tests were conducted in the PSCM during FY 1988 to support the characterization of the reference offgas treatment system. Melter runs in FYs 1991 to 1999 wi11 use the full-scale feed preparation test system to verify process performance, establish operating specifications, and obtain WFQ model input data and integrated test data for HWVP process qualification runs. 
Current plans are to conduct an LFCM run in FY 1991 to evaluate the full-scale feed preparation system and obtain processing data. The LFCM will be modified to include plenum heaters and differential pressure pouring as specified for the HWVP reference melter. This melter will be used for subsequent testing in FYs 1991 through 1993.

Plans call for installation of a plant prototypic melter (approximately $1 / 3$ - to 1/2-scale) with an appropriate scale offgas system in the 324 Building High Bay area by the end of FY 1993. Testing will be initiated in FY 1994 with simulant feeds to provide data for WFQ and to define the test matrix for. HWVP qualification cold testing. These runs will include feeds with compositions designed to simulate the feed specification 1imits for NCAW, NCRW, and CC and PFP wastes. At a minimum, feed compositions that will form high-and low-viscosity glasses and contain high-and low-volatile anton content will be tested for each specific waste type. Completion of testing under this task is dependent on obtaining capital equipment not related to construction (CENRTC) funding for a new plant prototypic melter as discussed in Section 5.1.

A 1/10-scale melter with electrode configuration based on the HWVP reference melter design was fabricated in FY 1990 to provide a capability for testing feed containing noble metals (Section 5.5.1) and to evaluate a wide range of feeds throughout the QCR. Subsequent planning has led to the noble metal tests being conducted in the FRG, or at the SRS IDMS facility. Therefore, the 1/10-scale melter will be used to evaluate processing of the various HWVP feed types at the maximum limits of the QCR. These types of tests will be conducted at 1/10-scale before pilot-scale melter testing to verify that sludge will not accumulate and cause melter fallure or otherwise impact melter operations. These tests will be initiated in FY 1992.

A glass sampler, capable of taking one glass sample per canister, was successfully tested at the SRS. A similar glass sampler was designed and constructed in FY 1990 for HWVP testing with the LFCM runs. This sampler wil1 be used to demonstrate glass sampling for process analyses, WFQ, and operational demonstration. Current planning also provides for FY 1991 procurement and installation of a prototypic reamer/brush in the LFCM offgas 1 ine for periodic removal of glassy deposits that may form on the film cooler surface. This equipment will be tested in FY 1991 and further evaluated during an extended LFCM run in FY. 1992 and subsequent melter runs in the following years.

The PNL applied technology budget for FY 1991 includes funding for a test in the IDMS at the SRS. The IDMS is being considered as an option for obtaining early design data and/or for conducting melter testing with simulant feed components that cannot be evaluated in the 324 Building facilities.

\subsubsection{Status}

The HWVP offgas data related to the HWVP reference offgas system were collected during four melter tests conducted since FY 1985. T'wo of these tests were conducted in the high-bay ceramic melter (HBCM) where offgas testing is limited to determining melter DFs. The other two tests were 
conducted in the PSCM. A 20-day PSCM run in 1988 obtained base destgn data on the reference offgas system under normal melter operating condttions, 1.e., with 80 to 90 percent cold cap coverage of a glass surface (Goles et a1. 1990). In addition, testing with simulated waste (NCAW'87) and frit provided process characterization data to support new reference feed and glass compositions.

In FY 1986, two experiments that used a smaller, engtreering-scale melter (ESM) were conducted to determine the effects of solids loading and spectfic composition varlabilities on melter processing. Three oxtde loadings and three compositions were tested. Results indicated that maximum glass production rates were obtained at a slurry oxide loading of about $500 \mathrm{~g} / \mathrm{L}$ $(4.2 \mathrm{lb} / \mathrm{gal})$. No effect on processing rate was observed for the three composition variables of the NCAW tested (high sodium, high zircontum, and low iron).

Data from previous melter tests in support of varfous programs were complled during FYs 1987 to 1989 to consolidate offgas information for use by HWVP. The PSCM and individual component testing defined offgas treatiment system capabilities and provided data for evaluation of the HWVP melter design.

\subsubsection{Remaining Tasks}

Completion of the following tasks will close this issue.

- Perform an LFCM test of about 20-days duration in FY 1991 for the following activities.

- Provide preliminary throughput confirmation for the modified DWPF melter design to be used in HWVP with NCAW simulated feed.

- Evaluate cadmium, lead, tellurium, selenfum, tin, antimony, and todine volatility and establish offgas system decontamtnation factors for all feed components.

- Perform detalled mass balance with error analyses to provide data for confirmation of the WFQ MBM.

- Incorporate zeolite and diatomaceous earth from TRU recycle into the feed stream.

- Integrate melter and offgas performance with the full-scale feed preparation system, including the melter feed pump loop and slurry sampling system.

- Test the DWPF glass sampler for remote operablitty and use sampling data for process evaluation and control.

- Assess melter performance using differential pressure glass pouring with the prototypic HWVP offgas system. 
- Charactertze submerged bed scrubber (SBS) operation following design modifications.

- Assess impact of plenum heaters on through-put rate.

- Conduct an IDMS test in FY 1991 to obtain design information and evaluate the behavior of specific feed components (urantum, high. chloride, mercury, etc.) as required. The need, spectflc objectives, and length of this test will be established in early FY 1991 vitriftcation testing planning.

- Perform LFCM tests for a total of 40 to 60 days in FY 1992 for the following activities.

- Confirm/verify the TOC oxidant model to be used in the feed specification.

- Evaluate the effects of melter normal feeding and overfeeding on melter cold cap behavior and offgas system surge performance.

- Continue assessing the impact of zeollte and dlatomaceous earth on feed through-put rate.

- Evaluate the offgas system dynamic response versus vartable atr flow and feed concentration conditions, including offgas system upset temperature and pressure.

- Determine the effectiveness of SBS solids cleanout (sparge ring) design.

- Demonstrate long-term offgas system performance.

- Determine high-efficlency mist eliminator (HEME) loading rates and washdown requirements. Evaluate the degradation of the HEME and high-effictency particulate air (HEPA) fliter media caused by exposure to MOG and project service iffe.

- Determine operational characteristics of the MOG fllin cooler reamer.

- Determine the extent of MOG line plugging potential.

- Verify flowsheet and equipment operation with TRU waste recycle.

- Evaluate improved melter instrumentation materials.

- Test the compositional shift from NCAW to NCRW and observe glass composition and redox response.

- Obtain mass balance and PCCS model input data for WFQ evaluation. 
- Fll1 full-scale cantsters for welder evaluation, drop testing, and cantstered product evaluation.

- Perform LFCM testing in FY 1993 to provide data for WFQ mass balance, PCCS, and durabllity models and evaluation of NCRW, CC, and PFP feed(s) including processing of high- and low-viscosity glasses.

- Perform 1/10. scale me'lter tests in FYs 1992 through 1995 for the following activity.

- Evaluate melter performance charactertstics and feed glass processibllity at the operating limtts of the glas QCR prtor to pllot-scale melter runs.

- Perform plant prototypic melter (1/3- or 1/2-scale) tests in FYs 1994 through 1999 to accomplish the following objectives.

- Confirm HWVP melter design, including more rellable or replaceable pour spout heaters, replaceable thermocouples, and melter through-put capability.

- Process simulant NCAW, NCRW, CC, and PFP feeds at nominal and limit conditions in fulfillment of process qualification testing requirements.

- Demonstrate use of the differential pressure glass pouring system with the HWVP prototyplc offgas system.

- F111 full-scale canisters for WFQ glass product model verification.

- Confirm destgn of cantster glass-level-detection system

- Provide WFQ data and pre-validate the WFQ MBM for coding in the HWVP DCS.

- Confirm offgas system DFs and provide melter losses during Idling to support WFQ model work.

- Obtain verification of long-term vitrification system performance capability.

- Provide input to the HWVP qualification run cold-test matrix.

- Confirm the capability and rellablltty of the DCS to remotely control the process using avallable instrumentation and established process parameter ranges.

- Demonstrate capabilittes of the PCCS for evaluation of processing options and predicting glass composition. 


\subsubsection{Schedule Requitremonts}

Melter testing to support detalled design of process equipment must be completed by September 1992. Other tests will be ongoing through Fy 1999. The milestones listed in Table 4-4 were established for closure of this tssue (see Summary Schedule, Figure 11-1, in Section 11.0).

\section{3 .6 Costs}

The following cost breakdown was established for this issue (expense dollars in thousands):

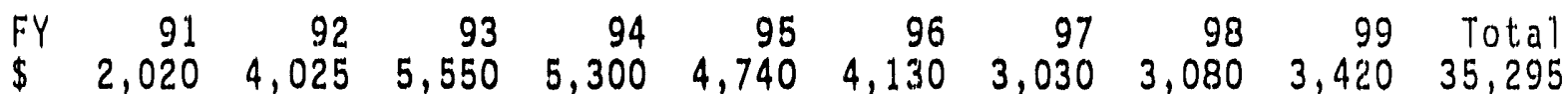

Funding requirements are based on prevtous costs for PSCM testing with approprlate adjustments for the scope of work to be accomplished in each test. The FY 1991 cost includes an IDMS test for approximately $\$ 1,000,000$ that requires further negotiation with SRS and DOE-RL management.

\subsection{MELTER OFFGAS SYSTEM}

The HWVP melter will generate an offgas stream consisting of steam, inleakage and film cooler alr, decomposition gases, volatlle or semivolatile compounds and elements, and entratned particulate matter that requires treatment. The MOG treatment system will remove radtoact tve particulates and noxious gases to meet HWVP emission 11 mits. Technology will be developed and/or verffled where necessary to ensure the reference HWVP MOG treatment system can meet established performance requirements for the health and safety of the public and the plant personnel.

\subsubsection{Melter Offgas System Performance Evaluation}

(WBS: 1.2 .2 .03 .05 )

4.4.1.1 statement of Issue. The pirformance charactertstics of the HWVP MOG treatment system need to be establlshed during a wide range of process conditions. The use of an SBS for the HWVP design was assessed cluring the PSCM run in FY 1988, and the test data veriffed that the large-scile equlpment to be used in the HWVP MOG system will perform according to design expectations. Established DFs, based on test data, need to be acquired for the DWPF melter using a WVDP offgas treatment system during many years to obtain a database that demonstrates environmental compliance. In addition, some hazardous elements in the HWVP reference feed range need further performance and flowsheet evaluation. 
WHC - EP-0350

Table 4-4. Vitriffcation Milestone List. (sheet 1 of 2)

\begin{tabular}{|c|c|c|}
\hline Milestone & $\begin{array}{c}\text { Completion } \\
\text { date } \\
\text { (quarter/FY) }\end{array}$ & Milestorie description \\
\hline 1 & $2 / 1991$ & $\begin{array}{l}\text { Issue test plans for LFCM and IDMS vitrift- } \\
\text { cation system testing to resolve destgn and } \\
\text { performance issues }\end{array}$ \\
\hline 2 & $4 / 1991$ & $\begin{array}{l}\text { Complete the 20-day LFCM run to provtde } \\
\text { melter through-put rate, feed component DFs, } \\
\text { glass sampler characteristics, and SBS } \\
\text { performance data }\end{array}$ \\
\hline 3 & $4 / 1991$ & $\begin{array}{l}\text { Complete IDMS test to resolve design issues } \\
\text { and provide information on spectfic HWVP } \\
\text { feed components (mercury, urantum, etc.) } \\
\text { that cannot be tested in the } 324 \text { Butlding }\end{array}$ \\
\hline 4 & $2 / 1992$ & $\begin{array}{l}\text { Issue vitrification system test report for } \\
\text { FY } 1991 \text { test }\end{array}$ \\
\hline 5 & $4 / 1992$ & $\begin{array}{l}\text { Complete a } 40 \text { - to } 60 \text {-day LFCM run to vertfy } \\
\text { meiter offgas system long-term performance } \\
\text { and compositton shift from NCAW to NCRW }\end{array}$ \\
\hline 6 & $4 / 1992$ & $\begin{array}{l}\text { Complete } 1 / 10 \text {-scale melter feed test to } \\
\text { support p } 1 \text { lot-scale melter performance } \\
\text { assessment at QCR itmits }\end{array}$ \\
\hline 7 & $4 / 1993$ & $\begin{array}{l}\text { Complete a } 20 \text { - to } 60 \text {-day LFCM run using } \\
\text { simulated } C C \text { and } P F P \text { feeds for WFQ model input }\end{array}$ \\
\hline 8 & $4 / 1994$ & $\begin{array}{l}\text { Complete a } 20 \text { - to } 60 \text {-day plant prototyptc } \\
\text { melter (1/3- or } 1 / 2 \text {-scale) run using } \\
\text { simulated nominal NCAW feed composition for } \\
\text { equipment design vertfication }\end{array}$ \\
\hline 9 & $4 / 1995$ & $\begin{array}{l}\text { Complete plant prototypic melter tests using } \\
\text { simulated feed to produce high- and low- } \\
\text { viscosity glasses within the QCR }\end{array}$ \\
\hline 10 & $4 / 1995$ & $\begin{array}{l}\text { Complete } 1 / 10 \text {-scale melter tests to evaluate } \\
\text { extremes of the QCR before conducting pilot- } \\
\text { scale melter tests }\end{array}$ \\
\hline 11 & $4 / 1996$ & $\begin{array}{l}\text { Complete plant prototyplc melter tests with } \\
\text { NCAW and NCRW feed simulants to provide data } \\
\text { for WFQ process model validation and HWVP } \\
\text { readiness review }\end{array}$ \\
\hline
\end{tabular}


WHC-EP.0350

Table 4-4. Vitriffcation Mtlestone List. (sheet 2 of 2)

\begin{tabular}{|c|c|c|}
\hline Mllestone & $\begin{array}{c}\text { Completion } \\
\text { date } \\
\text { (quarter/FY) }\end{array}$ & Milestone description \\
\hline 12 & $4 / 1997$ & $\begin{array}{l}\text { Complete plant prototyplc melter tests with } \\
\text { CC feed simulant to provide data for WFQ } \\
\text { process model valtdation and HWVP cold-run } \\
\text { test matrix }\end{array}$ \\
\hline 13 & $4 / 1998$ & $\begin{array}{l}\text { Complete plant prototyplc melter tests with } \\
\text { PFP feed simulant to provide data to support } \\
\text { HWVP qualification runs }\end{array}$ \\
\hline 14 & $4 / 1999$ & $\begin{array}{l}\text { Complete all required plant prototyptc } \\
\text { melter testing }\end{array}$ \\
\hline
\end{tabular}

DF $=$ Decontamination factor
IDMS $=$ Integrated DWPF melter system
PSCM $=$ Pllot-scale ceramic melter
QCR $=$ Qualified composition region

A new SBS was constructed in FY 1990 for use with the LFCM. The SBS uses Intalox* saddles as the bed media, an improved gas distribution plate, a solids flutdization system to enable removal of accumulated solids from the SBS bottom, and a sloped floor to improve collection of sollds in a speciffc location. Numerous SBS design issues shown in Table 1-2 must be resolved as early as possible in FY 1991 to maintain the Detailed Destgn schedule.

A new film cooler was constructed in FY 1990 for operation with the LFCM. The film cooler incorporates desicy features to minimize butidup of solids in the inlet. Long-term testing if the film cooler, in conjunction with the film-cooler reamer, is needed tis verify design performance with HWVP feeds.

4.4.1.2 Scope. The MOG treatment system evaluation will be conducted concurrent with scheduled melter runs in FYs 1991 through 1999. New equipment required for LFCM testing includes the following thems: a newly designed SBS, an offgas 1 ine and $111 \mathrm{~m}$ cooler, a film-cooler reamer, a roughing filter, a dual HEPA filter bank with assoctated heater, and a system blower. Spectaitzed tests will be performed to provide information for regulatory compliance and system performance evaluation. This task also includes evaluation of the plant prototypic MOG system scheduled to begin operation in FY 1994 and to continue to FY 1999.

4.4.1.3 Status. The HWVP reference offgas system with currently planned full

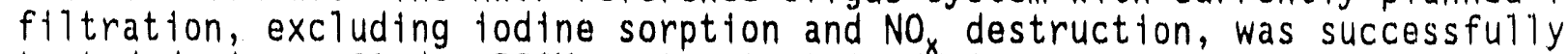
tested during a 20-day PSCM system test in FY 1988. Decontamination factors for all elements were established for regulatory permitting based on this test and other avatlable test data. It was determined from this test that

*Intālox is a irademark of Norton Company. 
offgas system monttoring downstream of the HEME should be improved for particulate detection before further MOG testing is inttiated. This work was completed in FY 1990. Testing of the new SBS, melter film cooler, and film cooler reamer is scheduled during LFCM runs in FYs 1991 and 1992.

4.4.1.4 Remainting Tasks. Completion of the following tasks will close thts issue.

- Add a new HEPA filter system and related heater to the LFCM offgas system (this upgrade of the extsting system is needed to handle the increased atr flow needed for LFCM operation).

- Perform offgas system testing in conjunction with melter runs using lid heaters and develop a database for feed component DFs.

- Evaluate the impact of hazardous chemical effluents on offigas system performance and on plant emisston limits. Hazardous chemicals to be evaluated are cadmlum, lead, I129, tellurtum, and selentum; however, other chemicals will be evaluated as required for the Final Safety Analysis Report (FSAR) (to be written).

- Perform component evaluation for the following activities.

- Obtain SBS pressure drop data needed for HWVP Detalled Destgn including the effects of steam flow (see Table 1-2).

- Establish long-term operating characteristics of the SBS and the HEME, including pressure drop across the SBS bed, $\mathrm{NO}_{x}$ removal, and HEME pressure drop and temperature.

- Evaluate the capability of the new LFCM film cooler destgn to inhibit solids accumulation in the inlet and measure pressure drop.

- Evaluatic performance characteristics of the new f1lm-cooler reamer.

- Evaluate the performance of the SBS design to improve particulate and soluble gas removal and the ablitty to remove solids accumulations from the bottom.

- Evaluate HEME and HEPA filter degradation.

4.4.1.5 Schedule Requirements. This issue will be resolved as the MOG system is evaluated in conjunction with melter runs during a pertod of many years and will support detafled design of process equipment, WFQ process modeling, HWVP regulatory compliance submittals, and HWVP startup and readiness review. The milestones listed in Table 4-5 were estabilshed for closure of this issue (see Summary Schedule, Figure 11-1, in Section 11.0). 
Table 4-5. Melter Offgas System Performance Evaluation Milestone List.

\begin{tabular}{|c|c|c|}
\hline Milestone & $\begin{array}{l}\text { Completion } \\
\text { date } \\
\text { (quarter/FY) }\end{array}$ & Milestone description \\
\hline 1 & $2 / 1991$ & $\begin{array}{l}\text { Issue test plan for SBS design and } \\
\text { performance eva? uation }\end{array}$ \\
\hline 2 & $3 / 1991$ & Provide SBS pressure drop data to Fluor \\
\hline 3 & $4 / 1991$ & $\begin{array}{l}\text { Complete preliminary testing of the offgas } \\
\text { system performance including film cooler and } \\
\text { reamer brush (pressure drop, plugging, DF, } \\
\text { etc.) for Detailed Design }\end{array}$ \\
\hline 4 & $2 / 1992$ & Issue offgas system performance report \\
\hline 5 & $4 / 1992$ & $\begin{array}{l}\text { Complete an evaluation of the film cooler } \\
\text { and reamer for Detailed Design }\end{array}$ \\
\hline 6 & $4 / 1992-4 / 1993$ & $\begin{array}{l}\text { Provide MOG sampling, analyze samples and } \\
\text { data, and describe testing results for the } \\
\text { LFCM melter runs }\end{array}$ \\
\hline 7 & $4 / 1994-4 / 1996$ & $\begin{array}{l}\text { Provide MOG sampling, analyze samples and } \\
\text { data, and describe testing results for the } \\
\text { plant prototypic melter runs }\end{array}$ \\
\hline 8 & $4 / 1997$ & $\begin{array}{l}\text { Provide confirmation of DFs to be used in } \\
\text { the FSAR }\end{array}$ \\
\hline 9 & $4 / 1998$ & $\begin{array}{l}\text { Complete an evaluation of the plant proto- } \\
\text { typic MOG system }\end{array}$ \\
\hline
\end{tabular}

FSAR = Final Safety Analysis Report

MOG = Melter offgas

4.4.1.6 Costs. The following cost breakdown was established for this issue (expense dollars in thousands):

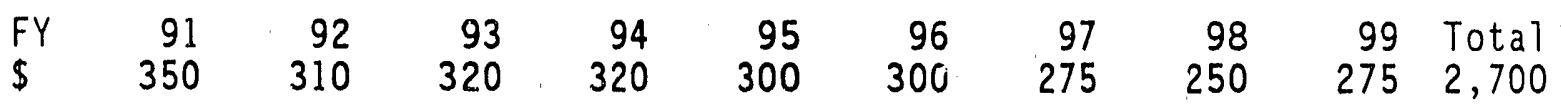

The above funding levels are based on estimates of staff time and other. costs required to accomplish the scope of work. The FY 1991 costs include special testing to obtain data needed to close specific Detailed Design issues. 
WHC-EP-0350

\subsection{WASTE TREATMENT (WBS: 1.2 .2 .03 .06 )}

\subsubsection{Statement of Issue}

In FY 1989, Fluor recommended a design approach for waste treatment in the HWVP using zeolite for batch contacting and sorption of cesium and strontium. The radionuclide-loaded zeolite and TRU waste solids are filtered from the process waste slurry. The filtrate is routed to the HWVP hold tanks for subsequent transfer to Tank Farms. The zeolite, with the sorbed cesium and strontium together with the TRU solids, will be included with the HWVP feed for vitrification.

For HWVP application, Fluor recommended that zeolite (Linde Ionsiv IE-96)* be added directly to a process tank for batch contacting to simplify the process and equipment. Fluor recommended using zeolite crystals that have a particle size of 10 to $15 \mu \mathrm{m}$ for the HWVP TRU recycle system because these fine crystals may be suitable for body feed during filtration. Zeolite use with batch contacting versus a column will result in higher zeolite utilization for an equivalent cesium recovery. Studies are needed to determine if the IE-96 zeolite crystals are sufficient for removal of strontium and actinides with $\mathrm{pH}$ adjustment. The relationship between $\mathrm{pH}$ and zeolite sorption needs to be established for a wide range of processing conditions so a control methodology can be implemented. More work is also needed to verify that TRU waste solids filtration from high-pH solutions will be adequate to remove the needed TRU content from the waste. Testing indicates use of diatomaceous earth as a filter precoat material, and possibly as a body feed, will be required for filtration. This material will be processed into glass by transfer to an intermediate vessel and routed to the SME. Work is in progress to determine if the 10- to $15-\mu \mathrm{m}$ zeolite crystals are acceptable as body feed, thereby eliminating the need to add additional diatomaceous earth to the batch contact vessel prior to filtration. The batch-to-batch impact of zeolite and diatomaceous earth additions on glass formulation and canister productions also needs further assessment.

Pilot-scale prototypic filter testing was conducted using a $\mathrm{Fe}(\mathrm{OH})_{3}$ based simulant slurry to verify operating characteristics and design calculations. Demonstration of the ion-exchange and filtration system in conjunction with melter runs is needed to assess processing characteristics and melter through-put for HWVP design and process verification. Testing should include evaluation of zeolite and filter process performance using a more representative synthetic waste and a larger scale filter. Verification testing of the plant prototypic melter through-put with additions of recycled waste is also needed.

*Linde Ionsiv IE-96 is a trademark of Union Carbide Corporation, Linde Division, New York, New York. 


\subsubsection{Scope}

The scope of this task includes pilot-scale filtration testing of the TRU waste treatment process and subsequent verification of the processing rate of this stream in a melter. In addition, the impact on WFQ needs will be evaluated including accountability for the recycled products and an assessment of the impact on the WFQ model including analytical and mass flow uncertainties.

The following activities are also included in the scope of this task.

- Assess impact on melter through-put rate of zeolite and diatomaceous earth additions to synthetic NCAW feed prepared for LFCM runs.

- Conduct laboratory-scale tests to determine pH control for zeolite sorption.

- Conduct pilot-scale testing of the ion-exchange, batch-contact process in conjunction with the full-scale feed preparation test equipment and the plant prototypic melter.

- Conduct laboratory- and pilot-scale testing of a prototypic filter to evaluate in-cell precoating and equipment performance.

\subsubsection{Status}

Zeolite was developed and used extensively to remove cesium from radioactive waste solutions in the following applications:

- Hanford Site B Plant waste management, isotopes recovery, and cesium purification (encapsulation)

- Three-Mile Island Unit II cleanup

- WVDP.

Technology was developed for incorporation of zeoltte into glass from the following tests.

- The WVDP vitrification development was conducted in the PSCM tests using zeolite resin in the feed.

- The DWPF vitrification development in the PSCM tested zeolite resin in melter feed.

- The full-scale tests at WVDP have used zeolite resin containing a clay binder in the melter feed.

In general, these tests revealed that feed containing zeolite processes satisfactorily and produces an acceptable glass form. Some additional work was performed at WVDP to address zeolite size reduction and scum formation. 
The WVDP plans to grind the zeoltte to a smaller size to facilttate obtaining representative vitrification waste feed samples. Also, IE-96 zeolite was selected over IE-95 at WVDP to reduce the potential for calcium cementation of the IX column.

Work for HWVP was completed in FY 1990 to accomplish the following objectives.

- Zeolite/liquid distribution coefficients and sorption rates on candidate zeolites as a function of sodium concentration, temperature, solution $\mathrm{pH}$, and contact time were determined for commercial-use particle-size zeolites IE-96, IE-95, and A50. Sorption data were provided for strontium, cesium, and actinides. The zeolite IE-96 selected by Fluor for process application was found to have adequate sorption characteristics for cestum. The strontium sorption characteristics were lower than anticipated. The solubility of plutonium was low enough that it could be adequately removed by filtration from high-pH solutions.

- The stability of zeolite under attack by fluorides, chlorides, and radiation was assessed and found to be adequate for the batch operation.

- Actinide removal efficiencies by filtration under processing conditions were determined to be adequate due to low solubility in neutral and alkaline solutions.

- The reaction rate equations and mass transfer coefficients used for design by fluor for the selected zeulite for in-tank batch contacting using smaller mesh sizes were found to be acceptable.

- Flowsheet studies determined that changes in glass composition and the effects on the acceptable glass composition processing envelope due to zeolite, filter aid, sodium introduction for $\mathrm{pH}$ adjustment, and TRU solids recycle were significant but manageable.

- Short-term loading efficiency test.s were conducted on laboratoryand pilot-scale precoat filters to verify operation at HWVP processing conditions. The tests demonstrated that the filter selection was appropriate for design by removing greater than 99 percent of the synthetic SBS solids [based on use of $\mathrm{Fe}(\mathrm{OH})_{3}$ for testing] and the design amount of solids per cycle using precoat and body feed could be loaded on the filter.

- The impact of recycle streams on the WFQ process model, including sampling, analytical, and process mass flow uncertainties, and on product certification, was included and analyzed. There was no significant impact.

- The need for a process grinding step was assessed. It was determined that use of the zeolite crystal without binder ( $\leq 50 \mu \mathrm{m}$ in diameter) will eliminate the need for grinding. 
- Testing showed that the commercial size (approximately $50 \mu \mathrm{m}$ ) zeolite crystals were not acceptable as a replacement for the diatomaceous earth body feed.

Studies conducted by PNL in FYs 1989 and 1990 indicate the powdered zeolite-ion exchange media, Linde Ionsiv IE-96, will be acceptable for HWVP operation based on the Fluor flowsheet. Further testing is needed to evaluate IE-96 performance for all waste treatment applications within HWVP.

\subsubsection{Remaining Tasks}

Completion of the following tasks will close this issue.

- Conduct laboratory - and pilot-scale batch contact of zeolite with simulant SBS solutions containing strontium and cesium to determine large-scale reaction kinetics, distribution ratios as influenced by equipment operation, and method for $\mathrm{pH}$ control of zeolite sorption.

- Evaluate the analytical and sampling uncertainty of samples taken from the recycle waste collection tank (RWCT) that will contain a mixture of glass frit from canister decontamination, TRU solids, diatomaceous earth, and zeolite. The full-scale feed preparation system and sampler described in Section 4.2.2 will be used for this evaluation.

- Evaluate the impact of maximum content of zeolite and diatomaceous earth on the melter feed processing rate during melter runs described in Serition 4.3.

- Conduct a pllot-scale test of the Fluor-recommended filter in conjunction with the full-scale melter feed preparation tests during LFCM and plant prototypic melter vitrification testing.

\subsubsection{Schedule Requi,-iements}

Verification testing of a pilot-scale ion-exchange batch-contacting and filter system will be completed in FY 1992 to validate Definitive Design and operational characteristics. Further vitrification testing will be conducted in subsequent years to complete a TRU recycle system evaluation. The milestones 1isted in Table 4-6 were established for closure of this issue (see Summary Schedule, Figure 11-1, in Section 11.0).

\section{5 .6 Costs}

The following cost breakdown was established for this issue (expense dollars in thousands):

$\begin{array}{lrrrrrrrrrr}\text { FY } & 91 & 92 & 93 & 94 & 95 & 96 & 97 & 98 & 99 & \text { Total } \\ \$ & 150 & 480 & 150 & 200 & -- & -- & -- & - & -- & 980\end{array}$


WHC-EP-0350

Table 4-6. Waste Treatment Milestone List.

\begin{tabular}{|c|c|c|}
\hline Milestone & $\begin{array}{l}\text { Completion } \\
\text { date } \\
\text { (quarter/FY) }\end{array}$ & Milestone description \\
\hline 1 & $2 / 1991$ & $\begin{array}{l}\text { Issue report describing results of zeolite } \\
\text { body feed tests }\end{array}$ \\
\hline 2 & $2 / 1991$ & $\begin{array}{l}\text { Issue a test plan for laboratory- and pllot- } \\
\text { scale testing to resolve Detailed Design } \\
\text { issues }\end{array}$ \\
\hline 3 & $4 / 1991$ & $\begin{array}{l}\text { Issue a report describing results of testing } \\
\text { to resolve Detailed Design issues }\end{array}$ \\
\hline 4 & $4 / 1992$ & $\begin{array}{l}\text { Complete installation of waste treatment } \\
\text { system for operation with full-scale feed } \\
\text { preparation }\end{array}$ \\
\hline 5 & $4 / 1993$ & $\begin{array}{l}\text { Complete testing to determine sampling and } \\
\text { analytical uncertainty associated with } \\
\text { transuranic recycle and verify filter } \\
\text { operation for Detailed Design }\end{array}$ \\
\hline 6 & $4 / 1994$ & $\begin{array}{l}\text { Complete an operational evaluation of } \\
\text { transuranic recycle system to provide data } \\
\text { for prototypic melter runs }\end{array}$ \\
\hline 7 & $4 / 1995$ & $\begin{array}{l}\text { Complete an evaluation of the feed processing } \\
\text { rate with transuranic recycle using the plant } \\
\text { prototypic melter to provide data for WFQ } \\
\text { process models and HWVP readiness review }\end{array}$ \\
\hline
\end{tabular}

These estimated costs were prepared from actual costs for earlier TRU recycle testing and a preliminary cost breakdown for equipment to be procured and installed in FY 1992.

\subsection{HANFORD WASTE VITRIFICATION PLANT APPLIED TECHNOLOGY HANDBOOK (WBS: 1.2 .2 .03 .07 )}

\subsubsection{Statement of Issue}

Technology summary information is needed to provide the technical bases for HWVP design/specifications; to inform HWVP engineering, design, and operations staff of technical information availability; to provide a link in the traceability of technical information; and to train HWVP staff on HWVP process technology. To provide the required data for the Hanford Waste Vitrification Plant Applied Technology Handbook, process technology information developed during each FY for HWVP must be evaluated for applicable techinica? content and incorporated as appropriate. 


\subsubsection{Scope}

The scope of this effort is to periodically summarize and reference HWVP process technology developed by PNL and other domestic/foreign sites as source material for HWVP design/specifications/operation appitications. Sufficient context will be provided with the technical information to enable the Handbook user to accurately apply the information for the intended use and to orient HWVP technical staff on the technology status of the HWVP. This task will cover activities through FY 1994 when the HWVP Project, wi11 initiate work on the Hanford Waste Vitrification Plant Technical Manual. At that time, funding for this activity will be provided elsewhere.

\subsubsection{Status}

An HWVP Applied Technology Handbook, titled Technology Manual, was initially compiled. This Manual was divided into nine major sections by plant technology areas. Technical format and content have evolved based on the available information and Project requirements. Plans are to update the technology sections that contain information on waste form development, feed receipt, feed preparation, melter feed, melter/turntable, MOG treatment, waste handling and treatment, and equipment construction materials.

\subsubsection{Remaining Tasks}

Periodically, the Handbook will be partially updated to incorporate the current applicable technical information developed for the HWVP or at other sites. An annual update is planned beginning in FY 1992 due to the quantity of information to be evaluated and summarized.

\subsubsection{Schedule Requirements}

The activities associated with updating the Hanford Waste Vitrification Plant Applied Technology Handbook must be completed by FY 1994. The milestones listed in Table 4-7 were established for closure of this issue (see Summary Schedule, Figure 11-1, in Section 11.0).

\subsubsection{Costs}

The following cost breakdown was established for this issue (expense dollars in thousands):

$\begin{array}{lrrrrrrrrrr}\text { FY } & 91 & 92 & 93 & 94 & 95 & 96 & 97 & 98 & 99 & \text { Total } \\ \$ & 30 & 125 & 180 & 190 & 80 * & 80 * & 75 & \ldots * & \ldots * & 760\end{array}$

The above costs are estimates of the staff time required to update the various sections of the HWVP Applied Technology. Handbook. The estimates are based on costs incurred for section updates in FYs 1989 and 1990.

*Additional funding is anticipated from an HWVP task to prepare a Technical Manual under another WBS during these years. 
Table 4-7. Hanford Waste Vitriftcation Plant Applled Technology Handbook Milestone List.

\begin{tabular}{|c|c|c|}
\hline Milestone & $\begin{array}{l}\text { Completion } \\
\text { date } \\
\text { (quarter/FY) }\end{array}$ & Milestone description \\
\hline 1 & $3 / 1991$ & $\begin{array}{l}\text { Complete modiffcations of HWVP Applied } \\
\text { Technology Handbook sections inttiated in } \\
\text { FY } 1990\end{array}$ \\
\hline 2 & $4 / 1992$ & $\begin{array}{l}\text { Complete update of the HWVP Applied } \\
\text { Technology handbook for. HWVP Definittve } \\
\text { Design }\end{array}$ \\
\hline 3 & $4 / 1994$ & $\begin{array}{l}\text { Complete update of the Appl ted Technology } \\
\text { handbook for input to the HWVP Technical } \\
\text { Manual. }\end{array}$ \\
\hline
\end{tabular}

$$
4-33 / 4 \cdot 34
$$




\subsection{EQUI PMENT ADAPTATION - PACIFIC NORTHWEST LABORATORY (WBS: 1.2 .2 .04 .00$)$}

The issues in this section address DWPF, WVDP, and Hanford Site (primarlly PNL) equipment technology adaptation to the HWVP. The issues inclide an evaluation of specific HWVP requirements as they affect equipinent design and performance. Reltablltty, malntalnabllity, and cost effectiveness of HWVP process equipment are sought through resolution of the described issues.

The following funding was allocated for planning and coordination of the PNL equipment adaptation and testing activities (expense dollars in thous ands):

$\begin{array}{lrrrrrrrrrr}\text { FY } & 91 & 92 & 93 & 94 & 95 & 96 & 97 & 98 & 99 & \text { Total } \\ \$ & 100 & 120 & 85 & 50 & \ldots & \ldots & \ldots & \ldots & \ldots & 355\end{array}$

The costs for each fiscal year are based on actual costs to accomplish work in prevtous years.

\subsection{MELTER/TURRTABLE SYSTEM}

This section reflects the overall plan to assess. HWV melter performance for processing feed containing noble metals and to provtde a plant prototyplc glass melter for HWVP verification testing. The plant prototyptc melter will be used to generate data needed for HWVP qualification runs and assess pour. spout heater improvements being designed trito the HWVP reference melter. Testing of the HWVP plant prototyptc melter is described in Section 4.3. Another task described in this sectlon deals with decommissioning of the melter because several melters are expected to be needed to complete processing of the HWVP feeds. Extension of the HWVP misston to include single-shell tank waste would require additional melters.

\subsubsection{Melter Performance Assessment (WBS: 1.2.2.04.01)}

5.1.1.1 Statement of Issue. The DWPF melter was selected for the HWVP reference melter design in 1990. There is concern that noble metals could precipitate during vitrification of pretreated NCAW feed resulting in reduced melter 1 ife through electrical shorting. Efforts are in progress to determine the amount of noble metals in NCAW. Studies were initiated in FY 1990 to evaluate noble metals chemical and thermal behavior during processing. Testing and melter modeling are needed to determine the impact of noble metals precipitation on the HWVP melter performance and Iffe expectancy. Use of minor design enhancements, such as bubblers or ratsing the melter lower electrodes several centimeters (inches) from the bottom, has been suggested as having potential in prolonging melter life and should be evaluated.

Modiftcation of the HWVP melter to incorporate a replaceable or more reltable pour-spout heater design and replaceable thermocouples to improve melter iffe has been approved and destgn changes will be immedtately inttiated 
by Fluor using existing technology. Implementation of this melter modiftcation is a destgn issue that is being closely followed. The FRG ceramic block resistance heaters are under consideration.

The bottom drain on the DWPF melter was not intended for normal cantster flliting and is only expected to operate a few times for final draining of the melter. The use of a bottom dratn in a melter with steeply sloped stdes for routine canister filling has been shown by the FRG to be benefictal in preventing the accumulation of precipltated siudges. Development of an improved reusable bottom drain for routine glass pouring or removing a preclpitated phase from the HWVP $45 . \mathrm{kg} / \mathrm{h}(100-1 \mathrm{~b} / \mathrm{h})$ reference melter was inttlated in FY 1989. This design was based on Japanese and FRG melter testing and experiences. Use of an improved bottom drain for periodic draining of the melter to remove sludge and shift the melter composition for the $100-\mathrm{kg} / \mathrm{h}(220-1 \mathrm{~b} / \mathrm{h})$ DWPF destgn melter should be reviewed as an alternative for prolonglng the melter Iffe. An improved bottom drain concept has been proposed for the DWPF melter and subsequent efforts in this area w111 require collaboration between HWVP and DWPF staff.

5.1.1.2 Scope. To resolve noble metal issues assoctated with the HWVP melter, the following scope of activities is planned.

- Evaluate analytical methods for determining noble metals in waste slurries and glasses. Select methods to be used for analys is of samples to be taken from laboratory- and pllot-scale melter tests descrtbed below.

- Evaluate simulant preparation to determine impacts of different methods for noble metal acid solution addition to the feed slurry and to select method for stmulant feed preparation.

- Conduct laboratory-scale gradient furnace tests to determine the cold cap chemical reaction products and alloying behavior for the noble metals in an NCAW slurry and assess the impact on test(s) to be conducted in an ESM.

- Coriduct research-scale melter run using NCAW feed containting noble metals to support ESM run.

- Conduct an ESM run using NCAW simulant feed containing noble metals to evaluate noble metals precipitation and accumulation in the melter. Evaluate minor design enhancements to improve melter performance.

- Provide melter modeling support to evaluate melter performance and 11 ffe expectancy of the HWVP melter for processing NCAW feed.

- Conduct tests using an improved melter bottom drain that can be used for periodic removal of siudge from the melier.

- Provide an assessment of HWVP melter 1 ife for processing NCAW and recommendations for minor design enhancements of the melter.

5.1.1.3 status. In early FY 1990, a melter development action plan was developed to obtain data required to assess the performance of the HWV melter 
WHC-EP- 0350

for processing feed containing noble metals. Avallable data from PNL, FRG, and SRS were obtalned and analyzed to evaluate the status of technology and to plan subsequent testing activities. Arrangements were made for HWVP staff to particlpate in noble metal melter runs at KfK in the FRG and at SRS in order to obtaln additional information. In addition, efforts are being made to perform chemical analyses on radtoactive NCAW core samples to determine the noble metals concentration in this Hanford waste lype.

A varlety of bottom dratns for melters has been destgned and tested by the Japanese, FRG, and DWPF. Operational and maintenance difficulttes have been observed including rapid corrosion, electrical shorting, and flow control difficulties. Additional work has been performed by the developers to resolve specific issues that would be used as input for the HWVP melter drain destan.

Efforts are in progress to negotiate a PNL contract with KfK for a collaborative melter run (1/10-HWVP scale) in the FRG at the KfK faclltties. If contract negotlations are successful, KfK staff will design an ESM Using the FRG ceramic resistance-heated block pour-spout heaters and the FRG induction-heated bottom drain. Labor costs for melter and feed system destun, installation, operation, analytical support, and reporting will be provided by KfK. The HWVP Project will pay costs for the melter and feed system construction, feed preparation including noble mietals, and a fee for services to run the melter.

The PNL has inftlated work to support an ESM run, including gradlent furnace testing of HWVP, KfK, and SRS feeds to evaluate phase behavior, evaluation of analytical methods for noble metals, computer modeling for melter $1 \mathrm{ffe}$ assessment, and research-scale melter (mint-melter) runs using HWVP feed simulant containing noble metals. This work will be continued in FY 1991: on a schedule that provides supporting data for the ESM run in the FRG.

5.1.1.4 Remaining Tasks. Completion of the following tasks will close this tssue,

- Evaluate analytical results on radioactive waste tank core samples to determine the appropriate concentrations of noble metals to be used in synthetic waste for vitrification testing.

- Evaluate noble metal feed preparation techniques and perform gradient furnace and research-scale melter tests to determine characteristics of noble metal phases that form in HWVP glass.

- Investigate analytical procedures to tmprove noble metals quantitative analytical methods.

- Perform an ESM (approximately 1/10-scale) run at KfK with HWVP feed containing noble metals to characterize the behavior of noble metals in a melter of HWVP geometry.

- Test approaches to maintain the noble metals in suspension or in a llutd state for drainting (1.e., bubblers and/or power skewing). 
WHC - EP. 0350

- Perform melter mathematical modeling to project results from small. scale melter testing to production-size melters for predicting behavior of noble metals and the operatirig character-istics of the HWVP melter for processing NCAW.

- Assess avallable information from the SRS, FRG, Japan, and PNL to make recommendations on the HWVP meiter destgn to accommodate noble metals.

- Test alternate designs for the pour-spout heaters and bottom drain for use on a $100-\mathrm{kg} / \mathrm{h}(220-1 \mathrm{~b} / \mathrm{h})$ glass melter based on designs avallable from the FRG.

5.1.1.5 Schedule Requirements. All tasks in this issue must be closed by the end of FY 1993 to support the design of the second HWVP melter. The milestones 1tsted in Table 5-1 were established for closure of this issue (see Summary Schedule, Figure 11-1, in Section 11.0).

5.1.1.6 Costs. The following cost breakdown was established for this issue (expense dollars in thousands):

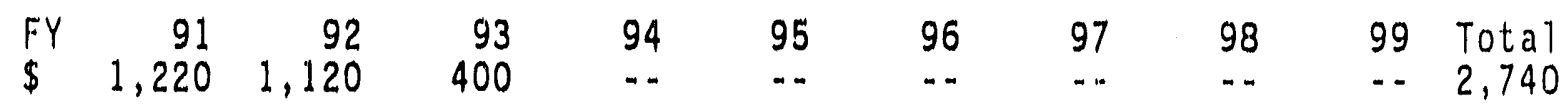

Estimated costs for work to be conducted in FY 1990 aro based on cost breakdowns for varlous studies to be performed by PNL and a formal offer for the ESM work being prepared by KfK. Funding requirements projected for FYs 1992 to 1993 are based on continuation of the KfK work to assess melter chancements assuming costs will not change apprectably from the detafled $k$ ix offer.

\subsubsection{Plant Prototyplc Glass Melter (WBS: 1.2 .2 .04 .02 )}

5.1.2.1 Statement of Issue. Technology development planning was initlated in FY 1989 to obtain a testing capability consisting of a plant prototyplc glass melter in conjunction with a full-scale feed preparation system to provide integrated test data for WFQ, HWVP readiness revlew, and HWVP process qualification cold testing. Overall planning is based on having a plant prototyplc glass melter avallable for testing of feeds by FY 1994. No dectsion has been made on the size of the melter but at least $1 / 3$ - or $1 / 2$-scale would probably be needed to show relevancy to the HWVP melter operation. Design improvements would include more reliable or replaceable pour-spout heaters and replaceable thermocouples. The melter would have other simflar features and geometry as the HWVP reference melter $(1, \theta .$, the DWPF melter design).

The size of the melter system must be suffictent to obtain data for the WFQ mass balance and product models and to provide mixing characteristics close to those expected in the DWPF melter. The melter also must have a prototypic offgas system that can provide data for verification of DFs used for destgn. 
Table 5-1. Melter Performance Assessment Mtlestone List.

\begin{tabular}{|c|c|c|}
\hline Millestone & $\begin{array}{l}\text { Completion } \\
\text { date } \\
\text { (quarter/FY) }\end{array}$ & Mtlestone description \\
\hline 1 & $1 / 1991$ & $\begin{array}{l}\text { Issue a test plan for noble metal gradtent } \\
\text { furnace and mint-melter testing including } \\
\text { fead preparation }\end{array}$ \\
\hline 2 & $2 / 1991$ & $\begin{array}{l}\text { Issue test plan for research-scale melter } \\
\text { testing using feed containing noble metals }\end{array}$ \\
\hline 3 & $3 / 1991$ & $\begin{array}{l}\text { Complete gradient furnace and research-scale } \\
\text { melter studies to evaluate noble metals } \\
\text { behavior in HWVP glass }\end{array}$ \\
\hline 4 & $3 / 1991$ & Prepare and issue test plan for ESM test. \\
\hline 5 & $4 / 1991$ & $\begin{array}{l}\text { Complete evaluation of melter alternate } \\
\text { destgn pour-spout heaters, electrode } \\
\text { placement, and bottom drain and provide } \\
\text { recommendations for Detalled } \\
\text { Design }\end{array}$ \\
\hline 6 & $1 / 1992$ & $\begin{array}{l}\text { Conduct an ESM run using HWVP simulant feed } \\
\text { containing noble metals and provide } \\
\text { preliminary assessment of HWVP melter } \\
\text { performance }\end{array}$ \\
\hline 7 & $4 / 1992$ & $\begin{array}{l}\text { Issue HWVP melter performance assessment } \\
\text { report }\end{array}$ \\
\hline 8 & $4 / 1992$ & $\begin{array}{l}\text { Complete an evaluation of minor destign } \\
\text { enhancements for HWVP melter operation }\end{array}$ \\
\hline 9 & $4 / 1993$ & $\begin{array}{l}\text { Complete melter performance assessment } \\
\text { studies and provide recommendations for HWVP } \\
\text { melter design enhancements }\end{array}$ \\
\hline
\end{tabular}

[SM = Engineering-scale melter

Wavering of the glass stream as it leaves the discharge spout is an identiffed issue that may require further resolution. Information will be avatlable from DWPF startup, but operation characteristics may be somewhat different for HWVP because of the different destgn for the offgas system and pressure differential glass pouring. In any case, the plant prototypic melter will include a prototyplc discharge system for evaluation of this issue.

To accomplish these objectives, a plant prototypic glass melter with assoctated offgas and waste treatment systems wi11 need to be destgned, procured, and installed in the 324 Butlding High Bay and be avatlable for testing by the third quarter of FY 1994. 
5.1.2.2 Scope. The task to develop the plant prototyplc melter includes the following activities.

- Destgn, procure, and install the plant prototyplc melter and offoas and waste treatment systems.

- Design, procure, and install melter support equipment.

- Install the Distrfbuted Control System (DCS) for the melter and support equipment (addition to the existing control system for the full-scale feed preparation system).

- Acceptance-test the melter, offgas, and waste treatment systems.

- Add features to evaluate remote operation of the melter for canister fllling (gamma detectors and source).

- Provide for melter and support equipment startup.

5.1.2.3 Status. A full-scale feed preparation system with HWVP prototyptc sampling capabllity and melter feed pump loop will be installed in the 324 Bullding by about mid-FY 1991. This equipment will be acceptance-tested and operated with an LFCM run scheduled for FY 1991. The CENRTC funding for the plant prototypic glass melter has been identifled for FYs 1991 to 1993. Plans are to design, procure, and install the melter for technology studtes described earlier in Section 4.3 beginning in FY 1994.

5.1.2.4 Remaining Tasks. Completion of the following tasks wt11 close this issue.

- Prepare a comprehensive plan for design, procurement, and installation of the plant prototypic melter. This plan will include equipment and facility definition, a complete cost breakdown, and a schedule of al1 major activittes required to complete the work. The schedule and cost breakdown will be updated perfodically to track progress against the plan.

- Prepare prototypic melter, offgas, and waste treatment system designs, specifications, and documentation for procurements, factitty modifications, and installations.

- Procure, recetve, inspect, and install equipment for operation. provide safety and factlity readiness reviews as approprlate.

- Evaluate requirements for the melter, offgas system, and waste treatment equipment DCS. Upgrade the existing DCS being used for the full-scale SRAT/SME to provide controls for the melter, offgas, and waste treatment systems.

- Write procedures for melter operation with the full-scale feed preparation system and obtain approval for startup. Start up the melter and the offgas and waste treatment systems, and complete equipment acceptance testing. 
- Prepare test plan for plant prototypic melter testing.

- Provide features to evaluate remote melter operation (such as periscope viewing) and canister filling as required.

5.1.2.5 Schedule Requirements. The tasks associated with testing highviscosity feed and noble metals must be completed as early as possible to provide data for melter design verification and WFQ process model pre-

validation prior to HWVP cold runs. The milestones listed in Table 5-2 were established for closure of this issue (see Summary Schedule, Figure 11-1, in Section 11.0).

5.1.2.6 Costs. The following cost breakdown was established for this issue (dollars in thousands):

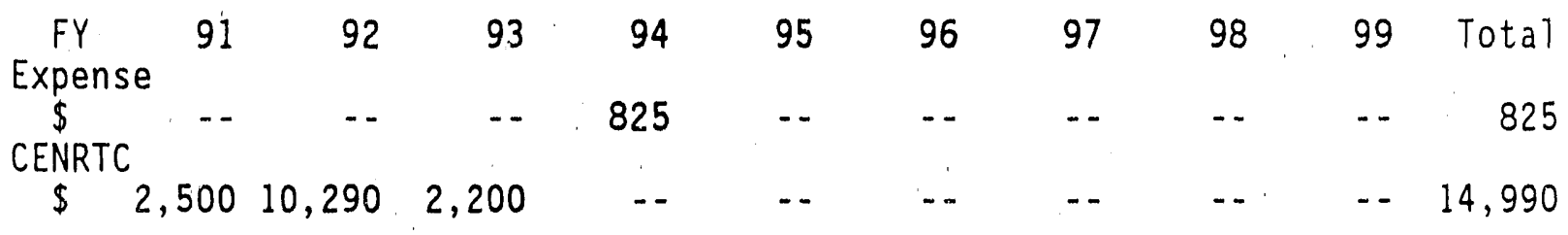

Table 5-2. Plant Prototypic Glass Melter Milestone List.

\begin{tabular}{|c|c|c|}
\hline Milestone & $\begin{array}{l}\text { Completion } \\
\text { date } \\
\text { (quarter/FY) }\end{array}$ & Milestone description \\
\hline 1 & $2 / 1991$ & $\begin{array}{l}\text { Provide a comprehensive plan for a plant } \\
\text { prototypic melter and support systems } \\
\text { design, procurement, and installation }\end{array}$ \\
\hline 2 & $4 / 1991$ & $\begin{array}{l}\text { Issue status report on plant prototypic } \\
\text { melter progress }\end{array}$ \\
\hline 3 & $4 / 1992$ & $\begin{array}{l}\text { Issue status report on plant prototypic } \\
\text { melter progress }\end{array}$ \\
\hline 4 & $4 / 1993$ & $\begin{array}{l}\text { Complete installation of a plant prototypic } \\
\text { melter and support systems }\end{array}$ \\
\hline 5 & $2 / 1394$ & $\begin{array}{l}\text { Complete the addition of features for remote } \\
\text { operation and canister filling on plant } \\
\text { prototypic melter for integrated testing } \\
\text { runs to provide data for WFQ ard HWVP } \\
\text { readiness review and cold runs }\end{array}$ \\
\hline 6 & $3 / 1994$ & $\begin{array}{l}\text { Issue test plan for plant prototypic melter } \\
\text { testing }\end{array}$ \\
\hline
\end{tabular}

Funding for this task is based on actual costs for a scale-glass melter procured by DWPF for melter testing. A detailed cost breakdown will be prepared in early FY 1991 to provide a firm basis for the cost estimate. 


\subsubsection{Melter Decummissioning (WBS: 1.2.2.04.03)}

5.1.3.1 Statement of Issue. The requitred design life of the HWV melter is 2 years; however, life expectancy could be more than double this time based on pilot-scale melter testing at the SRS. The melter wili require decummissioning for disposal at the end of its life consistent with Hanford Site capabilities for handling this large equipment. To facilitate decommis.sioning, further consideration must be given to the melter and facility design. Some verification of decommissioning steps, including evaluation and testing of remote tools, will also be needed. Although the melter should be drained before removal, all failure modes, including handling of a full melter, should be considered.

The FRG is planning to decommission the PAMELA melters at the beginning of 1992. Participation of PNL staff in the PAMELA melter remote disassembly is needed to obtain as much information as possible for the HWVP.

5.1.3.2 Scope. The HWVP facility and melter must be designed to allow decommissioning in the most expedient manner possible. Equipment must, be provided for the removal, disassembly (if roquired), packaging, shipment, and subsequent permanent disposal of the melter. Waste generated during melter disassembly must be segregated into TRU, low-, and high-level classifications. Recycle of the HLW to the HWVP vitrification process or other means of disposal must be evaluated. The scope of this task includes all aspects of melter decommissioning and waste disposal, i.e., selection of facilities, waste segregation, and waste disposal in HWVP.

5.1.3.3 Status. The DWPF melter weighs approximately 85 and 70 tons with and without the frame, respectively. A inethod for decommissioning the melter has not been developed. There has been no work on this task; however, a brief engineering evaluation was undertaken in FY 1989 to evaluate the alternatives for melter decommiss oning and disposal. This effort included consideration of the addition of a melter decommissioning cell in the HWVP.

\subsubsection{Remaining Tasks. Completion of the following tasks will close this} issue.

- Perform a melter decommissioning study. All steps in the removal and disposal of a failed melter must be considered, with particular attention paid to such items as impacts to the designs of the melter and facility, credible abnormal conditions, and disposal requirements. Recommendations will be documented in a report.

- Determine methods for handiing the melter components and provisions for disposal of each waste type. Provide requirements for melter decommissioning cell design and conceptual layouts for equipment as appropriate. Test and evaluate melter decommissioning techniques, as required, based on the outcome of the inelter deccmmissioning study.

- Participate ir PAMELA meiter decommissioning in the FRG.

5.1.3.5 Schedule Requirements. The milestones listed in Table 5-3 were established for closure of this issue. (see Summary Schedule, Figure 11-1, in Section 11.0). 
Table 5-3. Melter Decommissioning Milestone List.

\begin{tabular}{ccl}
\hline Milestone $\begin{array}{c}\text { Completion } \\
\text { date } \\
\text { (quarter/FY) }\end{array}$ & \multicolumn{1}{c}{ Milestone description } \\
\hline 1 & $4 / 1991$ & $\begin{array}{l}\text { Complete preliminary study to evaluate } \\
\text { alternatives for HWV melter decommissioning }\end{array}$ \\
2 & $4 / 1992$ & $\begin{array}{l}\text { Complete a melter decommissioning study } \\
\text { including testing of prototypic tools, to } \\
\text { provide data for detailed design }\end{array}$ \\
$4 / 1992$ & $\begin{array}{l}\text { Monitor PAMELA melter disassembly and } \\
\text { provide a recommendation for HWV melter } \\
\text { decommissioning } \\
4\end{array}$ & $\begin{array}{l}\text { Provide final melter decommissioning plans } \\
\text { and verify tool design including testing as } \\
\text { appropriate }\end{array}$ \\
\hline
\end{tabular}

5.1.3.6 costs. The following cost breakdown was established for this issue (expense dollars in thousands):

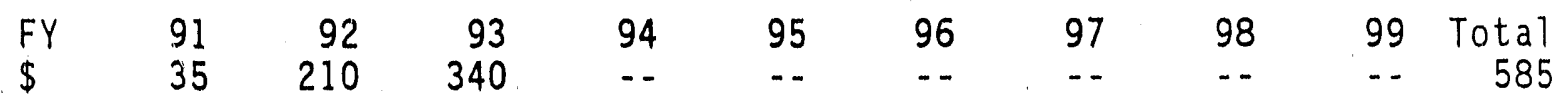

The estimated costs for this work are based on staff time to complete studies with additional support for fabrication of decommissioning tools if required for this evaluation.

\subsection{CANISTER CLOSURE, LEAK TIGHTNESS VERIFICATION, AND DECONTAMINATION}

Tasks described in this section cover various issues related to the canister closure method selected for the HWVP and methods used for decontamination. The process of GTAW was selected for HWVP in FY 1990 for cost-reduction reasons, and responsibility for this erjuipment was given to Fluor. Verification of the canister closure method for WFQ will be conducted to ensure WAS requirements are met.

These tasks provide methodology for closure of this issue assuming there will be further definition of requirements as efforts progress to obtain U.S. Department of Energy-Radioactive Waste (DOE-RW)/U.S. Nuclear Regulatory Commission (NRC) approval of the waste compliance plans for other sites.

The HWVP is using the DWPF slurry frit-blasting system for final canister decontamination. Consideration is being given, however, to adapting the $\mathrm{Ce}^{+4}$ canister decontamination system planned for use at WVDP, resulting in a cost savings. A preliminary decontamination station also has been 
planned in HWVP to remove loose contamination from the canister before moving the canister into the canister decontamination chamber (CDC). The preitiminary decontamination station is not being used by DWPF.

\subsubsection{Canister Closure and Weld Verification}

(WBS: 1.2 .2 .04 .04 )

5.2.1.1 Statement of Issue. The resistance upset welding canister closure method developed for the DWPF has been thoroughly tested but no weld verification techniques have been developed for the closure configuration. Acceptable equipment performance is justified by readings of the current, voltage, and other parameters used for closure. A method for sealing a canister that meets all NRC requirements must be developed and tested to provide a database for the HWVP WQR.

Fluor is conducting a study to select the canister welding method to be used for Detailed Design. If GTAW is selected by Fluor, prototypic equipment will need to be procured and demonstrated for the HWVP. Welding parameters that provide sufficient penetration to meet canister drop requirements and provide reliable fusion of the lid to the canister must be established. Procedures for weld rework are an essential part of this activity so that the acceptance can be as near as possible to 100 percent.

If the DWPF resistance upset welding process is selected by Fluor, a minimum amount of canister drop testing may still be required to obtain data for WFQ compliance. This task provides funding for transport of canisters to the SRS and completing final closure using existing plant welding equipment. This HWVP option will need to be negotiated with SRS management.

\subsubsection{Scope. The scope of this issue includes the following work.}

- Procure and install GTAW equipment for testing. Develop canister weld joint and lid configurations.

- Evaluate the impaciss of increasing the canister opening.

- Develop welding techniques and qualification methods for meeting WAPS including possible in-process sampling to verify equipment/operator performance.

- Develop a method for verifying the integrity of the weld and demonstrate remote operability.

- Weld a number of test canisters to provide an adequate database for WQR submittal and to provide canisters for drop testing.

5.2.1.3 Status. The means for compliance with the WAPS is under evaluation and this effort will provide further insight into steps that must be taken to resolve canister closure issues. No work has been initiated to obtain a welder for testing. 
Methods for examining the integrity of the weld will need to be developed as required. The only leak detection method planned to be used in HWVP is a pressure decay leak check on the canister inner closure plug. If helium leak checking is required to meet WAS requirements, this equipment would be installed in the canister shipping facility.

U1trasonic inspection devices were developed in the nuclear industry for inspection of fuel bundles and this type of measuring equipment could be placed in the canister inspection cell or tunnel where equipment will be contact-maintained. Some consideration of the weld joint may be needed to obtain the best possible configuration for inspection. There has been no work on this specific task; however, methods to evaluate canister welds by ultrasonic inspection and helfum leak check have been investigated by PNL. A technique was developed to inspect an inertia-welded canister using a vertically positioned transducer and a fine stream of water.

\subsubsection{Remaining Tasks. Completion of the following tasks will close this} issue.

- Maintain contact with Fluor on selection of the HWVP canister welder. If GTAW is selected, provide interface with Fluor staff for the design of the GTAW equipment and evaluation of a lid configuration.

- Assess impact of increasing the canister opening to reduce the potential for inadvertent glass buildup and blockage.

- Procure, insta11, and test an HWVP prototypic welder. Devise methods for providing process/operator qualification and in-process samples for equipment performance verification. Write draft procedures for welding, in-process sampling, and subsequent inspection of in-process samples to qualify the weld process.

- Develop a method for inspection of the cantster weld, if required. Verify the remote applicability of the selected method. Design and procure equipment for demonstration testing and for obtaining data for readiness review and the WQR. Write procedures for equipment operation and periodic testing to verify performance characteristics.

5.2.1.5 Schedule Requirements. The work associated with process assessmerit and equipment selection must be completed before completion of Definitive Design. Subsequent long-term testing will occur during several years to provide data for HWVP readiness review and the WQR. The milestones listed in Table 5-4 were established for closure of this issue (see Summary Schedule, Figure 11-1, in Section 11.0).

5.2.1.6 Costs. The following cost breakdown was established for this issue (dollars in thousands):

\begin{tabular}{|c|c|c|c|c|c|c|c|c|c|c|}
\hline $\begin{array}{c}F y \\
\text { Expense }\end{array}$ & 91 & 92 & 93 & 94 & 95 & 96 & 97 & 98 & 99 & Total \\
\hline $\begin{array}{c}\$ \\
\text { CENRTC }\end{array}$ & 150 & 275 & 175 & 80 & - & - & $\cdots$ & - & - & 680 \\
\hline$\$$ & 200 & - & - & -- & -. & - & - & $\ldots$ & - - & 200 \\
\hline
\end{tabular}


WHC -EP-0350

Table 5-4. Canister Closure and Weld Verification Milestone List.

\begin{tabular}{|c|c|c|}
\hline Milestone & $\begin{array}{c}\text { Completion } \\
\text { date } \\
\text { (quarter/FY) }\end{array}$ & Milestone description \\
\hline 1 & $4 / 1991$ & $\begin{array}{l}\text { Complete design and testing of the canister } \\
\text { closure configuration to be used for GTAW }\end{array}$ \\
\hline 2 & $4 / 1991$ & $\begin{array}{l}\text { Complete procurement and installation of a } \\
\text { prototypic canister welder as designed by } \\
\text { Fluor (assumes GTAW selection: }\end{array}$ \\
\hline 3 & $3 / 1992$ & $\begin{array}{l}\text { Issue test plan for GTAW qualification } \\
\text { testing }\end{array}$ \\
\hline 4 & $4 / 1992$ & $\begin{array}{l}\text { Conduct GTAW qualification testing and } \\
\text { provide welded canisters for leak check and } \\
\text { drop testing }\end{array}$ \\
\hline 5 & $4 / 1993$ & $\begin{array}{l}\text { Verify glass-filled canister welds using } \\
\text { plant prototypic equipment, if required }\end{array}$ \\
\hline 6 & $4 / 1994$ & $\begin{array}{l}\text { Complete canister closure and weld verifica- } \\
\text { tion testing for HWVP readiness review and } \\
\text { WFQ compliance plan submittal }\end{array}$ \\
\hline
\end{tabular}

These costs were estimated from staff time required to complete the work in each fiscal year and knowledge of equipment costs for the leak detector and pump-down chamber. A detailed cost breakdown for this work will be prepared in FY 1991. The estimated costs are based on the actual bid price for the WVDP welder and estimated staff time needed to support the remainder of the work.

\subsubsection{Canister Leak Check (WBS: 1.2.2.04.05)}

5.2.2.1 Statement of Issue. The shrink-fit closure plug mothod for sealing the canister before frit blasting decontamination will be laak-checked by a pressure decay technique to $2 \times 10^{-4} \mathrm{~atm}-\mathrm{cc} / \mathrm{s}$. This technique has been demonstrated by DWPF but further evaluation is needed to determine reproduc ability of the shrink-fit closure process and to verify that no difficulties in passing the leak check will arise during production.

A means for meeting the WAPS requirement of $10^{-7} \mathrm{~atm}-\mathrm{cc} / \mathrm{s}$ helium leak rate $\left(10^{-4} \mathrm{~atm}-\mathrm{cc} / \mathrm{s}\right.$ in most recent WAPS draft) for welded canisters needs to be demonstrated for the HWVP. Planning for this issue is based on meeting the leak tightness requirement as defined in the recent WAPS draft. Equipment for leak checking the GTAW closure method needs to be procured, installed, and used to obtain a database for HWVP readiness review and the WQR. Work will include writing procedures for equipment operation and periodic verifícatioun ố equitilitent perforimance. 
WHC-EP-0350

5.2.2.2 Scope. The scope of this issue includes the following activities.

- Evaluate avallable methods and equipment for measuring cantster leak tightness. Select a method that meets WAPS requirements.

- Procure, insta11, and test DWPF leak check equipment or other, as yet undefined, equipment.

- Leak check a number of canisters to provide a database for WFQ report submittal.

5.2.2.3 Status. There has been no work on this task. Efforts in progress to negotiate relaxation of requirements in the WAPS could impact this issue. In any case, equipment wil1 be needed to obtain experience with the selected method and provide data for the WQR. The PNL has developed and tested an approach for helium leak-checking canisters filled with radioactive glass for the FRG canisters. This approach has not been evaluated for appitcation to HWVP canisters.

5.2.2.4 Remaining Tasks. Completion of the following tasks will close this issue.

- Assess WFQ requirements for canister leak tightness. Determine the best available method for remote equipment operation and maintenance. Evaluate alternatives if the ANSI N14.5-1987 specification must be met.

- Procure, install, and test HWVP prototypic leak check equipment. Determine methods for providing process/operator qualification and periodic reinote testing of equipment performance. Write operating and testing procedures. Demonstrate equipment reliability.

- Obtain data to be used for readiness review and WFQ report submittal.

5.2.2.5 Schedule Requirements. Selection of leak rate measurement equipment to meet WAPS requirements must be resolved before completion of detailed design. Testing of this equipment will take several years to provide data needed to verify performance and operational capabilities. The milestones listed in Table 5-5 were established for closure of this issue (see Summary Schedule, Figure 11-1, in Section 11.0).

5.2.2.6 costs. The following cost breakdown was established for this issue (dollars in thousands):

\begin{tabular}{|c|c|c|c|c|c|c|c|c|c|c|}
\hline FY & 91 & 92 & 93 & 94 & 95 & 96 & 97 & 98 & 99 & Total \\
\hline Expense & 100 & 150 & 120 & 125 & - & 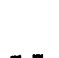 & $n$ & - & & $\Delta C$ \\
\hline CENRTC & 100 & 150 & 120 & 125 & -- & $\cdots$ & $\cdots$ & $\cdots$ & $\cdots$ & $4 y$ \\
\hline$\$$ & 200 & - - & - & -- & $\cdots$ & -- & - & - & $\cdots$ & 200 \\
\hline
\end{tabular}

The above costs were estimated from staff time required to complete the work in each fiscal year and knowledge of equipment costs for the leak detector and pump-down chamber. A detailed cost breakdown for this work wi $1 \bar{l}$ be prepared in FY $19 \bar{g} \bar{l}$. 
WHC-EP-0350

Table 5-5. Canister Leak Check Milestone List.

\begin{tabular}{|c|c|c|}
\hline Milestone & $\begin{array}{l}\text { Completion } \\
\text { date } \\
\text { (quarter/FY) }\end{array}$ & Milestone description \\
\hline 1 & $4 / 1991$ & $\begin{array}{l}\text { Assess requitrements for cantster leak check } \\
\text { and design, procure, and install plant } \\
\text { prototypic equipment for testing }\end{array}$ \\
\hline 2 & $2 / 1992$ & $\begin{array}{l}\text { Provide preliminary canister leak check } \\
\text { data/design information for HWVP Detatled } \\
\text { Design including canister first weld reject } \\
\text { frequency }\end{array}$ \\
\hline 3 & $2 / 1992$ & $\begin{array}{l}\text { Issue test plan for leak check equipment } \\
\text { qualification }\end{array}$ \\
\hline 4 & $4 / 1992$ & $\begin{array}{l}\text { Verify leak check equipment operability and } \\
\text { issue qualification report }\end{array}$ \\
\hline 5 & $4 / 1993$ & $\begin{array}{l}\text { Verify leak tightness of glass-filled } \\
\text { canisters produced during LFCM runs }\end{array}$ \\
\hline 6 & $4 / 1994$ & $\begin{array}{l}\text { Complete canister leak check verification } \\
\text { testing for HWVP readiness review and WFQ } \\
\text { compliance plan submittal }\end{array}$ \\
\hline
\end{tabular}

\subsubsection{Canister Decontamination (WBS: 1.2.2.04.06)}

5.2.3.1 Statement of Issue. The current reference process for HWVP canister decontamination uses an air-atomized frit/water slurry blaster designed for DWPF. Differences between HWVP and DWPF in the types of waste compositions and waste glass to be produced will require qualification of the range of HWVP frits for canister decontamination. A technical basis will need to be developed that allows acceptance of the frit compositions within the envelope selected from the glass QCR for operation of the canister frit-blaster equipment. Work under process development is being directed toward defining the acceptable envelope for HWVP feed and glass frit. The results of this study are needed to provide a range of frit compositions to be used for testing.

An assessment of the frit friability and dissolution behavior needs to be conducted in conjunction with frit composition variability previously discussed. This work will ensure that the frit will adequately decontaminate the canister and the physical properties will not deteriorate upon contact with water or formic acid. Data analysis and testing are needed to determine requirements for $\mathrm{pH}$ control in the RWCT to avold the possibility that the frit could set up if there is inadvertent loss of agitation.

Fluor has indicated that there could be a substantial HWVP cost savings by using the WVDP nitric acid/ $\mathrm{Ce}^{+4}$ canister decontamination approach. The cost savings would result primarily from reduced equipment requitrements and 
equipment simplicity. Fluor recommended that development studies be performed to further assess the adaptation of the $\mathrm{Ce}^{+4}$ decontamination system to HWVP and resolve a number of technical uncertainties.

Also, the $\mathrm{Ce}^{+4}$ decontamination process has not been tested for decontamination of radionuclides ( $1 . e ., \mathrm{Cs}^{137}$ ) that have undergone the cantster heating oxidation cycle. Further decontamination testing of contaminated cantster matertal coupons with $\mathrm{Cs}^{137}$ followed by heat treatment through a cantster heating cycle is needed.

5.2.3.2 Scupe. Work on frit performance assessment wi11 proceed based on the preliminary compositional envelope definition determined in FYS 1989 and 1990. Decontamination of heat-treated coupons using the $\mathrm{Ce}^{+4}$, cess will be conducted in FY 1990 to support the work planned by WVDP.

The scope of this issue includes the following activities.

- Determine an acceptable range for frit composition from glass statistical variability studies. Provide technical bases for frit acceptability. Procure frit of different compositions and measure physical properties, including friability, and dissolution behavior in water and formic acid, and conduct other tests as required to qualify acceptance. Verify frit behavior for decontamination in Taboratory tests as required.

- Monitor activities on the WVDP $\mathrm{Ce}^{+4}$ canister decontamination system. system design is expected to be completed in late FY 1990 , and a full-scale test system should be avallable in the first quarter of FY 1991 for process evaluation. Provide comments on the test plan to be prepared by WVDP. Current plans are to have PNL and HWVP staff participate in the testing at WVDP.

- Determine acceptability of the $\mathrm{Ce}^{+4}$ decontamination process for removal of contamination from oxidized coupons that have been heat treated through a normal canister heating cycle.

5.2.3.3 Status. Development work is in progress to define the acceptable envelope for major waste/frit components. A first-order statistical variability study was completed in FY 1990 and this information provides a definition of the preliminary limits for frit constituents. Work on this issue can be initiated based on the FY 1990 results and preliminary data from follow-on work initiated in FY 1991.

The WVDP selectrd the $\mathrm{Ce}^{+4}$ canister decontamination process based on data obtained from laboratory-scale testing. For canister decontamination, only laboratory-scale tests have been performed on stainless steel coupons. Fully oxidized coupons without radioactive contamination and radioactively contaminated coupons that have not been fully oxidized have been successfully decontaminated. Work conducted by PNL for WVDP determined there was no impact on the canister label and welds.

The WVDP w111 perform $\mathrm{Ce}^{+4}$ decontamination tests on full-size canisters in FY 1991. These tests will be monttored and results will be evaluated for applicability to HWVP canister decontamination. 
5.2.3.4 Remaining Tasks. Completion of the following tasks will close this issue.

- Review applicable information and ldentify laboratory studies necessary to compare HWVP and DWPF frit decontamination properties.

- Verify HWVP frit chemical, physical, and decontamination properties, as deemed necessary through laboratory-scale tests.

- Use the $\mathrm{Ce}^{+4}$ process to decontaminate a radioactive-contaminated metal coupon that has been fully oxidized by the cantster heat treatment cycle.

- Evaluate data obtained from the WVDP full-scale cantster decontamination system and provide a recommendation for Detalled Design.

5.2.3.5 Schedule Requirements. The range of frit compositions will be estabitshed based on preliminary definition of the QCR from work conducted in $\mathrm{FY}$ 1990. The $\mathrm{Ce}^{+4}$ process evaluation and recominendations should be completed by the end of FY 1992 for incorporation into the HWVP design with minimal impact. The milestones 1isted in Table 5-6 were established for closure of this issue (see Summary Schedule, Figure 11-1, in Section 11.0).

5.2.3.6 Costs. The following cost breakdown was established for this issue (expense dollars in thousands):

$$
\begin{array}{lrrrrrrrrrr}
\text { FY } & 91 & 92 & 93 & 94 & 95 & 96 & 97 & 98 & 99 & \text { Total } \\
\$ & 150 & 160 & \ldots & \ldots & \ldots & \ldots & \ldots & \ldots & \ldots & 310
\end{array}
$$

The estimated cost includes approximately $\$ 50,000$ for monitoring WVDP tests and providing funding support for additional testing and $\$ 100,000$ for radioactive coupon tests in FY 1991. Funding for FY 1992 is based on FY 1991 estimates.

\subsubsection{Canister Rework/Qualification (WBS: 1.2.2.04.07)}

5.2.4.1 Statement of Issue. The canister must meet requirements for closure, decontamination, dimensions, etc., for interim storage and for transport to, and acceptance by, a repository. If a canister is found unacceptable or unable to be closed or decontaminated, an approach to reworking or otherwise dealing with such a canister is needed. For example, there is the possibility of overfilling a canister with glass to the extent that the internal plug cannot be inserted. A means must be provided for rework of these cantsters for shipment to the repository. Rework could include overpacking, repairing a weld, or removing glass from an overfilled canister to permit closure. Any rework inethods adapted need to be defined and recommended to design.

5.2.4.2 Scope. This issue includes defining scerlarios that could lead to the need for canister rework, assessing the probability of the selected scenarios, selecting appropriate technology for canister rework, defining methods for treating unacceptable canisters, and performing any testing 
WHC - EP 0350

Table 5-6. Cantster Decontamination Milestone Litst.

\begin{tabular}{|c|c|c|}
\hline Mtlestono & $\begin{array}{l}\text { Completion } \\
\text { date } \\
\text { (quarter/FY) }\end{array}$ & Mtlestone description \\
\hline 1 & $2 / 1991$ & $\begin{array}{l}\text { Prepare a test plan for radioactive decon- } \\
\text { tamtnation evaluation of oxtdized stainless } \\
\text { steel coupons }\end{array}$ \\
\hline 2 & $3 / 1991$ & $\begin{array}{l}\text { Complete decontamination testing of oxidized } \\
\text { and radioactive-contaminated statnless steel } \\
\text { coupons using a } \mathrm{Ce}^{+4} \text { solution }\end{array}$ \\
\hline 3 & $2 / 1992$ & $\begin{array}{l}\text { Prepare a test plan for frit decontamtnation } \\
\text { testing }\end{array}$ \\
\hline 4 & $4 / 1992$ & $\begin{array}{l}\text { Determine frit properties over the range of } \\
\text { composttions to be used with the vartous HWW } \\
\text { waste types and vertfy cantster deccntamina- } \\
\text { tion acceptability for HWVP Detatled Design } \\
\text { and the WQR }\end{array}$ \\
\hline 5 & $4 / 1992$ & $\begin{array}{l}\text { Complete evaluation of the } \mathrm{Ce}^{+4} \text { canister } \\
\text { decontamination process for HWVP }\end{array}$ \\
\hline
\end{tabular}

necessary to demonstrate a rellable, remotely operable system. Consideration will be cliven to heat-generation measurement, nondestruct tve radioactive emission characterization, canister dimensional measurement, cantsters too full to permit normal closure, damaged cantsters, and canisters that fatl decontamination tests. Requirements for welding and canister charactertzation data wi1l be determined from the WAPS.

5.2.4.3 Status. The HWVP design does not include equipment for cantster rework and characterization. At DWPF, a repair weld method is being developed using the same upset resistance welder used for the primary weld. This technology will be transferred to the HWVP if the DWPF welder is selected by Fluor. Space has been allocated in the HWVP design for cantster overpacking. Work has not been initfated to identify a method for overpacking a cantster or to define a method of closing an overfilled canister.

5.2.4.4 Remaining Tasks. Completion of the following tasks will close this issue.

- Perform an engineering study to define needed cantster characterization equipment, estimate the frequency and type of canister rework required, evaluate alternative methods, and recommend preferred methods. This study will include a cost estimate for developing a canister overpack system, if rieeded.

- Conduct preliminary testing to demonstrate concepts or remote operability. 
- Develop a prototype remote cantster overpack system and conduct testing to demonstrate feasibility and provide data for the WFO compl tance report.

5.2.4.5 Schedule Requitrements. The engineering study is planned to be completed by the end of FY 1992 to support HWVP cell layout detalled destgn. The intlestones 1tsted in Table 5-7 were established for closure of this issue (see Summary Schedule, Figure 11-1, in Section 11.0).

5.2.4.6 Costs. The following cost breakdown was established for this issue (expense dollars in thousands):

$\begin{array}{lrrrrrrrrrr}\text { FY } & 91 & 92 & 93 & 94 & 95 & 96 & 97 & 98 & 99 & \text { Total } \\ \$ & \ldots & 200 & 240 & 90 & \ldots & \ldots & \ldots & \ldots & \ldots & 530\end{array}$

Costs are staff time estimates for work to be performed. A detalled cost breakdown for this work will be prepared at a later date.

\subsubsection{Glass Removal from Cantster (WBS: 1.2 .2 .04 .08 )}

5.2.5.1 Statement of Issue. Molten glass can fall onto and adhere to the exterior surface of a cantster during installation and/or removal of a canister under tho pour spout or bottom drain. Causes of glass dripping could be inadvertunt pressure surges, movement of cantsters too quickly after glass pouring is ;topped, equipment malfunction, and operator error. Adhered glass later separated from the canister (by thermal contraction, bumping, etc.) could contribute to contamination spread to other areas of the facility as canisters are moved through the process. A cantster with glass on the exterior would not meet storage requirements. As a result, technology for ident lfying the existence of glass on the canister surface and removing glass from the canister extertor must be defined and evaluated for design.

Table 5-7. Cantster Rework Milestone List.

\begin{tabular}{|c|c|c|}
\hline Mrlestone & $\begin{array}{l}\text { Completion } \\
\text { date } \\
\text { (quarter/FY) }\end{array}$ & Mllestone description \\
\hline 1 & $4 / 1992$ & $\begin{array}{l}\text { Complete an engineering study of cantster } \\
\text { rework methods and provide a recommendation } \\
\text { for HWVP Detalled Design }\end{array}$ \\
\hline 2 & $4 / 1993$ & $\begin{array}{l}\text { Complete preliminary testing of alternative } \\
\text { concepts for canister rework/overpacking }\end{array}$ \\
\hline 3 & $4 / 1994$ & $\begin{array}{l}\text { Complete testing of selected method(s) and } \\
\text { provide data for the WFQ compl lance report, } \\
\text { WQR, and HWVP readiness review }\end{array}$ \\
\hline
\end{tabular}


5.2.5.2 Scope. The scope of this effort includes identification of acceptable glass detection and removal methods and, if necessary, testing of the method.

5.2.5.3 Status. Relevant studies regarding glass removal from a cantster surface have been conducted by OWPF staff. Techniques evaluated include spot-frit blasting and use of an ultrasonic needle gun. For some tests, removal of the glass has been unsatisfactory or the method has produced unacceptable damage to the canister. No work has been conducted to evaluate a method for removal of glass from a canister by HWVP.

5.2.5.4 Remalning Tasks. Completton of the following tasks wtll close this issue.

- Review technologies for tdentifying existence and locatton of glass deposits on the surface of a cantster and select the method to be used for HWVP. Further work under this task is dependent on successful selection of a method for locating glass deposits under plant operating condtitions.

- Review technologies for remotely removing solidffled and adhered glass from the extertor surface of a stainless steel canister. Identffy technology development needs to ensure the following:

- Adequacy of glass removal

- Adaptability to remote handling techniques

- Canister fotegrtty remains within acceptable 1 imits.

- Identify and vertfy a suttable process or select candidate process(es) for evaluation. Assess process adaptabllity to remote handling requiremenls, and develop conceptual remote design requtrements for the system. Report selection and testing results, and prepare a conceptual design.

- Procure equipment and perform testing, as requited, to verify acceptable performance of the seleci.'d method for glass removal. Initial testing would entall preparing stainless steel canisters, or a portion thereof, with adhered, simulated HWVP glass under a range of glass and stainless steel temperatures (temperatures affect how tightly the glass will adhere to the metal). Compare methods for glass removal and evaluate samples for metal damage.

5.2.5.5 Schedule Requirements. Equipment selection must be resolved by the end of FY 1991 to permit detailed equipment and support services design. The milestones 1 isted in Table 5-8 were established for closure of this issue (see Silmmary Schedile, Figure 11-1, in Section 11.0). 
Table 5-8. Glass Remoyal from Cantster Mllestone List.

\begin{tabular}{|c|c|c|}
\hline Mllestone & $\begin{array}{l}\text { Completion } \\
\text { date } \\
\text { (quarter/FY) }\end{array}$ & Milestone description \\
\hline 1 & $4 / 1991$ & $\begin{array}{l}\text { Complete engtneerting study for glass removal } \\
\text { from cantsters and provtde recommendattons } \\
\text { for test equtpment }\end{array}$ \\
\hline 2 & $4 / 1991$ & $\begin{array}{l}\text { Procure glass detection and removal } \\
\text { equipment }\end{array}$ \\
\hline 3 & $2 / 1992$ & $\begin{array}{l}\text { Issue a test plan for glass detection and } \\
\text { removal studies }\end{array}$ \\
\hline 4 & $4 / 1993$ & $\begin{array}{l}\text { Complete testing and provide data for WFQ } \\
\text { compliance plan and WFQ report subinttals }\end{array}$ \\
\hline
\end{tabular}

5.2.5.6 Costs. The following cost breakdown was established for this issue (dollars in thousands):

\begin{tabular}{|c|c|c|c|c|c|c|c|c|c|c|}
\hline $\begin{array}{l}\text { Fy } \\
\text { :xpense }\end{array}$ & 91 & 92 & 93 & 94 & 95 & 96 & 97 & 98 & 99 & Total \\
\hline ENRTC & 50 & 175 & 120 & $\ldots$ & - & $\cdots$ & $\cdots$ & - & $\ldots$ & 345 \\
\hline$\$$ & 50 & -- & $\cdots$ & ـ & 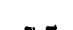 & 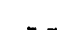 & $\tilde{z}$ & 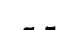 & - & 10 \\
\hline
\end{tabular}

These cost.s were estimated from staff time needed to complete the required studies and rough estimates for equipment that may be procured to accomplish this work.

\subsection{MATERIALS EVALUATION (WBS: 1.2.2.04.09)}

\subsubsection{Statement of Issue}

The HWVP is being designed to pracess a variety of chemically diverse wastes stored at the Hanford Site. Proper materials selection is essential to ensure that materials used for fabrication of remote process equipment in the HWVP will be compatible with expected waste stream compositions and processing conditions. A materials veriffcation test report was issued near the end of FY 1990 to support HWVP Detalled Design and provide a basis for selecting materials to be used for vartous process equipment.

Subsequent material issues involve the erosion of the lower impeller and colls of the feed processing vessels and life expectancy of the slurry pumps. Data are needed to evaluate equipment life and posslble design changes to timprove performance. 
WHC-EP-0350

The current life expectancy of dip tubes and thermowells in the melter is also limited. Investigation of material coatings during melter runs is needed to determine if significant improvements in reliability of these components could be realized, thereby reducing costly melter maintenance.

\subsubsection{Scope}

Specific efforts within the scope of this activity include the following:

- Conduct long-term verification testing of reference materials under realistic process conditions in conjunction with integrated testing of the full-scale feed preparation system and melter runs. Materials testing will evaluate corrosion and erosion phenomena associated with the pumps, agitators, coils, and the tank of the full-scale feed preparation test system. The MOG system, film cooler, and offgas line also are to be evaluated.

- Evaluate material options for melter instrument components.

\subsubsection{Status}

The reference alloy selected for feed piping and processing vessels and some of the offgas equipment in the DWPF is Hastelloy C-276.* The offgas line from the melter to the first stage of quenching is Inconel 690 . Testing at the SRS, WVDP, and by PNL for HWVP has shown that these alloys have high corrosion/erosion resistance compared to other available materials. Much of the DWPF data are suitable for the HWVP. For some systems, however, specific testing was required to verify compatibility with HWVP processing streams.

Recommendations for materials of construction for remote process equipment and piping for the HWVP, including supporting documentation, were provided in FY 1990. Subsequent work in materials evaluation will be focused on verification of operation performance and determining the expected life of pumps, agitators, tank coils, MOG line, and the melter dip tubes and thermowells. Plans are to evaluate erosion/corrosion in the full-scale feed preparation system equipment that will be used for integrated testing.

Improvements in dip tube and thermowell life could reduce melter downtime for change-out of these failure-prone components. Possible improvements in operating life could be achieved at minimum cost through the development of protective coatings.

*Hastelloy is a trademark of Haynes International, Kokomo, Indiana. 
WHC -EP- 0350

\subsubsection{Remaining Tasks}

Completion of the following tasks will close this issue.

- Monitor erosion/corrosion of the full-scale feed preparation equipment including coils, agitator, and vessel appurtenances on the bottom inside surface. Determine wear of feed and sample pumps for various processing conditions.

- Conduct material tests on typically short-lived melter instrument components (dip tubes and thermowells) and other test equipment during integrated testing and melter idling. Evaluate materials coatings as appropriate.

\subsubsection{Schedule Requirements}

Monitoring of feed processing equipment to verify erosion/corrosion performance will be continued to FY 1994. Material recommendations for shortlived melter components will be provided in FY 1994. The milestones listed in Table 5-9 were established for closure of this, issue (see Summary Schedule, Figure 11-1, in Section 11.0).

Tabie 5-9. Materials Evaluation Milestone List.

\begin{tabular}{|c|c|c|}
\hline Milestone & $\begin{array}{l}\text { Completion } \\
\text { date } \\
\text { (quarter/FY) }\end{array}$ & Milestone description \\
\hline 1 & $1 / 1991$ & $\begin{array}{l}\text { Issue feed preparation system materials test } \\
\text { plan }\end{array}$ \\
\hline 2 & $2 / 1991$ & $\begin{array}{l}\text { Complete study of materials coatings for } \\
\text { melter application and issue recommendation } \\
\text { and plan }\end{array}$ \\
\hline 3 & $4 / 1991$ & $\begin{array}{l}\text { Obtain coated coupons and melter components } \\
\text { aild test in the LFCM run }\end{array}$ \\
\hline 4 & $4 / 1992$ & $\begin{array}{l}\text { Provide preliminary data on SRAT/SME coil } \\
\text { and agitator wear and melter feed pump wear } \\
\text { for Detailed Design }\end{array}$ \\
\hline 5 & $4 / 1992$ & $\begin{array}{l}\text { Test material coatings for short-lived melter } \\
\text { components and provide information for melter } \\
\text { Detailed Design }\end{array}$ \\
\hline 6 & $4 / 1993$ & $\begin{array}{l}\text { Continue evaluation of materials coatings } \\
\text { for melter components and report results }\end{array}$ \\
\hline 7 & $4 / 1994$ & $\begin{array}{l}\text { Complete verification evaluation of SRAT/SME } \\
\text { component wear and melter component improve- } \\
\text { ments for HWVP equipment procurement and } \\
\text { readiness review }\end{array}$ \\
\hline
\end{tabular}


WHC -EP - 0350

\section{3 .6 Costs}

The following cost breakdown was established for this issue (expense dollars in thousands):

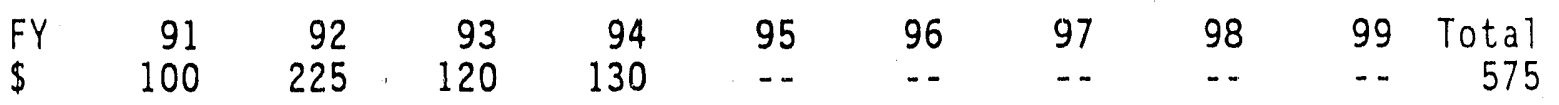

The cost breakdown is based on a funding level for each fiscal year to provide staff time, materials, and vendor support for coatings application on hardware. Minimal funding support is also provided for material thickness measurements and subsequent evaluation.

\subsection{OFFGAS LINE PLUGGING (WBS: 1.2 .2 .04 .10 )}

\subsubsection{Statement of Issue}

Melter particulate emissions during operation are expected to build up in the vicinity of the film cooler and could potentially plug up the MOG line if measures are not taken to keep the line cleared. A plugged MOG line would eventually cause process operation shutdown. The steam and air flow rates specified for the MOG system design are expected to provide sufficient velocity to prevent particulate buildup in the long line connected to the SBS. Testing has shown that the film cooler is effective in preventing offgas line deposit accumulation. Nevertheless, deposits are expected to build up at the inlet of the film cooler and at a location just downstream from this device. A brush that will periodically clean the film cooler has been recommended for the HWVP offgas line. There has been no testing of a prototypic DWPF brush system at the Hanford Site. It may be possible to redesign the film cooler inlet to direct air flow so troublesome fouling conditions could be eliminated.

\subsubsection{Scope}

The offgas line solids deposits form at the inlet of the film cooler and at a location downstream of this device. The inlet of the film cooler needs to be designed so properly directed air flow will alleviate troublesome fouling conditions and minimize the use of a brush cleaner device. Resolving this issue involves verifying the performance of the film cooler designed and installed on the LFCM offgas line. Also included in this scope is the design, fabrication, and testing of a film cooler reamer to be installed on the LFCM offgas line and evaluated during LFCM tests in FY 1991. Using some steam with air in the film cooler has shown some potential for reducing solids buildup at the SRS. This concept will be tested in an LFCM run.

\section{4 .3 Status}

The film cooler design has gone through several stages of development and MOG line testing. The inlet to the film cooler has been examined and modified to minimize the growth of troublesome deposits. In FY 1990, the 
LFCM film cooler was designed and constructed to inject gas near the tip of the film cooler that extends into the melter to minimize or eliminate the buildup of solids in that area. The film cooler performance will be tested as part of the FY 1991 LI LM run. Reamer/brushes have been added to the MOG jumper design specifically to mitigate inlet blockage problems. The reamer design uses an offgas line tee that changes the process exhaust flow which may create a new set of offgas line plugging problems. New film cooler designs, which protect the vulnerable inlet section with a fluid sheath, show promise but have not been developed. Considerable work has been conducted at DWPF to solve jumper blockage problems that occur downstream of the film cooler through increases in air flow and use of steam to reduce maximum line temperature and obtain higher velocity. To alleviate solids buildup around the brush entrance area to the offgas line, the right-angle turn has been changed to a curved shape in the LFCM offgas line.

\subsubsection{Remaining Tasks.}

Completion of the following tasks will close this issue.

- Design, procure, and install a DWPF-type reamer/brush for the LFCM offgas line.

- Evaluate DWPF, WVDP, and PNL film cooler and offgas line blockage experience as applied to HWVP including evaluation of the DWPF proposed solution. Demonstrate the solution under HWVP conditions in conjunction with LFCM testing as required.

\subsubsection{Schedule Requirements}

This issue will be resolved in conjunction with other offgas system issues and LFCM testing. Recommendations are needed by the end of FY 1992 for detailed design of the film cooler and offgas line. The milestone listed in Table 5-10 was established for closure of this issue (see Summary Schedule, Figure 11-1, in Section 11.0).

Table 5-10. Offgas Line Plugging Milestone List.

\begin{tabular}{ccc} 
Milestone & $\begin{array}{c}\text { Completion } \\
\text { date } \\
\text { (quarter/FY) }\end{array}$ \\
\hline 1 & $4 / 1991$ & $\begin{array}{l}\text { Procure and install film cooler reamer on } \\
\text { the LFCM and test operation during the } \\
\text { FY 1991 melter run }\end{array}$ \\
2 & $\begin{array}{l}\text { Complete experimental evaluation of the film } \\
\text { cooler reamer for the HWV melter and offgas } \\
\text { system detailed design }\end{array}$ \\
\hline
\end{tabular}




\subsubsection{Costs}

Film cooler testing costs for FY 1991 are included in Section 4.4. Film cooler reamer design, construction, and testing costs are shown in the following cost breakdown (expense dollars in thousands):

$$
\begin{array}{lrllllllllr}
\text { FY } & 91 & 92 & 93 & 94 & 95 & 96 & 97 & 98 & 99 & \text { Total } \\
\$ & 200 & 50 & -- & -- & -- & -- & \ldots & \ldots & \ldots & 250
\end{array}
$$

These costs are based on a rough-order-of-magnitude estimate of the cost for the equipment assuming minimal cost for installation since the LFCM offgas line has an available flange for insertion.

\subsection{ANALYTICAL METHODS (WBS: 1.2 .2 .04 .11 )}

\subsubsection{Statement of Issue}

The current design of the HWVP Analytical Laboratory is based on using new laser ablation ICP.-MS technology for analysis of slurry and glass samples. Plans are to install a portion of the ICP-MS apparatus in the hot cell with sensitive readout instruments available for manual maintenance. The laser ablation ICP-MS has the potential advantage of direct sample analysis through elimination of the analytical steps of peroxide fusion and subsequent dissolution and dilution to obtain the elemental data for the HWVP slurry and glass samples.

A thorough development study i@ needed to assess the ultimate instrument capabilities using glass standards. The objective of this work would be to improve the current precision capability of this instrument from plus or minus 15 percent to plus or minus 3 to 6 percent. This would be in the range of the normal precision for an ICP-MS using a liquid nebulizer. If this development work is successful, additional effort will be needed to evaluate ways to incorporate the ICP-MS into a hot cell. As a final step in determining the acceptability of the laser ablation ICP-MS for the HWVP, the instrument needs to be installed in a hot cell and utilized for analysis of radioactive slurry and glass samples.

Further work is also needed to determine the radionuclides that will be obtaired using ICP-MS and/or counting techniques. Equipment must be selected for the HWVP Analytical Laboratory and the analytical error for the chosen methods must be determined to provide data for the WQR.

\subsubsection{Scope}

The scope of this task will include development work to achieve the following objectives.

- Measure precision and accuracy using an existing PNL laser ablation ICP-MS with simulant slurry and glass samples and compare these data to measurements obtained using a normal ICP-MS. 
- Evaluate ways to install the instrument in a hot cell, including methods to be used for periodic maintenance.

- Select equipment for radionuclide analysis and determine analytical error for data reporting.

- Install and operate a laser ablation ICP-MS in a hot cell with background radiation to verify capabilities for use in the HWVP.

Radioactive waste tank core samples and radioactive glasses prepared from these samples will be available for testing of the instrument when hot cell installation is complete.

\subsubsection{Status}

Initial investigation of the capabilities of the laser ablation ICP-MS equipment have been conducted by PNL. Work indicates the laser was not sufficiently robust to vaporize and completely ionize the slurry and glass samples; however, work at commercial analytical laboratories has been successful on a variety of materials. Various gas mixtures have been investigated to improve the sensitivity, but the gases have a corresponding impact on pumping and transport efficiency. Work initiated in FY 1991 would be directed to determine the feasibility of using the laser ablation ICP-MS for slurry and glass samples analyses and comparing results to results obtained with dissolved samples. If this effort is successful, further development work would be focused on techniques for hot cell installation and verification testing.

\subsubsection{Remaining Tasks}

Completion of the following tasks will close this issue.

- Investigate various conditions for operating the laser ablation ICP-MS and determine the optimal precision and accuracy that is obtainable with this instrument.

- Work with equipment vendors and prepare hot cell layouts that take into account instrument breakdown to provide for periodic maintenance from within the hot cell on essential components and maximize manual "hands-on" maintenance of sensitive components.

- Install and operate a laser ablation ICP-MS in the PNL 325 Building hot cells, analyze radioactive slurry and glass samples, and obtain precision and accuracy for comparison with dissolved sample results.

\subsubsection{Schedule Requirements}

The milestones listed in Table 5-11 were established for closure of this issue (see Summary Schedule, Figure 11-1, in Section 11.0). 
WHC-EP-0350

Table 5-11. Analytical Methods Milestone List.

\begin{tabular}{ccl}
\hline Milestone & $\begin{array}{c}\text { Completion } \\
\text { date } \\
\text { (quarter/FY) }\end{array}$ & \multicolumn{1}{c}{ Milestone description } \\
\hline 1 & $2 / 1991$ & $\begin{array}{l}\text { Issue test plan for laser ablation ICP-MS } \\
\text { evaluation of slurry and glass samples }\end{array}$ \\
2 & $4 / 1991$ & $\begin{array}{l}\text { Complete laser ablation ICP-MS testing to } \\
\text { determine prectsion and accuracy us'ting } \\
\text { slurry and glass samples }\end{array}$ \\
3 & $2 / 1992$ & $\begin{array}{l}\text { Prepare initial hot cell layout and review } \\
\text { instrument breakdown and maintenance with } \\
\text { Fluor for HWVP utilization }\end{array}$ \\
4 & $4 / 1992$ & $\begin{array}{l}\text { Complete plans for installation of a laser } \\
\text { ablation ICP-MS in the 325 Butlding hot } \\
\text { cells }\end{array}$ \\
6 & $1 / 1993$ & $\begin{array}{l}\text { Provide data for radionuclide analysis } \\
\text { including analytical error evaluation to } \\
\text { Fluor } \\
\text { Complete 325 Building installation of a }\end{array}$ \\
7 & $4 / 1993$ & $\begin{array}{l}\text { laser ablation ICP-MS and verify capabilities } \\
\text { on radioactive slurry and glasses } \\
\text { Complete laser ablation ICP-MS testing }\end{array}$ \\
\hline
\end{tabular}

\section{5 .6 Costs}

The following cost breakdown was established for this issue (expense dollars in thousands):

$$
\begin{array}{lrrrrrrrrrr}
\text { FY } & 91 & 92 & 93 & 94 & 95 & 96 & 97 & 98 & 99 & \text { Total } \\
\$ & 95 & 150 & 200 & 100 & -- & -- & -- & -. & -- & 545
\end{array}
$$

These cost projections are estimates of the staff time required to accomplish work planned for each fiscal year. No costs have been established at this time for procurement of a laser ablation ICP-MS for hot cell installation (CENRTC funding). 


\subsection{WASTE FORM QUALIFICATION - PACIFIC NORTHWEST LABORATORY \\ (WBS: 1.2 .2 .05 .00$)$}

With in the HWVP integrated management structure, WFQ activities have been divided between Westinghouse Hanford and PNL. The Westinghouse Hanford work includes overall management of WFQ work, interfacing with sources outside of HWVP concerning waste acceptance requirements, and developing design requirements to ensure the facility can produce a qualified product. The PNL activities include model development, product and process testing, and technical support. bases.

The WFQ scope, costs, and schedule are provided using the following

- Pretreatment technology development for NCRW and CC and PFP wastes started in FY 1990. Pretreated NCRW, NCAW, and CC and PFP wastes are available for radioactive confirmation tests in FYs 1995 through 1998.

- A new "generic" WAPS that will be applicable to the HWVP will be issued by no later than the fourth quarter of FY 1991.

- The "generic" WAPS will be nearly the same as OGR/B-8, Waste Acceptance Preliminary Specifications for the Defense Waste Processing Facility High-Level Waste Form (DOE-OCRWM 1986) with appropriate modifications to accommodate the Hanford waste types.

- A TRG Will review the preliminary HWVP WQR by the second quarter of FY 1998 and final approval of the WQR will be obtained by the third quarter of FY 1999.

- The HWVP cold qualification runs will be initiated during the first quarter of FY 1998 to provide data that will demonstrate compliance to the regulatory agencies.

- Facilities are avallable at the Hanford Site from FYs 1990 through 1999 for laboratory-scale radioactive confirmation testing of all HWV feed types. Radioactive bench-scale melter testing will be initiated by the third quarter of 1995.

The WFQ Planning and Technical Coordination subtask provides for the administrative and technical direction of the WFQ Support task. The subtask also provides for application of DOE/RW-0214 (DOE-OCRWM 1990) QA requirements and related procedures to appropriate WFQ activities, and for coordinating with HLW program activities related to chemical and radiochemical analyses of radioactive core samples. This task also includes development of plans and schedules for data collection from the HWVP process development, equipment adaptation and testing, systems integration, and startup testing efforts. 
WHC-EP-0350

The WFQ task will extract information from a number of test programs to develop the information necessary to support the major HWVP WFQ activities. Subtask plans include the use of the available test data to support the following documentation:

- HWVP waste form and canister description

- WCP

- WFQ report

- Plant WFQ design criteria

- Plant WFQ operating criteria.

The following cost breakdown was developed for planning and coordination of the PNL WFQ activities (expense dollars in thousands):

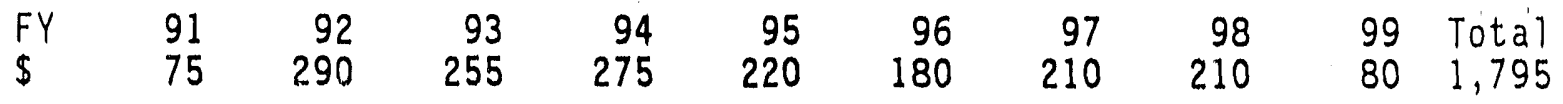

The PNL will perform the activities described in this Plan as support to the HWVP WFQ program. The Hanford Waste Vitrification Plant Preliminary Waste Form Qualification Plan - FY 1988 Update (WHC-EP-0045) (Nelson 1988) describes the entire scope of Project activities required to ensure WFQ compliance.

\subsection{PRODUCTION CONTROL AND PRODUCT QUALIFICATION}

The HWVP Project must develop the technical approach to (1) monitor and control the production of glass satisfying the WAS, (2) describe and defend the technical approach in its WCP and WQR, and (3) describe in production records the actual results of monitoring and controlling during operation of the plant.

The technical approach adopted to attain the above goals is based on monitoring and controlling the composition of the glass. The elemental inventories, radiochemical inventories, durability, internal temperature during storage, inertness relative to the canister material, heat generation rate, and dose rate of glass in a canister can all be determined as functions of the composition of the glass. Consistent with the technical approach implemented at DWPF and WVDP, the HWVP techinical approach is to (1) control the composition of the feed slurry exiting the SME, (2) maintain conditions in the SME, MFT, and melter so they behave as well-mixed tanks, and (3) invoke mass balances and analytical sampling techniques to optimally estimate (using statistical methods) the compositions in tanks in the feed system, melter, and canister.

Operation in accordance with the above technical approach will require several algorithms to be used during operation to control transfers of material from tank to tank. First, a mass balance model (MBM) must be avallable to optimally estimate from process data the composition of several 
tanks at une or more stage: in the operational sequence for the tank. Second, algorithms responding to estimates of composition must be available that (1) compute the mass of fresh frit to add to the SME to create the desired feed, (2) determine if the conterits of the SME are acceptable for transfer to the MFT, and (3) compute what to add to the SME to correct its contents if they are found to be unacceptable for transfer to the MFT. The MBM and the three control algortthms must be implemented as software for use during operation of the plant.

To evaluate and defend the technical approach, the sufficiency of the MBM and control algorithms to meet the WAS must be determined in terms of the extent of sampling and sample chemical analysis results. This evaluation will be achieved through a combination of testing feed system components, testing an integrated feed system (e.g., during nonradioactive operation of the HWVP), and simulating operation of the HWVP. The latter requirement is being implemented using a computer code currentiy denoted the waste form qualification simulation model (WSM).

The WSM will be used prior to operation of the plant, and the results will appear in, or support, the WQR. Unlike the MBM and control algorithms, the WSM will not become part of software used to operate the plant. However, the MBM and control algorithms must be inserted into the WSM so the consequences of using them can be simulated. The combined result of the technical approach will be input to the WQR of (1) direct observations during operation of the process of the consequences of the MBM and control algorithms for a limited set of process situations (probably only nominal operation) and for a limited time period; and (2) simulated consequences of the MBM and control algorithins for a larger set of process situations (e.g., simulated drift or failure of instrumentation) and for long time periods (e.g., a year of operation).

During operation of the plant, process data and also information generated in using the control algorithms can be used to monitor the control of feed preparation and glass production operations. In particular, methods such as process control charting can be applied to infer from perturbations in process data whether a shift of some kind has occurred that requires corrective action or whether the cbserved perturbations are random and acceptable. An algorithm must be developed to monitor the process operations and be included in software used during operation of the plant. The monttoring algorithm and a set of procedures describing proposed corrective responses to any off-normal conditions revealed by the monttoring algorithm must be inserted into the WSM to allow the efficiency of the monitoring and correction strategy to be simulated, evaluated, and defined in the WQR.

Formulation of the control algorithms requires a quantitative understanding of the dependence of certain chemical and physical properties of the glass on its composition. This understanding is obtained from the results of the QCR studies. Additional work is required to provide correlations between glass composition and properties addressed in the WAS, such as devitrification kinetics, and to provide correlations or models relating the cooling history in a canister to the lifstory of the pour rate and pour temperature for that canister. 


\subsubsection{Product Models (WBS: 1.2.2.05.01)}

6.1.1.1 Statement of Issue. The WAPS 1.3 (DOE-OCRWM 1986) requirement is being addressed through WAPS subsection 1.3.3, which allows the durability of the glass as defined by WAPS Subsection 1.3.1 to be demonstrated by means other than directly testing the glass produced. Compliance with WAPS 1.3 can be based on estimating the composition of the glass if the composition of the glass can be related to the appropriate measure of durability of the glass. Empirical modeling is underway as part of the glass envelope definition studies, where the durability measured in a specified test is correlated to glass composition using standard linear and quadratic fits to mixture effects. The uncertainty remaining after fitting the data in this manner detracts from the ability to show compliance with WAPS

Subsection 1.3.2, which requires demonstrating that 95 percent of the glass produced is acceptable as determined at the 95 percent confidence level.

A large number of compositions need to be tested because the mathematical form of the correlation has no theoretical foundation, such that the correlation cannot safely be extrapolated beyond the domain of the compositions studied or interpolated to points lying between widely separated test compositions. The set of durability data used to develop the correlation is not easily compared to, or extended by, data from a different standard test, e.g., MCC -1 versus a product consistency test (PCT), because no presumption about physical or chemical truths is explicitly incorporated into the correlation with composition. Similarly, no basis is provided for reconcliling any seemingly inconsistent data from different tests, projects, or laboratories.

Consequent1y, there is a need to improve the functional form of the model fit to the QCR data set, and to link the QCR data set to other existing data to provide maximum benefit to the HWVP from other work funded by the DOE. The result will be a product durability model used to demonstrate compliance with WAPS 1.3 .

A functional form for correlating durability with composition can be obtained by combining a rate law for the inherent durability (i.e., independent of test definition) of glass as a function of composition with existing, mature geochemical models (e.g., PHREEQE, EQ3/EQ6) describing chemical behavior in leach solutions during testing. A rate law correlates the instantaneous dissolution rate as a function of instantaneous composition of the leach solution. The dissolution rate law can be obtained by measuring the rate of dissolution of the glass at very short times before dissolution begins to change the initial composition of the leach solution, and correlating the observed rate with the initial composition of the leach solution.

Once the rate law is defined, it can be combined with a geochemical model and QCR test results and with other pertinent existing data to obtain a semi-theoretical model combining the QCR data set with existing knowledge about the chemistry and kinetics of the hydration of glass. If, in the future, the specification of the measure of durability changes, e.g., such as the change from MCC-1 to PCT, or if the Project is required to relate the measure of durability to performance in a repository, the dissolution rate law could be invoked. The law could be used to answer questions in terms of glass composition with a minimum of, or possibly no, additional testing. 
Product models also include algorithms that compute glass quality characteristics required in the WAPS such as heat generation rate, dose rate, and $\mathrm{K}_{\text {eff }}$ (subcriticality value). Existirig algorithms developed by Westinghouse Hanford may be used for the latter three items, but PNL activities may involve verification and validation. The models will be provided as part of the WQR and be used in plant operation to infer (determine) product quality and final product properties.

6.1.1.2 Scope. The activities required for the colosure of this issue include development of the following product models.

- Product Durability Model--A provisional rate law describing glass dissolution rate as a function of both glass composition and leach solution composition will be combined with an existing, mature, geochemical model. The resulting combination will be used to interpret the QCR data set and validate or modify the rate 1 aw unt 11 an acceptable fit to the QCR data set and to other pertinent, existing data is obtained. The resulting correlation will be used to update a subroutine predicting the performance of the glass that will be used during operation of the HWVP to show compliance with WAPS 1.3.

- Heat Generation, Dose Rate, and Subcriticality--Adaptation of existing algorithms will be required to translate radiochemical glass constituents into glass heat generation rate (ORIGN), dose rate (ISOSHLD), and subcriticality value. Heat generation, dose rate, and production of radiogenic gases will be computed given the composition, density, and configuration of the glass and canister. These properties must be reported for WFQ as required by WAPS 3.7, 3.8 , and 3.10 (DOE-OCRWM 1986).

6.1.1.3 Status. Leach testing results obtained on a nominal NCAW glass have been reported (Bates et a1. 1989). In FY 1990, a preliminary empirical durabllity model was developed from the first-order glass envelope definition data. The results indicated the need for more data to improve model accuracy. A review of application of the "free energy" model and "Grambow's" model to predict glass leach rates indicated an unsatisfactory correlation.

The MBM is being developed by PNL to track the waste composition and radiochemical components for determination of the canister heat generation, dose rate, and subcriticality value using existing cudes. The MBM is operational but needs to be modified to incorporate statistical approaches to determine true process stream compositions and volumes and to speed up run time. Existing shielding, criticality, and thermal codes will be used as base algorithms to estimate dose, subcriticality, and heat generation for the canisters.

\subsubsection{Remaining Tasks. Completion of the following tasks will close this} issue.

- Complete the product durability models.

- Validate the product durability model by comparison of model durability predictions with data from process development QCR MCC1 and PCT durability tests. Correlate results with data from actual 
radioactive glass produced from waste tank core samples and radioactive bench-scale testing that are not generated as part of the QCR.

- Apply existing source term (ORIGIN), shielding (ISOSHLD), and criticality codes to determine filled canister neat generation, dose rate, and subcriticality assessment $\left(K_{e f f}\right)$. These codes will have been validated through previous use.

- Provide product models for the HWVP MIS computer and support HWVP cold startup model verification and validation.

6.1.1.5 Schedule Requirements. The milestones listed in Table 6-1. were established for closure of this issue (see Summary Schedule, Figure 11-1, in Section 11.0).

6.1.1.6 Costs. The following cost breakdown was established for this issue (expense dollars in thousands):

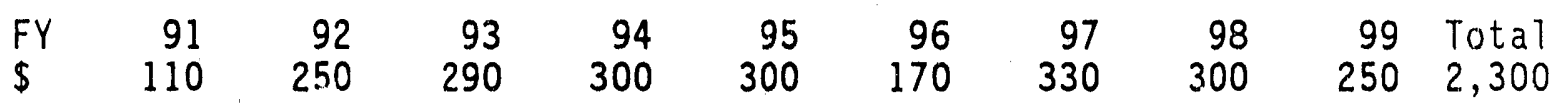

These costs provide a staff time level-of-effort to complete the milestones for this task.

\subsubsection{Process Models (WBS: 1.2.2.05.02)}

6.1.2.1 Statement of Issue. Process models must be developed to accomplish the following requirements.

(1) Estimate the mass of chemical species in various tanks in the feed system based on analytical sampling and tank level and specific gravity process measurements i.e., the MBM. The results are used as input to (2), (3), (4), and (6) below.

(2) Compute the amount of fresh frit slurry to add to the SME to produce an acceptable feed (frit addition algorithm).

(3) Determine if the contents of the SME as determined using the MBM are acceptable for transfer to the MFT (feed acceptability test algorithm).

(4) Compute the amount and composition of slurry in chemical adjustment tanks to be added to the SME to correct the contents of the SME whenever they are found to be unacceptable by (3) (feed adjustment algorithm).

(5) Present the results of (1), (2), (3), and (4) as a graphical display suitable for use by operators in operating the plant (product composition control graphics). 
WHC -EP-0350

Table 6-1. Product Models Milestone List.

\begin{tabular}{|c|c|c|}
\hline Milestone & $\begin{array}{l}\text { Completion } \\
\text { date } \\
\text { (quarter/FY) }\end{array}$ & Milestone description \\
\hline 1 & $2 / 1991$ & $\begin{array}{l}\text { Issue renort on testing of rate law of } \\
\text { Grambow model }\end{array}$ \\
\hline 2 & $4 / 1991$ & $\begin{array}{l}\text { Complete initial correlation of rate law } \\
\text { with QCR and other DOE site test data }\end{array}$ \\
\hline 3 & $4 / 1992$ & Complete initial durability model \\
\hline 4 & $3 / 1993$ & $\begin{array}{l}\text { Complete development of dose, subcriticality, } \\
\text { and heat generation aigorithms }\end{array}$ \\
\hline 5 & $4 / 1994$ & Complete validation of durability model \\
\hline 6 & $4 / 1995$ & $\begin{array}{l}\text { Complete durability model conversion for } \\
\text { HWVP MIS }\end{array}$ \\
\hline 7 & $4 / 1996$ & $\begin{array}{l}\text { Complete validation of dose, subcriticality, } \\
\text { and heat generation algorithms }\end{array}$ \\
\hline 8 & $4 / 1997$ & $\begin{array}{l}\text { Assist with implementation of product models } \\
\text { and computer programming in HWVP MIS for } \\
\text { readiness review and startup }\end{array}$ \\
\hline 9 & $4 / 1999$ & $\begin{array}{l}\text { Complete application of product models to } \\
\text { support HWVP startup }\end{array}$ \\
\hline
\end{tabular}

DOE = U.S. Department of Energy

(6) Implement multivariate statistical process control monitoring (e.g., "charting") to determine if perturbations in process data are random and acceptable or if they indicate shifts or failures in process equipr.ent that must be corrected (product composition control monitoring).

(7) Simulate the operation of the HWVP using (1), (2), (3), (4), and (6), other HWVP operating procedures, and a specified repetition of sampling and chemical analysis to predict if the consequence of these would result in compliance with WAPS 1.3 and to report this prediction in the WQR before operation of the plant.

(8) Correlate the cooling history in a canister with the history of the pour rate and pour temperature while filling a canister. This will be used to interpret a time-temperature-transformation (TTT) diagram for the glass in the WQR. 
6.1.2.2 Scope. The activities required for the closure of this issue include development, verification, review, and configuration control for items (1) through (7) listed in Section 6.1.2.1. All items except (7) and (8) need to be implemented as software running on the appropriate host computer facility at the plant. Item (8) will be provided by correlating applicable DWPF, WVDP, and HWVP data obtained by filling full-size prototype canisters instrumented with thermocouples.

6.1.2.3 Status. A WSM (Item 7) has been developed at PNL. An MBM (Item 1) is being developed for inclusion into the WSM. A statistical technique ("measurement error modeling") similar to Kalman filtering, but which is simpler and more straightforward in its treatment of measurement errors, i.s being developed.

A product composition control system (PCCS) has been developed in support of the DWPF. The PCCS includes a provisional MBM (Item 1) based on a Kalman filtering scheme and product composition control graphics (Item 5). Provisional forms of a frit addition algorithm (Item 2) and feed acceptability test algorithm (Item 3 ) are included to illustrate the use of the control graphics. Final implementations of Items (2), (3), and (4) are being developed in conjunction with responses to comments from the TRG reviewing DWPF WFQ documentation.

The PCCS also includes a simulation of the DWPF plant. This software is being imported into the HWVP Project. During FY 1991, the PCCS simulation capability will be evaluated to determine if it can serve the functions outlined under Item (7). Meanwhile, the existing HWVP WSM is being used to predict compliance with WAPS 1.3 based on various tank sampling/analysis strategies and of proposed versions, as they become available, of Items (2), (3), and (4).

6.1.2.4 Remaining Tasks. A computer has been procured for transfer of the DWPF PCCS computer code to HWVP. Completion of the following tasks will be required to close this issue.

- Obtain the PCCS software from DWPF and install this software on an HWVP-designated computer.

- Modify the PCCS simulation program as necessary to model the HWVP process.

- Decide on the final form of the MBM (i.e., measurement error model or Kalman filtering).

- Develop a frit addition algorithm based on correlations available from the QCR study.

- Develop a feed acceptability test algorithm based on correlations available from the QCR study.

- Develop a feed adjustment algorithm based on correlations available from the QCR study. 
- Simulate the degree of compliance with WAPS 1.3 that would be inferred from process data as a function of various tank sampling/ analysis strategies, averaged over a year of process operation.

- Validate the MBM for the SRAT, SME, MFT, and melter.

- Validate a correlation or model of glass cooling history.

- Prepare requirements documentation for implementation of models in the HWVP MIS.

- Support HWVP cold startup and validation and verification of the process models on the HWVP Management Information System (MIS).

6.1.2.5 Schedule Requirements. The schedule assumes that work in progress at the SRS for the PCCS model will be completed in FY 1990 and transfer of an updated code can be achieved in early FY 1991. The milestones listed in Table 6-2 were established for closure of this issue (see Summary Schedule, Figure 11-1, in Section 11.0).

6.1.2.6 Costs. The following cost breakdown was established for this issue (expense dollars in thousands):

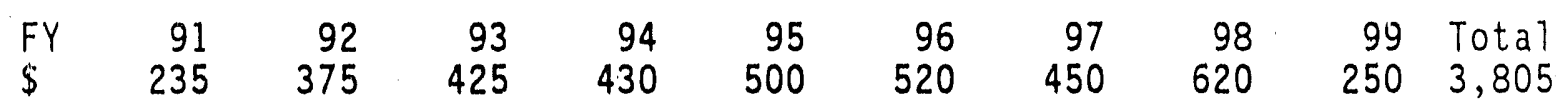

The above costs are based on estimated staff time to provide a level-ofeffort to complete the described work.

\subsection{PRODUCT AND PROCESS TESTING}

The WFQ product and process testing effort is organized into glass properties and TTT diagrams, canistered product qualification, canister drop testing, and radioactive core sample and bench-scale tests. The WFQ product and process testing supplements data obtained from process development tasks for process and product model development. The WFQ radioactive glass durability test results will be used to produce referenceable durability data required by the waste acceptance process.

Product testing will provide durability and physical characterization data of HWVP waste forms. Testing will be conducted with nonradioactive glasses to provide phase behavior and physical properties data required by the WAPS. These test results will be correlated with the durability model and the canister temperature profile measured to obtain cooling history. Principal process technical information needs and the required associated testing are defined in the following task descriptions.

\subsubsection{Glass Properties and Phase Behavior (WBS: 1.2.2.05.03)}

6.2.1.1 Statement of Issue. The WAPS requires that the phase behavior of glasses be reported. To meet this requirement, TTT diagrams must be prepared for glasses within the QCR. Definition of the QCR for the HWVP glasses Will 
WHC-EP-0350

Table 6-2. Process Models Milestone List.

\begin{tabular}{|c|c|c|}
\hline Milestone & $\begin{array}{l}\text { Completion } \\
\text { date } \\
\text { (quarter/FY) }\end{array}$ & Milestone description \\
\hline 1 & 2/1991 & $\begin{array}{l}\text { Provide data sheets for full-scale feed } \\
\text { preparation test plan }\end{array}$ \\
\hline 2 & $2 / 1991$ & Issue report describing MBM \\
\hline 3 & $3 / 1991$ & $\begin{array}{l}\text { Issue report on sampling strategies using } \\
\text { WSM/MBM combination }\end{array}$ \\
\hline 4 & $3 / 1991$ & $\begin{array}{l}\text { Complete evaluation of DWPF PCCS software } \\
\text { and issue plan for process model development }\end{array}$ \\
\hline 5 & $3 / 1992$ & $\begin{array}{l}\text { Complete update of the HWVP mass balance } \\
\text { model based on FY } 1991 \text { LFCM testing }\end{array}$ \\
\hline 6 & $4 / 1992$ & $\begin{array}{l}\text { Demonstrate the preliminary PCCS model for } \\
\text { HWVP including computer graphics }\end{array}$ \\
\hline 7 & $3 / 1993$ & Complete frit addition algorithms \\
\hline 8 & $3 / 1994$ & $\begin{array}{l}\text { Complete feed adjustment and acceptability } \\
\text { algorithm }\end{array}$ \\
\hline 9 & $4 / 1995$ & Complete the PCCS moder \\
\hline 10 & $4 / 1996$ & $\begin{array}{l}\text { Verify and pre-validate all process models } \\
\text { for plant prototypic melter operation }\end{array}$ \\
\hline 11 & $4 / 1996$ & $\begin{array}{l}\text { Complete requirements and logic diagrams for } \\
\text { HWVP MIS programming }\end{array}$ \\
\hline 12 & $4 / 1997$ & $\begin{array}{l}\text { Complete documentation preparation for } \\
\text { integration of all process model software } \\
\text { into the HWVP MIS }\end{array}$ \\
\hline 13 & $4 / 1998$ & $\begin{array}{l}\text { Assist with verification of process model } \\
\text { programming in the HWVP MIS }\end{array}$ \\
\hline 14 & $4 / 1999$ & $\begin{array}{l}\text { Complete validation of process model } \\
\text { software }\end{array}$ \\
\hline
\end{tabular}

be achieved under the Process Development task for Glass Envelope Definition (Section 4.1). Work on the TTT diagrams cannot be initiated unt 11 the QCR has been determined. A statistical approach to composition selection is needed to identify specific compositions to be tested. 
The determination of the TTT diagrams is expected to be the major effort under this issue; however, additional glass properties also are needed to provide input for the canister cooling history correlation. For the most part, this correlation will be based on thermal properties of the glass covering a wide range of compositions within the QCR. The amount of information needed has not been determined but is expected to be defined during the next several years as correlation efforts progress.

6.2.1.2 Scope. Data to be obtained from tests to be conducted for this issue include the following:

- Generation of TTT diagrams for glasses within the QCR to provide the database necessary to meet WAPS requirements for glass crystallinity determination in the canistered waste form

- Measurement of glass thermal and physical properties (density, heat capacity, and thermal conductivity) covering the QCR to provide information needed in correlation of the canister thermal history with TTT diagrams

- Limited testing of glass durability,

6.2.1.3 Status. Limited product crystallinity, heat capacity, density, and thermal conductivity testing to obtain data for incorporation into heat transfer calculations has proceeded for several years under process development and WFQ. Durability, thermal conductivity, and density data were provided for HW39-4 glass for WHC-EP-0008, Hanford Waste Vitrification Plant Preliminary Description of Waste Form and Canister - FY 1988 Update (Mitche11 et a1. 1988).

6.2.1.4 Remaining Tasks. Some product testing cannot be defined until the WAPS for the HWVP is prepared. Based on the DWPF WAPS (DOE-OCRWM 1986), however, the following tasks must be completed before closure of this issue.

- Complete glass TTT testing covering the range of compositions in the glass QCR.

- Complete thermal property measurements of selected glasses in the QCR to provide data for canister cooling history correlation.

- Perform limited durability tests for various crystalline contenis using gTasses from TTT testing to determine effect of crystallinity on durability.

6.2.1.5 Schedule Requirements. The milestones listed in Table 6-3 were established for closure of this issue (see Summary Schedule, Figure 11-1, in Section 11.0).

6.2.1.6 Costs. The following cost breakdown was established for this issue (expense dollars in thousands):
FY
$\begin{array}{rrrr}91 & 92 & 93 & 94 \\ \cdots & 1,000 & 1,140 & 1,190\end{array}$
$\begin{array}{rr}95 & 96 \\ 930 & 280\end{array}$
97
98
99 Total
$85 \quad 80 \quad \ldots \quad 4,705$ 
WHC-EP-0350

Table 6-3. Glass Properties and Phase Behavior Milestone List.

\begin{tabular}{ccl}
\hline Milestone & $\begin{array}{c}\text { Completion } \\
\text { date } \\
\text { (quarter/FY) }\end{array}$ & \multicolumn{1}{c}{ Milestore description } \\
\hline 1 & $2 / 1992$ & $\begin{array}{l}\text { Issue test plan for TTT diagram and thermal } \\
\text { properties determinations } \\
2\end{array}$ \\
$4 / 1992$ & $\begin{array}{l}\text { Complete TTT and associated durability } \\
\text { product testing for QCR }\end{array}$ \\
4 & $4 / 1993$ & $\begin{array}{l}\text { Complete thermal properties testing } \\
\text { Complete glass properties and phase behavior } \\
\text { studies for WFQ } \\
5\end{array}$ \\
$4 / 1994$ & $\begin{array}{l}\text { Provide initial canister cocling history } \\
\text { correlation } \\
\text { Provide input on canister cooling history } \\
\text { correlation to WQR }\end{array}$ \\
\hline
\end{tabular}

TTT = Time-temperature-transformation

These costs are estimates of the staff time needed to complete the required glass formulation and testing and they are loosely based on the QCR study costs that have been planned in detafl. A detalled cost breakdown will be included in the FY 1992 test plan.

\subsubsection{Canistered Product Qualification (WBS: 1.2.2.05.04)}

6.2.2.1 Statement of Issue. Full-size canisters must be filled with glass in order to determine acceptability of the canister weld process because a major consideration for WFQ is that the canister pass the drop test after welding. Data are also needed from the full-size canisters to evaluate the canister cooling history and the mass balance and PCCS models. These data will be obtained by sectioning the canisters and removing glass samples at different radial and longitudinal positions for composition analyses, durability assessment, and phase determinations. Thorough evaluation of the canisters produced during melter runs using simulant feed composition corresponding to the various HWVP feeds (i.e., NCAW, NCRW, and CC and PFP waste) will be needed to show compliance with WFQ durability requirements and to confirm the cooling history correlation. Canister(s) must be instrumented with thermocouples to provide temperaturo gradient data for correlation of the canister cooling history with TTT diagrams.

Initial canister evaluations will be needed during FYs 1992 to 1994 to vertfy process models using LFCM run data. From FYs 1994 to 1998, testing of canisters produced during operation of the plant prototypic melter will be needed to provide data for model pre-validation before model utilization in the HWVP MIS. Evaluation of the canister/glass interaction at various locations also is required to verify compliance with the WAPS. 
6.2.2.2 Scope. The scope of the effort to be conducted under this issue includes the following work:

- Preparation of QA documentation necessary for fabrication and procurement of full-size HWVP canisters, and subsequent flliting of canisters with glass

- Sectioning of cantsters filled with glass and removal of glass samples

- Measurement of composition, durability, and phases present in glass samples

- Instrumentation of canisters to obtain temperature data during glass filling and cooling for canister thermal history correlation

- Measurements of the interaction of glass with the canister to assume chemical compatibility.

6.2.2.3 Status. Work has not been initiated by HWVP on this task. The QA procedures for canister fabrication have been prepared by DWPF staff and efforts will be made to obtain this information during FY 1991. Canisters have been sectioned at SRS and discussions will be held with responsible SRS staff to determine if these data are pertinent to HWVP.

6.2.2.4 Remaining Tasks. Testing required on the canister cannot be completely defined until the HWVP WAPS is issued. The following tasks have been identified to close this issue.

- Procure and fill canisters for weld qualification and drop testing.

- Determine uniformity of the glass composition, range in glass durability, and phase behavior for canisters filled with glass representing each waste type and filled at pouring rates that cover the range allowed for plant operations.

- Establish the degree of interaction between the canister and the glass representing each waste type for the range of temperatures to be encountered during melter pouring.

- Establish the canister and glass temperature profiles that can be expected during pouring by monitoring the temperature at different radial and longitudinal locations.

- Correlate data obtained from the above testing with process/product models and glass properties measurements.

6.2.2.5 Schedule Requirements. The milestones 1 isted in Table 6-4 were established for closure of this issue (see Summary Schedule, Figure 11-1, Section 11.0). 
WHC-EP-0350

Table 6-4. Canistered Product Qualification Milestone List.

\begin{tabular}{|c|c|c|}
\hline Milestone & $\begin{array}{l}\text { Completion } \\
\text { date } \\
\text { (quarter } / F Y \text { ) }\end{array}$ & Milestone description \\
\hline 1 & $2 / 1992$ & $\begin{array}{l}\text { Issue test plan for cantstered product } \\
\text { evaluation }\end{array}$ \\
\hline 2 & $3 / 1992$ & $\begin{array}{l}\text { Procure canisters and fill with glass for } \\
\text { weld qualification and drop testing }\end{array}$ \\
\hline 3 & $4 / 1993$ & $\begin{array}{l}\text { Prepare full-size canisters filled with } \\
\text { glass, section canisters, and evaluate glass } \\
\text { for crystalline phases, composition } \\
\text { uniformity, and durability }\end{array}$ \\
\hline 4 & 4,1995 & $\begin{array}{l}\text { Complete measurements of cantster glass } \\
\text { thermal proftles }\end{array}$ \\
\hline 5 & $4 / 1996$ & $\begin{array}{l}\text { Establish degree of interaction between } \\
\text { canister and glasses within the QCR waste } \\
\text { type }\end{array}$ \\
\hline 6 & $4 / 1997$ & $\begin{array}{l}\text { Complete canistered product evaluation for } \\
\text { pre-validation of mass balance and PCCS } \\
\text { models, and cantster cooling history } \\
\text { correlation }\end{array}$ \\
\hline 7 & $4 / 1998$ & $\begin{array}{l}\text { Complete correlations of cantstered waste } \\
\text { form composition profile with product and } \\
\text { process model predictions }\end{array}$ \\
\hline
\end{tabular}

6.2.2.6 Costs. The following cost breakdown was established for this issue (expense dollars in thousands):

$\begin{array}{lrrrrrrrrrr}F Y & 91 & 92 & 93 & 94 & 95 & 96 & 97 & 98 & 99 & \text { Total } \\ \$ & -- & 450 & 655 & 600 & 650 & 680 & 725 & 660 & - & 4,420\end{array}$

The estimated costs include procurement of canisters, tooling needed to sectiun canisters, staff time required to ensure proper filling with glass and handling, and analytical support for glass sample evaluation.

\subsubsection{Cantster Drop Testing (WBS: 1.2.2.05.05)}

6.2.3.1 statement of Issue. The DWPF WAPS (DOE-OCRWM 1986) that is being used by the HWVP Project as a guideline requires that the canistered waste form at time of shipment be capable of withstanding a drop of $7 \mathrm{~m}(23 \mathrm{ft})$ onto a flat, essentially unytelding surface without breaching. The producer shall describe the method of compltance in the WCP and present the supporting documentation of analysis and test results in the WQR. The test results shall 
include information on measured cantster leak rates and canister deformation after the drop test. For HWVP, an analysis will be needed to determine the maximum drop distance for a canister and position/surface to be evaluated based on the detafled design of the plant. This result will be compared to the WAPS requirement and test conditions will be spectfied.

Drop test verification datia are required for cantstars from each waste producer. The fllled HWVP canisters will be simflar in design and content to the DWPF canisters; however, GTAW of the canister lid (similar to the WVDP process) will be used for final canister closure. Because the closure welding will be different from the DWPF upset resistance welding, addittonal drop testing is expected to be needed to support weld development and closure qualification. Development drop testing will be needed to evaluate different litd and seal weld concepts and key design parameters that are important to maintaining canister integrity during impact and deformation. Weld qualifica. tion will determine the limits of weld penetration that are acceptable for closure and drop test compliance.

6.2.3.2 Scope. The scope of testing will include procurement of full-size HWVP canisters, conducting QA inspections, and filling the cantsters with glass in a manner similar to that to be used for obtaining glass-filled canisters for evaluation of canistered product and thermal modeling. The canisters will then be temporarily sealed with an inner cantster closure plug. This plug will be subsequently forced into the canister and the 1 id will be inserted for final closure using GTAW equipment similar to the equipment planned for HWVP (see Section 5.2). The canisters will be dropped onto an unyielding surface in three orientations (bottom, side, and head at an angle). The dropped canisters will be checked for leak tightness, distortion, and integrity, and these results will be documented. Further evaluation will consist of sectioning the canisters around the impact zone and at other locations to evaluate the damage to the weld metal and to examine the glass integrity (cracking surface area increase). The cantster's will be filled with glass during the FY 1992 LFCM tests.

6.2.3.3 Status. Canister drop testing has been performed at the SRS for DWPF and at the WWDP as part of its respective WCP efforts to demonstrate compliance with the WAPS. No drop testing has been performed for any HWVP glass-filled full-size canisters.

6.2.3.4 Remaining Tasks. The entire scope of work remains to be performed. Various tasks that must be completed to close this issue are as follows.

- Procure ful1-size HWVP canisters with a neck design that is consistent with lid closure configuration and conduct $Q A$ inspections.

- Prepare a test plan for cantster glass filling, closure welding, and drop testing.

- Prepare a canister drop test pad and drop canisters in three configurations.

- Examine dropped canisters for distortion, leak tightness, and weld integrity. 
- Section selected canlsters around the impact zone and at other locations to examine weld integrity and damage to the glass (breakage).

6.2.3.5 Schedule Requirements. The milestones 1 isted in Table 6-5 were established for closure of this issue (see Summary Schedule, Figure 11-1, Section 11.0).

6.2.3.6 Costs. The following cost breakdown was established for this issue (expense dollars in thousands).

$\begin{array}{lrrrrrrrrrr}\text { FY } & 91 & 92 & 93 & 94 & 95 & 96 & 97 & 98 & 99 & \text { Total } \\ \$ & \ldots & 480 & 300 & \ldots & \ldots & \ldots & \ldots & \ldots & \ldots & 780\end{array}$

Costs for drop testing were estimated from previous costs incurred by DWPF for similar testing.

\subsubsection{Radioactive Process/Product Laboratory Tests}

(WBS: 1.2 .2 .05 .06 )

6.2.4.1 Statement of Issue. The WFQ radloactive product testing is needed to provide data that can be correlated to results obtained from nonradloactive product testing for WFQ product modeling. Also, process information pertaining to formic acid addition requirements will be provided. Product models are being developed on the basis of nonradioactive product test results. Additionally, durability and physical property data from radioactive testing will be used directly as inputs to the WQR and repository 1 icensing database. Data will be developed from pretreated DST core samples taken from NCAW, NCRW, and CC and PFP wastes, samples from pretreatment pllot plant tests, and samples from pretreated waste tanks.

These tests will address the technical correlation of radloactive process data to the larger body of nonradioactive data generated in this Plan. Laboratory-scale process test data w111 be used to confirm chemical and physical similarities in vitrifying radioactive materiai when compared to

Table 6-5. Canister Drop Testing Milestone List.

\begin{tabular}{ccl}
\hline Milestone & $\begin{array}{c}\text { Completion } \\
\text { date } \\
\text { (quarter/FY) }\end{array}$ & \multicolumn{1}{c}{ Milestone description } \\
\hline 1 & $2 / 1992$ & Issue test plan for cantster drop testing \\
2 & $4 / 1992$ & $\begin{array}{l}\text { Obtain full-size HWV cantsters, conduct QA } \\
\text { inspection, fill with glass, and weld }\end{array}$ \\
3 & $2 / 1993$ & Complete canister drop tests \\
4 & $4 / 1993$ & Issue a cantster drop test report \\
\hline
\end{tabular}

$Q A=$ Qualtty assurance 
nonradioactive simulants. The data of interest include, but are not 1 imfted to, slurry phystcal and rheological properties, glass physical properties, reduction/ oxtdation state of the glass, and chemical composition of the slurries and glass.

6.2.4.2. Scope. The following process testing will be conducted on pretreated NCAW, NCRW, CC, and PFP slurries:

- HWVP feed concentration, formic acid reaction, and characterization

- Melter feed makeup and characterization

- Melter feed vitrification and characterization

- Glass durability measurement using MCC-1 and product consistency tests

- Elemental chemical analyses

- Isotopic analyses.

6.2.4.3 Status. In FY 1990, two NCAW core samples from DS"r 101 -AZ were pretreated and characterized. Each washed core sample was reacted with formic actd and blended with frit to prepare melter feed. The formated waste and melter feeds were charactertzed. Each of the two melter feeds was vitifified; the resulting glass will be characterized for durability, density, and composition in FY 1991. Planning for addittonal core sample evaluation is being prepared by Westinghouse Hanford. Numerous DST core samples will be obtained in FYs 1991 to 1994, and efforts will be made to convert many of these samples (after pretreatment) into radloactive glass for WFQ testing. Work conducted under this issue must be closely coordinated with the WMD activities to obtain data from core samples for pretreatment flowsheet evaluation.

6.2.4.4 Remaining Tasks. Completion of the following tasks will close this issue.

- Prepare glasses from NCAW core samples and obtain durability and phystcal property data.

- Complete testing and characterization (composition, durablitty and phase content) of glass produced from NCAW, NCRW, CC, and PFP core samples.

6.2.4.5 Schedula Requirements. The milestones 11sted in Table 6-6 were established for closure of this is sue (see Summary Schedule, Figure 11-1, in Section 11.0). The vitriflcation test milestones can be met only if the WMD provides the sample in a timely manner. 
WHC-EP-0350

Table 6-6. Radioactive Process/Product Laboratory Tests Milestone List.

\begin{tabular}{|c|c|c|}
\hline Milestane & $\begin{array}{c}\text { Completion } \\
\text { date } \\
\text { (quarter/FY) }\end{array}$ & Milestone description \\
\hline 1 & $4 / 1991$ & $\begin{array}{l}\text { Complete characterization of } 3 \text { radioactive } \\
\text { NCAW core sample glasses without cestum or } \\
\text { TRU recycle }\end{array}$ \\
\hline 2 & $4 / 1992$ & $\begin{array}{l}\text { Vitrify three additional core samples to be } \\
\text { designated. Characterize and test resulting } \\
\text { glass }\end{array}$ \\
\hline 3 & $4 / 1993$ & $\begin{array}{l}\text { Vitrify four additional core samples to be } \\
\text { designated. Characterize and test resulting } \\
\text { glass }\end{array}$ \\
\hline 4 & $4 / 1994$ & $\begin{array}{l}\text { Vitrify additional core samples and } \\
\text { laboratory oxide sample(s) from pretreatment } \\
\text { pllot plant tests. Number and waste type of } \\
\text { core samples will be designated. } \\
\text { Characterize and test resulting glass }\end{array}$ \\
\hline 5 & $4 / 1995$ & Same as Milestone 4 \\
\hline 6 & $4 / 1996$ & Same as Milestone 4 \\
\hline 7 & $4 / 1998$ & $\begin{array}{l}\text { Vitrify sample(s) from pretreated NCAW tank. } \\
\text { Characterize and test resulting glass }\end{array}$ \\
\hline
\end{tabular}

6.2.4.6 Costs. The following cost breakdown was established for this issue (expense dollars in thousands):

$\begin{array}{lrrrrrrrrrr}\text { FY } & 91 & 92 & 93 & 94 & 95 & 96 & 97 & 98 & 99 & \text { Total } \\ \$ & 700 & 1,300 & 1,150 & 1,200 & 1,500 & 440 & 425 & 340 & 250 & 7,305\end{array}$

Costs for this task were estimated from costs for core sample processing and vitrification established in FY 1990. Adjustments to these costs are contemplated based on avallability of core samples for process/product testing.

\subsubsection{Radfoactive Bench-Scale Tests (WBS: 1.2.2.05.07)}

6.2.5.1 Statement of Issue. Bench-scale testing of each of the radtoactive waste feeds for HWVP is necessary to ensure there are no unanticipated differences in behavior assoctated with processing radioactive waste in a melter compared to results obtained on simulant feeds. In addition, radioactive bench-scale tests are needed to provide actual glass prepared by processing the waste through a slurry-fed glass melter. The quality of this glass must be compared to radioactive glass made from waste tank core samples 
and glasses prepared from simulant feed to vertfy the performance characteristics of glass of the same composition in the QCR. Comparison of stmulant and radioact tve feed process behavior and simulant and radioactive glasses will provide assurance that the synthetic nonradioactive feeds used for process development will behave the same as actual radioact tve waste.

Planning calls for performing equipment operabllity tests and cold runs of the bench-scale radioactlve process test equipment before transfer of tints equipment to a hot cell. The bench-scale cold-run tests will provide baseline equipment performance data (bot1-off rate, DFs, etc.). These equipment performance data can then be compared directly to radioactive bench-scale test data to identify the impact of feed differences. The feed difference comparison can then be used for semiquantitative impact evaluation of results obtained from nonradioactive full-scale equipment tests. These impact evaluations must be made through correlations to cold-run bench-scale data. Testing will be performed using radioactive waste obtained from pretreated NCAW, NCRW, and PFP and CC Wastes. These tests are needed to provide the final technical confirmation that the larger body of nonradioactive data generated in this plan is applicable for plant design and there are no unanticipated differences that must be resolved before hot startup. It is recognized that there is no way to ensure that every possible aspect of process behavior has been anticipated; however, these bench-scale melter tests should minimize risks for processing each waste type in HWVP.

In order to provide data for comparison of simulant with radioactive feeds, the melter and support equipment for the radioactive tests will require operation with simulant feeds before installation in the hot cell. Information of interest includes, but is not limited to, confirming pretreated feed melter processing behavior for each HWVP feed type, correlating actual feed/ glass properties with simulant data, and preparing sufficient quantities of melter-processed radioactive glass to accomplish the following.

- Determine the behavior of ruthentum phase formation (needle-like or globular) in vitrifying actual NCAW for correlation with data obtained from simulant feed noble metals testing (Section 5.5.1).

- Verify waste radionuclides to be reported in the WQR.

- Obtain a waste form crystallinity/durability statistical database for the WQR.

- Provide confirmation of specific semivolatile radionuclide feed component decontamination factors used in HWVP Clean Air Act (CAA 1977) permitting.

A plan must be prepared to determine how data from CC, PFP, and NCRW pretreated radioactive feeds that will be bench-scale tested after FY 1996 will be compared to the data obtained from cold runs that w111 need to be performed at an early date.

6.2.5.2 Scope. The scope of this issue will ilulude the following work phases.

- Construct a berich-scale test equipment system for hot cell testing. 
- Provide support equipment and facilities for acceptance check-out of the bench-scale equipment before installation in a hot cell.

- Conduct bench-scale nonradioactive tests with simulants of all waste types to be tested to provide data for performance bench-mark out of cell.

- Install bench-scale equipment in the 324 Building hot cell.

- Receive radioactive sludge in shipping containers and transfer it to the bench-scale feed concentration vessel for processing.

- Conduct bench-scale radioactive tests of each major HWVP feed type in a hot cell and obtain composition and operational data for performance assessment.

- Evaluate giass properties and durability and correlate data with nonradioactive tests.

6.2.5.3 Status. The bench-scale testing equipment was designed in FY 1990 . Plans are to use a joule-heated 1/50-scale melter for process testing. The NCAW bench-scale tests were to be conducted in FY 1994. However, a delay of approximately 1 year in the radioactive testing of pretreated NCAW is anticipated due to funding constraints in FY 1991. Because of the delay, pretreated NCRW may become available before NCAW. Bench-scale test planning will be developed such that the tests will start with the waste that becomes available first.

Current plans are to install equipment to be used for radioactive benchscale testing in the 324 Building B cell. Cleanout of existing equipment is in progress through funding under another DOE program. The schedule for $B$ cel1 cleanout is righly dependent on this funding support, which is uncertain at this time. A request is being submitted to DOE to provide funding for $B$ cell cleanout under the HWVP Project.

6.2.5.4 Remaining Tasks. Radioactive melter testing can occur when representative feed material is available and after the reference vitrification process parameters and QCR have been established using simulated HWVP feeds. Completion of the following tasks will be required to close this issue.

- Prepare the facilities and necessary documentation for receiving and removing sludge from the shipping container.

- Provide sufficient hot cell space to accommodate the HWV benchscale equipment. A cost-benefit analys is should be performed to determine the optimum hot cell space for the bench-scale tests. (This is not identified as an HWVP-furded activity.)

- Design, construct, and test bench-scale melter equipment before installation in a hot cell.

- Conduct a readiness review of the 324 Building hot cell facilities for slurry receipt and melter testing.

- Prepare a test plan fulfilling the otjectives of section 6.2.5.2. 
- Receive a shipping cask and transfer each of the feed slurry types to the 324 Building for testing [approximately 140 to $200 \mathrm{~kg}$ (208 to $440 \mathrm{lb}$ ) of waste oxides].

- Conduct bench-scale radioactive melter testing (approximately 10 days of operation) for each HWVP waste type.

- Analyze slurries, offgas solutions and particulates, and glass to establish mass bal ance and melter DFs.

- Evaluate the composition and durability of radioactive glass obtained from processing through a slurry-fed melter.

- Compare data obtained from radioactive bench-scale testing to data from nonradioactive tests including chemical behavior of noble metal phases in NCAW.

6.2.5.5 Schedule Requirements. The schedule presumes the use of the PNL B Ceil facility. If this facility is not available, the approach will be revised. The schedule also is based on initiation of activities to support shipping cask selection and $B$ Plant readiress in FY 1992 and having pretreated feed available for shipment in early FY 1994. The milestones listed in Table 6-7 were established for closure of this issue (see Summary Schedule, Figure i1-1, in Section 11.0).

6.2.5.6 Costs. The following cost breakdown was established for this issue (dollars in thousands):

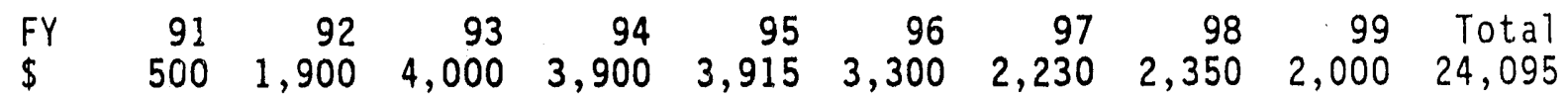

The above costs are based on a detailed cost breakdown for bench-scale testing provided in FY 1990. Further refinement of the cost breakdown is planned.

Table 6-7. Radioactive Bench-Scale Tests Milestone List. (sheet 1 of 2 )

\begin{tabular}{ccl}
\hline Milestone & $\begin{array}{c}\text { Completion } \\
\text { date } \\
\text { (quarter/Fy) }\end{array}$ & \multicolumn{1}{c}{ Milestone description } \\
\hline 1 & $1 / 1991$ & Issue plan for radioactive process tests \\
2 & $4 / 1991$ & $\begin{array}{l}\text { Procure glass melter and other long-lead } \\
\text { equipment for bench-scale radioactive } \\
\text { testing }\end{array}$ \\
3 & $2 / 1992$ & $\begin{array}{l}\text { Procure remaining bench-scale radioactive } \\
\text { testing equipment } \\
\text { Complete bench-scale process equipment } \\
\text { fabrication }\end{array}$ \\
\hline
\end{tabular}


Table 6-7. Radioactive Be-ch-Scale Tests Milestone List. (sheei 2 of 2 )

\begin{tabular}{|c|c|c|}
\hline Milestone & $\begin{array}{l}\text { Completion } \\
\text { date } \\
\text { (quarter/FY) }\end{array}$ & Milestone description \\
\hline 5 & $3 / 1993$ & Issue simulant feed bench-scale test plan \\
\hline 6 & $1 / 1994$ & $\begin{array}{l}\text { Complete bench-scale equipment check-out and } \\
\text { cold runs using simulant NCAW, NCRW, CC and } \\
\text { PFP }\end{array}$ \\
\hline 7 & $4 / 1994$ & $\begin{array}{l}\text { Install bench-scale process equipment in the } \\
324 \text { Building hot cell }\end{array}$ \\
\hline 8 & $1 / 1995$ & Issue radioactive bench-scale test plan \\
\hline 9 & $4 / 1995^{*}$ & $\begin{array}{l}\text { Complete radioactive bench-scale NCAW } \\
\text { process test }\end{array}$ \\
\hline 10 & $4 / 1996$ & $\begin{array}{l}\text { Evaluate radioactive glass from NCAW process } \\
\text { cest and compare results with nonradioactive } \\
\text { test data }\end{array}$ \\
\hline 11 & $1 / 1997^{*}$ & $\begin{array}{l}\text { Complete radioactive bench-scale NCRW } \\
\text { process test }\end{array}$ \\
\hline 12 & $4 / 1997$ & $\begin{array}{l}\text { Complete radioactive bench-scale PFP process } \\
\text { test }\end{array}$ \\
\hline 13 & $1 / 1998$ & $\begin{array}{l}\text { Evaluate radioactive glass from NCRW process } \\
\text { test }\end{array}$ \\
\hline 14 & $4 / 1998$ & $\begin{array}{l}\text { Evaluate radioactive glass from PFP process } \\
\text { test }\end{array}$ \\
\hline 15 & $4 / 1998$ & $\begin{array}{l}\text { Complete radioactive bench-scale CC process } \\
\text { test }\end{array}$ \\
\hline 16 & $4 / 1999$ & $\begin{array}{l}\text { Evaluate radioactive glass from } C C \text { process } \\
\text { test }\end{array}$ \\
\hline
\end{tabular}

*NCAW and NCRW tests are interchangeable based on availability of radioactive waste feeds. 
WHC-EP-0350

\subsection{PLANT EQUIPMENT DEVELOPMENT - WESTINGHOUSE HANFORD}

(WBS: 1.2 .3 .01 )

Some equipment to be installed in the HWVP will require adaptation of existing technology to a new application by Westinghouse Hanford. In many cases, this transition can be made with minimal evaluation and testing. This task covers specific items of equipment that have been identified as needing further verification testing and/or interface control to ensure functional compliance and reliability.

In FY 1988, the HWVP Analytical Laboratory computer system functional requirements for sample vial readability and traceability in a hot cell, including elimination of human error, were evaluated and documented. Studies in FYs 1989 and 1990 have shown the use of bar codes for sample vial identification and tracking throughout the HWVP Analytical Laboratory will meet system functional requirements. Bar codes are the system of choice for future application in the Hanford Site analytical laboratories as we11. Because HWVP requires stringent sampling and numerous analyses for process control and because the plant must rely on other site laboratories for support, bar code use is a major goal for the HWVP. The system adapted for the HWVP is expected to be suitable for use at the other DOE site laboratories.

\subsection{ANALYTICAL LABORATORY SAMPLE TRACKING SYSTEM (WBS: 1.2 .3 .01 .04 )}

\subsubsection{Statement of Issue}

The HWVP Analytical Laboratory will analyze both numerous radioactive samples taken from processing vessels within the canyon and nonradioactive samples from chemical make-up tanks and various required monitoring locations throughout the plant. A system is needed for labeling the sample vials and tracking the samples through different stages of dilution and analysis. Requirements for sample labeling and tracking, including the computer system to be used throughout the Analytical Laboratory, have been defined. Further work is needed to develop bar code readers that can withstand exposure to high-radiation levels and that will interface with the computer system to be used for tracking the samples and reporting analyses results. The readers used in the high-radiation zone must be compatible with hand-held readers that are available for normal chemical analyses hood operations. Space within the analytical cells must be kept free of obstructions to allow maximum reach of the master-slave manipulators. Any equipment placed within the analytical cell must be easily replaceable in case of failure.

\subsubsection{Scope}

This work includes development of the sample labels, bar code readers, and computer interface to be used within the high-radiation cells in the Analytical Laboratory. The system must be tested to show electronic 
compatibility and rellability. Requirements for the equipment to be used inside and outside the analytical cell and impacts on desigr inust be clearly defined.

\subsubsection{Status}

Work in FY 1989 showed that there is no existing capability for bar code reading in a high-radiation area at other sites in this country or abroad. Considerable progress has been made regarding evaluation of avallable technology for this application. A study was completed in FY 1989 to determine the overall feasibility of successfully meeting the requirements for a sample tracking system that predicted a high probability of favorable outcome. A system was selected that uses an in-cell camera in conjunction with an out-of-cell television screen with special electronics to convert the bar code image to a digital electronic signal. Equipment for concept testing and qualification was purchased in FY 1990 and is being evaluated. Bar code labels have been tested under radiation and numerous options are avallable for hot cell implementation.

\subsubsection{Remaining Tasks}

Completion of the following tasks will close this issue.

- Conduct testing of candidate hardware and support equipment to demonstrate concept functionality. Perform qualification testing to verify system reliability.

- Transfer sample tracking system to Fluor.

\subsubsection{Schedule Requirements}

This issue must be closed by the end of FY 1991 to support detalled design of the Analytical Laboratory. The milestones 11sted in Table 7-1 were established for closure of this issue (see Summary Schedule, Figure 11-1, in Section 11.0).

\section{1 .6 Costs}

The following cost breakdown was established for completion of this issue (expense dollars in thousands).

$\begin{array}{lrrrrrrrrrr}\text { FY } & 91 & 92 & 93 & 94 & 95 & 96 & 97 & 98 & 99 & \text { Total } \\ \$ & 110 & 50 & -\ldots & \ldots & -- & -- & \ldots & \ldots & \ldots & 160\end{array}$

This cost was prepared from a detailed cost breakdown for efforts to complete work initiated in FYs 1990 to 1991. 
Table 7-1. Analytical Laboratory Sample Tracking System Milestone List.

\begin{tabular}{ccc}
\hline Mifestone & $\begin{array}{c}\text { Completion } \\
\text { date } \\
\text { (quarter/FY) }\end{array}$ & Milestone description \\
\hline 1 & $4 / 1991$ & $\begin{array}{l}\text { Complete anilytical sample tracking system } \\
\text { reliability tests and issue recommendation } \\
\text { report for Detailed Design }\end{array}$ \\
2 & $4 / 1992$ & $\begin{array}{l}\text { Complete transfer of analytical sample } \\
\text { tracking system to Fluor }\end{array}$ \\
\hline
\end{tabular}




\subsection{PROCESS TESTING - WESTINGHOUSE HANFORD \\ (WBS: $1.2 .3 .01 / 1.2 .3 .03 / 1.2 .5 .03$ )}

A 1 imited amount of process testing is antfcipated to support radtoactive waste shipments to the 300 Area for bench-scale testing, for frit vendor qualification, and as backup to a melter performance assessment in cooperation with the SRS. The types of activities that could be conducted under this task include shipping cask evaluation and preparation for radtoactlve waste shipments, frit procurement and evaluation, and cooperative melter tests that are designed to provide data of interest to HWVP and the performing organization.

Because sensitivities extst regarding impacts on scheduled work at the SRS, testing wiil be dependent on avallability of supporting staff and equipment for this purpose. Westinghouse Hanforc budget constratnts during FYs 1990 and 1991 have focused attention on FY 1992 for continuation of negotiations to conduct tests at the SRS.

\subsection{RADIOACTIVE WASTE SHIPMENT SUPPORT (WBS: 1.2 .5 .03 .02 )}

\subsubsection{Statement of Issue}

The HWVP radioactive tests (1aboratory- and bench-scale) wi11 requite pretreated NCAW, NCRW, PFP and CC to be used as feed. The raw wastes are stored in the Hanford 200 East Area. For bench-scale testing, large amounts of these wastes must be pretreated and shipped to the 324 Butiding in the 300 Area where the tests will be conducted. For each of the waste types, a smal1 sample [approximately $200 \mathrm{~g}(0.44 \mathrm{lb})$ of oxides] and a large shipment [150 to $200 \mathrm{~kg}$ ( 330 to 440 lb) of oxides] are requitred. The small sample is needed to ensure the waste in the large shipment is sultable for vitrification.

Shipping pretreated wastes involves activities to address technical, administrative, and regulatory issues in three areas: (1) selection of a shipping cask, (2) preparations at the sending and receiving factlities, and (3) the actual transport of the waste. The support activities will focus on shipping NCAW because this waste has the highest heat load and dose rate of a 11 HWVP feeds. It is expected that the capabilities established for NCAW will encompass requirements for shipping the other wastes.

\subsubsection{Scope}

This task will establish the capabilities for shipping wastes from the 200 Area to the 324 Butlding to provide feeds for the HWVP radtoactive bench. scale i.:s. More specifically, the task will address the technical, admints. trative, and regulatory issues regarding the shipment of radioactive wastes. 
WHC - EP- 0350

\section{1 .3 status}

A plan covering the shipment of NCAW has been developed. Implementation of this plan will establish the capabilities for shipping NCAW solids from B Plant in the 200 Area to the 324: Bullding and provide feed for the NCRW. bench-scale tests that are planned for FY 1995. The WMD has recently provided information for the pretreatinent development and demonstration that changes the timing for bench-scale testing to the following schedule: NCRW tests in FY 1995, NCAW tests in FY 1996, PFP tests in FY 1997, and CC tests in FY 1998.

\subsubsection{Remaining Tasks}

The following activities are necessary to complete the task of providing feeds for the HWVP bench-scale tests.

- Update the NCAW shipping plan to include NCRW, PFP, and CC shipments.

- Implaient this plan.

- Select a shipping cask and complete all administrative and regulatory documentation.

- Ship waste to the 324 Butlding.

\subsubsection{Schedule Requirements} issue.

The milestones 1isted in Table 8-1 were established for closure of this

\section{1 .6 Costs}

The following funding requirements, which do not include funding by the Westinghouse Hanford WMD to support this task, were established for closure of this issue (expense dollars in thousands):

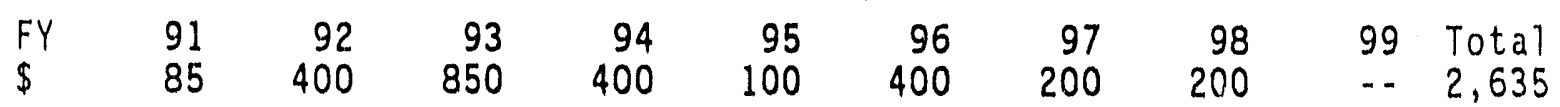

These costs were established by detafled planning in FY 1990 for all HWVP activities needed to support the WMD work that must be completed to provide the quantity of waste required for testing. Costs for WMD work are under another program covering pretreatment development.

\subsection{FRIT VENDOR QUALIFICATION (WBS: 1.2 .3 .03 .01 )}

\subsubsection{Statement of Issue}

Melter testing to be initiated in FY 1994 using the plant prototypic melter will provide data for WFQ process and product model verification and 
Table 8-1. Radioactive Waste Shipment Support Milestone List.

\begin{tabular}{|c|c|c|}
\hline Mtlestone & $\begin{array}{l}\text { Completion } \\
\text { date } \\
\text { (quarter/Fy) }\end{array}$ & Mllestorie description \\
\hline 1 & $4 / 1991$ & $\begin{array}{l}\text { Update NCAW shipping plan to include NCRW, } \\
\text { PFP, and CC shipments }\end{array}$ \\
\hline 2 & $2 / 1993$ & Complete update of the shipping plan \\
\hline 3 & $2 / 1994$ & $\begin{array}{l}\text { Complete activities for the selection of a } \\
\text { shipping cask, including proviston of } \\
\text { regulatory and administrative documentation } \\
\text { for transporting radioactive waste }\end{array}$ \\
\hline 4 & $2 / 1994$ & $\begin{array}{l}\text { Evaluate preparations in the } 324 \text { Bullding } \\
\text { for recelving the radioactive waste shipping } \\
\text { cask }\end{array}$ \\
\hline 5 & $4 / 1994$ & Complete shipment of NCRW sollds* \\
\hline 6 & $4 / 1994$ & Complete update of the shipping plan \\
\hline 7 & $4 / 1995$ & Complete update of the shipping plan \\
\hline 8 & $1 / 1996$ & Complete shipment of NCAW solids* \\
\hline 9 & $4 / 1996$ & Complete the shipment of PFP \\
\hline 10 & $4 / 1996$ & Complete update of the shipping plan \\
\hline 11 & $4 / 1997$ & Complete the shipment of $C C$ \\
\hline
\end{tabular}

* Schedules for NCRW and NCAW are interchangeable based on avallabllity of the wastes.

pre-validation. Testing conducted under strict QA requirements will continue for several years. For these data to be of sufficient quality for prevalidation of the process and product models, the frit must meet requirements imposed for plant operations.

Testing must be conducted using a frit procured from a qualified vendor with analytical overcheck at Hanford to verify composition. Capabilities for frit composition overcheck to the highest possible analy'tical standards also must be provided at Hanford for HWVP cold-run testing in subsequent years prior to hot startup. Work at SRS has shown that considerable effort will be needed to obtain analytical capabllitiles that can be of suffictent preciston and accuracy to be acceptable for plant operation. Vendor qualification will be needed to ensure that QA capabilities are suffictent for production to meet stringent standards. 


\subsubsection{Scope}

This task will include efforts to upgrade extsting PNL and Westinghouse Hanford analytical capabllities to be suffictent for verification of the frit composition to be used for process testing, HWVP cold runs, and HWVP operation including establishing qualified vendors for frit procurement. A vendor qualification program simllar to the SRS program will be inttlated to establish a qualifled source of frit consistent with plant operatior and QA requirements. Work in progress at the SRS is an important database that will be used to minimize the effort required for frit procurement at Hanford.

\subsubsection{Status}

Work concerning this issue has not been inttlated at Hanford. Work at the SRS is being monttored and will be used to establish similar capabiltty at Hanford to meet testing requirements.

\subsubsection{Remaining Tasks}

Completion of the following tasks will close this issue.

- Prepare a plan for frit vendor qualification based on SRS expertence.

- Obtain frit samples from SRS for evaluation of Hanford analytical capability.

- Upgrade PNL and Westinghouse Hanford analytical capabtlittes for frit composition analysis as required.

- Conduct a frit vendor qualification program to establish sources for frit procurement at Hanford.

- Procure frit for plant prototypic melter testing.

\subsubsection{Schedule Requitrements}

Further planning will be needed to establish a schedule for this work. The milestones 1isted in Table 8-2 were established for closure of this issue (see Summary Schedule, Figure 11-1, in Section 11.0).

\section{2 .6 Costs}

The following cost breakdown was established for this issue (expense dollars in thousands):

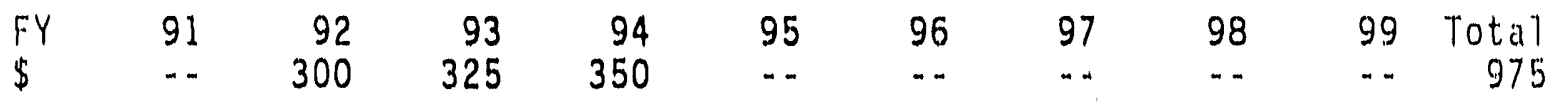


Table 8-2. Frit Vendor Qualffication Mllestone List.

\begin{tabular}{|c|c|c|}
\hline M+lestone & $\begin{array}{l}\text { Completion } \\
\text { date } \\
\text { (quarter/FY) }\end{array}$ & Mtlestone description \\
\hline 1 & $2 / 1992$ & $\begin{array}{l}\text { Complete plan for frit vendor qualiftcation } \\
\text { and Hanford analytical factlity upgrade }\end{array}$ \\
\hline 2 & $4 / 1992$ & $\begin{array}{l}\text { Issue frit spectfication for vendor bidding } \\
\text { and frit procurement }\end{array}$ \\
\hline 3 & $4 / 1993$ & $\begin{array}{l}\text { Complete upgrade of Hanford analytical } \\
\text { capabilitties and evaluate vendo - submitted } \\
\text { frit }\end{array}$ \\
\hline 4 & $4 / 1994$ & $\begin{array}{l}\text { Complete vendor qualiftcation and procure } \\
\text { qualifled frit for plant prototyptc melter } \\
\text { run }\end{array}$ \\
\hline
\end{tabular}

The projected costs are based on an estrmate for the total effort spread equally throughout a 3-year pertod. More detalled planning is anticipated in FY 1991.

\subsection{PROCESS TESTING IN THE INTEGRATED DEFENSE WASTE PROCESSING FACILITY MELTER SYSTEM (SAVANNAH RIVER SITE) (WBS: 1.2 .3 .01 .01 )}

\subsubsection{Statement of Issue}

Work descrtbed under the Process Development and Verification Testing and Equipment Adaptation sections has been scheduled to assess HWVP melter performance with feeds containing high chlortdes, mercury, cadmlum, urantum, and noble metals. This task provides a contingency plan in case difficultites are encountered with planned activities and work cannot be conducted on a timely basis. The plan calls for additional utilization of TNX factlittes avallable at the SRS to conduct tests in the IDMS that has a $1 / 5-5 c a l e$ feed preparation system and a $1 / 10$-scale melter. These factlittes include the melter, offgas, and feed systems that could be used for testing with HWVP stmulant foed. The IDMS has been specifically constructed to provide capabllity for evaluation of DWPF flowsheet processes including precipitate hydrolysis actd addition and mercury stripping. Testing in the IDMS for the DWPF is expected to be completed by the end of the second quarter of FY 1991; therefore, this facllity could be used to conduct tests for the HWVP in late FY 1991 and/or FY 1992 to provide insight into feed processing behavior. 


\subsubsection{Scope}

Testing or processing veriftcation using avallable equipment/factllttes at the SRS is included in this task. A specific test with feed containing some or all of the above components has been identifled for further negotta. tion with SRS marlagement.

\subsubsection{Status}

Inttlal contacts have been made with SRS management to discuss the possibllity of conducting a test for HWVP in the IDMS factlity. Further evaluation and negotfations are planned in support of the planned testing in FY 1992.

\subsubsection{Remaining Task}

Completion of the following task will close this issue.

- Perform an integrated test in the IDMS at the SRS with the NCAW feed composition containing spectfitc components (1.e., chlorides, cadmlum, mercury, uranium, and noble metals) that may not be fully tested in other factlittes.

\subsubsection{Schedule Requitrements}

Further planning and negatlations with the SRS staff will be needed to develop a detalled schedule for this work. The milestones 1isted in Table 8-3 were established for closure of this tssue (see summary schedule, Flgure 11-1, in Section 11.0).

\subsubsection{Costs}

The cost breakdown shown below was established for closure of this issue (expense dollars in thousands). This cost is preliminary and allows for several months of IDMS operation. If noble metals are added to the feed, the operation time would be reduced to compensate for the added costs of feed preparation.

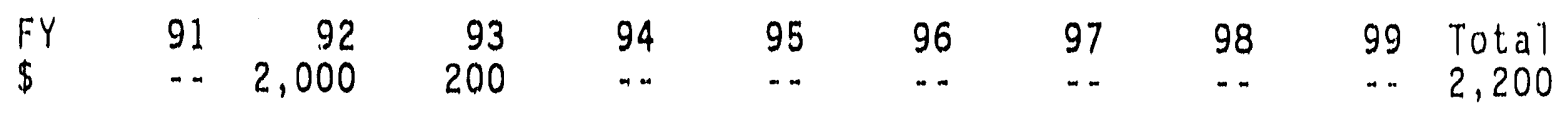


Table 8-3. Process Testing in the Intograted Defense Waste Processing Factlity Melter System Mllestone List.

\begin{tabular}{|c|c|c|}
\hline Mllestone & $\begin{array}{l}\text { Completion } \\
\text { date } \\
\text { (quarter/Fy) }\end{array}$ & Milestone description \\
\hline 1 & $2 / 1992$ & Issue test plan for IDMS run \\
\hline 2 & $4 / 1992$ & $\begin{array}{l}\text { Complete IDMS run using HWVP simulant feed } \\
\text { to provide data for feed preparation and } \\
\text { melter performance assessment }\end{array}$ \\
\hline 3 & $2 / 1993$ & Issue meiter run report \\
\hline
\end{tabular}




\subsection{WASTE FORM QUALIFICATION TESTING - WESTINGHOUSE HANFORD (WBS: 1.2 .5 .03 )}

\subsection{ANALYTICAL STANDARDS AND METHODS ADAPTATION \\ (WBS: $1.2 .5 .03 .03 / 1.2 .5 .03 .04$ )}

\subsubsection{Statement of Issue}

The HWVP must be able to analyze liquid, slurry, and glass samples with suffictent preciston and accuracy to demonstrate that 95 percent of the vitrifled waste form meet the repository leach rate release criterta at the 95 percent confidence level (Waste Acceptance Preliminary Specifications for the Defense Waste Processing Facility High-Level Waste Form, Section 1.3.2) (DOE-OCRWM 1986). To accomplish this level of certainty in reporting, HWVP must develop WFQ testing methods and an analytical statistical database for Westinghouse Hanford analytical laboratory systems. This task will identify the spectfic data needs, adapt existing analytical methods to meet HWVP needs, and develop a database sufficlent to support the 95 percent confidence $11 \mathrm{mit}$ repository criteria. The testing methods and analytical database need to be developed to support WFQ in particular, but they will also have process control applitcabtlity.

\subsubsection{Scope}

This task will incorporate existing analytical methods into Westinghouse Hanford systems and procedures. In addition, this task will establish a set of analytical standards, define needed analytical sensitivity for the expected composition matrixes, conduct round-robin tests, and establish the laboratory's requisite sample size, the number of replicate samples or analyses, and calibration standards. Duplicate analyses or round-robin testing will involve a number of other laboratories (DWPF, WVDP, Materials Characterization Center, PNL, Catholic University, Corning Laboratories, etc.) for compartson and analysis of analytfcal data. The analytical methods pertinent to WFQ include, but are not 1 imited to, leach testing, glass phase (crystal) characterization, ICP analysis of leachate samples and glass samples, and ton chromatograph.

\section{1 .3 Status}

Work has not been initfated on this technical issue. Some PNL analytical methods have been, and will continue to be, developed. These methods will be transferred to the Westinghouse Hanford analytical laboratories.

\subsubsection{Remaining Tasks}

The following activittes are necessary to complete this task.

- Review and adapt extsting PNL and DWPF analytical methods to HWVP.

- Test analytical methods for precision and accuracy. 
- Identify WFQ statistical needs for standards and replicates.

- Establish and document a WFQ standards program.

- Demonstrate the ability of the methods and standards through testing.

\subsubsection{ScheduTe Requirements} issue.

The milestones listed in Table 9-1 were established for closure of this

\section{1 .6 Costs}

The following cost breakdown was established for closure of this issue (expense dollars in thousands).

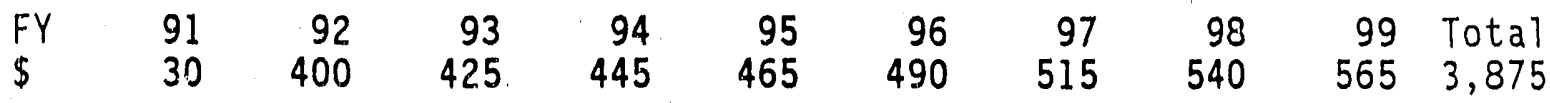

These costs are based on an estimated level if effort to be established in FY 1992 and continued until Project completion in FY 1999. Further development of a detailed cosi breakdown for each fiscal year and identification of all activities to be conducted under this task is planned during FY 1991. 
WHC-EP-0350

Table 9-1. Analytical Standards Milestone List.

\begin{tabular}{|c|c|c|}
\hline Milestone & $\begin{array}{l}\text { Completion } \\
\text { date } \\
\text { (quarter/FY) }\end{array}$ & Milestone description \\
\hline 1 & $4 / 1991$ & $\begin{array}{l}\text { Define design issues and maintain technical } \\
\text { interface with Fluor }\end{array}$ \\
\hline 2 & $4 / 1992$ & $\begin{array}{l}\text { Complete an overall analytical standards } \\
\text { development plan and a draft of analytical } \\
\text { procedures }\end{array}$ \\
\hline 3 & $4 / 1993$ & $\begin{array}{l}\text { Initiate round-robin testing and establish } \\
\text { ICP leach rate and glass crystalline phase } \\
\text { calibration standards }\end{array}$ \\
\hline 4 & $4 / 1994$ & $\begin{array}{l}\text { Define precision and accuracy for a } 11 \\
\text { analytical methods }\end{array}$ \\
\hline 5 & $4 / 1995$ & $\begin{array}{l}\text { Define precision and accuracy for leach rate } \\
\text { and crystalline phase methods }\end{array}$ \\
\hline 6 & $3 / 1996$ & $\begin{array}{l}\text { Complete DWPF analytical method adaptation } \\
\text { to HWVP }\end{array}$ \\
\hline 7 & $3 / 1997$ & Establish standards and a replicate program \\
\hline 8 & $3 / 1998$ & $\begin{array}{l}\text { Test and document analytical methods and } \\
\text { uncertainty }\end{array}$ \\
\hline
\end{tabular}




\subsection{COST ESTIMATF. SUMMARY}

A cost estimate summary, including expense and CENRTC, is presented in Table 10-1. The estimated total cost for work from FYs 1991 through 1999 described in this Plan is $\$ 136,840,000$ expense and $\$ 15,490,000$ CENRTC. Costs for technology work performed by PNL preceding FY 1986 totals $\$ 6,235,000$. The PNL cost totals $\$ 1,774,000$ in FY $1986 ; \$ 2,560,000$ in FY $1987 ; \$ 1,575,000$ in FY 1988; $\$ 3,822,000$ in FY $1989 ;$ and $\$ 6,952,000$ in FY 1990 . Costs including and following FY 1991 are based on estimates in FY 1990 dollars, and they are escalated to the year of expenditure. Escalation factors are shown at the top of Table 10-1.

A listing of CENRTC costs for equipment that will be used in the testing activities is also presented in Table 10-1. The work described in this Plan is dependent on timely availability of CENRTC funding.

Estimated cost and schedule data in this document are for planning purposes only. Cost and schedule baselines are documented elsewhere. The total technology costs in this Plan are consistent with the total Technology costs included in the FY 1992 budget submittal for the HWVP Project.

Technology activities for FYs 1991 and 1992 are also consistent with the key activity summary and priority list included in the FY 1992 budget submittal. 


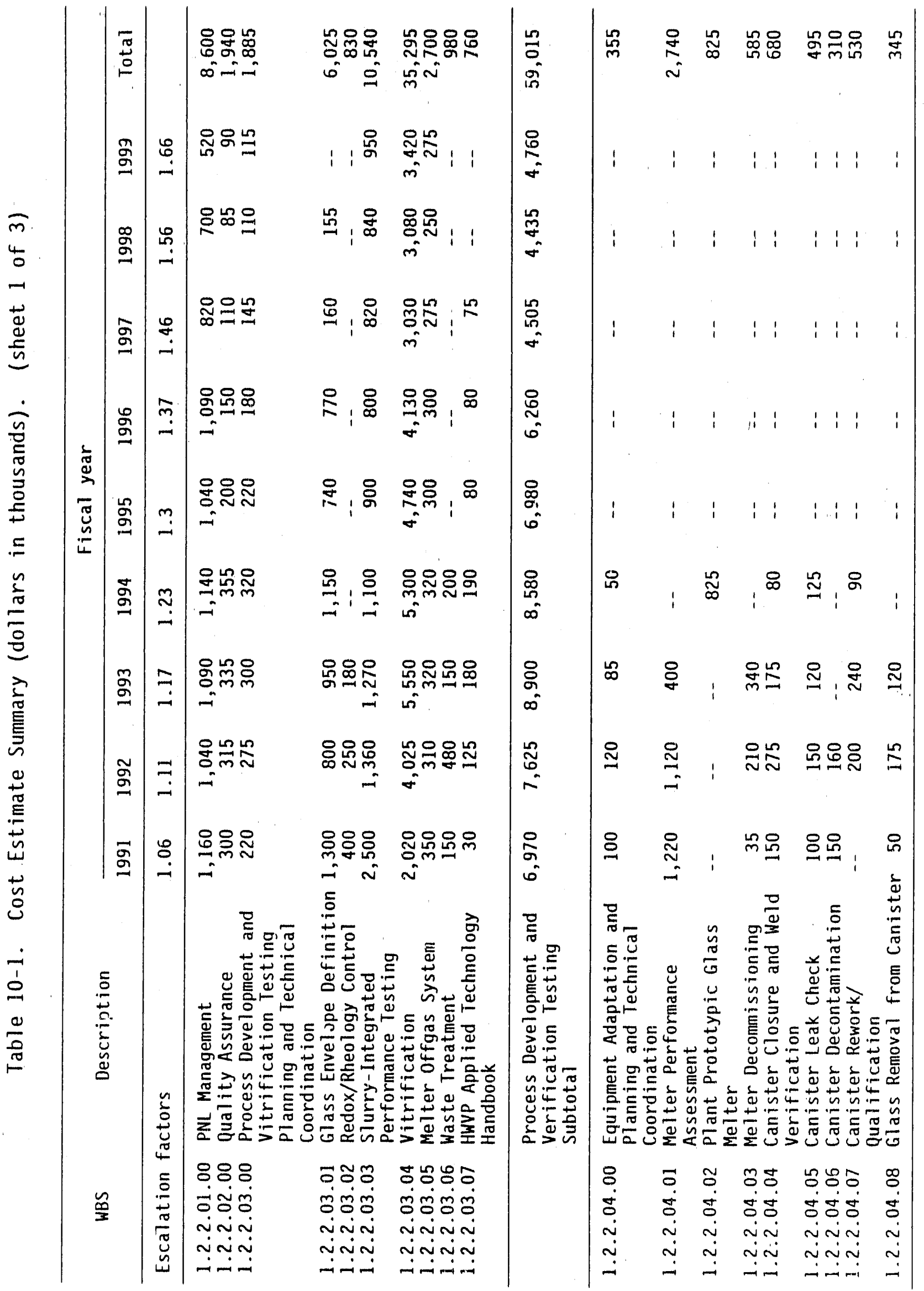




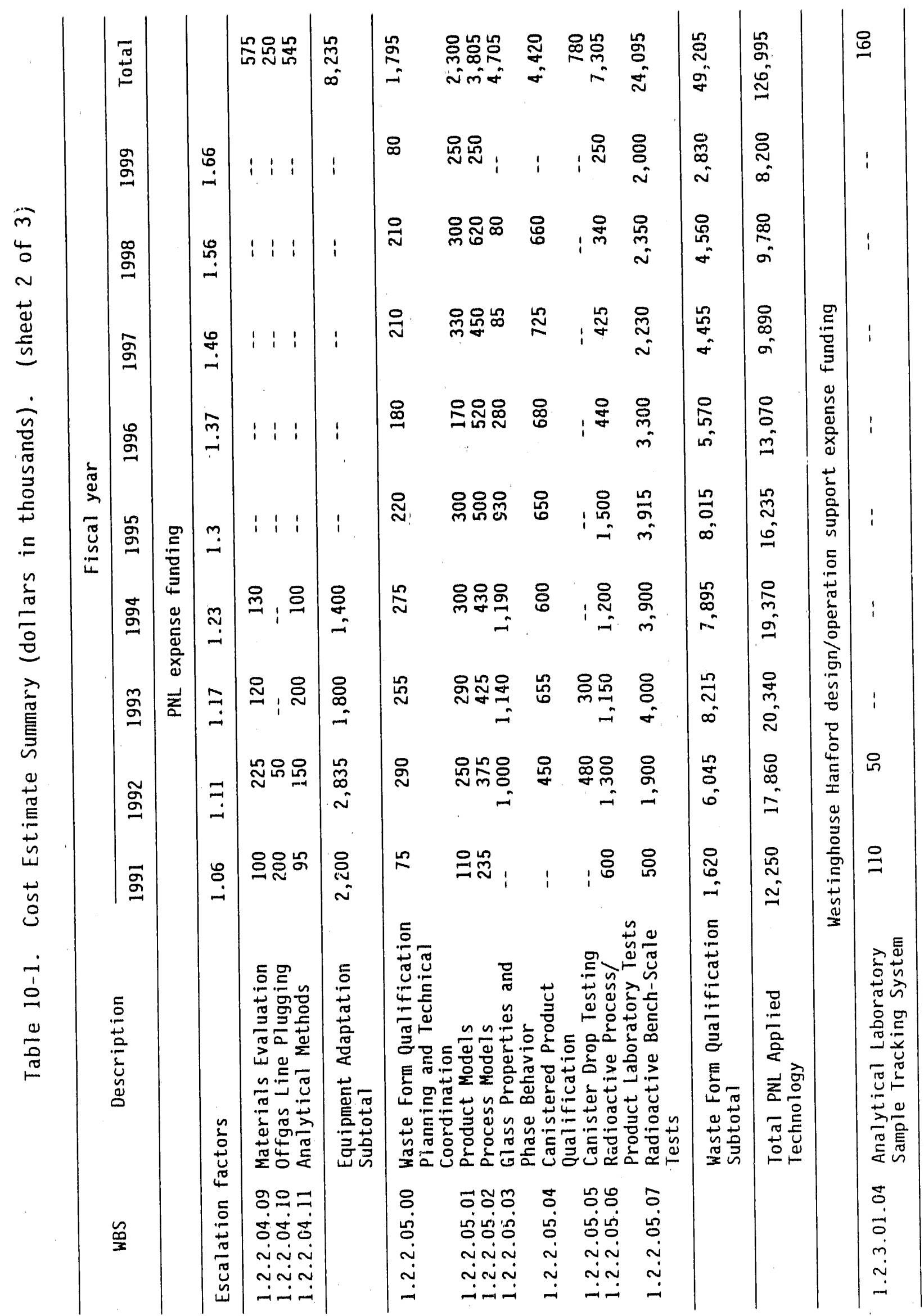




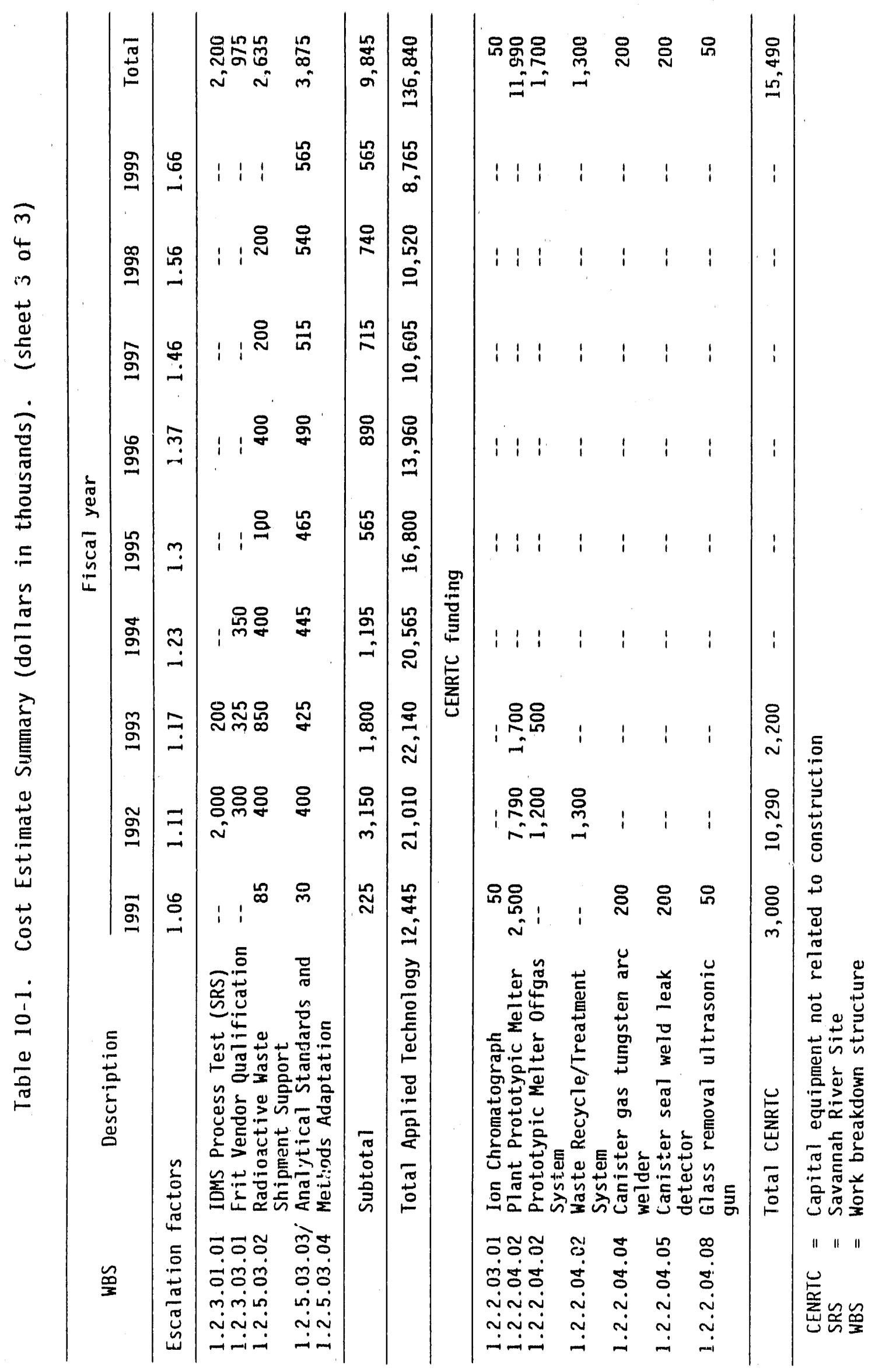




\subsection{SCHEDULE}

The Applfed Technology Plan summary level schedules shown in Figure 11-1 graphically display implementation of the Applied Technology activities conducted by PNI. relat ive to the Westinghouse Hanford planned work. Vartous major Project schedule elements are shown, including those that interface with the applied technology activities.

The major interfaces from Applfed Technology (other than wasle form compliance and WFQ, which must be completed before hot startup) are provided by a sertes of glass melter test runs and include the following work:

- Evaluations of equipment adapted from DWPF or WVDP

- Material evaluations

- Process and melter verification tests with a range of feed composttions

- Melter performance assessment input

- Waste treatment design verification

- MOG system performance verification

- Comptlation of the technology database

- Process operations and control database.

These activities provide direct support to plant design, melter design, process equipment design, process control design, preparation of HWVP operating procedures, maintenance planning, the FSAR, and readiness review.

Although this $P 1$ an does not include a description and cost breakdown for a11 the HWVP technology-related activities, the schedule shows the relationship with other technology work identified in the HWVP WBS. The various WBS elements that provide for Technology and WFQ implementation including permitting are as follows:
1.2.1 - Technology Base/Exchange (Westinghouse Hanford)
1.2 .2 - Vitrification System Technology Definition (PNL)
1.2 .3 - Technology Integration and Transfer (Westinghouse Hanford)
1.2 .4 - Pretreatment and Characterization Technology Definttion (Westinghouse Hanford)
1.2.5 - WFQ Technology Definition (Westinghouse Hanford)
1.4.4.01 - WFQ Compliance

The 1.2.5 and 1.4.4.01 work elements are incorporated because of the necessity of direct integration of 1.2 .1 to 1.2 .4 work into WFQ and complitance. 


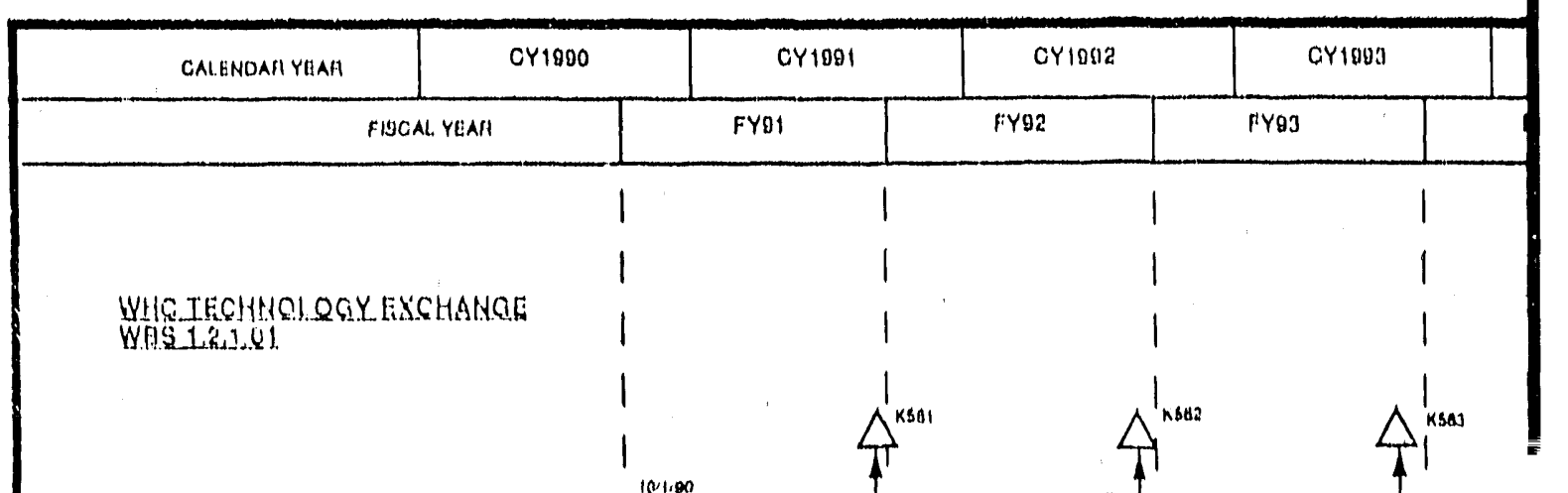

TECHNOLOCY EXCHANOA PLANNINO \& COOHOINATION 112.101011

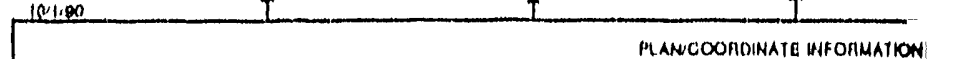

OWPFNYOP

TECHNOLOAY EXCIUNAE

1121.01021

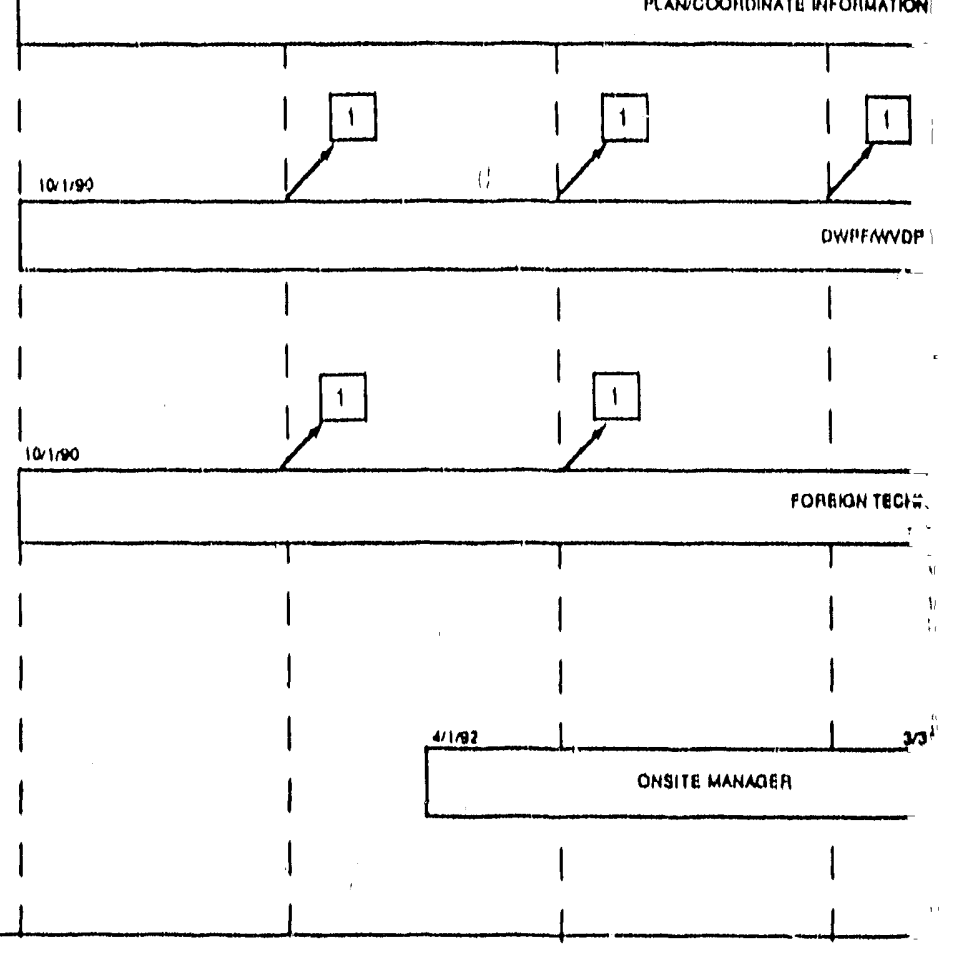

FORLION TECHIMOLOOY

EXCHANGE

(12.101.031

WYOP ONBITE MUNAGEA
(1.2.01.0.1)

MILESTO:

$K 501$ LSSUE FISCAL YEAF 1992 TE

$K$ SO2 ISSUI FISCAL. YEAOI $1000 \mathrm{YH}$

$K$ SNO ISSUE FISCAL. YEAA IOOA YEK

$K$ S34 ISSUE FISCAL YEAFI IOOS TEK

$K$ SBS ISSUE FISCAL YEA 1000 TEK

$K$ SOO ISSUEE FISCAL. YEAFI 1907 TE

K 2.1.01A ISSUE FISCAL YEAH 1000 TE 
Figure 11-1. Hanford Waste Vitrification Plan Technology Summary Schadulo. (sheet 1 of 13)

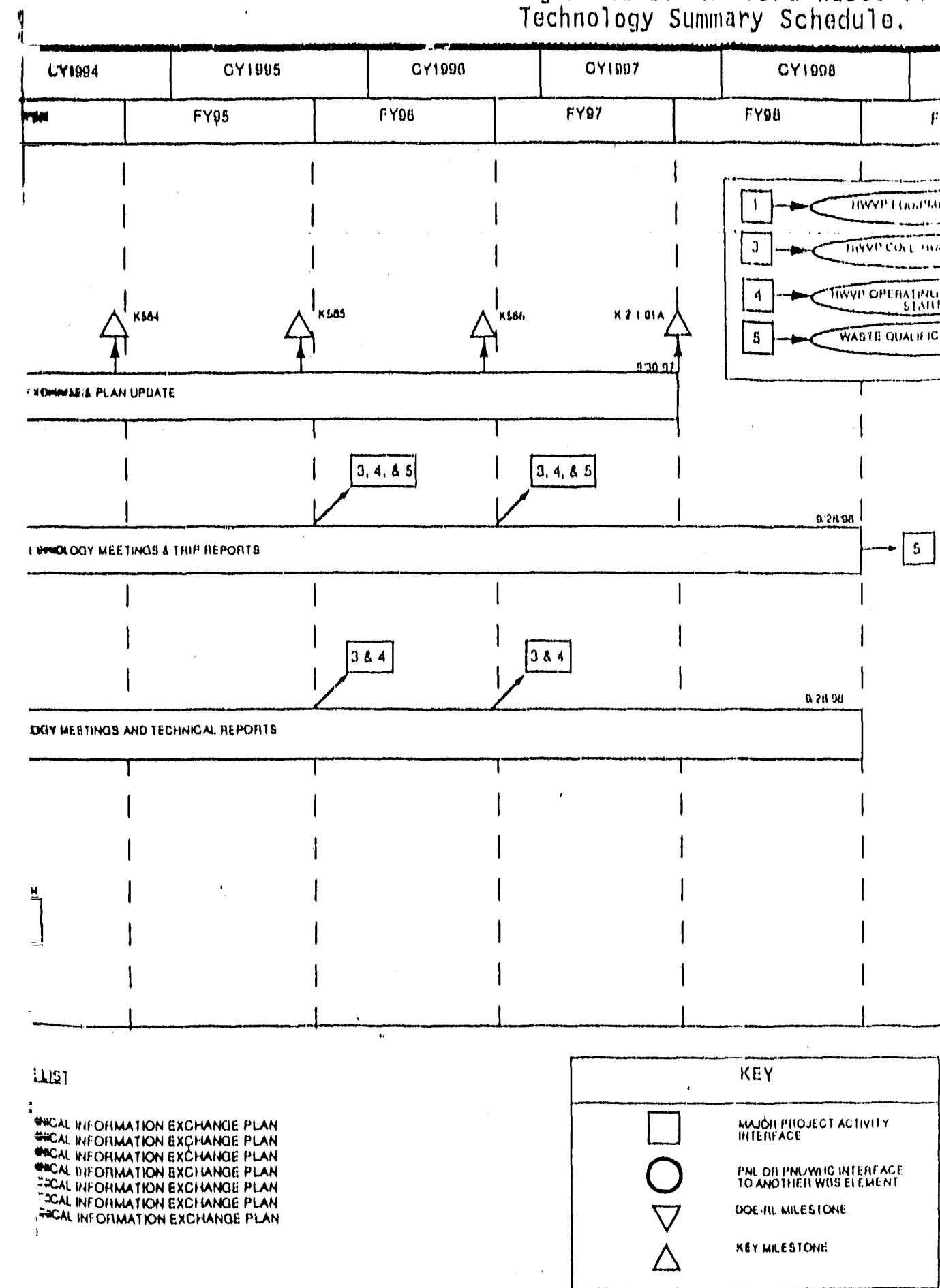




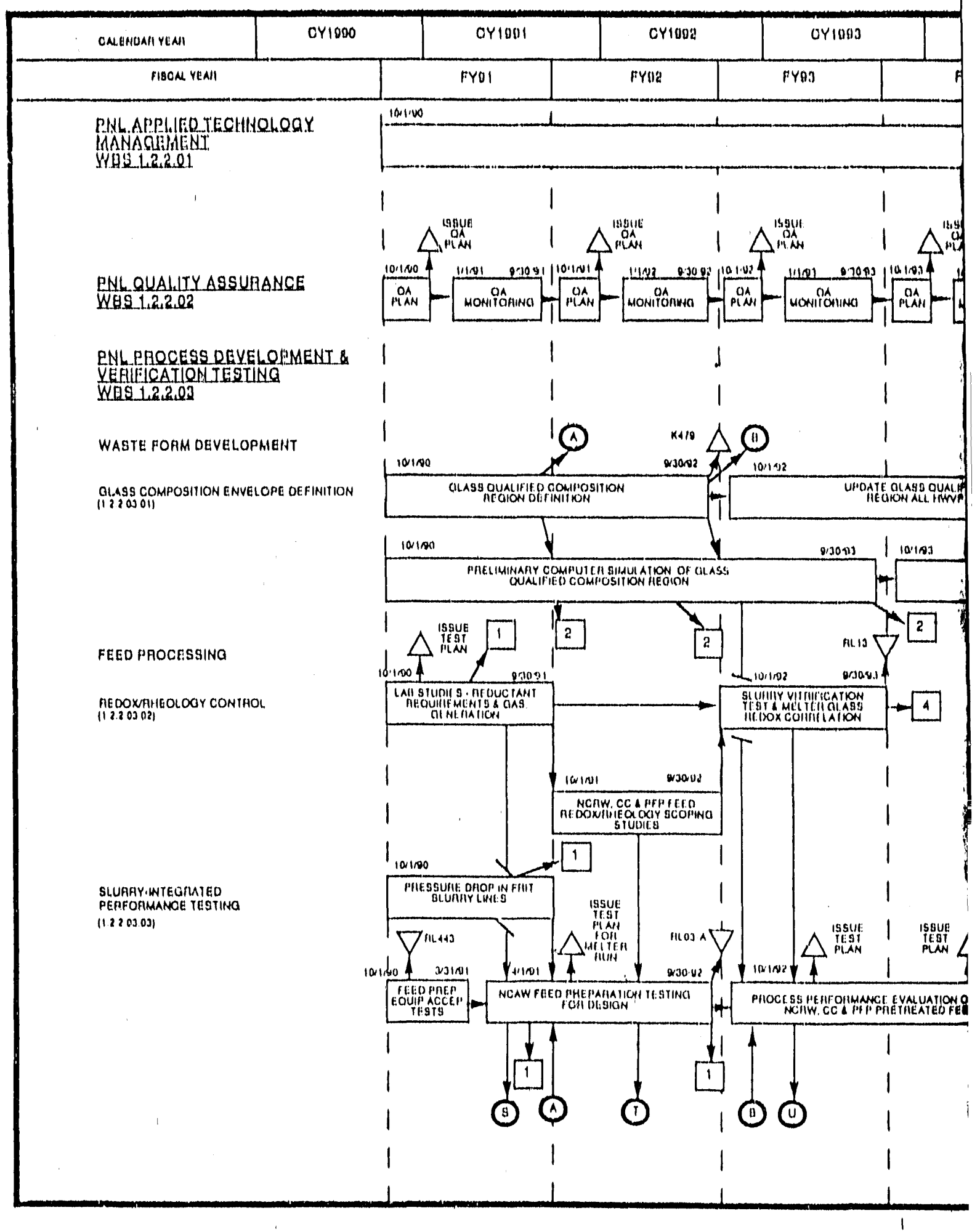


Flgura 11-1. Hanford Waste Vitriftcation Plan Technology summary schedula. (sheet? of 13)

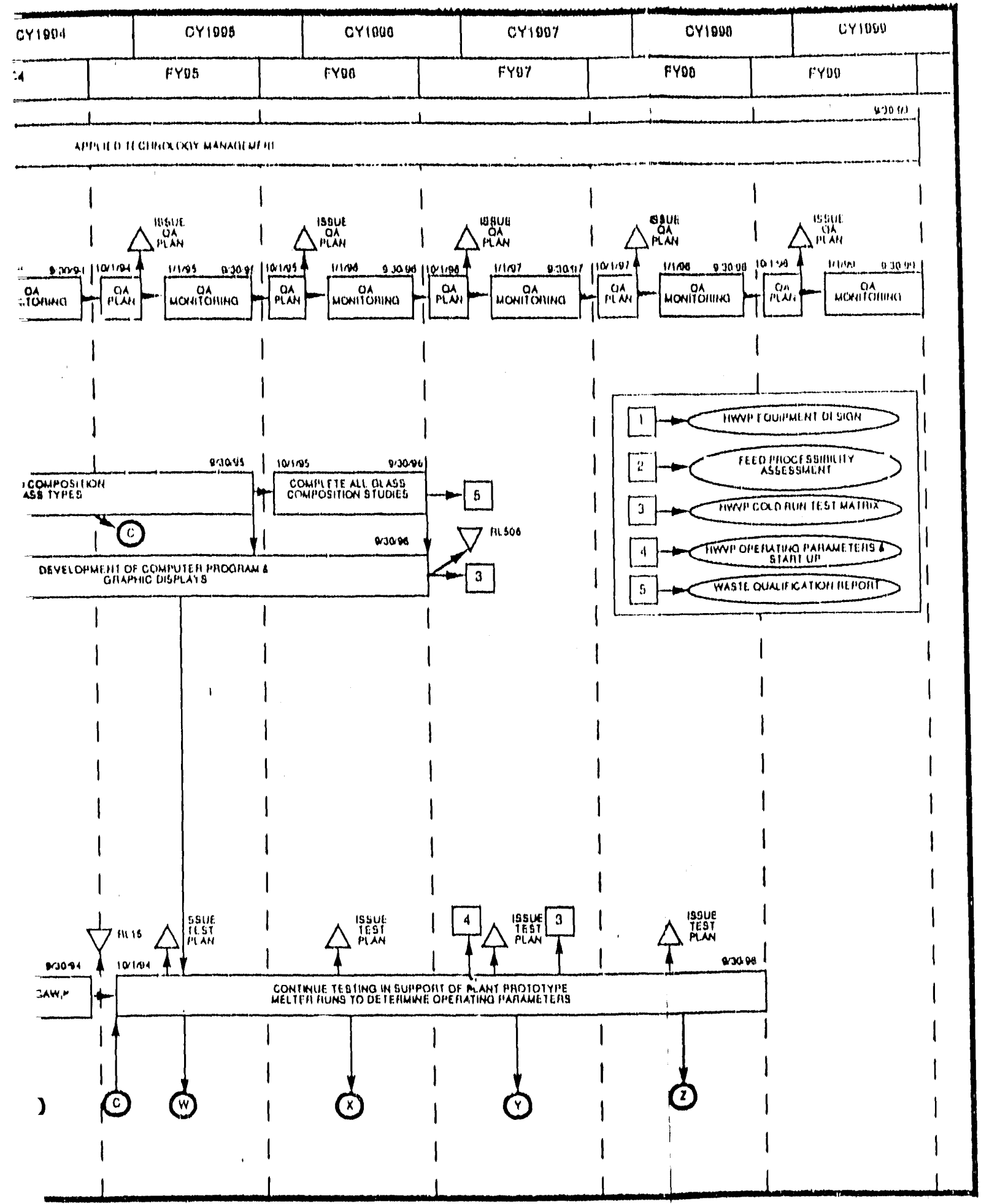




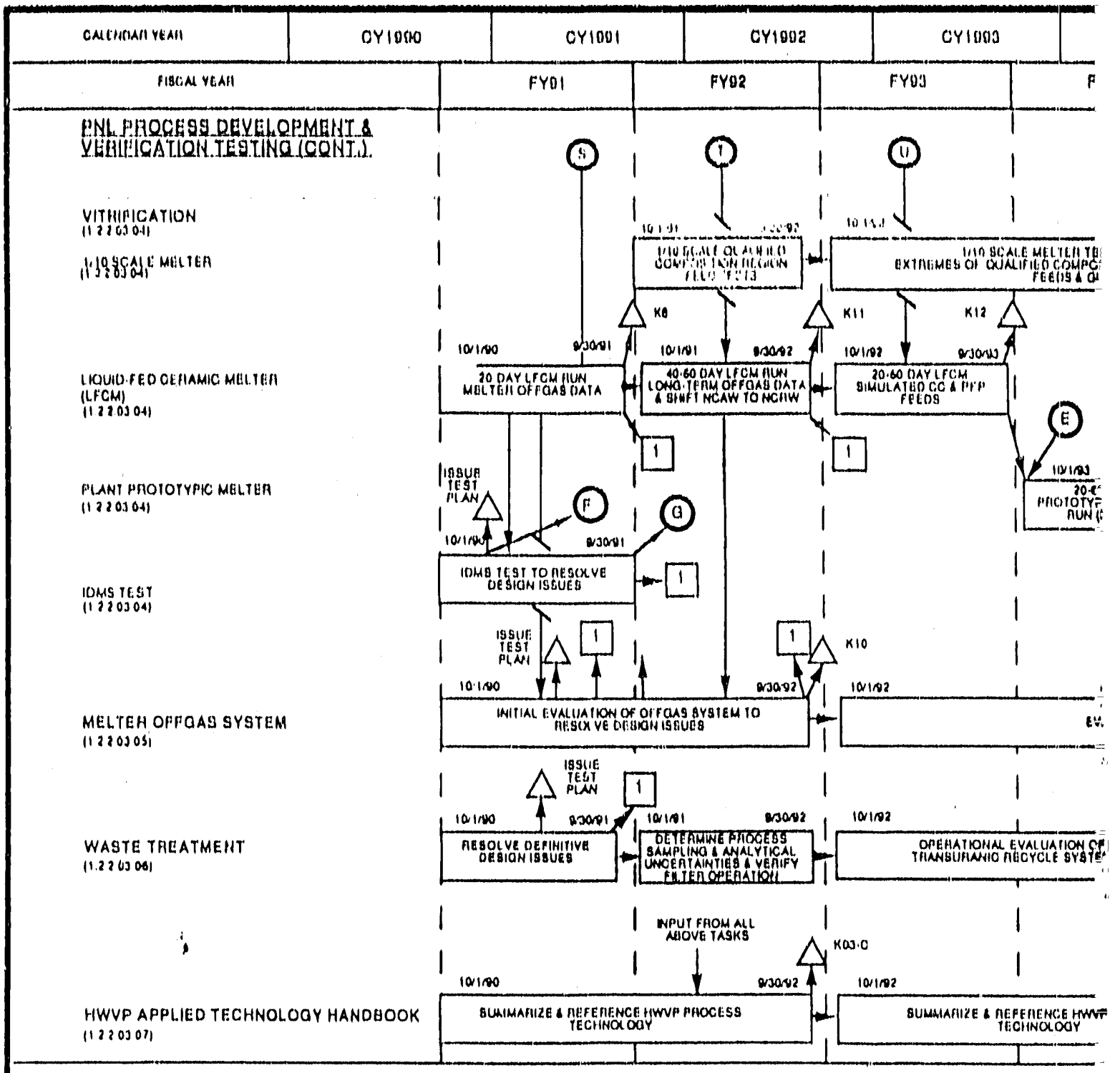

MILESTENES.LIST,

HL 443 ISSUE APPHOVED TEST PLAN FON SLUAHY.INTEOHATED PERFOHMANCE TESTINO

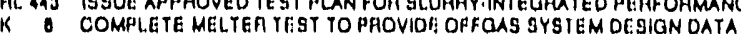

$K$ II COMPLETE MELTEA TEST YO PIOVIDE LOHO TERUIOFFOAS AND COMPOSITION SHIFT DATA

$K 470$ PROVIOE OEFINIYION OF YHE OUASS DUALFIEO COMPOSITION AEOION

AL 03.A COMPLETE FELO PAEPAAUTKO WOH MIXINO CHAFUCTEHISTICS TESTING FOH OESLON

$K$ 12 COMPLETE MELTEA TESTINC OF C.C \& PFP

$K$ IO MELTEA OFFOAS SYSTEM DESION VEFHFICATION COMPLETE

AL is COMPLETE OLASS AEDOX CONTHO COFAELATOUS

$K$ OJ.C COMPLETE TECHNOLOCY MANODDOK UPDATE FOH DEFINITIVE DESION
AL 14 COMPLETE SL.UAAYIMELTEA PLANT.PAOTOTYPIC K 370 LSSUE: APPLIED TECHINOLOOY HANOEOOK FOFH' $K$ WO COMPLETE PIANT.PAOTOTYPIC MELTEA TEBTS Y FL. 15 FEEO PAOCESSINO DEVELOPMEHIT COMPLETE K 330 COMPLETE PLANT.PHOTOTYMIC MELTEA TESTS:HLSOO COMPLETE QLASS CHUAACTEAIZATION HOOELW: $K$ SHO COMPLETE PLANT.PAOTOTYPIC MELIEH TESTS : K 03. D COMPLE TE PLANT PIOTOTYPIO HELTEA TESTS: K 04.A COMPLETE EVALUATION OF TRU AECYCLE PEAFC 
Figure 11.1. Hanford Wasto Vitriftcation Plan

Technolagy Summary Schedulo. (shoot 3 of 13)

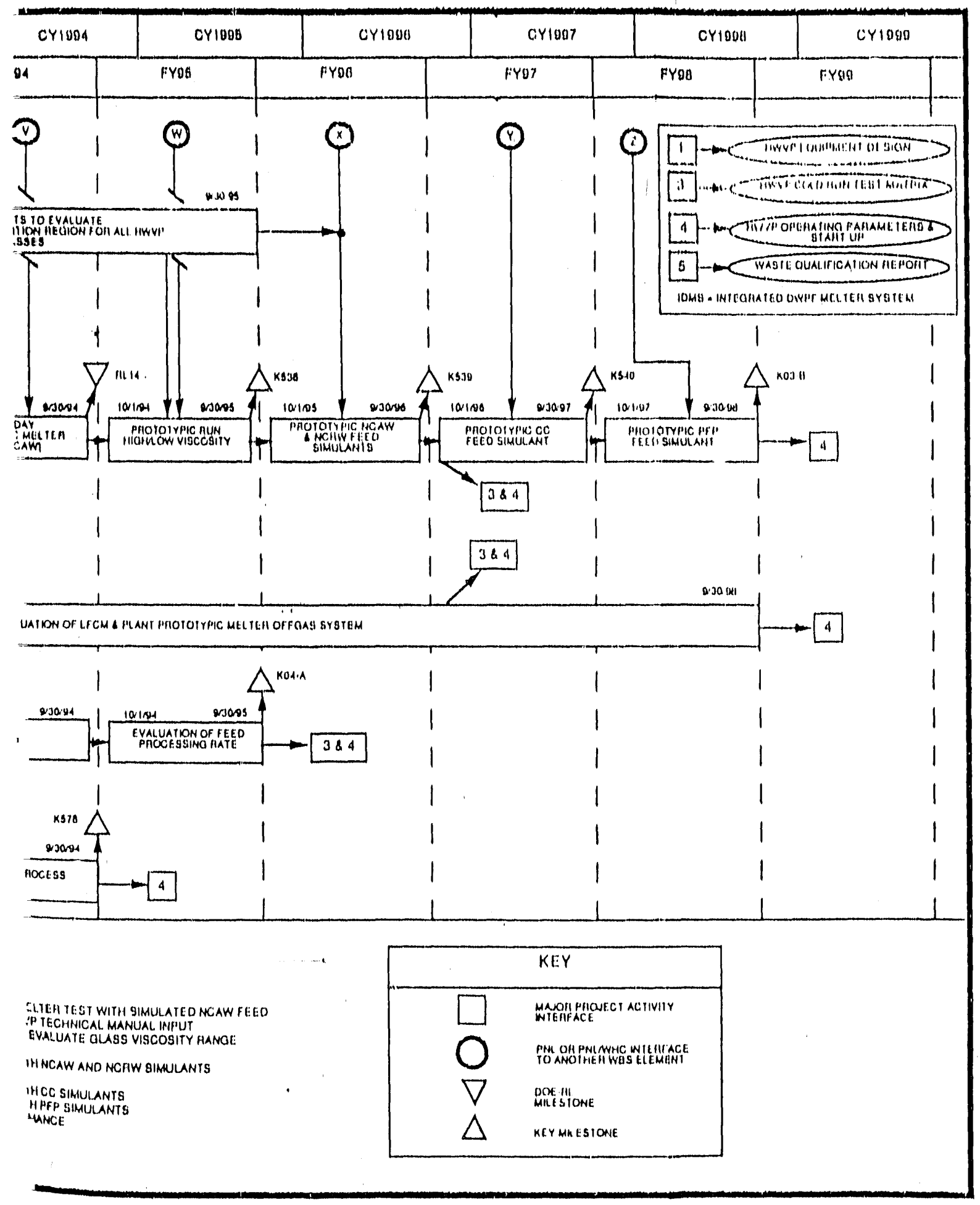




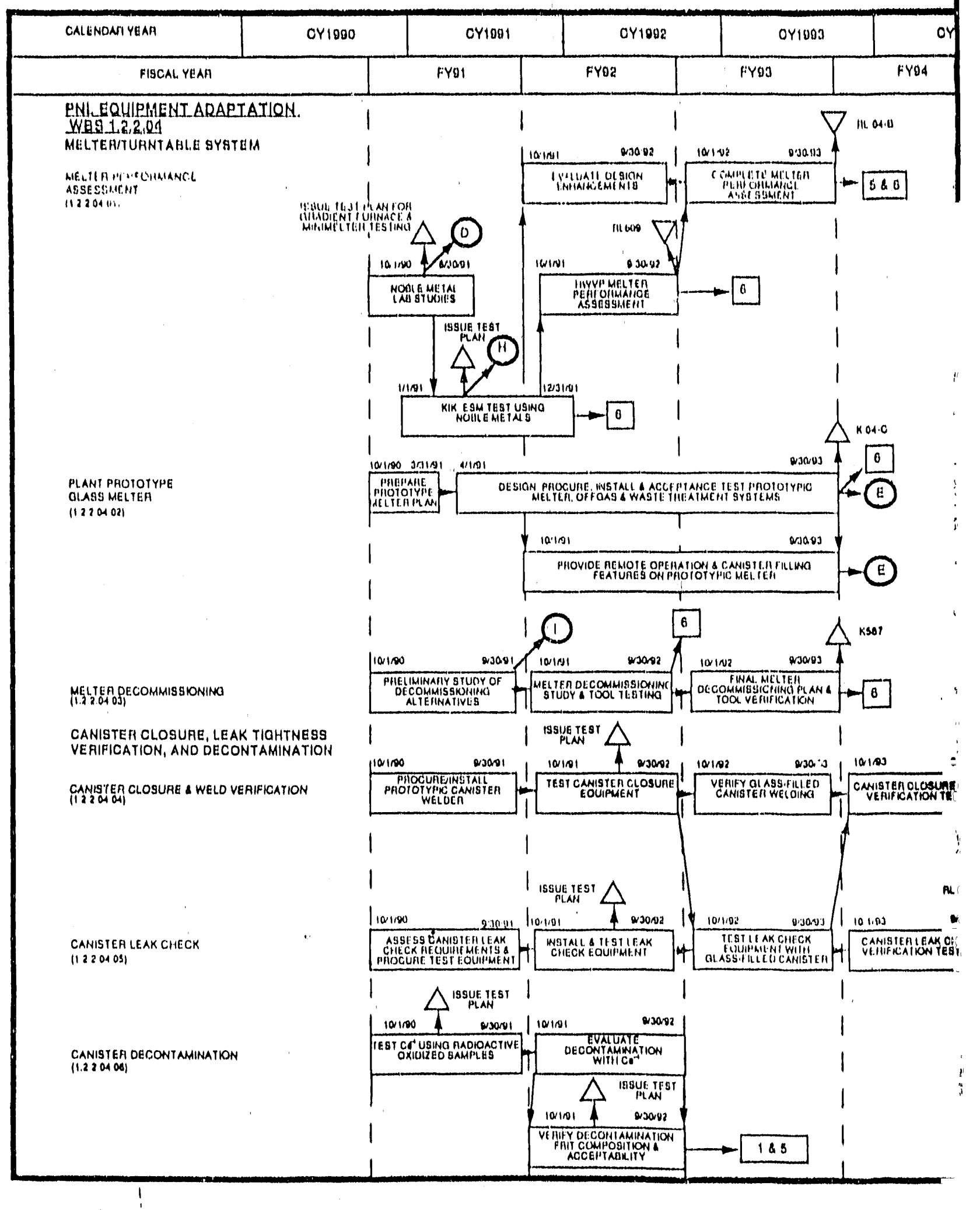


Figure 11-1. Hanford Waste Vitrification Plan Technology Summary Schedule. (sheet 4 of 13)

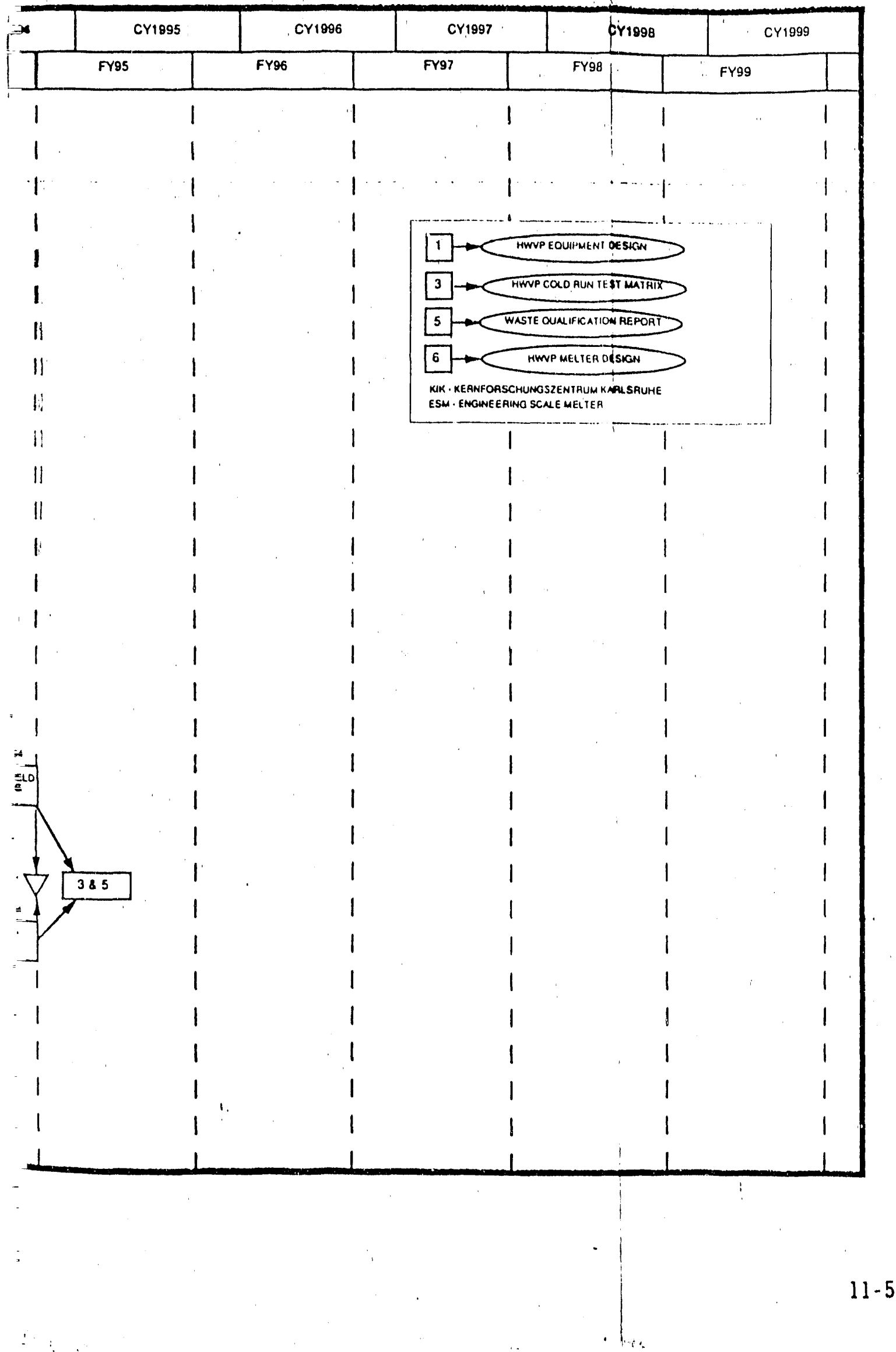




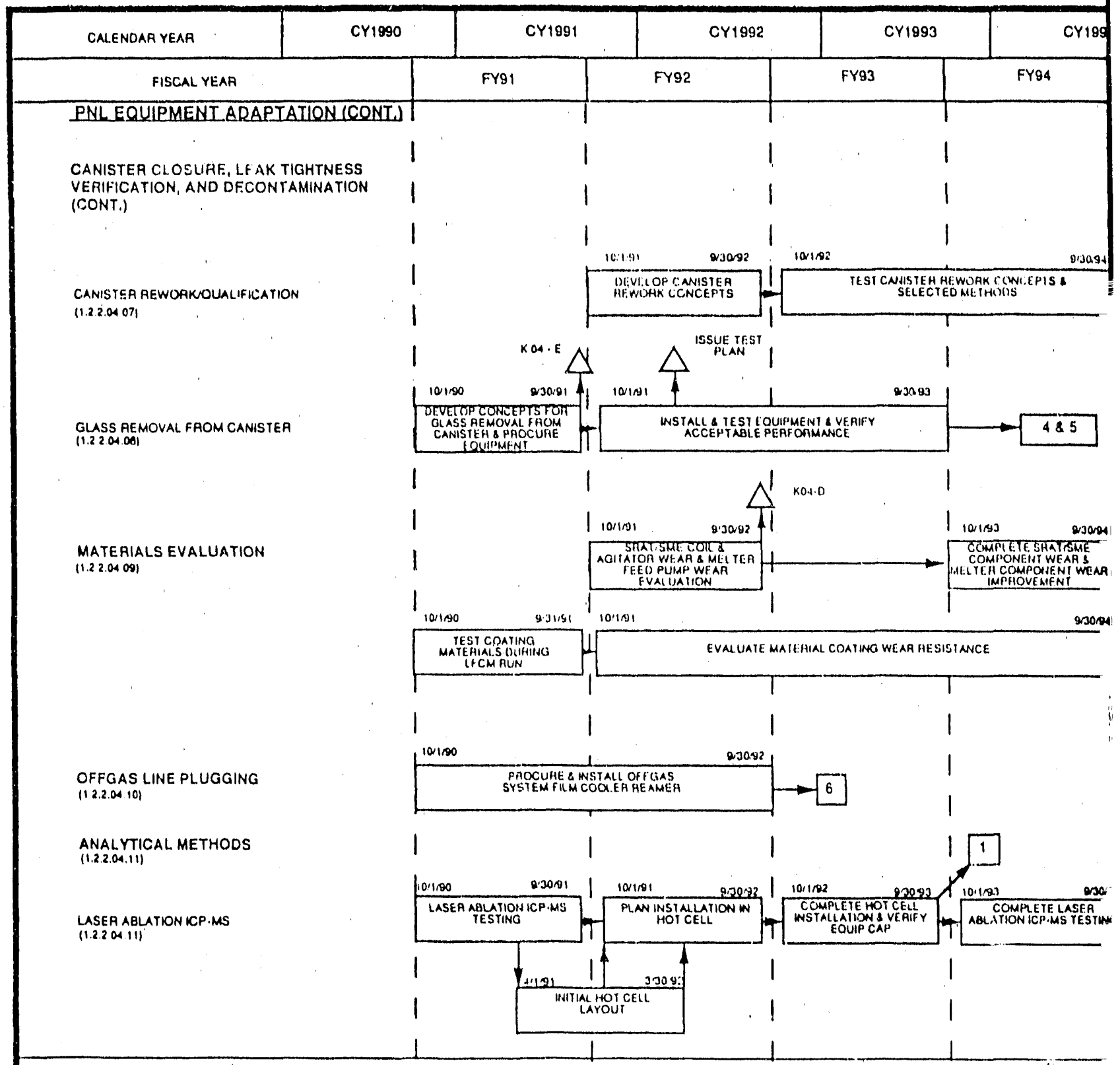

MUI.ESTONE.LISI

RL 609 ISSUE MELTER PHEFOAMANCE EVALUATION REPORT

K 587 PGOVIDE HWVP MELTEA DECOMMISSIONING PLAN INCLUDING REVIEW OF PAM: ALOA.B COMPLETE MELTEA PEAFORMANCE ASSESSMENT

K O4.C COMPLETE INSTALLATION OF PLANT.PAOTOTYPE MELTEA A SUPPOHT SYSTEAE RI.OA.F COMPLETE CANISTEA CLOSURL \& VERIF K.ATION TESTIING

ALOA.L. COMPLETE TESTING OF LASEA ABLATION HCP MS

KOA.D ISSUE MATERIAL WEAA REPOAT

KOH.E ISSUE ENGINEERING STUOY OF GLASS HEMOVAL CONCEPTS 
Figure 11-1. Hanford Waste Vitrification Plan

Technology Symmary Schedule. (sheet 5 of 13)

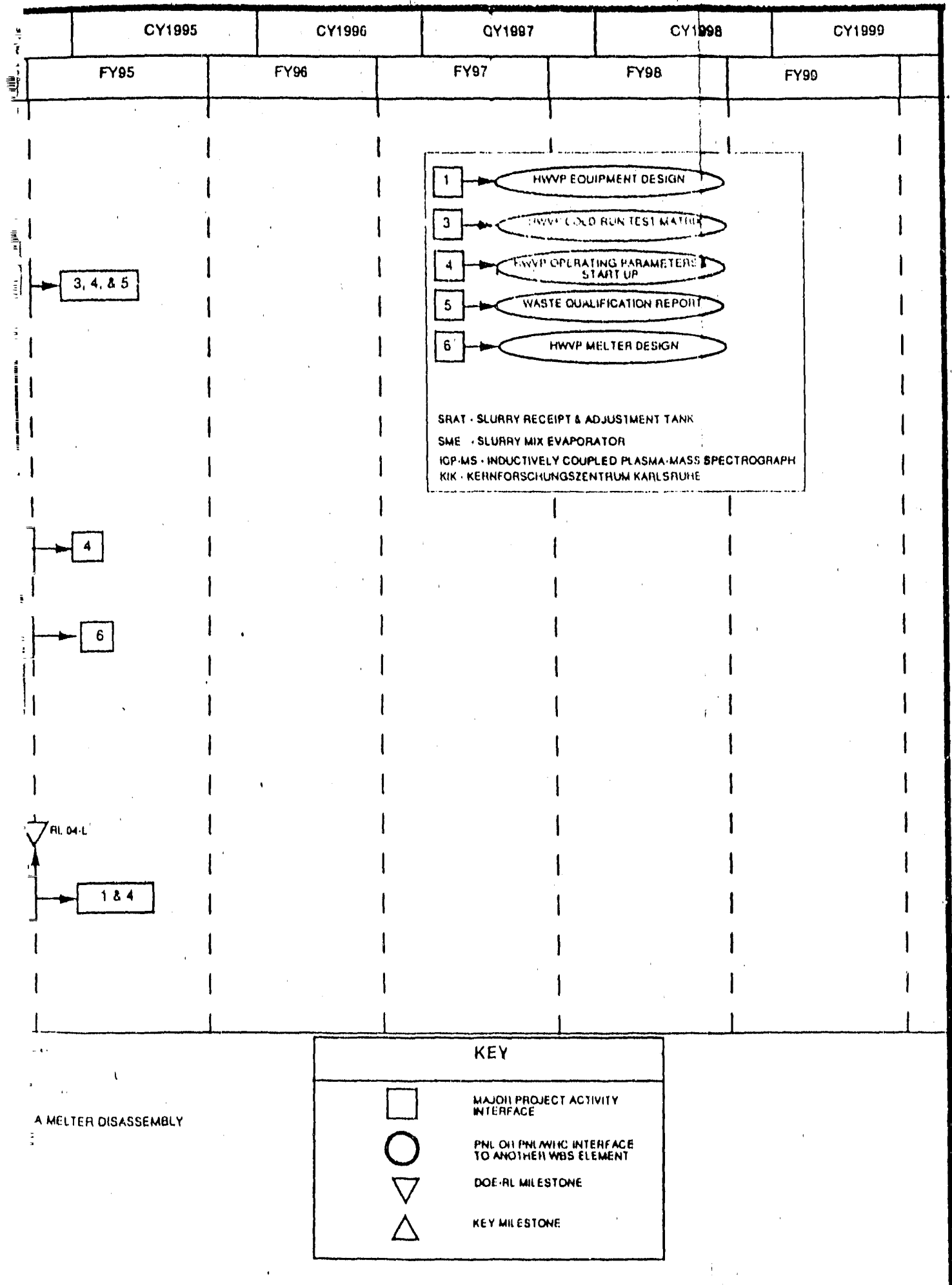




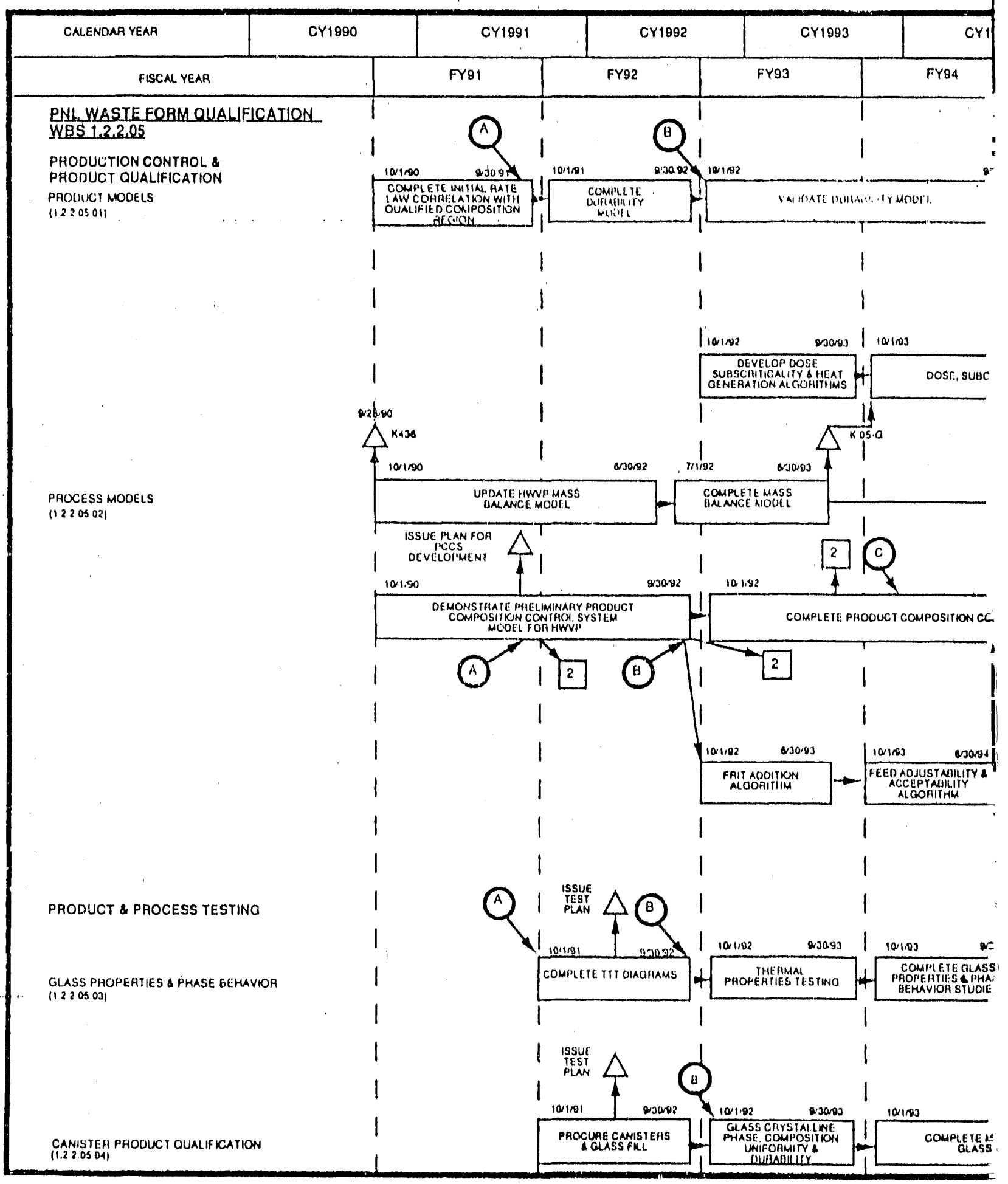


Figure 11:1. Hanford Waste Vitrification Plan

Technology Summary Schedule. (sh!et 6 of 13)

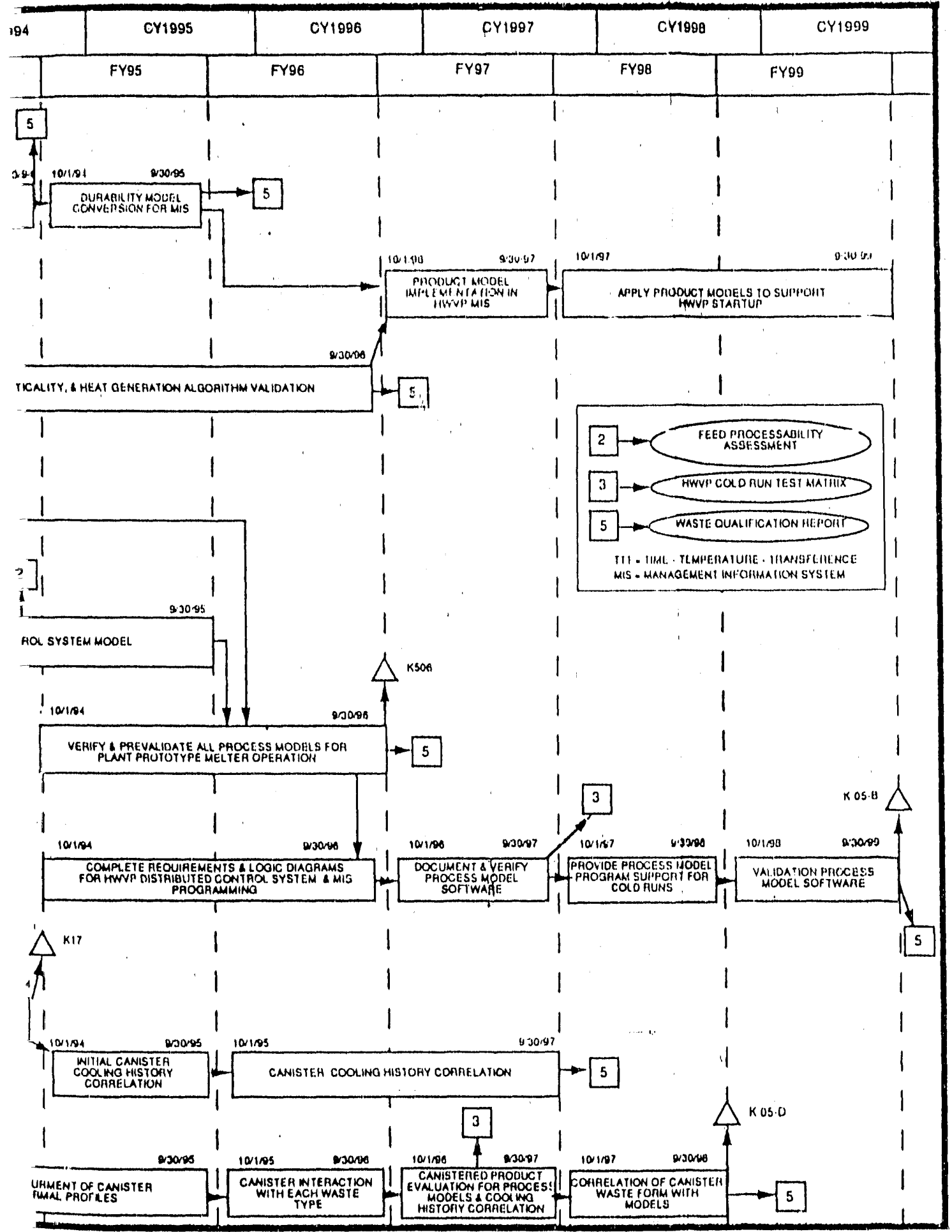




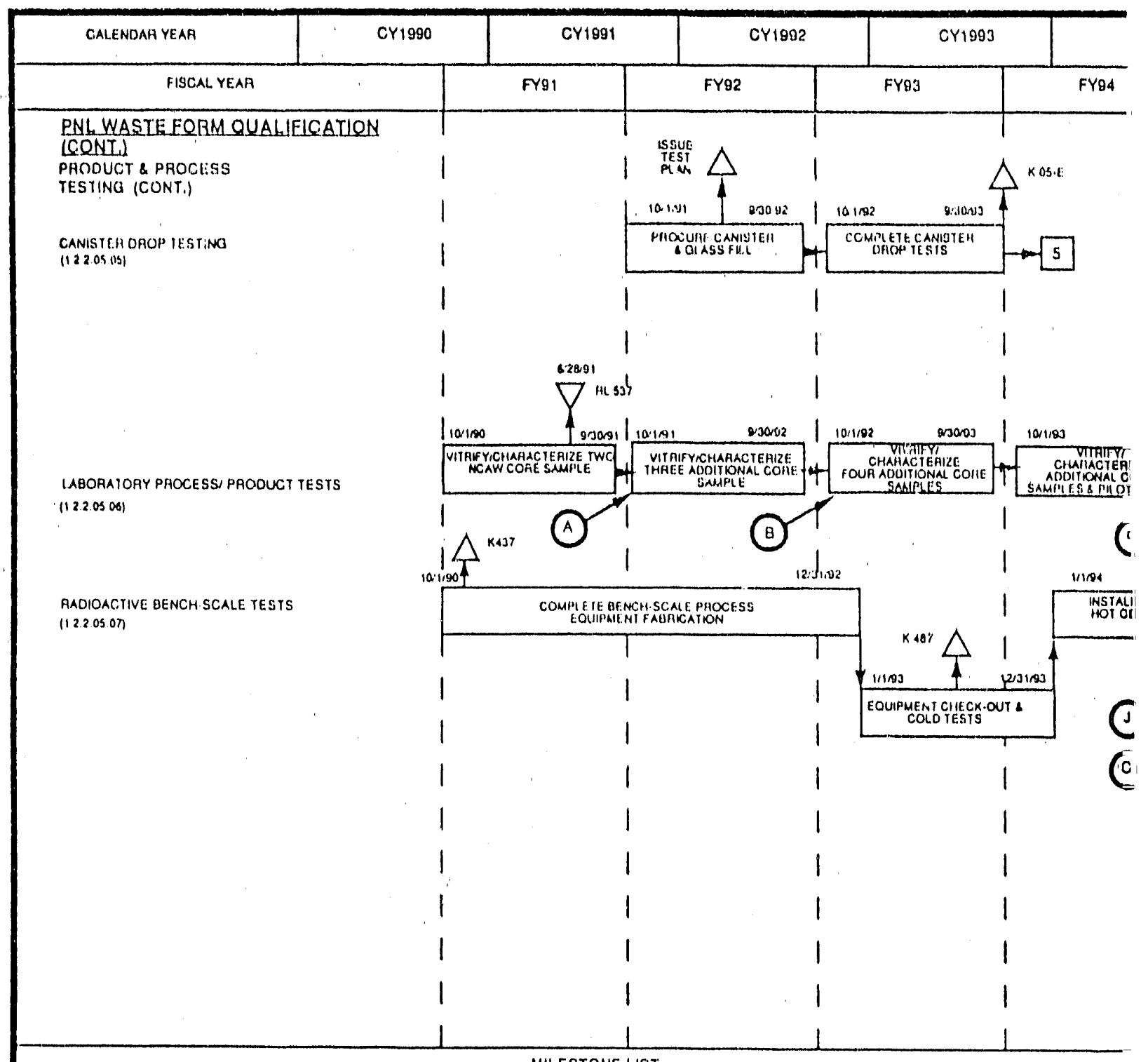

MULESTONELLSI

$K$ 438 ISSUE REPORT DE SCRIBINO :USS BALANCE MOOEL

$K$ 437 ISSUE PLAN FOR RADLACTIVE PROCESS TESTS

RL. 537 ISSUE REPORT ON RAOIOACTINE FORMUTING, VITPIFGATON $\triangle$ PROOUCT TESTS

$K 487$ ISSUE BENCH.SCALE MELTER TEST PLAN FOR SIMULANT FEED

$K$ O5.G COMPLETE UPOATE OF THE MUSS BALANCE COMPUTER FED

KOS.E ISSUE REPOAT ON CANISTEA DROP TEST

AL. 32 COMPLETE BENCH SCALE MELTEA TESTS WITH PUDLOACTIVE NCAW

$K$ SOS COMPLETE DEVELOPMENT OF PROCESS COMPOSITION CONYROL SYSTEM COMPUTEA MOOEL

$K$ i7 COMPLETE QLASS PAOPERTIES \& PHASE STUDIES

RL. 20 COMPLETE BENCH.SCALE ALELTER TESTS WITH AADLOACTIVE NCRW

K 932 COWPLETE BENCH.SALE WELTEA TESTS WTH

$K$ aJS COMPLETE BENCH.SCALE MELTEA TESTS WITH AADIOACTIVE CC SOLIOS

K OS.B PROCESS MOOEL COMPUTEA SOFTWAAE VAL,UATION COMPLETE 
Figure 11-1. Hariford Waste Vitrification Plan Technology. Summary Schedule. (sheet 7 of 13)

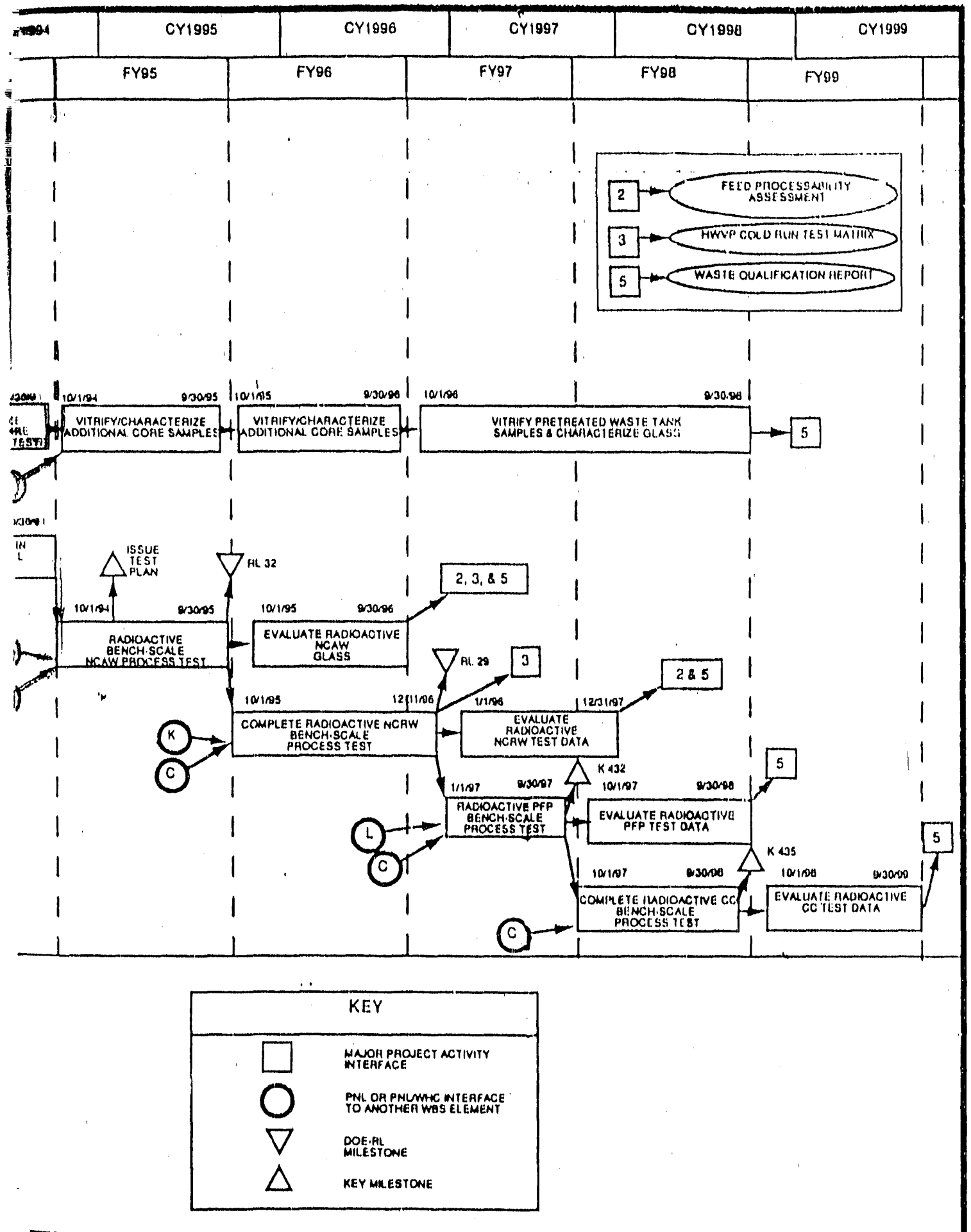




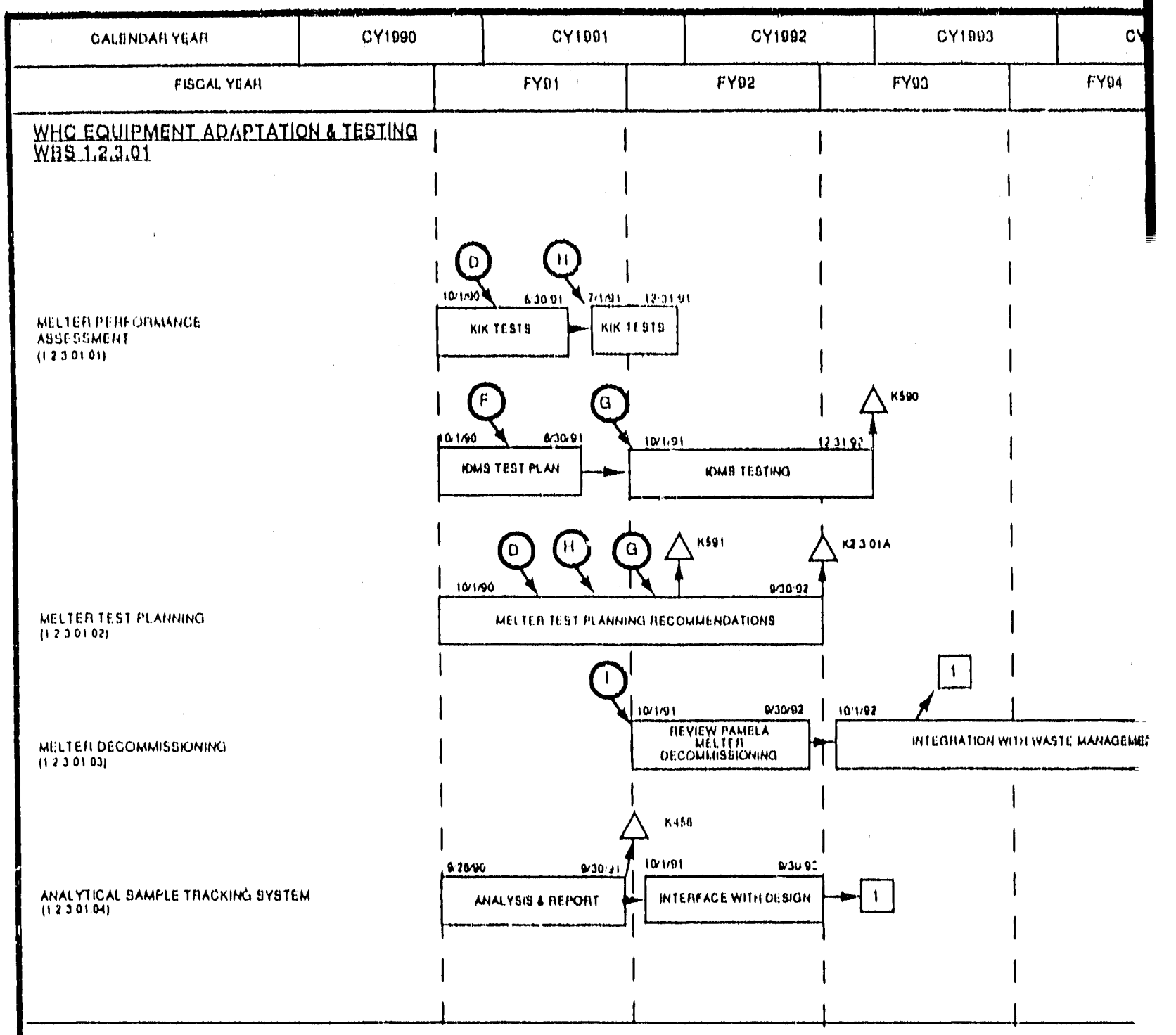

HIILESTOHE. LISI

K 486 ISSUE ANALYYICAL SAMPLE THACKIE:

$K 501$ HEUE UPOATEO MFE THE OL VELOP

$K$ S90 ISSUE IOMS TEST RUN HL:POHT

K 2.J.01A ISGUE MELTENA ASGG SGMENI RECOS 
Figure 11-1. Hanford Waste Vitrification Plan Technology Sumnary Schedule. (sheet 8 of 13)

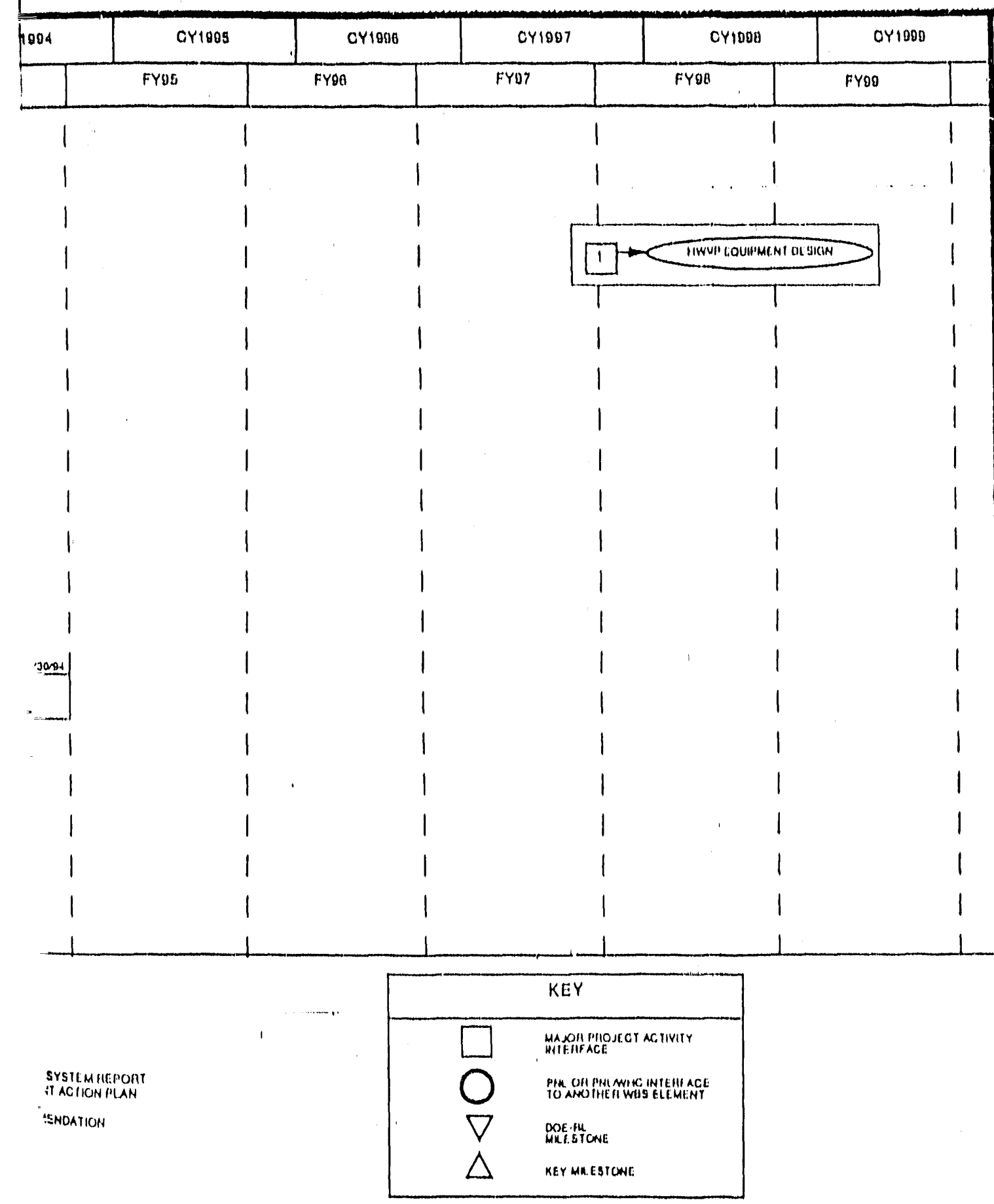




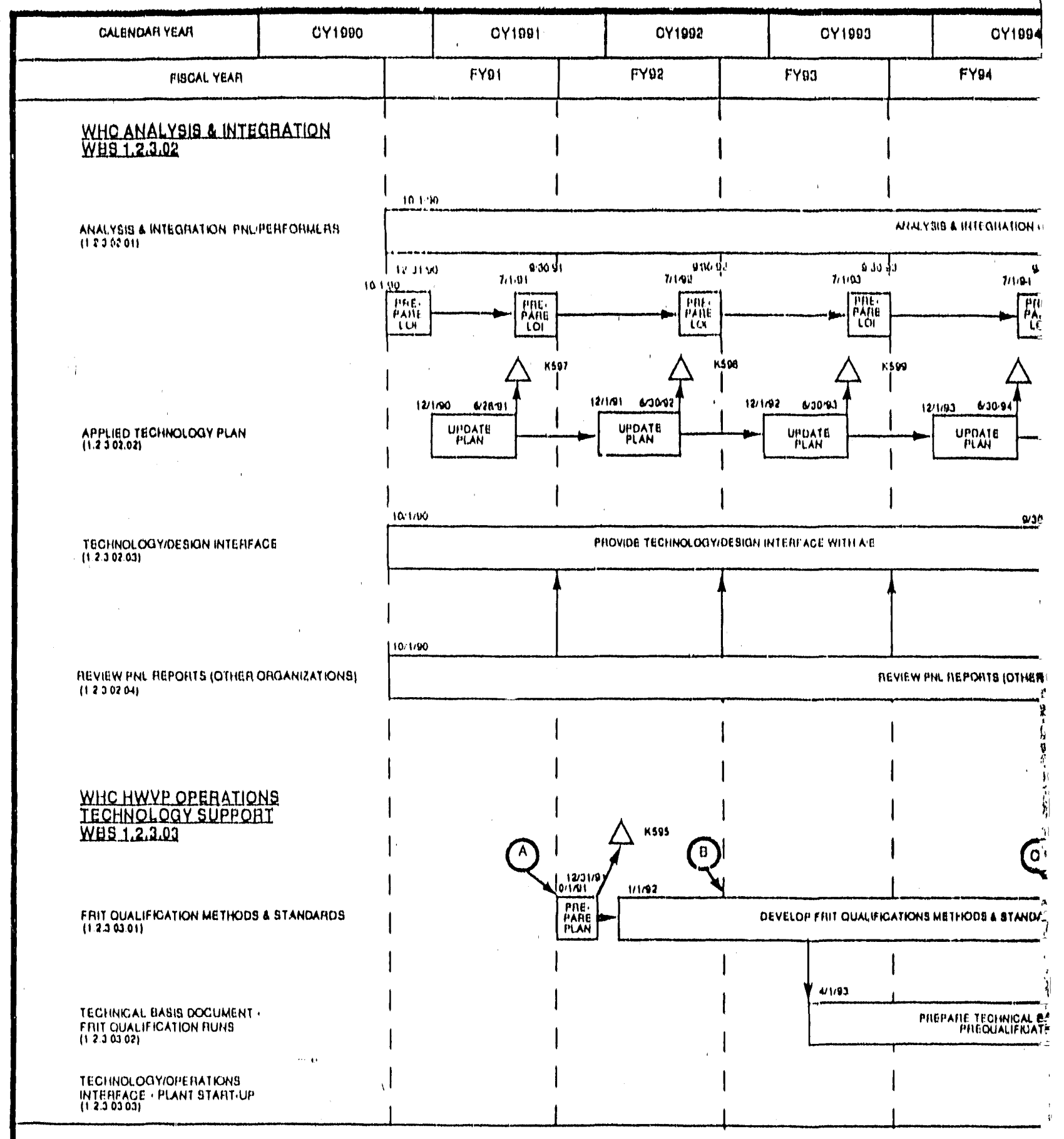

MLLESTONELISI

1,2,3.02 WHC ANALYSIS \& INTEGAATION

$K$ SOY ISSUE FISCAL YEAAI OI APPLIED TECHINOLOOY PLIN UPOATE $K$ SPA ISSUE FISCAL YEAHI D? AHPLLED TECHNOLOOY PLAN UPDAIE K SO ISQUE FIBCAL. YEAII OJ APPLIED TECHIOLOOY PLANUPOAIE $K$ EOO LSSULF FLSCAL YEAII WA APPLIED TECHNOLOOY PLAIT UPOATE $K$ BOI ISSUE FISCAI. YEALI OS APPLIED TECIINOLOOY PLAIN UPDATE $K$ 60\% SSUE FICAL YEAII DO APHLLEO TEOIINOLOCY PI.ANUPDAIE $K$ 2 $3.02 A$ ISSUE FISCAL YEAII O7 APPLIEO TECHNOLOGY PLAN UPDAIE
$K$ 2 J.02H ISSUE FISCAL YEAII OO APPLIEO TEOHNOLOGY PLAIN UIUATE
1.2,3.03 WHC HWVP OPEAATIONE K SOS COMPLETE PFIT OUALLFICATIC: K SOD COMPLETE FRIT CUALFICATIC: K SS2 ISBUE TEOHNICAL BASIS DOOL K SSG ISSUE THCHNICAL BASIS DOOLW 
Figure 11-1. Hanford Waste Vitriflcation Plan Technology Summary Schedule. (sheet 9 of: 13)

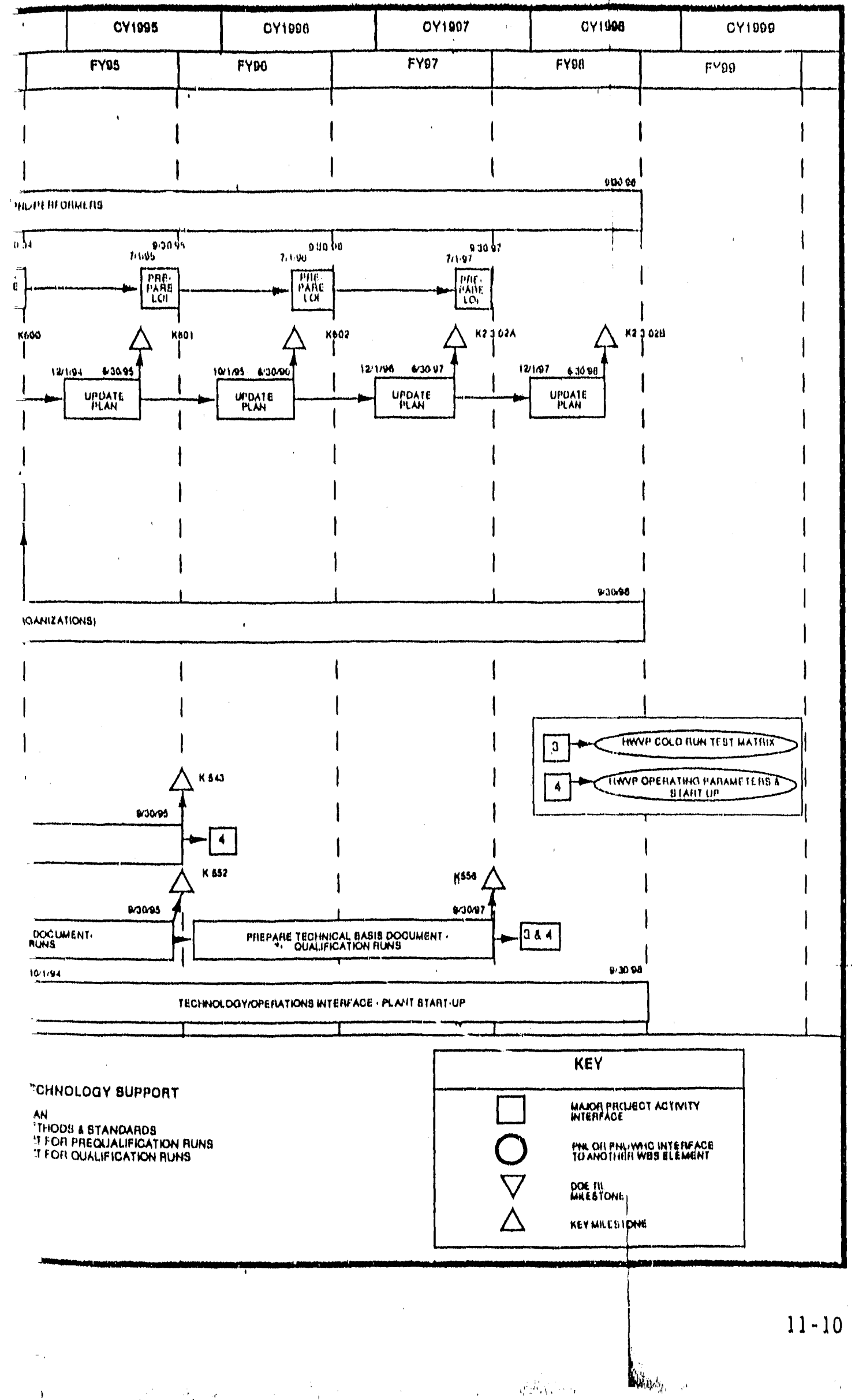




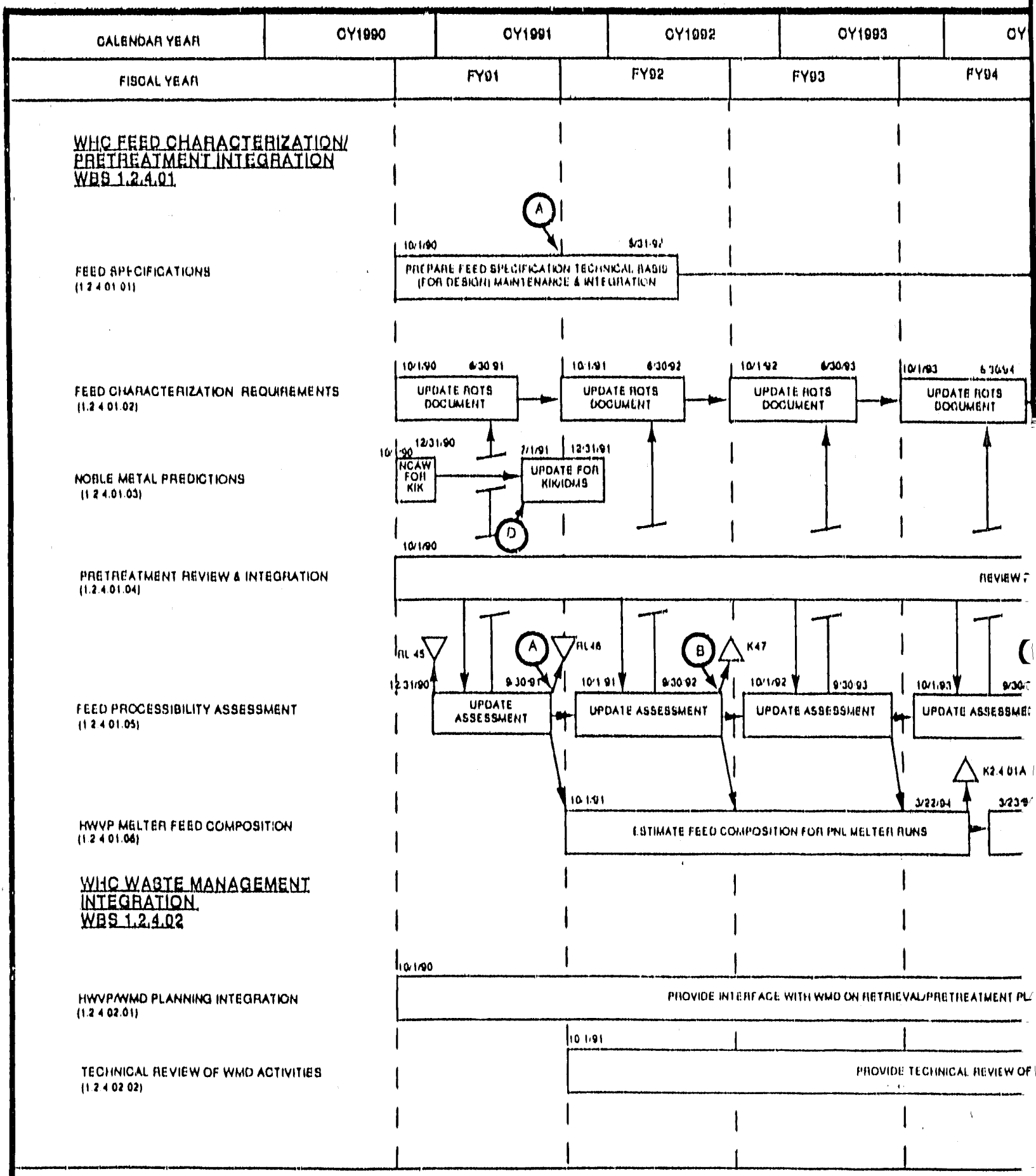

MILESTONELISI

F1. 45 ISSUE HWVP FEEO PROCE SSIEILITY ABSESSMENT HEPONI AL. AS ISSUE HWVP FEED PHOCERSILILIYY ASGE SSMENT UPUATE $K$ a7 ISSUE INVH FEED PROCESBIGLLITY ASSESSMENT UPDATE K 2.4.01A ISSUE ESTHUTEO NCAW MELTEA FEED COWEOSITION
K 2. 016 LSSUL: HWVP FEEO PROCHSSIOMLIT $K$ SOS ISSUE IWVP FEEO PFOCESSIBILIT

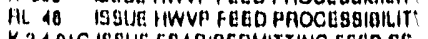
K 2.01C ISSUE FGARIPEFINITTWO FESD SF K2.4.010 ISSUE HWVP FEAO PROCESSIBILIT 


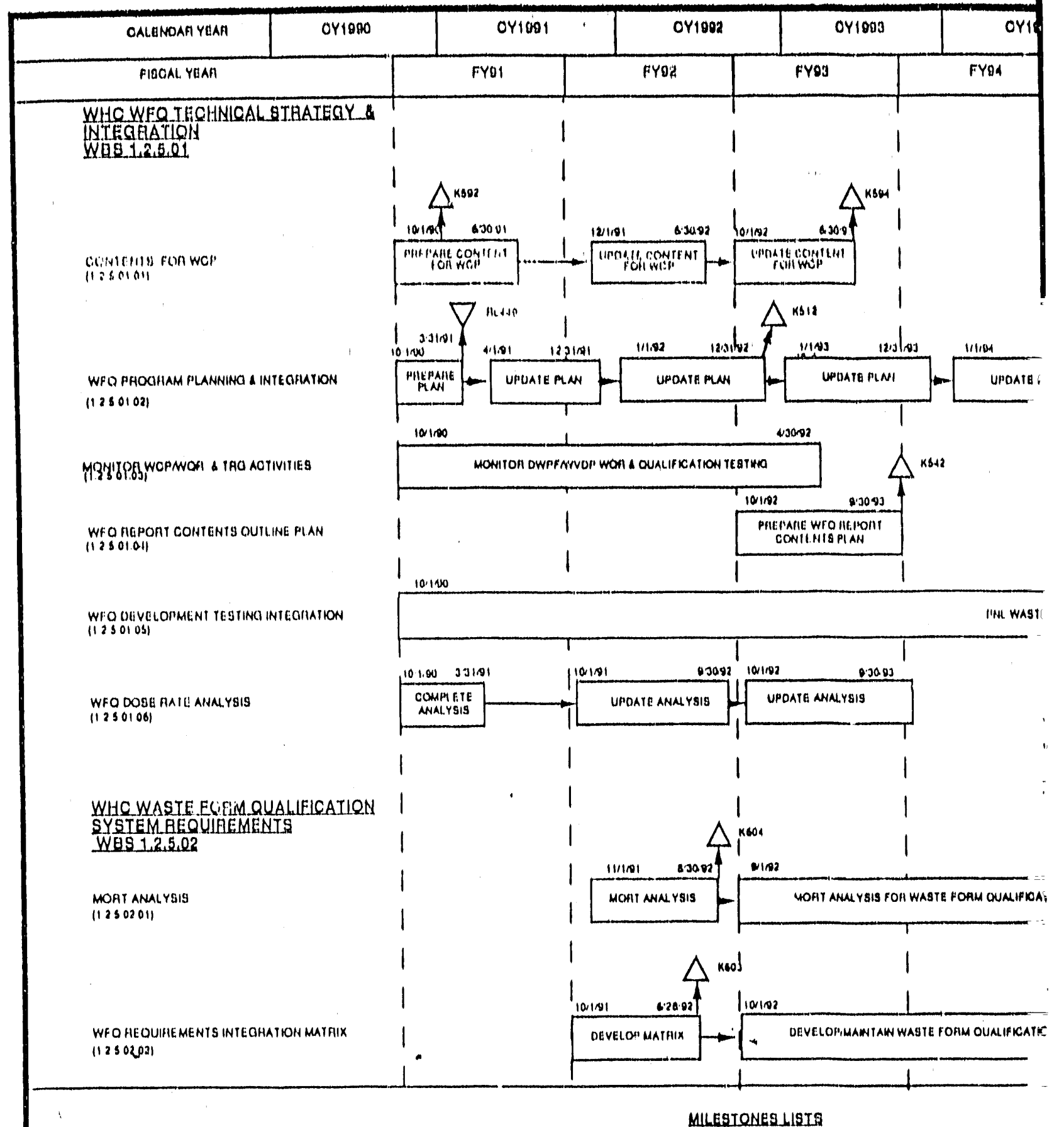

1,2.0.01 WHO WPO TECHNICAL STAATEQY INTEGATTION

$1.2 .6 .02 \div$

AL 40 ISSUE WFO PAOGRMM PLAN

$K$ S90 COMPLGTE CONTENTA PUN FOR WCP

$K$ KIT ISSUE WFO PROGALAI PLAN UPDATE

$k$ BOA OEFWE AEVISIONS TO CONTENTS PLAN FOA WCP

$K$ BA2 CONPLETE PLAN FOA WOH CONTENTS DEVELLOPMENT

$K$ S27 ISSUI: WFO PROCBRAM PLAN UPCATI

$K$ SAI HSSUE WFO PROGRAM PLAN UPDATE

MILESTONES LISTS 


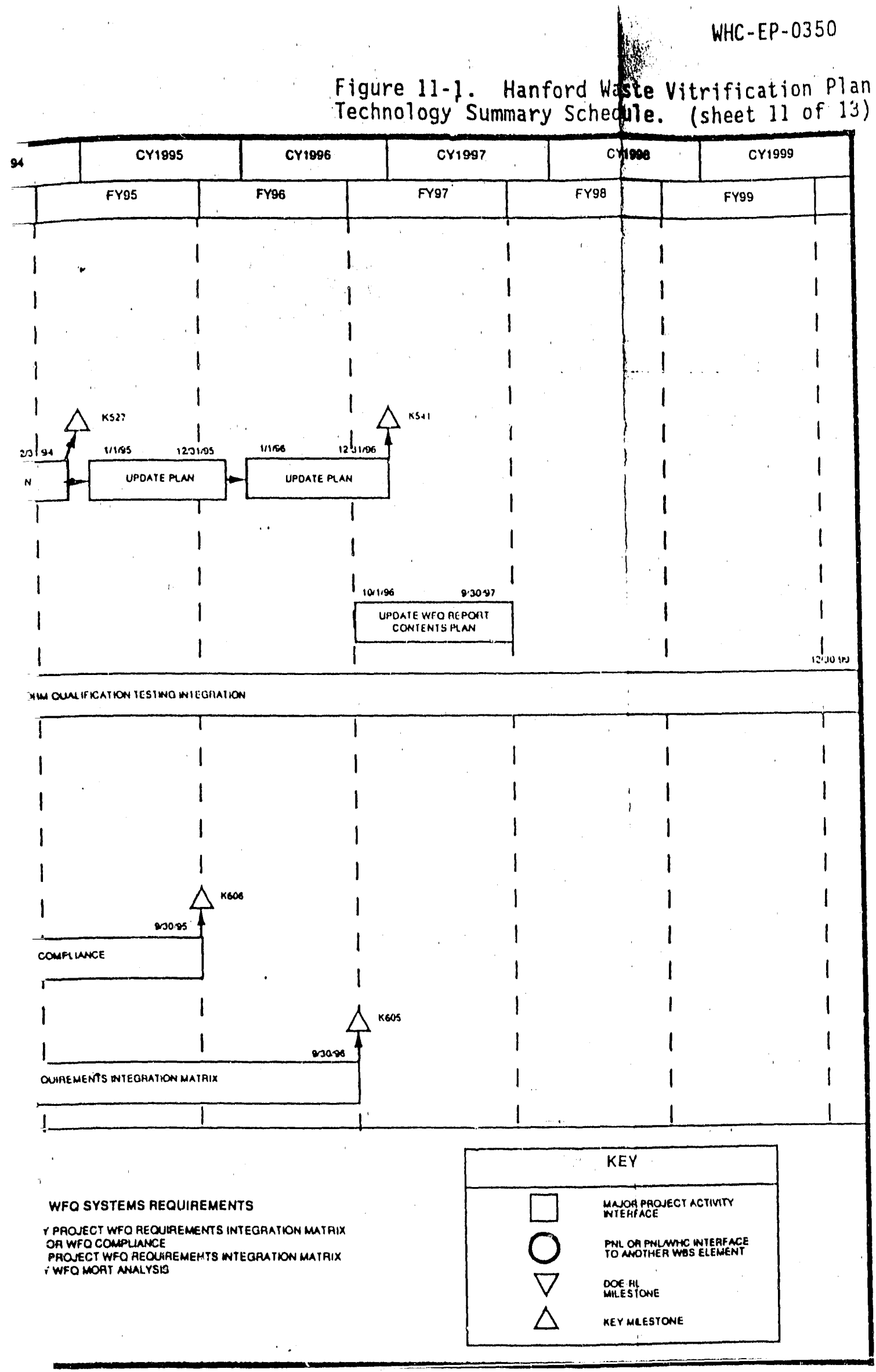




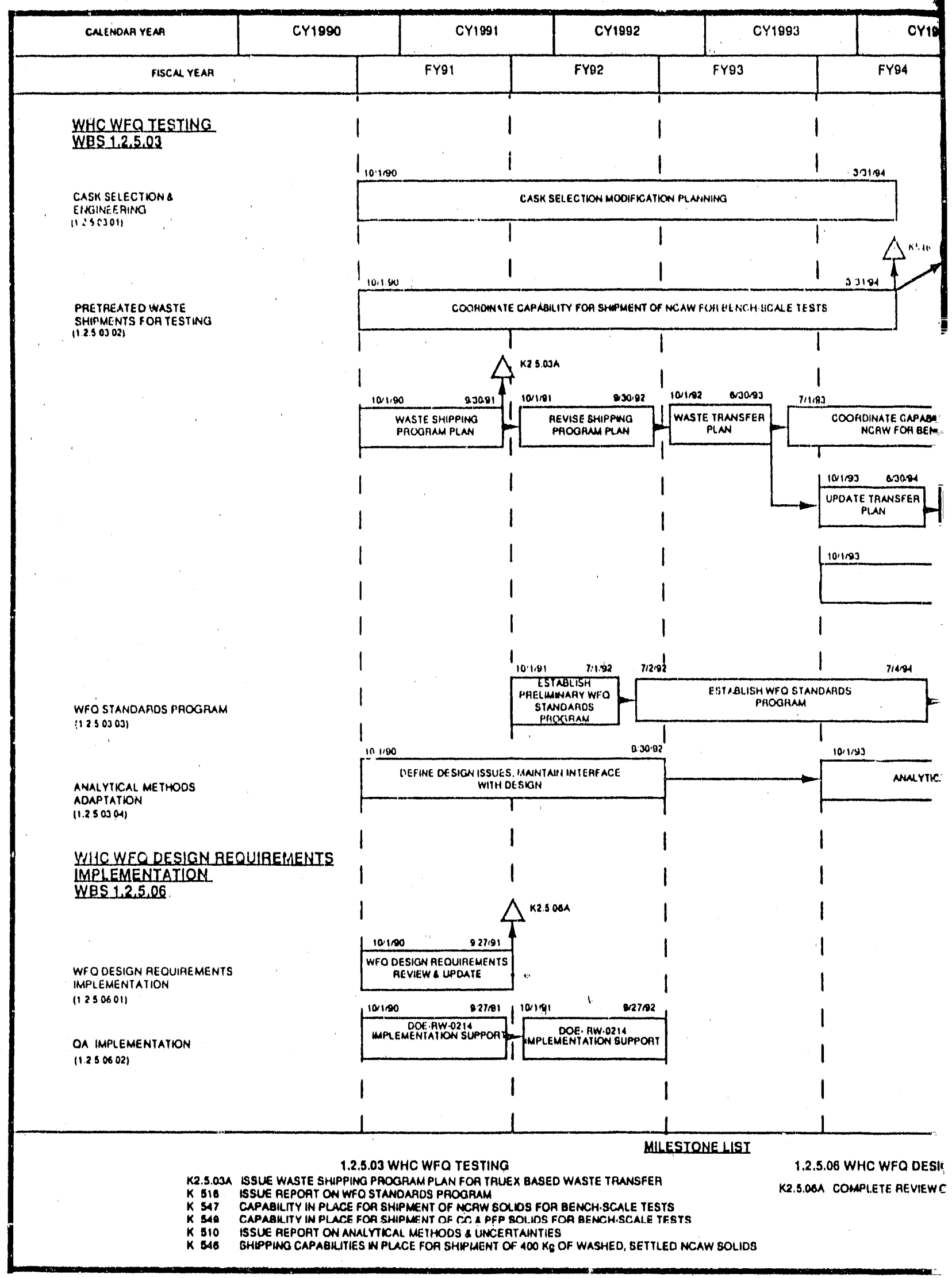




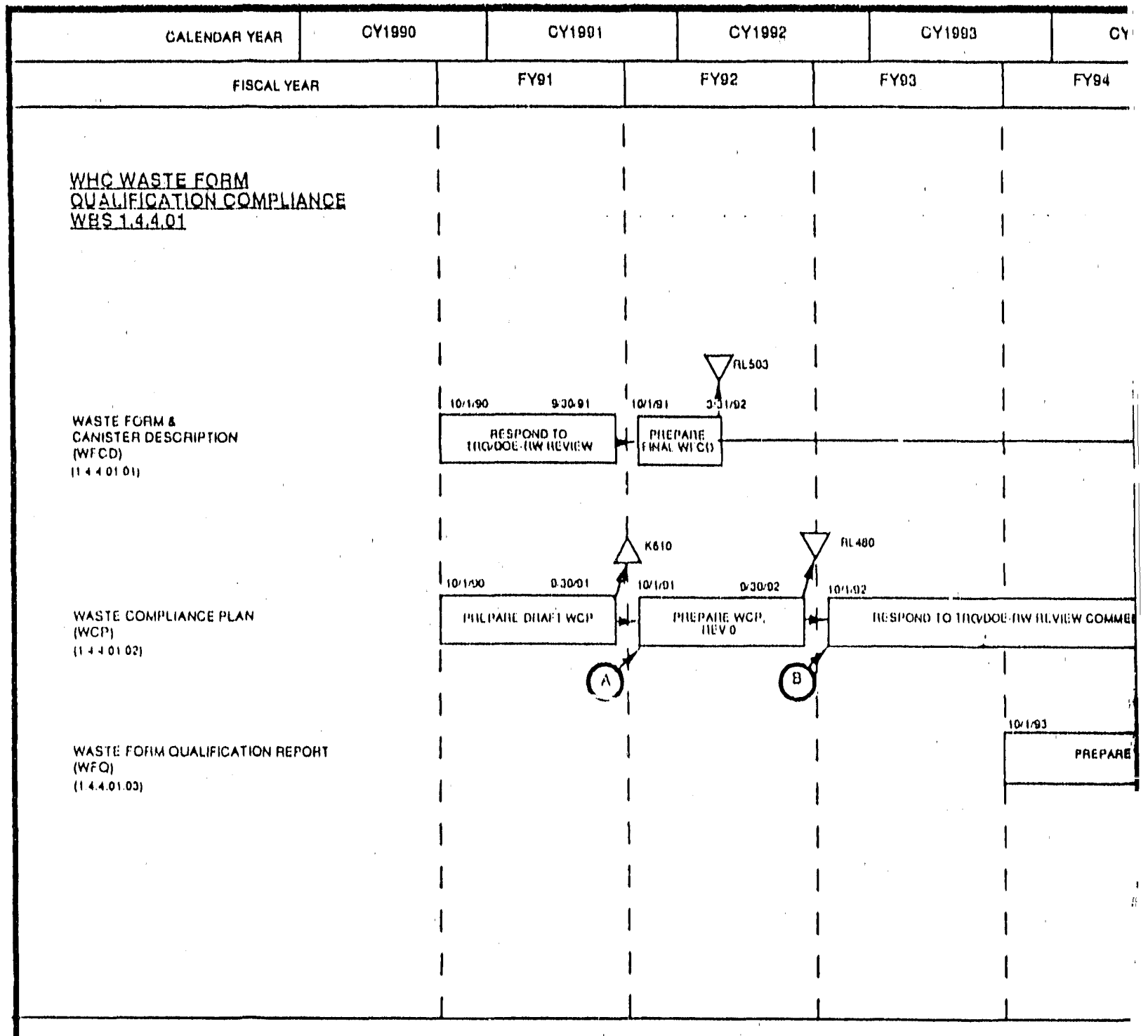

\section{MILESTONELISI}

K 610 DPAFT WASTE COMPLIANCE PLAN OUTLINE COMPLETE

HL. 503 ISSUE WASTE FOFIM \& CANISTEA DESCHIPIION DOCUMENI

RL 460 SUBMIT WASTE COMPLIANEE PLAN, AEV. O FOR TFIG AEVIEW

$K 22$ ISSUE WASTE COMPLIANCE PL.AN REFL.ECTINO THO AEVIEW COMMENT

$K$ 4.4.01A COMPLETE DFAFTS OF WFQ REPOAT RACICACES FOA CANISTEA

K 4.4.018 SUBMIT DAAFT WFO REPORT SECTION ON PAOCEESS CONTAOL FCA THO HEVIEW

K 4.4.01C COMPLETE OHAFTS OF WFO REPOAT PACKAGES ON CANISTEREO WAST: :DAM

$K$ 4.4.010 SUBMIT PFOCESS OUALIFICATION WFO REPOAT SECTIONS FOA TRG/FW HEVIEW 
Figure 11-1, Hanford Waste Vitrification Plan Technology Summary Schedule. (sheet 13 of 13)

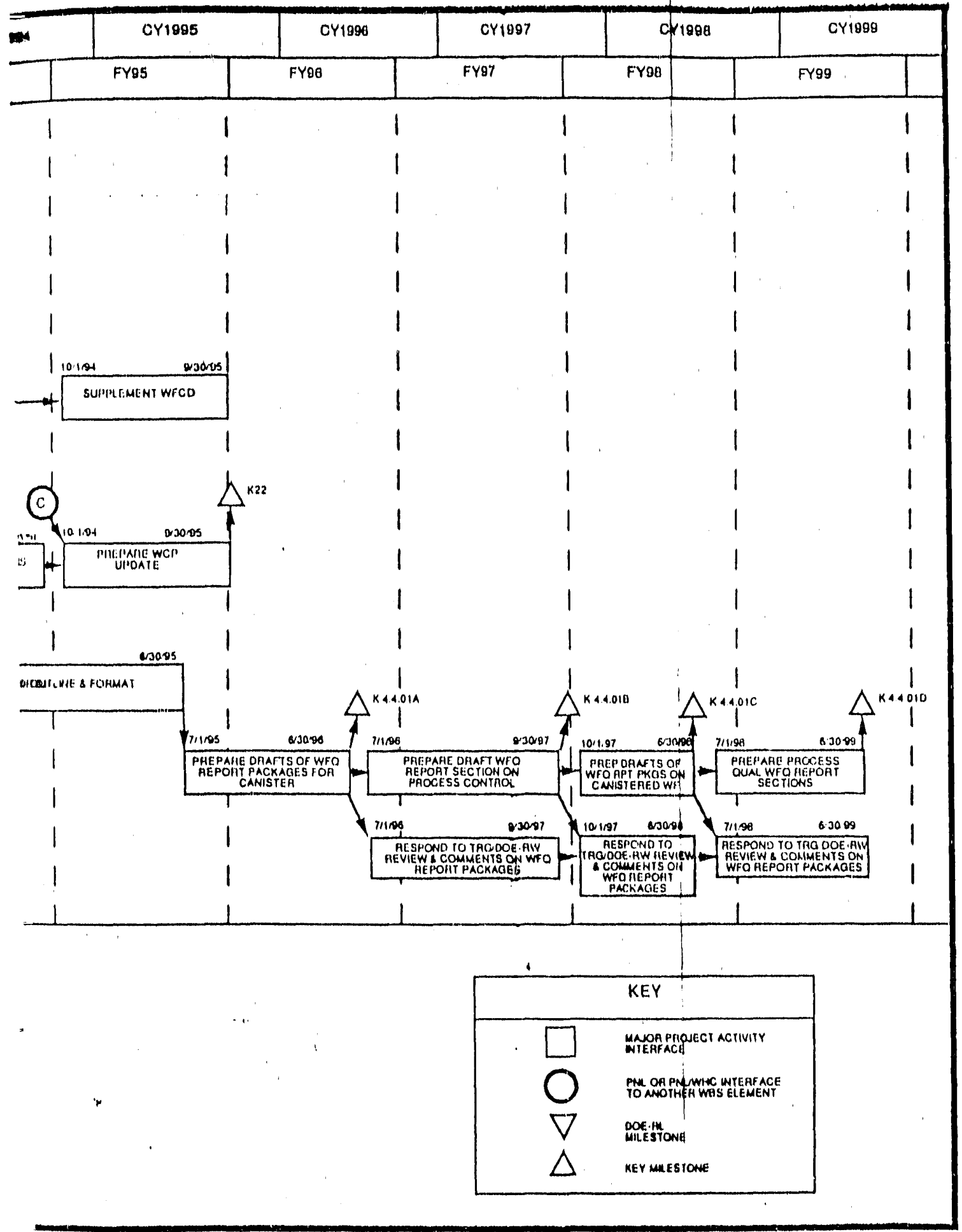


WHC-EP-0350

The 1.2.1 work element provides for the planning, collection, transfer, and management of technology derived from DWPF, WVDP, and vitriffcation programs in Japan, France, FRG, and the United Kingdom. The products of this work element are trip reports, debriefings, and input to the PNL LOIs when applicable.

The 1.2.2 work element includes all PNL applied technology described in this Plan. The majority of this work will be for glass and process development and process verification testing, product testing, and development of models for WFQ. Technical direction, coordination, review, and database control for PNL and other applied technology activities are included in the 1.2.3 element of the HWVP WBS. Also included in 1.2.3 are Westinghouse Hanford activities for analytical tracking system development, frit vendor qualification, and melter testing at DWPF. The WFQ Technology Definition element, 1.2.5, includes radioactive waste shipment support and analytical methods and stiandards tests.

The 1.2.4 element provides the integration and coordination of process technology and WFQ requirements with the WMD programs. This element provides HWV feed specifications and feed characterization requirements to other waste management organizations involved in waste pretreatment and tank characterization.

The summary level schedules for the HWVP Project Technology organization, including PNL Applied Technology, are shown in Figure 11-1. Key and DOE milestones and the interface of each task, major activity, and milestone with other Technology activities are shown on these summary schedules. Many of the tasks and milestones are interdependent and much of the work must be accomplished in the order shown to provide sufficient data for the WQR and HWVP readiness review and startup.

A detalled schedule showing various activities needed for each task is being prepared for FYs 1991 and FY 1992. These schedules will be used as the planning baseline for cost distribution and control. 


\subsection{REFERENCES}

Anantatmula, R. P., 1990, Hanford Site Environmental Restoration and Waste Management Technology Plan, WHC-EP-0212-1, Westinghouse Hanford Company, Richland, Washington.

ANSI, 1987, American National Standard for Leakage Tests on Packages for Shipment of Radioactive Materials, ANSI N14.5-1987. American National' Standards Institute, New York, New York.

Augustine, C., 1990, Double-She11 Tank Waste Disposal Integration Plan, Revision 1, WHC-EP-0229, Westinghouse Hanford Company, Richland, Washington.

Bates, S. 0., G. F. Piepe1, and J.W. Johnston, 1989, Leach Testing of Simulated Hanford Waste Vitrification Plant Reference Glass HW-39, PNL-6884, Pacific Northwest Laboratory, Richland, Washington.

CAA, 1977, Clean Air Act of 1977, Public Law 95-95, 91 Stat. 685 (42 USC 7401).

DOE, 1983, Defense Waste Management Plan, DDE/DP-0015, U.S. Department of Energy, Washington, D.C.

DOE, 1986, Quality Assurance, DOE Order 5700.6B, U.S. Department of Energy, Washington, D.C.

DOE, 1987, Final Environmental Impact Statement: Disposal of Hanford Defense High-Level, Transuranic, and Tank Wastes, Hanford Site, Richland, Washington, DOE/EIS-0113, U.S. Department of Energy, Washington, D.C.

DOE, 1988, Disposal of Hanford Defense High-Level, Transuranic, and Tank Wastes, Hanford Site, Richland, Washington; Record of Decision, Federal Register V.53 (72), p. 12449-12453.

DOE-OCRWM, 1986, Waste Acceptance Preliminary Specifications for the Defense Waste Processing Facility High-Level Waste Form, OGR/B-8, U.S. Department of Energy-Office of Civilian Radioactive Waste Management, Washington, D.C.

DOE-OCRWM, 1990, Quality Assurance Requirements Document for the Civilian Radioactive Waste Management Program, DOE/RW-0214, U.S. Department of Energy-Office of Civilian Radioactive Waste Management, Washington, D.C.

DOE-RL, 1983, Quality Assurance, DOE-RL Order 5700.1A, U.S. Department of Energy, Richland, Washington.

DOE-RL, 1989a, Hanford Site Waste Management P1an, DOE/RL-89-32, U.S. Department of Energy, Richland, Washington.

DOE-RL, 1989b, Environmental Restoration and Waste Management Site-Specific Plan for the Richland Operations Office: Detailed Information, DOE-RL 89-10, U.S. Department of Energy, Richland, Washington. 
DOE-RL, 1989c, Project Management system, DOE-RL Order 4700.1, U.S. Departiment of Energy, Richland, Washington.

Goles, R. W. and R. K. Nakaoka, 1990, Hanford Waste Vitrification Program Pilot-Scale Ceramic Melter Test 23, PNL-7142., Pactfic Northwest Laboratory, Richland, Washington.

Kruger, 0. L., 1989, Hanford Waste Vitrification Plant Applied Technology Plan, WHC-EP-0224, Westinghouse Hanford Company, Richland, Washingtion.

Mitche11, D. E. and J. L. Nelson, 1988, Hanford Waste Vitrification Plant Preliminary Description of Waste Form and Canister - IY 1988 Update, WHC-EP-0008, Reviston 1, Westinghouse Hanford Company, Richland, Washington.

Nelson, J. L., 1988, Hanford Waste Vitrification Plant Preliminary Waste Form Qualification Plan - FY 1988 Update, WHC-EP-0045, Revision 1, Westinghouse Hanford Company, Richland, Washington.

PNL, 1989, Quality Assurance Manua7, PNL-MA-70, Paciftc Northwest Laboratory, Richland, Washington.

Powers, H. G., 1989, Hanford Waste Management Technology Plan, Calendar Year 1988, WHC-EP-0212, Westinghouse Hanford Company, Rtchland, Washington. 


\subsection{GLOSSARY}

\section{ABBREVIATIONS, ACRONYMS, AND INITIALISMS}

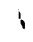

1

A/E
AP
CC
CDC
CENRTC
DCS
DF
DOE
DOE. RL
DOE-.RW
DST
DWPF
EIS
ESM
FIUON
FRG
FSAR
FY
GTAW
HBCM
HDW
HEME
HEPA
HSERWMTP
HLW
HP
HSWMP
HWVP
ICP.MS
KFK
IDMS
LFCM
LLW
LOI
MBM
MFT
MIS
MOG
N/A
NCAW
NCRW
NRC
OTP
PCCS
PCT
PFP
PMP
PNL

architect engineer

assessment point

complexant concentrate

cantster decontamination chamber

capttal equipment not related to construction

Distributed Control System

decontamination factor.

U.S. Department of Energy

U.S. Department of Energy. Richland Operations Office

U.S. Department of Energy-Radloact Ive Waste

double-shell tank

Defense Waste Processing Factlity

Environmental Impact Statement

engineering-scale melter

Fluor Dantel, Inc.

Federal Republtc of Germany

Final Safety Analysis Report

fiscal year

gas tungsten arc welding

high-bay ceramic melter

Hanford defense waste

high-efficiency mist eliminator

high-effictency particulate air

Hanford site Environmental Restoration and Waste Management

Technology Plan

high-level waste

hold point

Hanford Site Waste Management Plan

Hanford Waste Vitrification Plant

inductively coupled plasma-mass spectrograph

Kernsforschungszentrum Karlsruhe

Integrated DWPF Melter System

liquid-fed ceramic melter

low-level waste

letter of instruction

mass balance model

melter feed tank

Management Information System

melter offgas

not applicable

neutralized current acid waste

neutralized cladding removal waste

U.S. Nuclear Regulatory Commission

operations test procedure

product composition control system

product consistency test

Plutonium Fintshing Plant

Project Management Plan

Pactfic Northwest Laboratory 


\begin{tabular}{|c|c|}
\hline $\begin{array}{l}\text { PSCM } \\
\text { PUREX } \\
\text { QA } \\
\text { OCR } \\
\text { RWCT } \\
\text { SBS } \\
\text { SETF } \\
\text { SME } \\
\text { SRAT } \\
\text { SRS } \\
\text { TOC } \\
\text { TRG } \\
\text { TRU } \\
\text { TRUEX } \\
\text { TTT } \\
\text { VCC } \\
\text { WAS } \\
\text { WAPS } \\
\text { WBS } \\
\text { WCP } \\
\text { WeSt 1nghouse } \\
\text { Hanford } \\
\text { WFQ } \\
\text { WMD } \\
\text { WQR } \\
\text { WSM } \\
\text { WVDP }\end{array}$ & 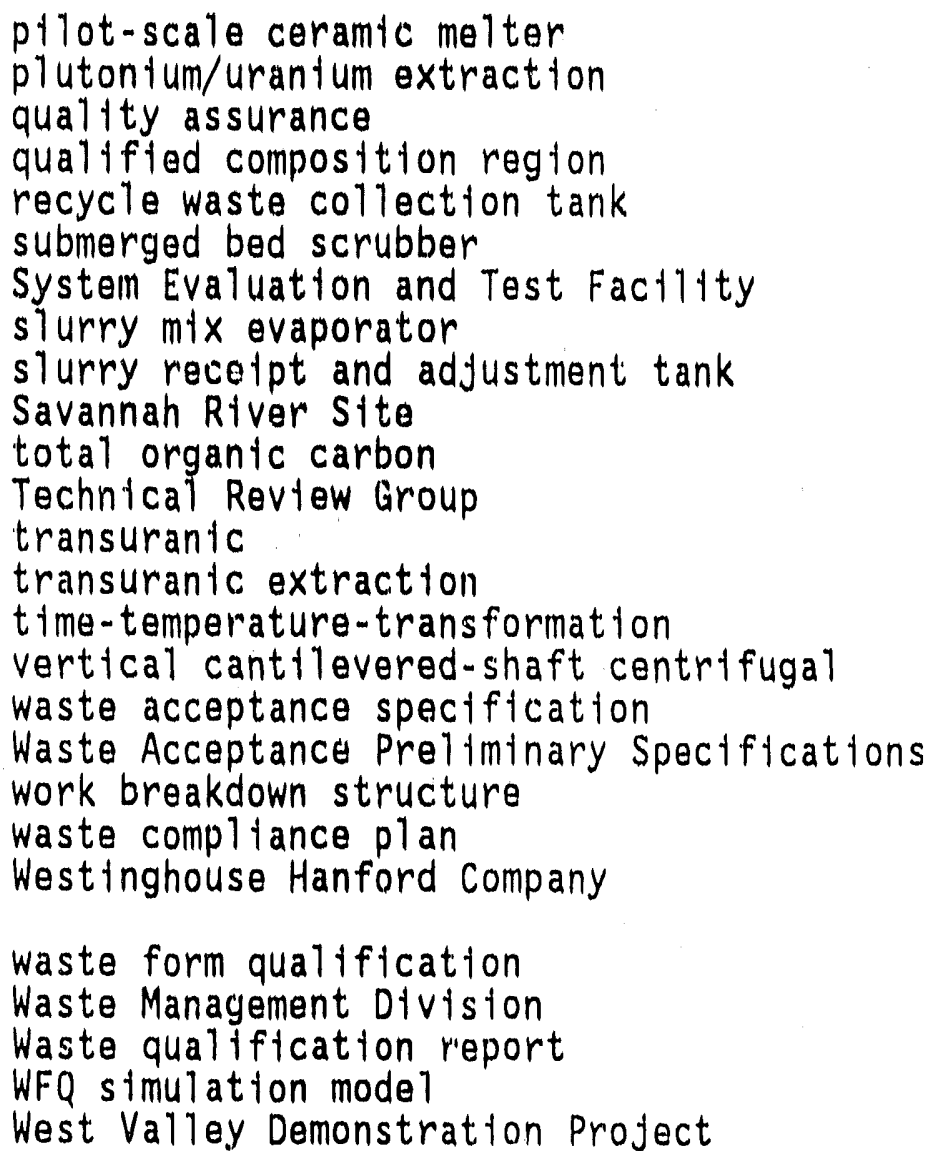 \\
\hline
\end{tabular}



